Prepared in cooperation with the U.S. Army Corps of Engineers Portland District and Northwest Association of Networked Ocean Observing Systems

\title{
Observations of Coastal Change and Numerical Modeling of Sediment-Transport Pathways at the Mouth of the Columbia River and its Adjacent Littoral Cell
}

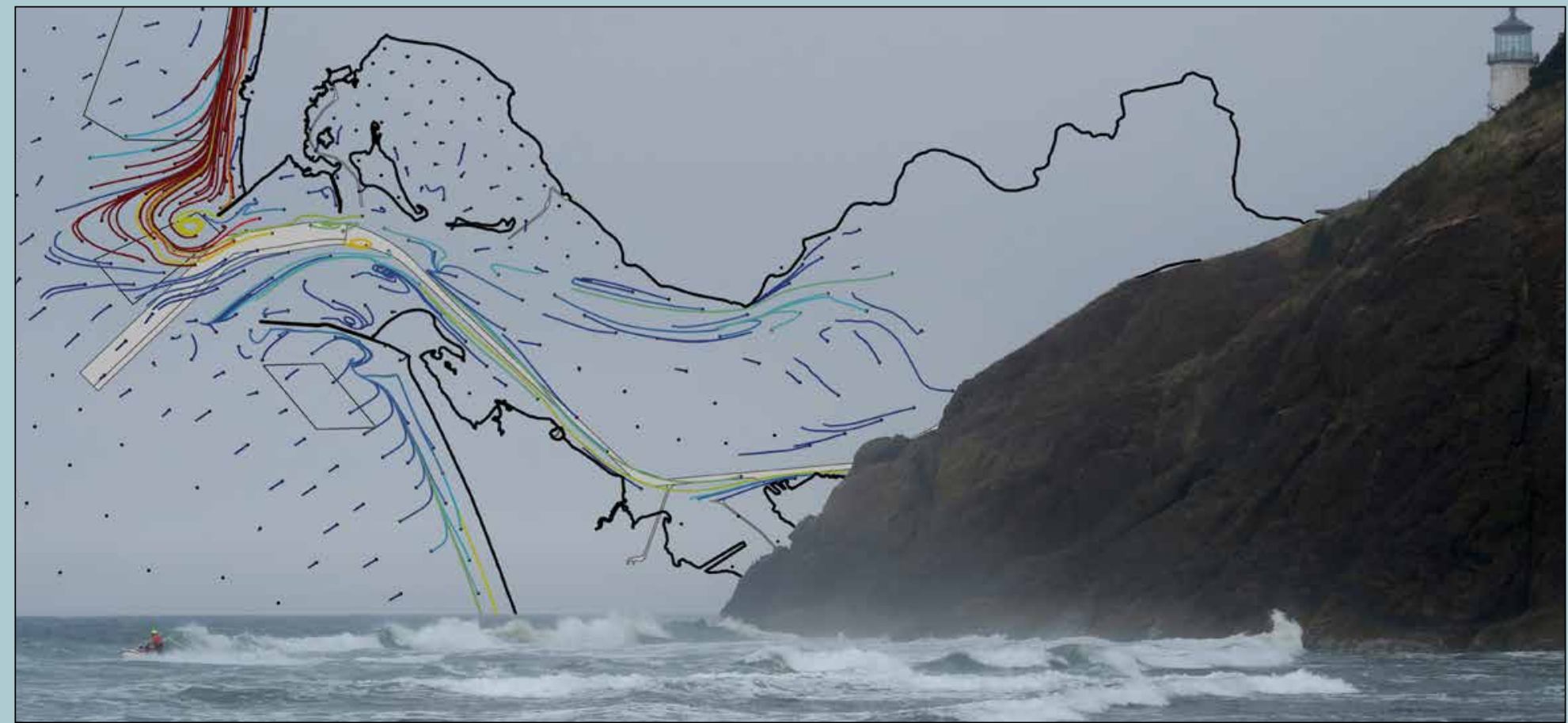

Open-File Report 2020-1045 
Cover. Photograph of North Head Lighthouse, Washington, overlain by tracing of shoreline (black lines) and an example of model output (colored lines). Photograph by Andrew Stevens, August 31, 2016. 


\section{Observations of Coastal Change and Numerical Modeling of Sediment-Transport Pathways at the Mouth of the Columbia River and its Adjacent Littoral Cell}

By Andrew W. Stevens, Edwin Elias, Stuart Pearson, George M. Kaminsky, Peter R. Ruggiero, Heather M. Weiner, and Guy R. Gelfenbaum

Prepared in cooperation with the U.S. Army Corps of Engineers Portland District and Northwest Association of Networked Ocean Observing Systems

Open-File Report 2020-1045 


\title{
U.S. Department of the Interior DAVID BERNHARDT, Secretary
}

\author{
U.S. Geological Survey \\ James F. Reilly II, Director
}

\section{U.S. Geological Survey, Reston, Virginia: 2020}

For more information on the USGS - the Federal source for science about the Earth, its natural and living resources, natural hazards, and the environment-visit https://www.usgs.gov or call 1-888-ASK-USGS.

For an overview of USGS information products, including maps, imagery, and publications, visit https://store.usgs.gov.

Any use of trade, firm, or product names is for descriptive purposes only and does not imply endorsement by the U.S. Government.

Although this information product, for the most part, is in the public domain, it also may contain copyrighted materials as noted in the text. Permission to reproduce copyrighted items must be secured from the copyright owner.

\section{Suggested citation:}

Stevens, A.W., Elias, E., Pearson, S., Kaminsky, G.M., Ruggiero, P.R., Weiner, H.M., and Gelfenbaum, G.R., 2020, Observations of coastal change and numerical modeling of sediment-transport pathways at the mouth of the Columbia River and its adjacent littoral cell: U.S. Geological Survey Open-File Report 2020-1045, 82 p., https://doi.org//10.3133/ofr20201045.

Associated data for this publication:

Stevens, A.W., Weiner, H.M., Ruggiero, P., Kaminsky, G.M., and Gelfenbaum, G.R., 2019, Beach topography and nearshore bathymetry of the Columbia River littoral cell, Washington and Oregon (ver. 2.0, November 2019): U.S. Geological Survey data release, https://doi.org//10.5066/P9W15JX8. 


\section{Acknowledgments}

Funding for this study was provided by the U.S. Army Corps of Engineers (USACE) Portland District (in support of the Military Interdepartmental Purchase Request \#W660KZ80758076), U.S. Geological Survey (USGS) Coastal and Marine Hazards and Resources Program, and the Northwest Association of Networked Ocean Observing Systems (NANOOS).

We thank the large group of coastal scientists, known as the "nearshore all-stars," that participated in the bathymetric and topographic surveys. In particular, we acknowledge the efforts of Jeff Wood, Dylan Anderson, Katy Serafin, Nick Cohn, and Paige Hovenga, of Oregon State University; Diana McCandless and Amanda Hacking, of Washington State Department of Ecology; and Tim Elfers, Cordell Johnson, and Jackson Currie of USGS.

We thank Lee Faraola of Faraola Brothers Inc., whose mechanical expertise has been essential in keeping the USGS personal watercraft operational during the past few years.

We thank Rod Moritz, James McMillan, and Jarod Norton from the Portland District USACE for overall project coordination. Reviews by Nick Cohn and Sean Vitousek greatly improved an earlier version of this report. 


\section{Contents}

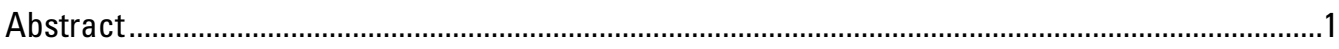

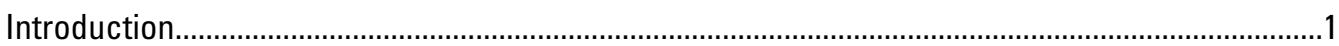

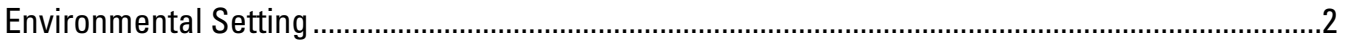

Task 1 - Observations of Coastal Change ....................................................................................

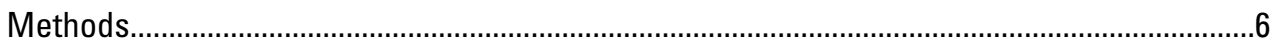

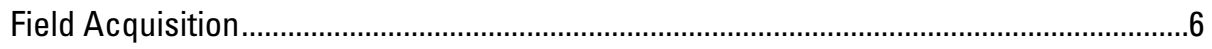

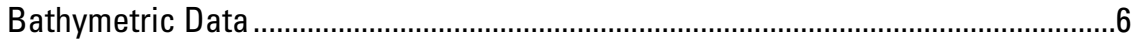

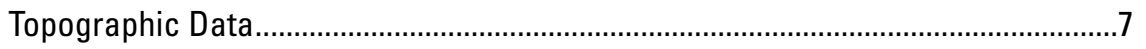

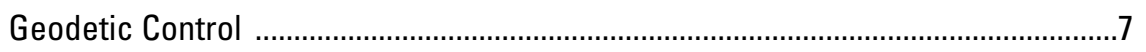

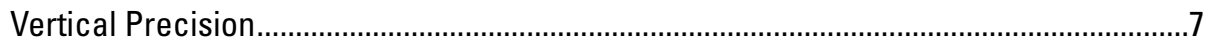

Volume Change and Uncertainty Analysis .................................................................

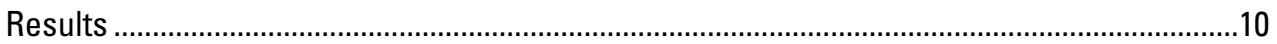

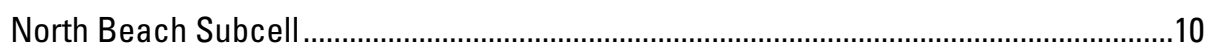

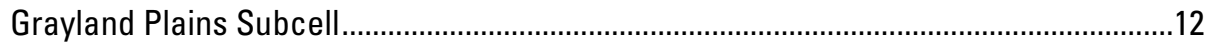

Long Beach Subcell ...................................................................................................

Clatsop Plains Subcell ................................................................................................

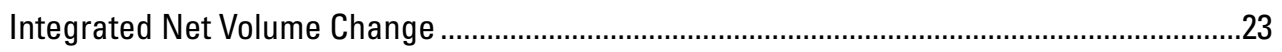

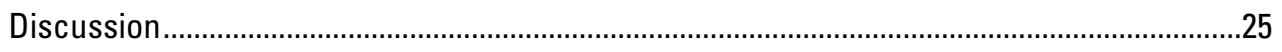

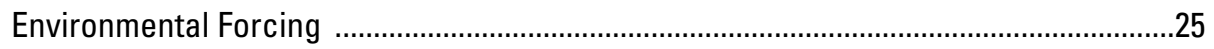

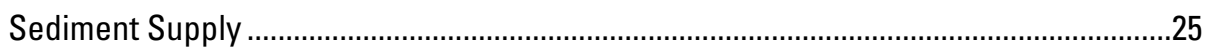

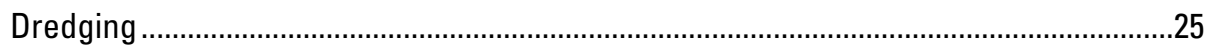

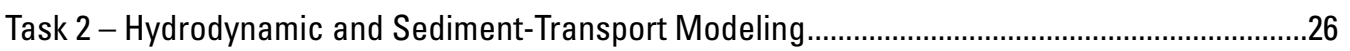

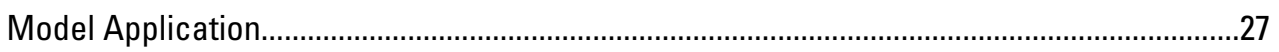

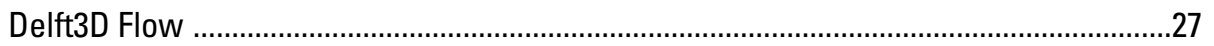

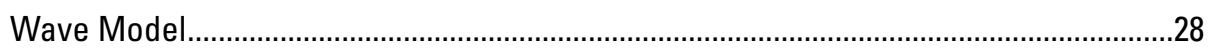

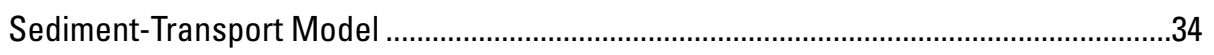

Sediment Pathways Interactive Visualization Tool (SPIT) .....................................................

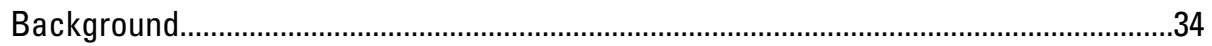

Application of SPIT to the Mouth of the Columbia River ................................................34

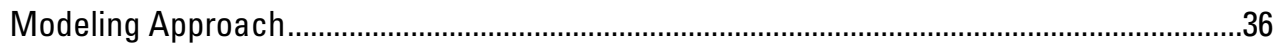

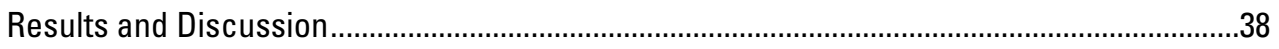

Method 1-Event Time Scales ................................................................................38

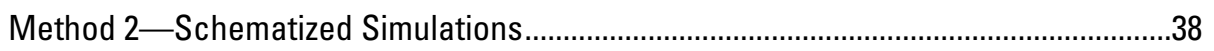

Low-River-Discharge Conditions ........................................................................42

High-River-Discharge Conditions.....................................................................42

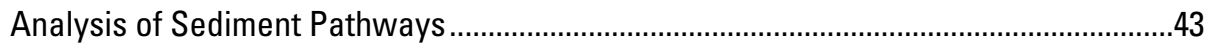

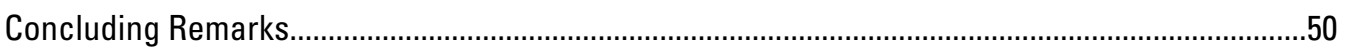

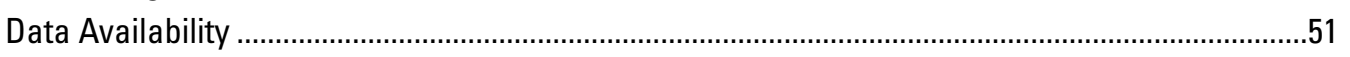

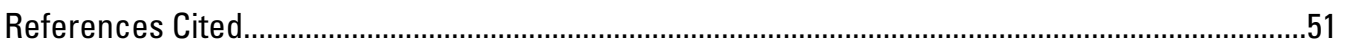

Appendix 1. Coverage Maps, Environmental Conditions, and Water-Column Properties During

Bathymetric and Topographic Surveys ...........................................................................55

Appendix 2. Wave Heights, Mean Sediment-Transport Fluxes, and Sediment-Transport

Pathways for Schematized Wave-Climate Simulations.......................................................73 


\section{Figures}

1. Map of Columbia River littoral cell, showing locations of its subcells, major estuary entrances, and natural headlands that represent its northern and southern extents, respectively, also shown are locations of survey lines, geodetic benchmarks, wave buoys, water level gauges, instrumented tripods, and stream gauges............................2

2. Maps of Columbia River estuary and mouth of Columbia River, showing locations of major engineering structures; active dredge-placement sites, North Head study area, maintained federal navigation channels, survey lines, geodetic benchmarks, wave buoys, water level gauges, instrumented tripods, and stream gauges..............................

3. Time-series plots of wave heights, cumulative along-shore wave-energy flux, monthly mean sea level observed at Westport, Wash., and river discharge of Columbia River measured at Bonneville Dam and Willamette River at Salem, Ore.

4. Field equipment used to collect bathymetric and topographic data ................................6

5. Example analysis of replicate profile to estimate vertical uncertainty in bathymetric measurements..

6. Maps showing cumulative net volume changes for entire profiles in 2015, 2016, 2017, 2018, and 2019.

7. Map showing cumulative elevation changes

along North Beach subcell between 2014 and 2019; also shown are cumulative volume changes for beach, nearshore, and entire profiles during same time period

8. Map showing cumulative elevation changes between 2014 and 2019 for Ocean City region within North Beach subcell; example profile showing changes in beach and nearshore morphology along survey line 082; time-series plot of volume changes calculated for Ocean City region

9. Map showing cumulative elevation changes between 2014 and 2019 for Ocean Shores region within North Beach subcell; example profile showing changes in beach and nearshore morphology along survey line 010; and time-series plot of volume changes calculated for Ocean Shores region.

10. Map showing cumulative elevation changes along Grayland Plains subcell between 2014 and 2019; also shown are cumulative volume changes for beach, nearshore, and entire profiles during same time period.

11. Map showing cumulative elevation changes between 2014 and 2019 for Westport region within Grayland Plains subcell; example profile showing changes in beach and nearshore morphology along survey line 090; and time-series plot of volume changes calculated for Westport region

12. Map showing cumulative elevation changes between 2014 and 2019 for Grayland region within Grayland Plains subcell; example profile showing changes in beach and nearshore morphology along survey line 035; and time-series plot of volume changes calculated for Grayland region

13. Map showing cumulative elevation changes along Long Beach subcell between 2014 and 2019; also shown are cumulative volume changes for beach, nearshore, and entire profiles during same time period

14. Map showing cumulative elevation changes between 2014 and 2019 for Oysterville region within Long Beach subcell; example profile showing changes in beach and nearshore morphology along survey line 069; and time-series plot of volume changes calculated for Oysterville region 
15. Map showing cumulative elevation changes between 2014 and 2019 for Benson Beach and North Head regions within Long Beach subcell; example profile $s$ howing changes in beach and nearshore morphology along survey line 198; and time-series plot of volume changes calculated for North Head region.

16. Map showing cumulative elevation changes between 2014 and 2019 for Benson Beach and North Head regions within Long Beach subcell; example profile showing changes in beach and nearshore morphology along survey line 214; and time-series plot of volume changes calculated for Benson Beach region.

17. Map showing cumulative elevation changes along Clatsop Plains subcell between 2014 and 2019; also shown are cumulative volume changes for beach, nearshore, and entire profiles during same time period.

18. Map showing cumulative elevation changes between 2014 and 2019 for South Jetty region within Clatsop Plains subcell; example profile showing changes in beach and nearshore morphology along survey line 037; and time-series plot of volume changes calculated for South Jetty region.

19. Map showing cumulative elevation changes between 2014 and 2019 for Camp Rilea region within Clatsop Plains subcell; example profile showing changes in beach and nearshore morphology along survey line 090; and time-series plot of volume changes calculated for Camp Rilea region

20. Integrated cumulative net volume changes in 2015, 2016, 2017, 2018, and 2019 for each region having intensive sampling; map shows locations of intensive sampling regions within each subcell; and time-series plots show integrated net volume changes for regions within North Beach, Grayland Plains, Long Beach, and Clatsop Plains subcells

21. Schematic representation of Delft3D modeling system

22. Map showing hydrodynamic and wave model grids used to simulate sediment transport in Columbia River estuary and at mouth of Columbia River; also; hydrodynamic model grids for Columbia River estuary and mouth of Columbia River

23. Modeled sensitivity of simulated water levels to variations in bed friction...

24. Comparison of measured and modeled current speeds and directions at West Tripod Site in 4-day time period during spring tides.

25. Comparison of modeled and measured water levels, current speeds, current directions, and salinity near seabed at West Tripod Site in same 4-day time period during spring tides as in figure 24 .

26. Time-series plots of modeled and measured wind speed, wind direction, significant wave height, peak wave period, and wave direction between 0ctober 18 and November 18, 2010 .

27. Comparison of modeled and measured wave parameters between 0ctober 18 and November 18, 2010 .

28. Maps showing Sediment Pathways Interactive visualization Tool (SPIT) visualizations of Lagrangian sediment-transport pathways showing sediment vector fields, streamlines representing vector fields, initial positions of sediment sources, and sediment pathways derived from SPIT analysis

29. Flow chart showing modeling approaches applied during this study .............................36

30. Sediment-transport dynamics under varying wave- and tide-forcing conditions ..........39

31. Sediment-transport dynamics under varying wave- and tide-forcing conditions after pilot placement of dredged material within North Head study area. 
32. Time-series plots of water levels and significant wave heights, bed-shear stress, and sediment-transport flux for 72 days (between September 20 and

December 1, 2018) after pilot placement of dredged material within North Head study area...

33. Maps showing annually averaged sediment-transport fluxes that are based on schematized model simulations during low fluvial-discharge scenarios; sedimenttransport vectors for simulations forced with tides and fluvial discharge alone and with tides, fluvial discharge, and waves.

34. Maps showing annually averaged sediment-transport fluxes that are based on schematized model simulations during high fluvial-discharge scenarios; sedimenttransport vectors (black arrows) are provided for simulations forced with tides and fluvial discharge alone and with tides, fluvial discharge, and waves

35. Maps showing sediment-transport pathways derived from application of Sediment Pathways Interactive visualization Tool (SPIT) to schematized model simulations using low-river-discharge conditions and constant wave forcing

36. Maps showing sediment-transport pathways derived from application of Sediment Pathways Interactive visualization Tool (SPIT) to schematized model simulations using high-river-discharge conditions and constant wave forcing...

37. Maps showing sediment-transport pathways calculated for various sedimentsource locations and polygons of interest for low-river-discharge scenario; all 500 sources and 19 wave classes originating from within North Head study area; sources and wave classes for pathways that interact with Benson Beach; and sources and wave classes for pathways that interact with navigational channel.........48

38. Probabilities of sediment-transport-pathway interactions between each source region and Benson Beach during low-river-discharge conditions.

39. Probabilities of sediment-transport-pathway interactions between each source region and navigation channel during low-river-discharge conditions

A1. Maps showing locations of bathymetric- and topographic-survey lines, sound-velocity measurements derived from Conductivity Temperature Depth casts, and benchmarks used for geodetic control from 2014 surveys along Columbia River littoral cell.

A2. Time-series plots of water levels, wave heights, wave periods, and wave directions during 2014 bathymetric and topographic surveys of Columbia River littoral cell

A3. Map showing locations of Conductivity Temperature Depth casts collected during 2014 bathymetric surveys

A4. Maps showing locations of bathymetric- and topographic-survey lines, soundvelocity measurements derived from Conductivity Temperature Depth casts, and benchmarks used for geodetic control from 2015 surveys along Columbia River littoral cell.

A5. Time-series plots of water levels, wave heights, wave periods, and wave directions during 2015 bathymetric and topographic surveys of Columbia River littoral cell ..........59

A6. Map showing locations of Conductivity Temperature Depth casts collected during 2015 bathymetric surveys

A7. Maps showing locations of bathymetric- and topographic-survey lines, soundvelocity measurements derived from Conductivity Temperature Depth casts, and benchmarks used for geodetic control from 2016 surveys along Columbia River littoral cell

A8. Time-series plots of water levels, wave heights, wave periods, and wave directions during 2016 bathymetric and topographic surveys of Columbia River littoral cell ...... 
A9. Map showing locations of Conductivity Temperature Depth casts collected during 2016 bathymetric surveys

A10. Maps showing locations of bathymetric- and topographic-survey lines, soundvelocity measurements derived from Conductivity Temperature Depth casts, and benchmarks used for geodetic control from 2017 surveys along Columbia River littoral cell.

A11. Time-series plots of water levels, wave heights, wave periods, and wave directions during 2017 bathymetric and topographic surveys of Columbia River littoral cell 65

A12. Map showing locations of Conductivity Temperature Depth casts collected during 2017 bathymetric surveys...

A13. Maps showing locations of bathymetric- and topographic-survey lines, soundvelocity measurements derived from Conductivity Temperature Depth casts, and benchmarks used for geodetic control from 2018 surveys along Columbia River littoral cell.

A14. Time-series plots of water levels, wave heights, wave periods, and wave directions during 2018 bathymetric and topographic surveys of Columbia River littoral cell.

A15. Map showing locations of Conductivity Temperature Depth casts collected during 2018 bathymetric surveys

A16. Maps showing locations of bathymetric- and topographic-survey lines, soundvelocity measurements derived from Conductivity Temperature Depth casts, and benchmarks used for geodetic control from 2019 surveys along Columbia River littoral cell.

A17. Time-series plots of water levels, wave heights, wave periods, and wave directions during 2019 bathymetric and topographic surveys of Columbia River littoral cell ..........71

A18. Map showing locations of Conductivity Temperature Depth casts collected during 2019 bathymetric surveys

B1. Maps showing modeled wave parameters for wave classes 1, 2,3, and 4 (winter conditions) during low-river-discharge scenarios

B2. Maps showing modeled wave parameters for wave classes 5, 6, 7, and 8 (winter conditions) during low-river-discharge scenarios.

B3. Maps showing modeled wave parameters for wave classes $9,10,11$, and 12 (winter conditions) during low-river-discharge scenarios

B4. Maps showing modeled wave parameters for wave classes $13,14,15$, and 16 (summer conditions) during low-river-discharge scenarios.

B5. Maps showing modeled wave parameters for wave classes 17, 18, and 19 (summer conditions) during low-river-discharge scenarios...

B6. Maps showing modeled wave parameters for wave classes 1, 2, 3, and 4 (winter conditions)during high-river-discharge scenarios

B7. Maps showing modeled wave parameters for wave classes $5,6,7$, and 8 (winter conditions) during high-river-discharge scenarios.

B8. Maps showing modeled wave parameters for wave classes $9,10,11$, and 12 (winter conditions)during high-river-discharge scenarios

B9. Maps showing modeled wave parameters for wave classes $13,14,15$, and 16 (summer conditions)during high-river-discharge scenarios..

B10. Maps showing modeled wave parameters for wave classes 17, 18, and 19 (summer conditions) during high-river-discharge scenarios. 


\section{Tables}

1. Bathymetric and topographic surveys, their starting and ending dates and number of survey days, the number of profiles collected, and the length of survey lines collected during each survey.....

2. Results of analysis of replicate bathymetric profiles, showing replicate number, survey year, subcell, line number, number of boats that surveyed the replicate, overlap distance, and 95 percent confidence intervals.

3. Integrated cumulative net volume changes for each intensively sampled region between 2014 and 2019.

4. Error metrics describing sensitivity of simulated water levels to variations in bed roughness at four observation stations; for each station and model simulation, mean bias, bias-corrected root mean square error, and total root mean square error are provided

5. Specifications of wave classes used in morphological wave-climate schematizations, subdivided into winter and summer conditions 


\section{Conversion Factors}

U.S. customary units to International System of Units

\begin{tabular}{|c|c|c|}
\hline Multiply & By & To obtain \\
\hline \multicolumn{3}{|c|}{ Length } \\
\hline inch (in.) & 2.54 & centimeter $(\mathrm{cm})$ \\
\hline foot $(\mathrm{ft})$ & 0.3048 & meter (m) \\
\hline mile (mi) & 1.609 & kilometer (km) \\
\hline yard (yd) & 0.9144 & meter $(\mathrm{m})$ \\
\hline \multicolumn{3}{|c|}{ Area } \\
\hline acre & 0.4047 & hectare (ha) \\
\hline acre & 0.004047 & square kilometer $\left(\mathrm{km}^{2}\right)$ \\
\hline square foot $\left(\mathrm{ft}^{2}\right)$ & 0.09290 & square meter $\left(\mathrm{m}^{2}\right)$ \\
\hline square mile $\left(\mathrm{mi}^{2}\right)$ & 259.0 & hectare (ha) \\
\hline \multicolumn{3}{|c|}{ Volume } \\
\hline cubic foot $\left(\mathrm{ft}^{3}\right)$ & 0.02832 & cubic meter $\left(\mathrm{m}^{3}\right)$ \\
\hline cubic yard $\left(\mathrm{yd}^{3}\right)$ & 0.7646 & cubic meter $\left(\mathrm{m}^{3}\right)$ \\
\hline \multicolumn{3}{|c|}{ Flow rate } \\
\hline foot per second $(\mathrm{ft} / \mathrm{s})$ & 0.3048 & meter per second $(\mathrm{m} / \mathrm{s})$ \\
\hline cubic foot per second $\left(\mathrm{ft}^{3} / \mathrm{s}\right)$ & 0.02832 & cubic meter per second $\left(\mathrm{m}^{3} / \mathrm{s}\right)$ \\
\hline \multicolumn{3}{|c|}{ Mass } \\
\hline ounce, avoirdupois (oz) & 28.35 & $\operatorname{gram}(\mathrm{g})$ \\
\hline pound, avoirdupois (lb) & 0.4536 & kilogram (kg) \\
\hline \multicolumn{3}{|c|}{ Density } \\
\hline pound per cubic foot $\left(\mathrm{lb} / \mathrm{ft}^{3}\right)$ & 16.02 & kilogram per cubic meter $\left(\mathrm{kg} / \mathrm{m}^{3}\right)$ \\
\hline
\end{tabular}


International System of Units to U.S. customary units

\begin{tabular}{|c|c|c|}
\hline Multiply & By & To obtain \\
\hline \multicolumn{3}{|c|}{ Length } \\
\hline centimeter $(\mathrm{cm})$ & 0.3937 & inch (in.) \\
\hline meter $(\mathrm{m})$ & 3.281 & foot $(\mathrm{ft})$ \\
\hline kilometer (km) & 0.6214 & mile (mi) \\
\hline meter $(\mathrm{m})$ & 1.094 & yard (yd) \\
\hline \multicolumn{3}{|c|}{ Area } \\
\hline hectare (ha) & 2.471 & acre \\
\hline square kilometer $\left(\mathrm{km}^{2}\right)$ & 247.1 & acre \\
\hline square meter $\left(\mathrm{m}^{2}\right)$ & 10.76 & square foot $\left(\mathrm{ft}^{2}\right)$ \\
\hline hectare (ha) & 0.003861 & square mile $\left(\mathrm{mi}^{2}\right)$ \\
\hline \multicolumn{3}{|c|}{ Volume } \\
\hline cubic meter $\left(\mathrm{m}^{3}\right)$ & 35.31 & cubic foot $\left(\mathrm{ft}^{3}\right)$ \\
\hline cubic meter $\left(\mathrm{m}^{3}\right)$ & 1.308 & cubic yard $\left(\mathrm{yd}^{3}\right)$ \\
\hline \multicolumn{3}{|c|}{ Flow rate } \\
\hline meter per second $(\mathrm{m} / \mathrm{s})$ & 3.281 & foot per second $(\mathrm{ft} / \mathrm{s})$ \\
\hline cubic meter per second $\left(\mathrm{m}^{3} / \mathrm{s}\right)$ & 35.31 & cubic foot per second $\left(\mathrm{ft}^{3} / \mathrm{s}\right)$ \\
\hline \multicolumn{3}{|c|}{ Mass } \\
\hline $\operatorname{gram}(\mathrm{g})$ & 0.03527 & ounce, avoirdupois (oz) \\
\hline kilogram (kg) & 2.205 & pound avoirdupois (lb) \\
\hline \multicolumn{3}{|c|}{ Density } \\
\hline kilogram per cubic meter $\left(\mathrm{kg} / \mathrm{m}^{3}\right)$ & 0.06242 & pound per cubic foot $\left(\mathrm{lb} / \mathrm{ft}^{3}\right)$ \\
\hline
\end{tabular}

Temperature in degrees Celsius $\left({ }^{\circ} \mathrm{C}\right)$ may be converted to degrees Fahrenheit $\left({ }^{\circ} \mathrm{F}\right)$ as follows:

$$
{ }^{\circ} \mathrm{F}=\left(1.8 \times{ }^{\circ} \mathrm{C}\right)+32 .
$$

Temperature in degrees Fahrenheit $\left({ }^{\circ} \mathrm{F}\right)$ may be converted to degrees Celsius $\left({ }^{\circ} \mathrm{C}\right)$ as follows:

$$
{ }^{\circ} \mathrm{C}=\left({ }^{\circ} \mathrm{F}-32\right) / 1.8 \text {. }
$$

\section{Datum}

Vertical coordinate information is referenced to the North American Vertical Datum of 1988 (NAVD88).

Horizontal coordinate information is referenced to the North American Datum of 1983 (NAD83).

Altitude, as used in this report, refers to distance above the vertical datum. 


\section{Abbreviations}

\begin{tabular}{ll} 
ADCP & Acoustic Doppler Current Profiler \\
ADV & Acoustic Doppler Velocimeter \\
CDIP & Coastal Data Information Program \\
CI & Confidence interval \\
CRE & Columbia River estuary \\
CRLC & Columbia River littoral cell \\
CTD & Conductivity Temperature Depth \\
ENP & Eastern North Pacific Ocean \\
ENSO & El Niño-Southern Oscillation \\
GNSS & Global navigation satellite system \\
GUI & Graphical User Interface \\
MCR & Mouth of the Columbia River \\
MLLW & Mean lower low water \\
MSL & Mean sea level \\
NAD83 & North American Datum of 1983 \\
NAVD88 & North American Vertical Datum of 1988 \\
NCAR & National Center for Atmospheric Research \\
NCEP & National Centers for Environmental Protection \\
NDBC & National Data Buoy Center \\
NNRP & National Centers for Environmental Protection and National Center for \\
& Atmospheric Research reanalysis project \\
NOAA & National Oceanic and Atmospheric Administration \\
ONR & Office of Naval Research \\
PWC & Personal watercraft \\
RIVET & Rivers and Inlets \\
RMS & Root mean square \\
RTK & Real-time kinematic \\
SJS & South Jetty Site \\
SPIT & Sediment Pathways visualization Tool \\
SWAN & Spectral wave model \\
SWS & Shallow Water Site \\
USACE & U.S. Army Corps of Engineers \\
USGS & U.S. Geological Survey \\
UTM & Universal Transverse Mercator \\
\hline
\end{tabular}




\title{
Observations of Coastal Change and Numerical Modeling of Sediment-Transport Pathways at the Mouth of the Columbia River and its Adjacent Littoral Cell
}

\author{
By Andrew W. Stevens, ${ }^{1}$ Edwin Elias, ${ }^{2}$ Stuart Pearson, ${ }^{2,3}$ George M. Kaminsky, ${ }^{4}$ Peter R. Ruggiero, ${ }^{5}$ \\ Heather M. Weiner, ${ }^{4}$ and Guy R. Gelfenbaum ${ }^{1}$
}

\section{Abstract}

Bathymetric and topographic surveys performed annually along the coastlines of northern Oregon and southwestern Washington documented changes in beach and nearshore morphology between 2014 and 2019. Volume change analysis revealed measurable localized erosion and deposition throughout the study area, but significant net erosion at the regional scale (several kilometers $[\mathrm{km}]$ ) was limited to Benson Beach, Wash., a 3-km-long stretch of coastline immediately north of the Columbia River inlet. Despite the placement of approximately 6.3 million cubic meters $\left(\mathrm{Mm}^{3}\right)$ of sand dredged from the Columbia River navigational channel at nearshore placement sites located nearby, Benson Beach eroded $2.1 \pm 0.8 \mathrm{Mm}^{3}$ over the 5-year (yr) monitoring time period $\left(420,000\right.$ cubic meters/year $\left.\left[\mathrm{m}^{3} / \mathrm{yr}\right]\right)$. A hydrodynamic and sediment transport model was applied to simulate sedimenttransport fluxes, and a new visualization technique was developed to evaluate the linkages between nearshore dredge placement sites and adjacent coastlines near the mouth of the Columbia River. The model results indicate the dominance of wave processes on sediment-transport patterns outside of the inlet and suggest that the current configuration of the nearshore dredge placement sites can be improved to more efficiently enhance the sediment budget of Benson Beach to reduce erosion and mitigate associated coastal change hazards.

\section{Introduction}

Tidal inlets are an important resource, providing habitat for estuarine species and a physical link between land and sea. The Columbia River is the largest river on the west coast of the United States, and its tidal inlet includes a federally managed navigation channel that connects the deep-water ports of Vancouver, Wash., and Portland, Ore., to the Pacific

\footnotetext{
${ }^{1}$ U.S. Geological Survey.

${ }^{2}$ Deltares.

${ }^{3}$ Delft University of Technology.

${ }^{4}$ Washington State Department of Ecology.

${ }^{5}$ Oregon State University.
}

Ocean. Sediment historically supplied from the Columbia River nourishes beaches and protects infrastructure along $165 \mathrm{~km}$ of coastline, while sedimentation in the navigation channel has necessitated costly maintenance dredging. Effective regional sediment-management decisions, which need to balance the requirements of safe navigation, habitat preservation, and beach stability in the Columbia River littoral cell (CRLC), require understanding and prediction of the spatial and temporal distribution of sediment fluxes, erosion, and accumulation.

Although most of the beaches along the CRLC have been prograding (Ruggiero and others, 2016), severe localized erosion has prompted a variety of mitigation strategies, including nearshore placement of dredged material and beach nourishment (for example, Stevens and others, 2012). Strategic placement of sand dredged from the mouth of the Columbia River (MCR) navigational channel could help reduce local sand deficits and shoreline retreat, but a detailed understanding of coastal sediment budgets and transport processes that is sufficient to select both the volumes of sediment needed and appropriate placement locations is lacking. This study utilizes a combination of field measurements and numerical model experiments to improve our understanding of sediment transport pathways and coastal sediment budgets in the vicinity of the MCR.

This report describes two primary research tasks. In Task 1, recent changes in coastal sand volume and beach morphology are quantified within the CRLC on the basis of bathymetric and topographic surveys performed annually between 2014 and 2019. Task 2 describes the application of a hydrodynamic and sediment transport model of the Columbia River estuary (CRE) to help understand the processes responsible for sediment dispersal and also identify transport pathways between the Columbia River and adjacent shorelines. The combination of field measurements and numerical modeling aims to inform regional sediment management decisions and the adoption of a sustainable maintenance strategy. After describing the environmental setting, we describe the methodology and discuss the results of each task separately. Concluding remarks are provided that discuss and synthesize the results from the field surveys (Task 1) and numerical modeling (Task 2). 


\section{Environmental Setting}

The Columbia River drains an area of approximately 670,000 square kilometers $\left(\mathrm{km}^{2}\right)$. Discharge at the river mouth, which varies between about 3,000 and 17,000 cubic meters per second $\left(\mathrm{m}^{3} / \mathrm{s}\right)$, is characterized by low flow during the late summer and fall and high flow during the spring (Sherwood and Creager, 1990). The Columbia River historically has been the primary source of sediment to approximately 165 kilometers $(\mathrm{km})$ of shoreline between Point Grenville, Wash., and Tillamook Head, Ore. (fig. 1). The CRLC consists of four barrier beach plains, or subcells, separated by the entrances of Grays Harbor and Willapa Bay, Wash., and the Columbia River. The gently sloping, sandy barrier beaches and wide surf zones that characterize the CRLC developed and began to prograde approximately 6,000 years (yr) ago when the rate of relative sea level rise began to decrease (Peterson and others, 2010). Prehistoric progradation of the barrier beaches was interrupted episodically by large earthquakes that produced tsunamis and coseismic subduction (Atwater, 1996).

The Columbia River discharges into the Eastern North Pacific Ocean (ENP) at the border of Oregon and Washington. The ENP is characterized by an extreme wave climate where winter storms regularly generate significant wave heights of more than 10 meters (m), and strong seasonal variations result in mean average wave heights of approximately 3.8 and $1.6 \mathrm{~m}$ for winter and summer, respectively (Ruggiero and others, 2010). Within the inlet, the flow and sediment transport fields are modified by a large tidal range, as well as ocean and wind waves and estuarine circulation associated with major freshwater inputs (Elias and Gelfenbaum, 2009). Ocean tides are classified as mixed semidiurnal with a mean tidal range of $2.1 \mathrm{~m}$ (National Oceanic and Atmospheric Administration [NOAA] station 9439040). Towards (and inside of) the MCR

\section{$124.0^{\circ} \mathrm{W}$}

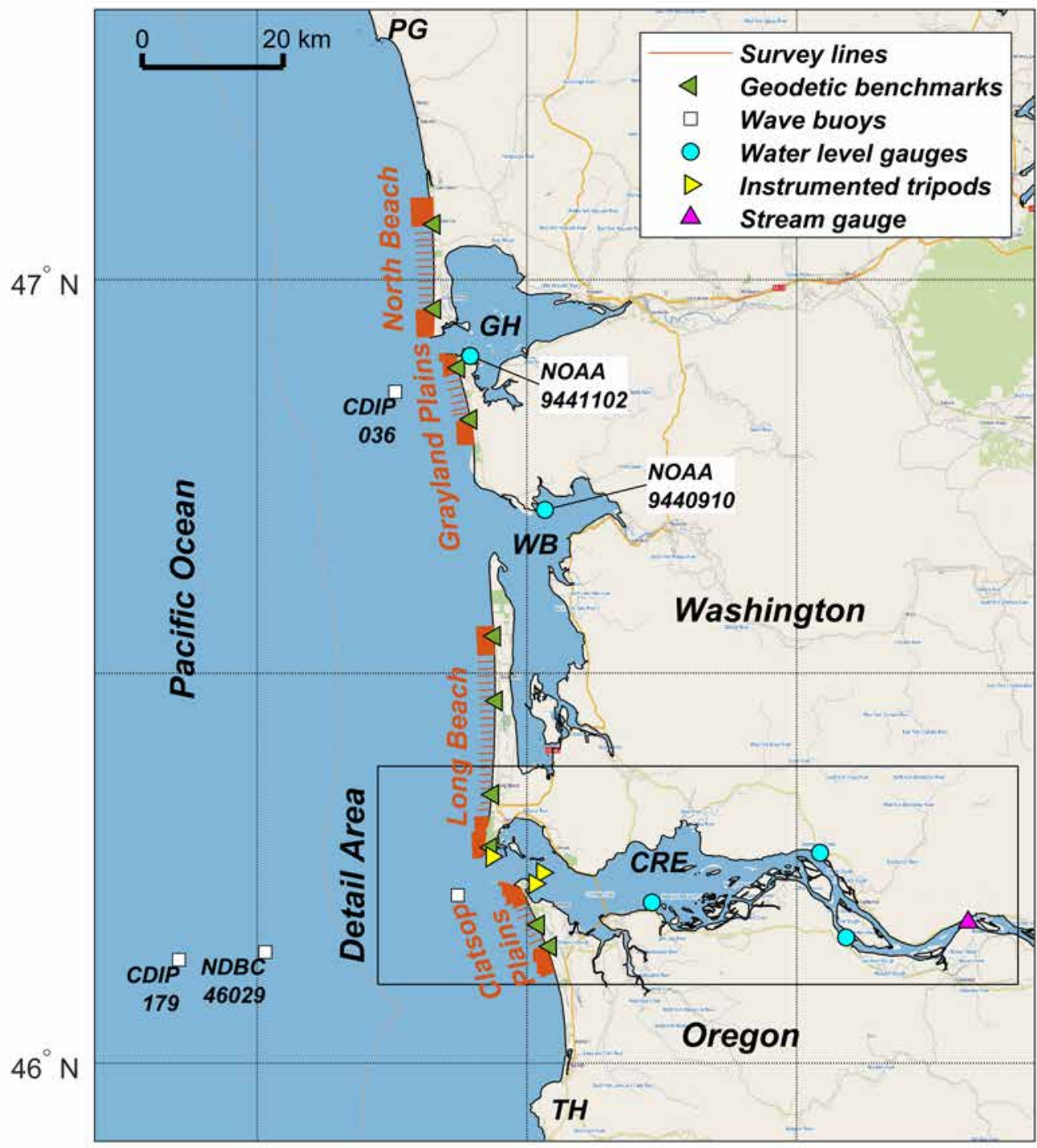

Figure 1. Map of Columbia River littoral cell, showing locations of its subcells (from north to south, North Beach, Grayland Plains, Long Beach, and Clatsop Plains), major estuary entrances (CRE, Columbia River estuary; GH, Grays Harbor; WB, Willapa Bay), and natural headlands (PG, Point Grenville; TH, Tillamook Head) that represent its northern and southern extents, respectively, also shown are locations of survey lines, geodetic benchmarks, wave buoys, water level gauges, instrumented tripods, and stream gauges. Black box shows area of figure 2. Other abbreviations: CDIP, Coastal Data Information Program; km, kilometer(s); NDBC, National Data Buoy Center; NOAA, National Oceanic and Atmospheric Administration. 
and CRE, the ocean tides are modified by bed friction on the relatively shallow tidal delta and shoals, as well as by interaction with fluvial discharges, wind, and wave stresses.

The MCR is characterized by an approximately 13-m-deep navigational channel in which the depth and location are maintained with regular dredging, training dikes, and three major stone jetties (fig. 2). The North and South Jetties extend seaward about 3.5 and $10 \mathrm{~km}$, respectively, and Jetty A extends southward about $1.5 \mathrm{~km}$. The severe wave climate that impacts the MCR has eroded the jetty tips about 250 to $500 \mathrm{~m}$ in recent years. Located slightly inside of the inlet and orthogonal to the channel axis, Jetty
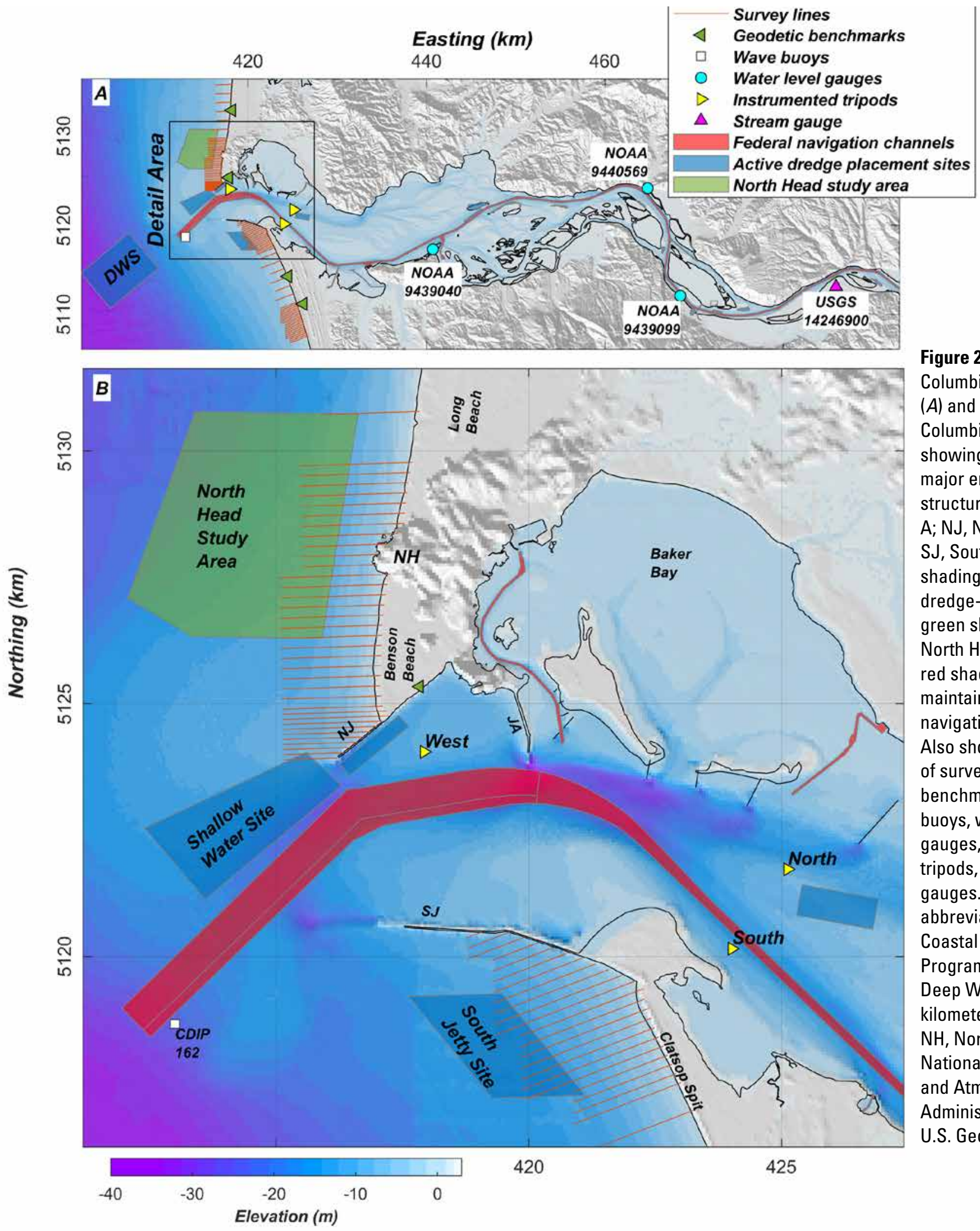

Figure 2. Maps of Columbia River estuary $(A)$ and mouth of Columbia River $(B)$, showing locations of major engineering structures (JA, Jetty A; NJ, North Jetty; SJ, South Jetty). Blue shading shows active dredge-placement sites; green shading shows North Head study area; red shading shows maintained federal navigation channels. Also shown are locations of survey lines, geodetic benchmarks, wave buoys, water level gauges, instrumented tripods, and stream gauges. Other abbreviations: CDIP, Coastal Data Information Program; DWS, Deep Water Site; km, kilometer(s); m, meter(s); $\mathrm{NH}$, North Head; NOAA, National Oceanic and Atmospheric Administration; USGS, U.S. Geological Survey. 
A was constructed during the 1930s to further stabilize the shifting channel. The construction of the jetties, however, has altered hydrodynamic processes, transport pathways, and sediment supplies, resulting in increased progradation rates for several decades along much of the CRLC (Kaminsky and others, 2010). Although progradation along much of the CRLC continues to the present (2020) (Ruggiero and others, 2016), severe beach erosion has been observed at several locations, including Benson Beach, a 3-km stretch of coastline immediately adjacent to the north of the MCR (fig. 2).

Between 2 and $4 \mathrm{Mm}^{3}$ of sand-sized sediment is dredged annually to maintain the entrance to the federal navigation channel in the MCR (U.S. Army Corps of Engineers [USACE], 2019). The dredged material is placed at one of several designated areas located throughout the region (fig. 2), with roughly 30 percent of the dredged sediment placed at the Deep Water Site and removed from the active littoral system. Most of the sediment that is dredged from the entrance channel is placed in either the Shallow Water or South Jetty Sites, located in the nearshore in water depths between approximately 12 and $22 \mathrm{~m}$. The goal of placement in these shallow locations is to increase the coastal sediment supply and reduce erosion along shorelines adjacent to the MCR. The capacity of the nearshore sites is limited to control mounding, minimize impacts to marine resources, and reduce interference with other marine activities (for example, fishing). Owing to the current constraints to place dredged material within existing nearshore sites, a new nearshore dredge-placement area offshore of North Head is being studied, and small quantities of sediment were placed within the North Head study area in 2018 and 2019.

\section{Task 1 - Observations of Coastal Change}

In this section, we describe observations of coastal change derived from repeated annual field surveys of nearshore bathymetry and beach topography between 2014 and 2019 (table 1). These data are intended to inform regional sediment management by quantifying the magnitude and rates of change in sand volume and documenting the effectiveness of implemented management strategies aimed at reducing deficits in local sediment budgets. Although the focus of the hydrodynamic and sediment transport modeling described in Task 2 is focused on the MCR and its proximal shorelines, here we present bathymetric and topographic data collected over a larger area that encompasses a significant part of the CRLC. The broader spatial coverage provides context for the observations of coastal change around the MCR. Of particular interest is the comparison of the patterns of erosion and deposition around the MCR to the observations around the mouth of Grays Harbor, the nearby inlet to the north that also is stabilized with jetties and is maintained with regular dredging.

Bathymetric and topographic data were collected along a series of shore-perpendicular transects spaced at 100- to 1,000-m intervals between Tillamook Head and Point Grenville (fig. 1) in the CRLC. The survey-sampling scheme described in Ruggiero and others (2005) was designed to provide broad spatial coverage throughout a large part of the CRLC and intensive sampling along selected regions to resolve variability of smaller features. The profiles extend from 12- to $15-\mathrm{m}$ water depth to just landward of the primary dune crest. The surveys were conducted annually during spring tides in the summer months of July, August, and September to quantify beach and nearshore morphology at a consistent time of year to minimize aliasing in our analysis that is due to strong seasonal patterns in wave energy, water levels, and fluvial discharge (fig. 3). In order to maximize coverage of intertidal areas, nearshore bathymetric data were acquired during high tide, and topographic measurements were collected during low tide, often resulting in overlap between topographic and bathymetric profiles. Each survey required between 7 and 10 working days to complete, depending on environmental conditions and equipment issues. The locations of bathymetric and topographic survey lines and environmental conditions during the surveys are provided in appendix A (bathymetric and topographic data and associated metadata are provided in Stevens and others, 2019).

Table 1. Bathymetric and topographic surveys, their starting and ending dates and number of survey days, the number of profiles collected, and the length of survey lines collected during each survey.

[Abbreviations: km, kilometer(s); no., number]

\begin{tabular}{|c|c|c|c|c|c|c|c|}
\hline \multirow[b]{2}{*}{ Year } & \multirow[b]{2}{*}{ Start date } & \multirow[b]{2}{*}{ End date } & \multirow[b]{2}{*}{$\begin{array}{l}\text { No. of survey } \\
\text { days }\end{array}$} & \multicolumn{2}{|c|}{ No. of profiles } & \multicolumn{2}{|c|}{ Length (km) } \\
\hline & & & & $\begin{array}{c}\text { Bathymetric } \\
\text { survey }\end{array}$ & $\begin{array}{c}\text { Topographic } \\
\text { survey }\end{array}$ & $\begin{array}{c}\text { Bathymetric } \\
\text { survey }\end{array}$ & $\begin{array}{c}\text { Topographic } \\
\text { survey }\end{array}$ \\
\hline 2015 & July 13,2015 & August 11, 2015 & 7 & 219 & 200 & 425 & 321 \\
\hline 2016 & August 15, 2016 & September 2, 2016 & 10 & 222 & 202 & 422 & 646 \\
\hline 2019 & July 29, 2019 & August 13, 2019 & 7 & 220 & 201 & 430 & 440 \\
\hline
\end{tabular}



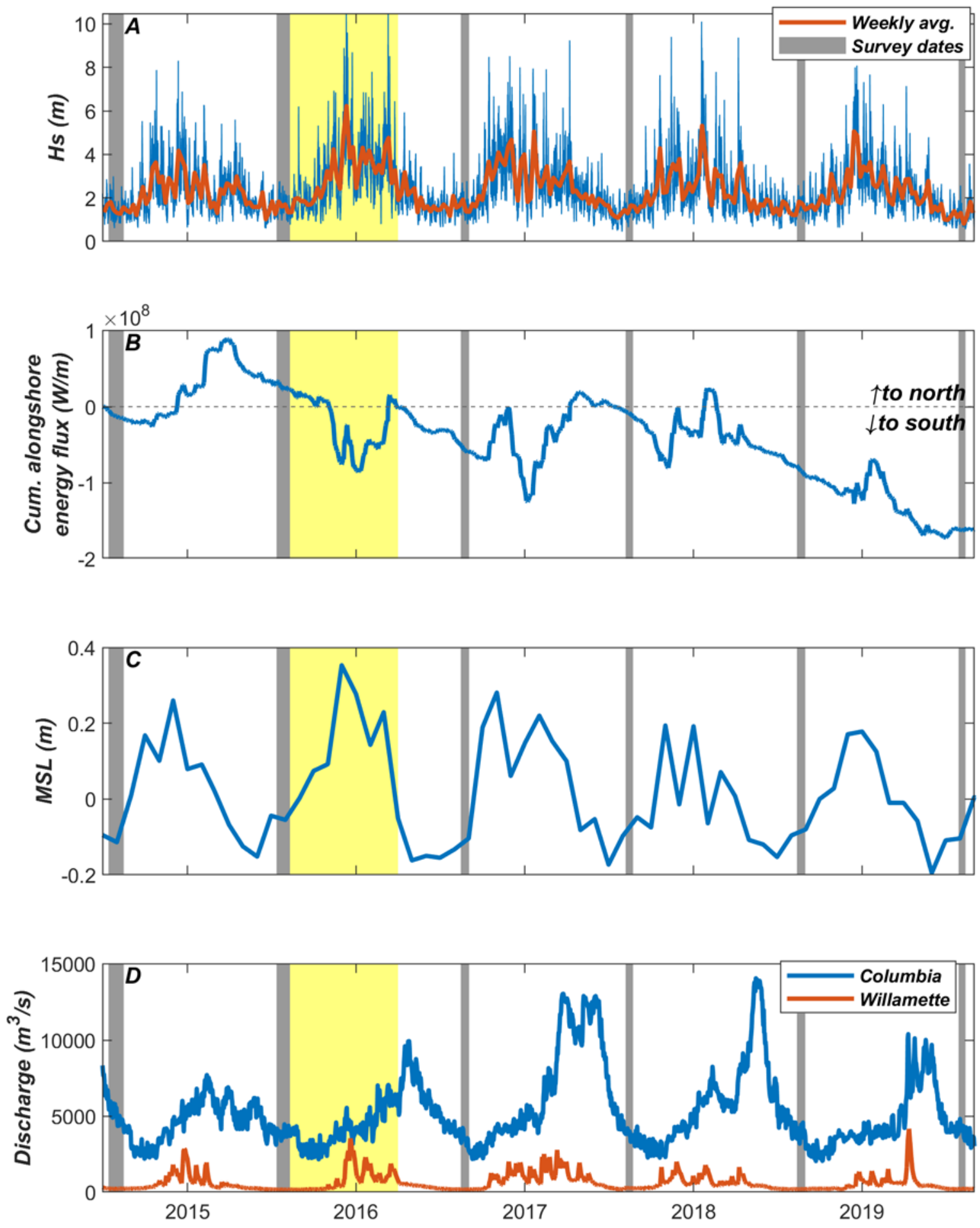

Figure 3. Time-series plots of $(A)$ wave heights $(\mathrm{Hs}),(B)$ cumulative along-shore wave-energy flux, (C) monthly mean sea level (MSL) observed at Westport, Wash. (National Oceanic and Atmospheric Administration [NOAA] station 9441102), and (D) river discharge of Columbia River measured at Bonneville Dam (U.S. Army Corps of Engineers [USACE]) and Willamette River at Salem, Ore. (U.S. Geological Survey [USGS] station 14191000). Gray vertical lines separate survey years; yellow shading shows time of very strong 2015-16 El Niño-Southern Oscillation. Wave heights $(A)$ and cumulative energy-flux $(B)$ data were derived primarily from Coastal Data Information Program (CDIP) buoy 179; gaps in buoy record were filled with data from National Data Buoy Center (NDBC) buoy 46029. Other abbreviations: km, kilometer(s); m, meter(s); s, second; W, watt. 


\section{Methods}

\section{Field Acquisition}

\section{Bathymetric Data}

Bathymetric data were collected using personal watercraft (PWC) equipped with single-beam sonar systems and global navigation satellite system (GNSS) receivers (fig. 4A). The sonar systems consisted of an Odom Echotrac CV-100 singlebeam echosounder and a $200-\mathrm{kHz}$ transducer with a $9^{\circ}$ beam angle. Raw acoustic backscatter returns were digitized by the echosounder, using a vertical resolution of $1.25 \mathrm{~cm}$. Depths from the echosounders were computed using sound-velocity profiles measured using a YSI CastAway Conductivity
Temperature Depth (CTD) during the survey. Positioning of the survey vessels was determined at 5 to $10 \mathrm{~Hz}$, using Trimble R7 GNSS receivers operating primarily in real-time kinematic (RTK) mode. Output from the GNSS receivers and sonar systems were combined in real time on the PWC by a computer running HYPACK hydrographic-survey software. Navigation information was displayed on a video monitor, allowing PWC operators to navigate along survey lines at speeds of 2 to 3 $\mathrm{m} / \mathrm{s}$. The profiles were surveyed from the offshore extent of the survey line through the surf zone to a depth as shallow as possible near the shoreline, depending on wave conditions.

Bathymetric data were postprocessed using a custom Graphical User Interface (GUI) programmed with the computer program MATLAB. Spurious depths were removed, and the GUI was used to hand digitize the bottom in areas

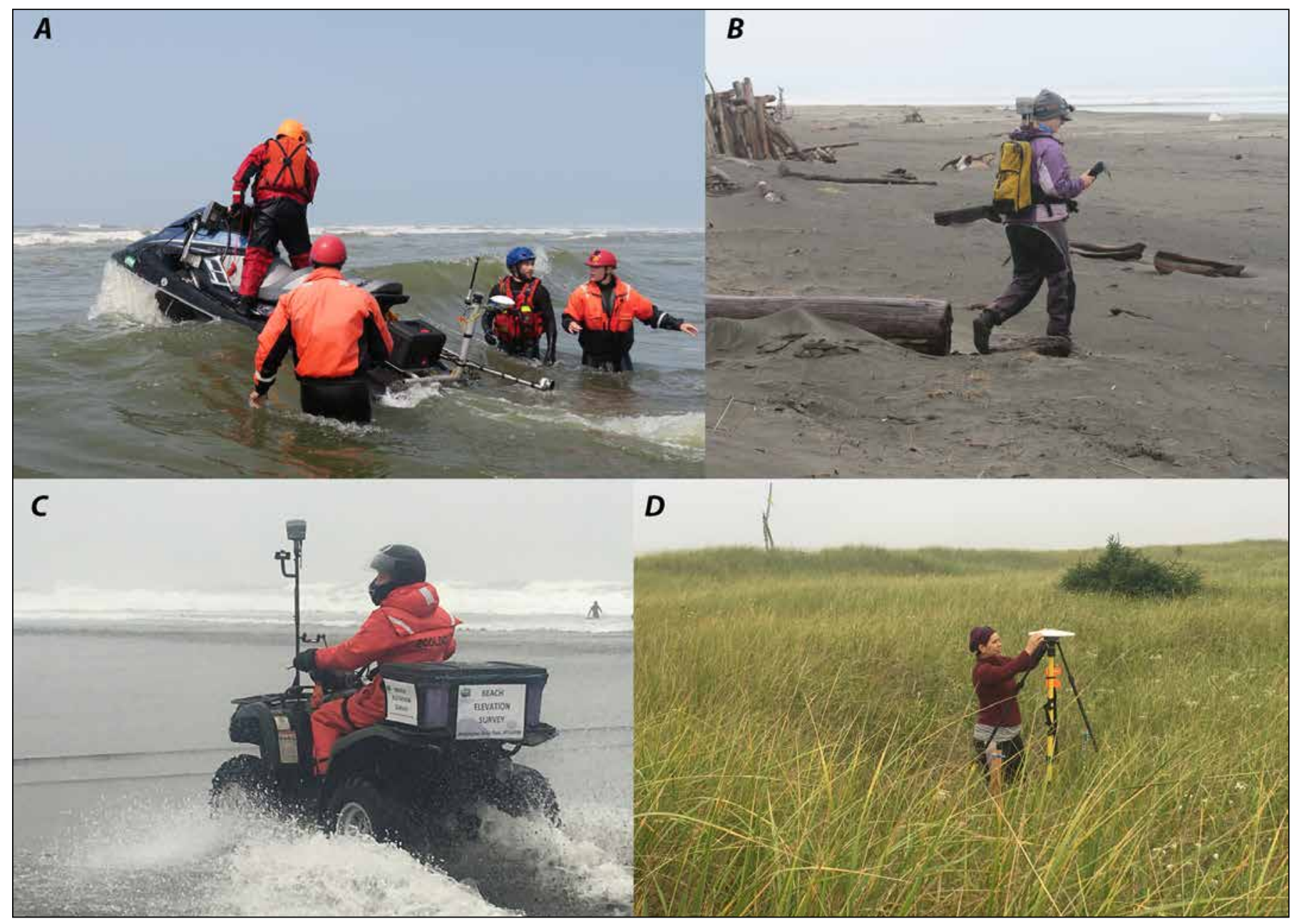

Figure 4. Field equipment used to collect bathymetric and topographic data, including $(A)$ personal watercraft equipped with singlebeam sonar and global navigation satellite system (GNSS) receiver, $(B)$ GNSS receiver, mounted on backpack, being used by surveyor collecting topographic profile, $(C)$ all-terrain vehicle equipped with GNSS receiver, and $(D)$ GNSS antenna being set up by surveyor to use for geodetic control during surveys. Photographs in $A$ and $B$ by Andrew Stevens; in $C$ and $D$, by Heather Weiner. 
where the echosounder signal processing failed. This was common in the surf zone where turbulence and bubbles in the water column added noise to the acoustical signal. After the raw depths were adjusted, a running mean with a window length of 5 to 20 points (1-6 m long) was applied to smooth the bathymetric profiles.

\section{Topographic Data}

Topographic profiles were collected by walking along survey lines, using GNSS receivers mounted on backpacks (fig. 4B). Prior to data collection, vertical distances between the GNSS antennas and the ground were measured using a tape measure. Each backpack system consisted of a Trimble R7, R8, R9, or R10 GNSS receiver. Zephyr Model 2 GNSS antennas were used for GNSS systems without integrated antennas. Hand-held data collectors were used to log raw data and display navigational information, allowing surveyors to navigate along survey lines. Profiles were surveyed from the landward edge of the study area (either the base of a bluff, an engineering structure, or just landward of the primary dune) over the beach foreshore, to wading depth on the same series of transects as nearshore bathymetric surveys that were conducted during the same time period. Additional topographic data were collected between survey lines in some areas with an all-terrain vehicle (ATV) equipped with a Trimble R8 or R10 GNSS receiver (fig. $4 \mathrm{C}$ ) to constrain the elevations and along-shore extents of major morphological features.

\section{Geodetic Control}

Geodetic control for the bathymetric and topographic surveys was established using the Washington Coastal Geodetic Network, a set of physical benchmarks that have published coordinates relative to NAD83. The elevations of all the benchmarks in the geodetic network achieve a vertical accuracy of $2 \mathrm{~cm}$ or better (Daniels and others, 1999). A GNSS base station, consisting of a Trimble R7 GNSS receiver and Zephyr Geodetic Model 2 antenna, placed on one of the benchmarks provided geodetic control for the bathymetric and topographic survey platforms (fig. 4D). A Pacific Crest ADL Vantage Pro radio modem was used to transmit differential corrections from the base station to the survey platforms in real time, at $1-\mathrm{Hz}$ intervals. The positioning data from the bathymetric platforms were later postprocessed using Waypoint Grafnav; these data superseded the original positions recorded in real time. The positions of the topographic platforms collected in RTK mode were retained, and Trimble Business Center software was used to apply differential corrections to topographic data collected in autonomous mode when VHF communication with the base station failed. Orthometric elevations relative to the NAVD88 vertical datum were computed for all survey platforms, using National Geodetic Survey Geoid12b offsets.

\section{Vertical Precision}

Precisely quantifying the vertical precision and accuracy of bathymetry data is notoriously difficult, as rarely do fixed objects on the seabed have known elevations. Although previous studies often relied on manufacturer-supplied estimates of instrument precisions (for example, Ruggiero and others, 2005), the relatively large number of survey vessels operating during this study presents an opportunity to develop a statistically robust operational estimate of the vertical precision of the single-beam bathymetry technique. Here we describe analysis of replicate profiles that were surveyed by each PWC to establish the vertical precision of the bathymetric measurements, and we use the estimated precision to quantify uncertainty in volumetric change computed between surveys.

A replicate profile was typically surveyed by each PWC on each day of survey operations. To quantify the vertical precision of bathymetric data, the horizontal positions of the PWCs were rotated in the cross-profile coordinate system, and elevations were binned at 1-m intervals (fig. $5 A$ ) along the profile. Elevations that had positions more than $5 \mathrm{~m}$ from the target profile were omitted from further analysis. For the retained elevations, the 95 percent confidence interval was computed for each 1-m segment containing measurements from three or more survey vessels (fig. $5 B$ ). The 95 th percentile of the 95 percent confidence intervals (fig. 5C) was selected to represent the precision of the replicate profile. The 95th percentile was favored over other statistics to reflect the conservative nature of this analysis.

During the six surveys performed between 2014 and 2019 , a total of 30 replicate profiles, surveyed by at least three separate vessels, were collected and analyzed (table 2). The average vertical precision for the replicate profiles varied between 4 and $13 \mathrm{~cm}$, with a mean of $8 \mathrm{~cm}$. Variations in the average vertical precision between years were small, compared to the variability between profiles. No clear dependence of the vertical precision on depth was observed in the replicate profiles. We, therefore, selected the single value of $8 \mathrm{~cm}$ to reflect the average vertical uncertainty for all bathymetric data collected during this study; this value is consistent with vertical uncertainties, which were estimated using the same survey equipment, of 7 and $6.7 \mathrm{~cm}$ reported by Gelfenbaum and others (2015a) and Snyder and others (2016), respectively.

\section{Volume Change and Uncertainty Analysis}

Changes in sediment volume were calculated for each profile surveyed along the CRLC in the following manner. Bathymetric and topographic data collected along each profile were rotated into the cross-profile coordinate system defined by the end points of the planned profile. Survey points that had positions more than $20 \mathrm{~m}$ from the target profile were removed, and the elevations of the remaining points were 

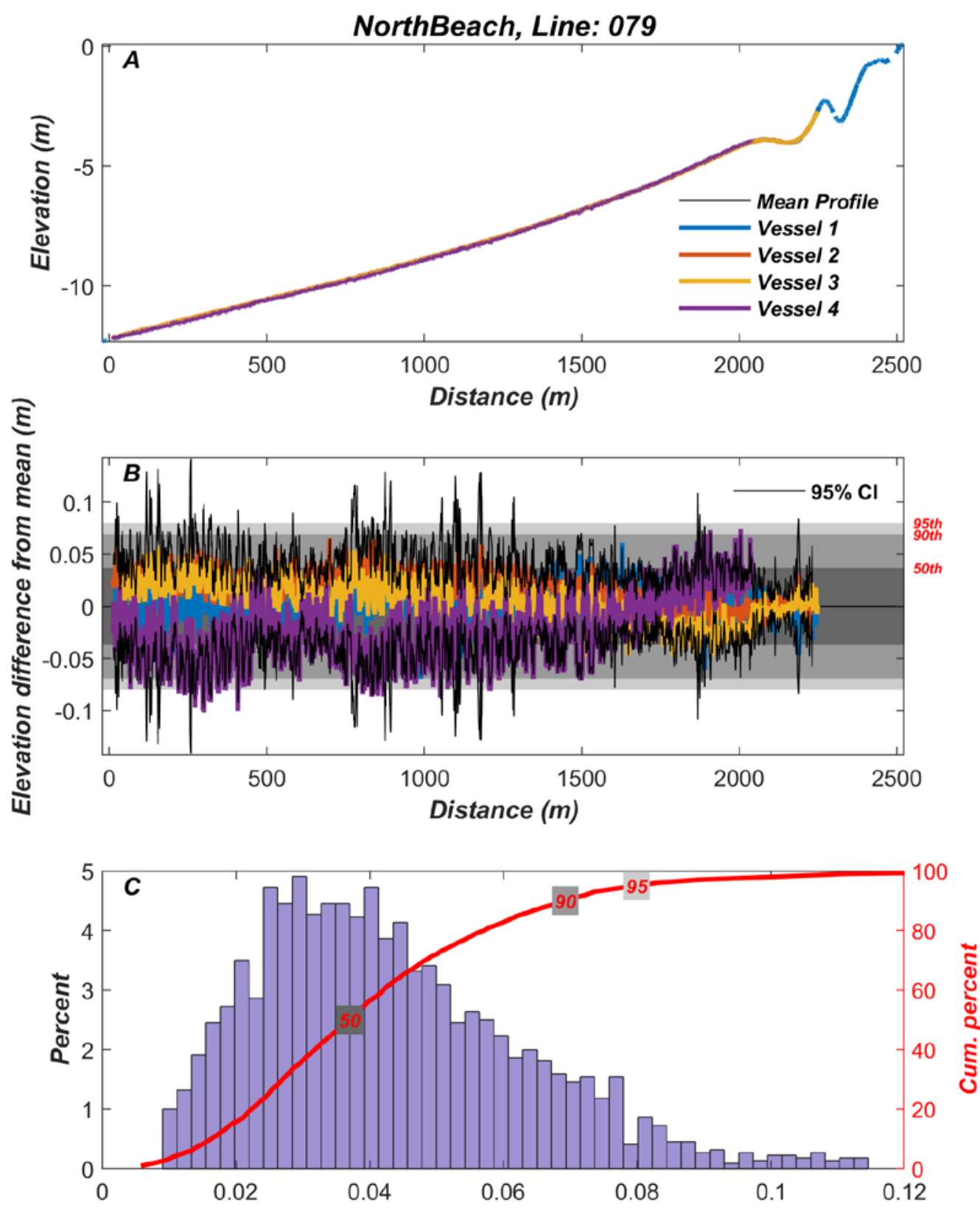

Figure 5. Example analysis of replicate profile to estimate vertical uncertainty in bathymetric measurements. $A$, Elevation profile from separate vessels that surveyed replicate. $B$, Deviations from mean and 95 percent confidence intervals (CI) for each 1-m segment along profile. $C$, Histogram (purple bars) and cumulative distribution (red line) of 95 percent confidence intervals along profile. Results from analysis of all replicates are provided in table 2. Other abbreviation: $\mathrm{m}$, meter(s). 
Table 2. Results of analysis of replicate bathymetric profiles, showing replicate number, survey year, subcell, line number, number of boats that surveyed the replicate, overlap distance, and 95 percent confidence intervals (summarized as the 50th percentile, 90th percentile, and 95th percentile values).

[Subcells: CP, Clatsop Plains; GP, Grayland Plains; LB, Long Beach; NB, North Beach. Other abbreviations: m, meter(s); N, replicate; no., number]

\begin{tabular}{|c|c|c|c|c|c|c|c|c|}
\hline \multirow[b]{2}{*}{ Replicate } & \multirow[b]{2}{*}{ Year } & \multirow[b]{2}{*}{ Subcell } & \multirow[b]{2}{*}{ Line no. } & \multirow[b]{2}{*}{$\mathbf{N}$} & \multirow{2}{*}{$\begin{array}{c}\text { Overlap } \\
\text { distance }(\mathrm{m})\end{array}$} & \multicolumn{3}{|c|}{$95 \%$ confidence intervals $(\mathrm{m})$} \\
\hline & & & & & & $\begin{array}{c}\text { 50th } \\
\text { percentile }\end{array}$ & $\begin{array}{c}\text { 90th } \\
\text { percentile }\end{array}$ & $\begin{array}{c}\text { 95th } \\
\text { percentile }\end{array}$ \\
\hline 1 & 2014 & GP & 42 & 4 & 1,588 & 0.04 & 0.06 & 0.07 \\
\hline 2 & 2014 & LB & 60 & 3 & 666 & 0.04 & 0.07 & 0.08 \\
\hline 3 & 2014 & LB & 190 & 3 & 881 & 0.05 & 0.12 & 0.14 \\
\hline 4 & 2014 & NB & 25 & 4 & 1,402 & 0.04 & 0.07 & 0.08 \\
\hline 5 & 2014 & NB & 74 & 4 & 1,841 & 0.03 & 0.05 & 0.06 \\
\hline 6 & 2015 & $\mathrm{CP}$ & 101 & 4 & 1,654 & 0.03 & 0.06 & 0.07 \\
\hline 7 & 2015 & GP & 34 & 3 & 343 & 0.04 & 0.08 & 0.09 \\
\hline 8 & 2015 & LB & 60 & 4 & 1,794 & 0.03 & 0.05 & 0.06 \\
\hline 9 & 2015 & LB & 175 & 4 & 514 & 0.03 & 0.07 & 0.08 \\
\hline 10 & 2015 & NB & 25 & 4 & 1,573 & 0.03 & 0.06 & 0.07 \\
\hline 11 & 2015 & NB & 79 & 4 & 2,259 & 0.04 & 0.07 & 0.09 \\
\hline 12 & 2016 & $\mathrm{CP}$ & 88 & 4 & 1,691 & 0.05 & 0.09 & 0.11 \\
\hline 13 & 2016 & $\mathrm{CP}$ & 101 & 3 & 1,697 & 0.05 & 0.08 & 0.09 \\
\hline 14 & 2016 & GP & 44 & 4 & 1,472 & 0.02 & 0.04 & 0.05 \\
\hline 15 & 2016 & LB & 160 & 3 & 691 & 0.04 & 0.08 & 0.10 \\
\hline 16 & 2016 & NB & 25 & 5 & 1,060 & 0.02 & 0.04 & 0.04 \\
\hline 17 & 2016 & NB & 79 & 4 & 1,700 & 0.04 & 0.07 & 0.08 \\
\hline 18 & 2017 & $\mathrm{CP}$ & 101 & 4 & 1,500 & 0.03 & 0.05 & 0.06 \\
\hline 19 & 2017 & GP & 48 & 4 & 1,406 & 0.03 & 0.04 & 0.05 \\
\hline 20 & 2017 & LB & 150 & 5 & 1,784 & 0.03 & 0.06 & 0.07 \\
\hline 21 & 2017 & LB & 216 & 4 & 1,442 & 0.03 & 0.05 & 0.06 \\
\hline 22 & 2017 & NB & 25 & 4 & 1,258 & 0.02 & 0.03 & 0.04 \\
\hline 23 & 2017 & NB & 99 & 4 & 1,845 & 0.03 & 0.04 & 0.05 \\
\hline 24 & 2018 & $\mathrm{CP}$ & 48 & 4 & 1,834 & 0.04 & 0.09 & 0.11 \\
\hline 25 & 2018 & GP & 48 & 3 & 815 & 0.03 & 0.05 & 0.06 \\
\hline 26 & 2018 & GP & 48 & 3 & 555 & 0.04 & 0.06 & 0.07 \\
\hline 27 & 2018 & LB & 60 & 4 & 1,340 & 0.03 & 0.06 & 0.08 \\
\hline 28 & 2018 & LB & 145 & 4 & 1,232 & 0.05 & 0.10 & 0.12 \\
\hline 29 & 2018 & NB & 25 & 3 & 1,117 & 0.04 & 0.07 & 0.08 \\
\hline \multirow[t]{4}{*}{30} & 2018 & NB & 79 & 4 & 2,201 & 0.04 & 0.07 & 0.08 \\
\hline & & & & & Average & 0.03 & 0.06 & 0.08 \\
\hline & & & & & Minimum & 0.02 & 0.03 & 0.04 \\
\hline & & & & & Maximum & 0.05 & 0.12 & 0.14 \\
\hline
\end{tabular}


binned at 1-m intervals. Small gaps along relatively smooth sections in the profiles were filled with linear interpolation. Changes in sediment volume between surveys were computed by summing the differences in elevation along each 1-m-long segment along the profile. No change-detection threshold was applied to remove volume changes that were less than the estimated uncertainty, as the application of detection thresholds can lead to erroneous interpretations of volume change (Anderson, 2019).

Volume changes were calculated separately for depth zones both above and below $0 \mathrm{~m}$ NAVD88, hereafter referred to as "beach" and "nearshore" areas, respectively. As defined here, the beach region roughly includes intertidal and subaerial elevations because the $0-\mathrm{m}$ NAVD88 contour is $0.25 \mathrm{~m}$ above mean lower low water (MLLW) level at Toke Point, Wash., tide gauge (NOAA station 9440910) and $0.07 \mathrm{~m}$ below MLLW for the Astoria, Ore., tide gauge (NOAA station 9439040). Volume changes along each intensively sampled region where survey lines were spaced no more than $200 \mathrm{~m}$ apart were computed by multiplying the profile-averaged volume changes by the distance between the profiles and summing these volumes for all the profiles acquired within the region.

Uncertainty in volume change was assessed on the basis of the vertical precision of the bathymetry measurements, derived from analysis of repeat lines. Here, we assume that vertical precision is equivalent to vertical accuracy between surveys. Previously published studies (for example, Gelfenbaum and others, 2015a) have used this assumption to generate uncertainty estimates for volume-change calculations using similar survey methodology. The total vertical uncertainty was calculated by assuming the error between surveys are independent and by summing the average precision of each bathymetric survey $(8 \mathrm{~cm})$ in quadrature (for example Taylor, 1997) to yield a total uncertainty between surveys of $\pm 11 \mathrm{~cm}$. The profile-averaged uncertainty in volume change is computed by multiplying the vertical uncertainty by the total distance of the survey profile. This is a very conservative approach because all of the uncertainty is treated as systematic error (bias). Future work will focus on separately quantifying the systematic and spatially correlated random components of error (as explained in Anderson, 2019) to reduce the uncertainty in the volume-change estimates. Although topographic-elevation measurements using our methodology have less vertical uncertainty than the bathymetric data owing to the relatively simple survey system and geometry, we do not distinguish between the bathymetric and topographic parts of the profile, and we use the estimated precision of the bathymetric data to characterize vertical uncertainty for the entire profile.

\section{Results}

A total of 2,560 km of nearshore bathymetric-survey lines and 2,837 km of topographic-survey lines were collected during the six surveys performed between 2014 and 2019 (table 1). Results of the volume-change analysis, which revealed measurable net erosion and deposition in each of the subcells surveyed, are presented as follows. First, we describe the large-scale along-shore patterns of net erosion and accretion that were computed for each profile collected along the CRLC. Next, we analyze the net elevation change and examine the variability in sediment-volume change across the beach and nearshore depth zones for each subcell. We provide example profiles within each region and subcell to examine the morphological changes associated with observed net erosion and accumulation. Finally, we integrate the volume changes for each region that was surveyed more intensively (with profiles spaced at 100-200-m intervals) to identify large-scale, regional, net volume changes and temporal dynamics along the CRLC.

The largest net changes in sand volume integrated over all of the profiles were observed in proximity to the two maintained inlets of Grays Harbor and the Columbia River (fig. 6). At both locations, net erosion was observed north of the inlet, and net accumulation was observed to the south. Net volume change outside of these two locations, which was generally small, was characterized by deposition along the Long Beach and Clatsop Plains subcells and erosion along the southern Grayland Plains subcell. These patterns are described in detail for each subcell below.

\section{North Beach Subcell}

Cumulative net changes in elevation and volume between 2014 and 2019 were spatially variable throughout the North Beach subcell (fig. 7). The beaches (that is, parts of the profile above $0 \mathrm{~m}$ ) along Ocean City, Wash. (northern North Beach subcell), and central North Beach accumulated sediment, whereas no consistent accretional trends at the south end of the North Beach subcell were observed. Measurable erosion in the nearshore area was observed along parts of Ocean Shores between 2016 and 2017, but the trend was reversed in subsequent years, and net changes in nearshore sediment volume were negligible.

Geomorphic and volumetric changes in the Ocean City region were relatively uniform along the coast, as shown in figures 7 and 8. A combined topographic and bathymetric profile is representative of the temporal beach and nearshore dynamics throughout the about $3.5 \mathrm{~km}$ stretch of coast (fig. 8). Volume changes in the nearshore area of Ocean City were largely driven by changes in nearshore sandbar size and position. A broad zone of sediment that accumulated between 2014 and 2019 (fig. 8A) may represent the movement and decay of a sandbar that migrated from the inner surf zone offshore during this time period (for example, Cohn and Ruggiero, 2016). This hypothesis is supported by the presence of a prominent outer bar at about $-4 \mathrm{~m}$ depth in 2017 (fig. 8B) that is not present in later survey years. Conversely, a lowering of more than $1 \mathrm{~m}$ of the bed surface over this timeframe near the $-2 \mathrm{~m}$ depth is related to the presence of a bar trough in the 2019 survey that was not present in the 2014 survey. The beaches along Ocean City also gained volume measurably (that is, the volume change is greater than our estimated 

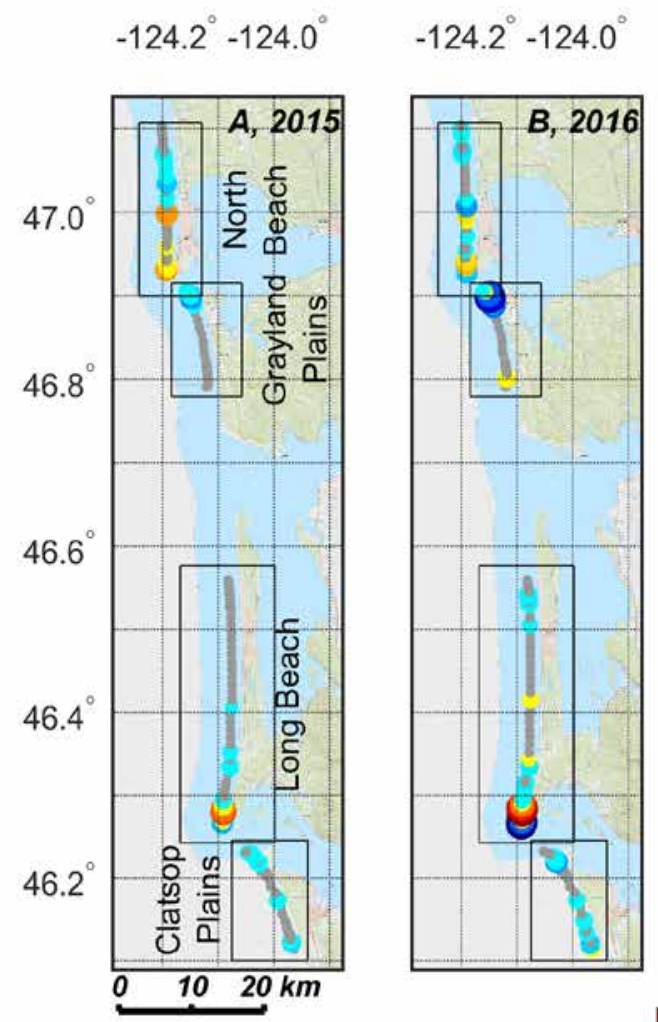

$-124.2^{\circ}-124.0^{\circ}$

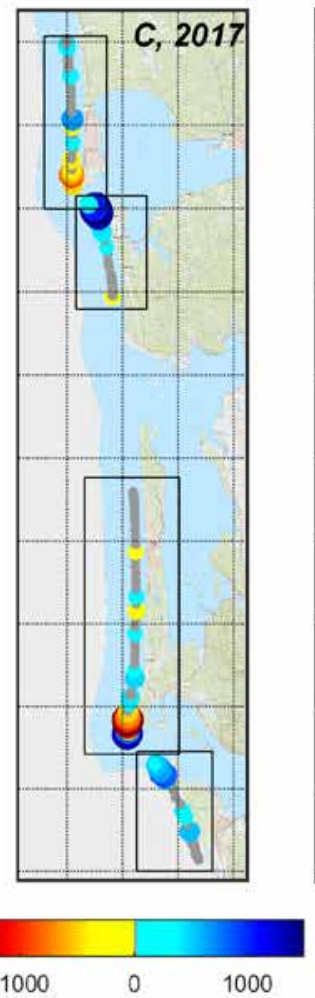

Cum. total volume change $\left(\mathrm{m}^{3} / \mathrm{m}\right)$ $-124.2^{\circ}-124.0^{\circ}$
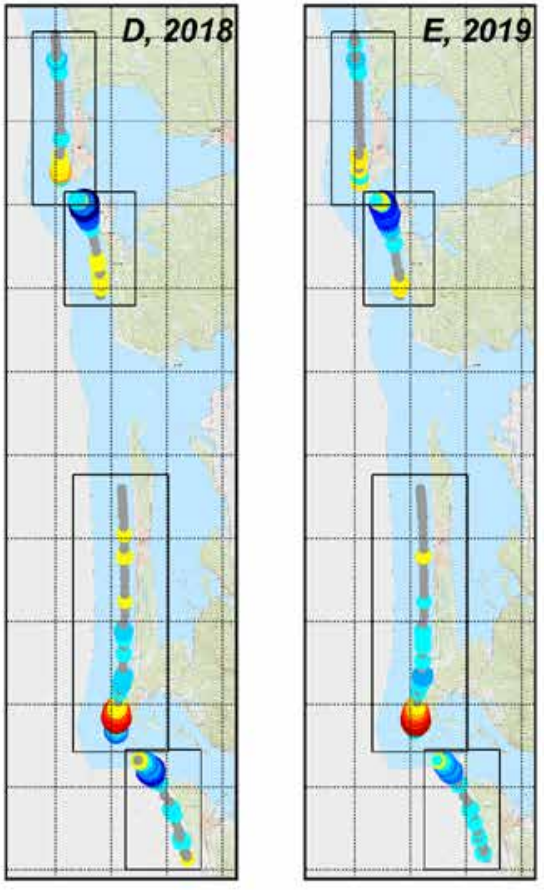

Figure 6. Maps showing cumulative net volume changes (colored dots) for entire profiles in $2015(A), 2016$ $(B), 2017(C), 2018(D)$, and $2019(E)$. Darker gray shading indicated profiles that had volume changes less than estimated uncertainty. Other abbreviations: km, kilometer(s); m, meter(s).

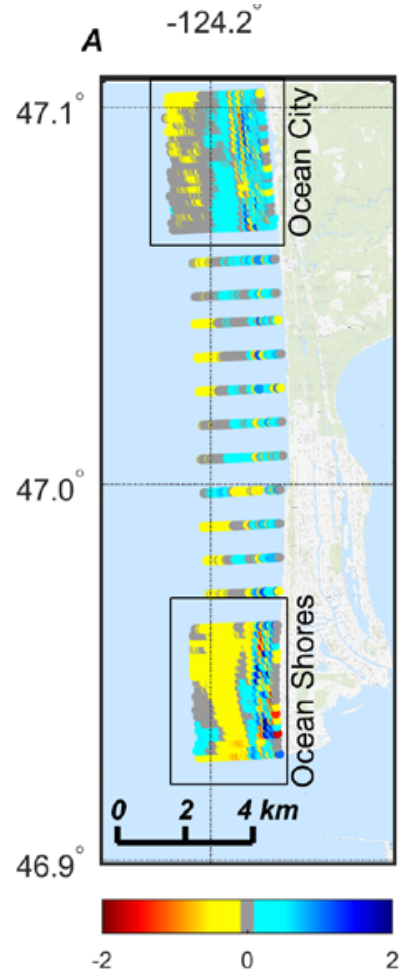

Cum. elevation change (m, 2019-2014)
B

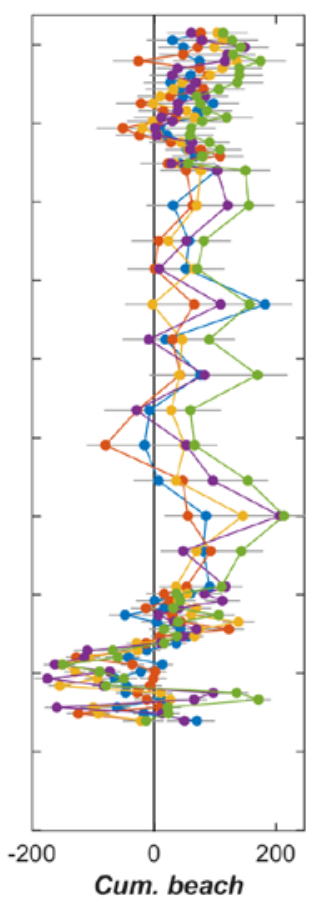

volume change $\left(\mathrm{m}^{3} / \mathrm{m}\right)$
C

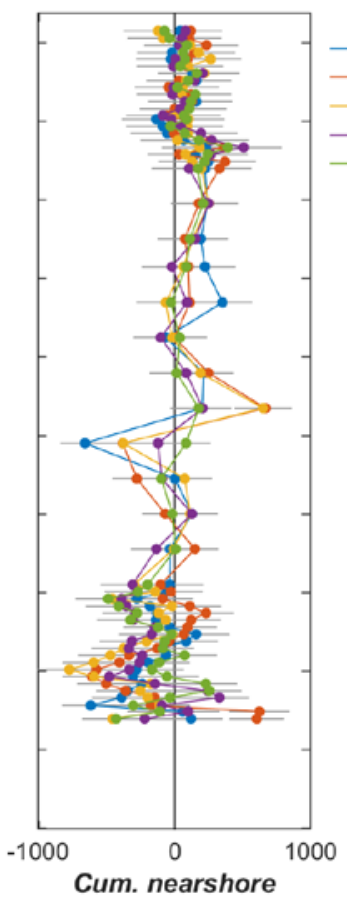

volume change $\left(\mathrm{m}^{3} / \mathrm{m}\right)$
B

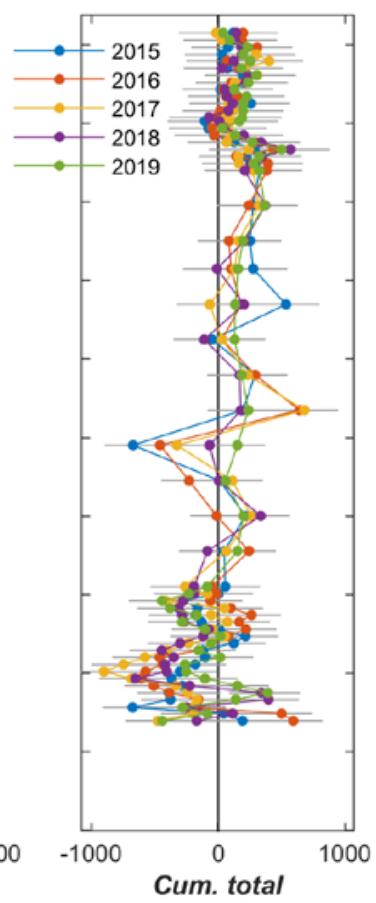

volume change $\left(\mathrm{m}^{3} / \mathrm{m}\right)$
Figure 7. Map showing cumulative elevation changes (A) along North Beach subcell between 2014 and 2019. Also shown are cumulative volume changes for beach $(B)$, nearshore $(C)$, and entire profiles (D) during same time period. Abbreviations: km, kilometer(s); $\mathrm{m}$ meter(s). 


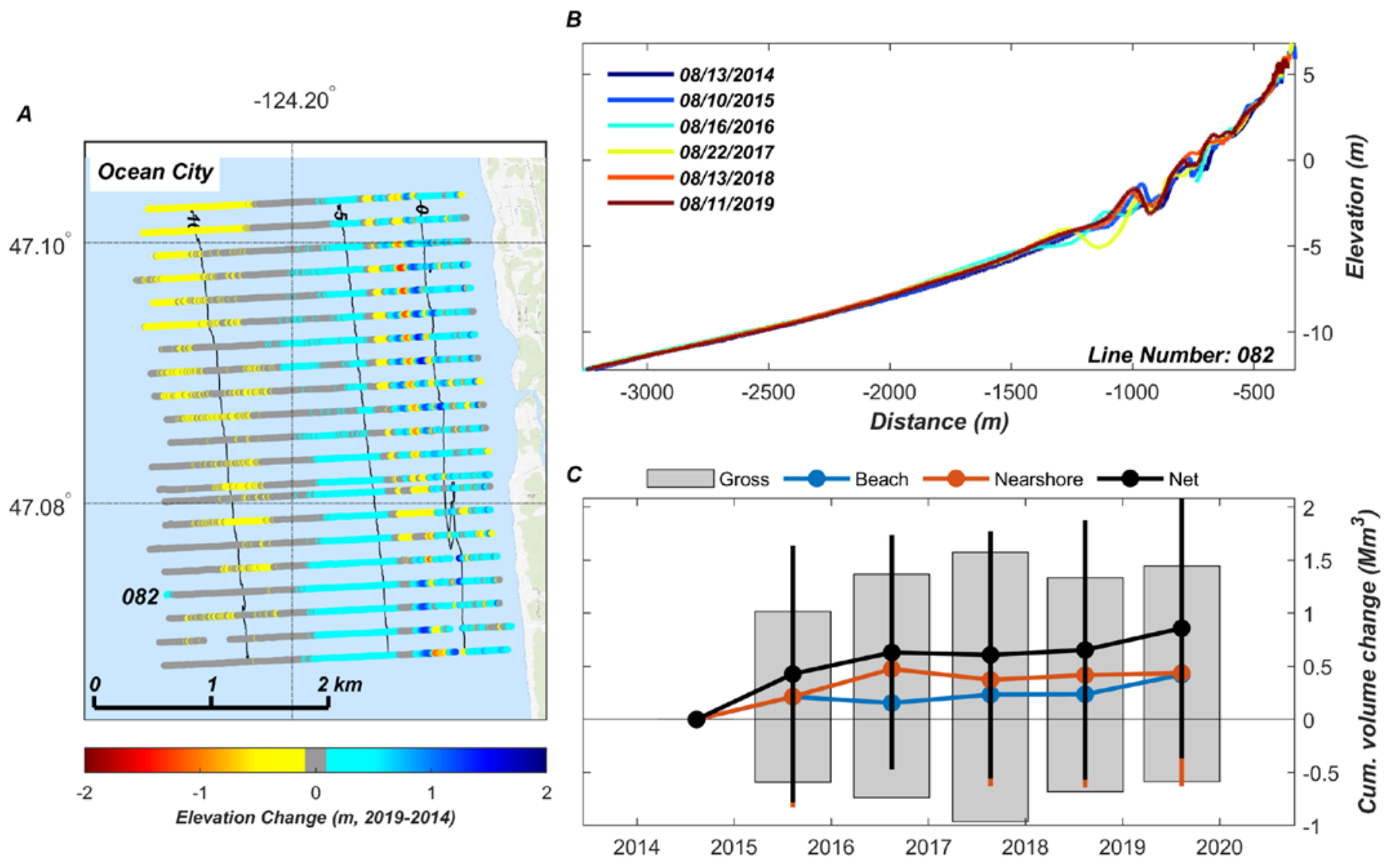

Figure 8. $A$, Map showing cumulative elevation changes between 2014 and 2019 for 0 cean City region within North Beach subcell (see fig. 7 for location); depth contours (5-m interval between -10 and $0 \mathrm{~m}$ ) based on 2014 survey. $B$, Example profile showing changes in beach and nearshore morphology along survey line 082 (location shown in $A$ ). $C$, Time-series plot of volume changes calculated for Ocean City region; net volume changes are provided for beach and nearshore depth zones, as well as net volume changes integrated over entire region. Abbreviations: $\mathrm{km}$, kilometer(s); m, meter(s); $\mathrm{Mm}^{3}$, million cubic meter(s).

uncertainty) across a broad range of elevations, from the lower intertidal zone (near $0 \mathrm{~m}$ ) to near the dune at 5 -m elevation.

Despite the complicated pattern of net volume change in the Ocean Shores region, some notable patterns of erosion and deposition were observed (fig. 9). The shape of the outer shore face between -10 and $-5 \mathrm{~m}$ depth increased in concavity owing to erosion offshore at depths of between -10 and $-7 \mathrm{~m}$, as observed in example profile 010 . Net erosion at this location occurred between 2014 and 2017, and deepening of the trough of a nearshore bar was responsible for a large amount of the volume loss (fig. 9B). The erosional trend in Ocean Shores ended in 2017, and sediment accumulated between 2017 and 2019 , both of which resulting in no significant change for this region during the entire study period. Beach dynamics were quite complicated in the Ocean Shores region, as some profiles (for example, line 010) experienced measurable erosion and about $10 \mathrm{~m}$ of landward movement of the dune face.

\section{Grayland Plains Subcell}

Spatially consistent patterns of erosion and deposition were observed along the Grayland Plains subcell (fig. 10). In the Westport region, sediment accumulation in the nearshore was spatially pervasive, and the magnitude of the gains were large. The largest amount of accumulation observed throughout the CRLC during the monitoring period was observed in the Westport region, at the north end of the Grayland Plains subcell where cumulative profile integrated net volume change between 2014 and 2019 exceeded $1,000 \mathrm{~m}^{3} / \mathrm{m}$ for several profiles (fig. 10D). Despite the strong accumulation pattern in the nearshore and beach at the north end of Westport, the beach in the southern part of Westport eroded. In the Grayland region, at the south end of the Grayland Plains subcell, a large cross-shore exchange signal in volume change was observed whereby the beaches gained volume and the nearshore lost 
$A$

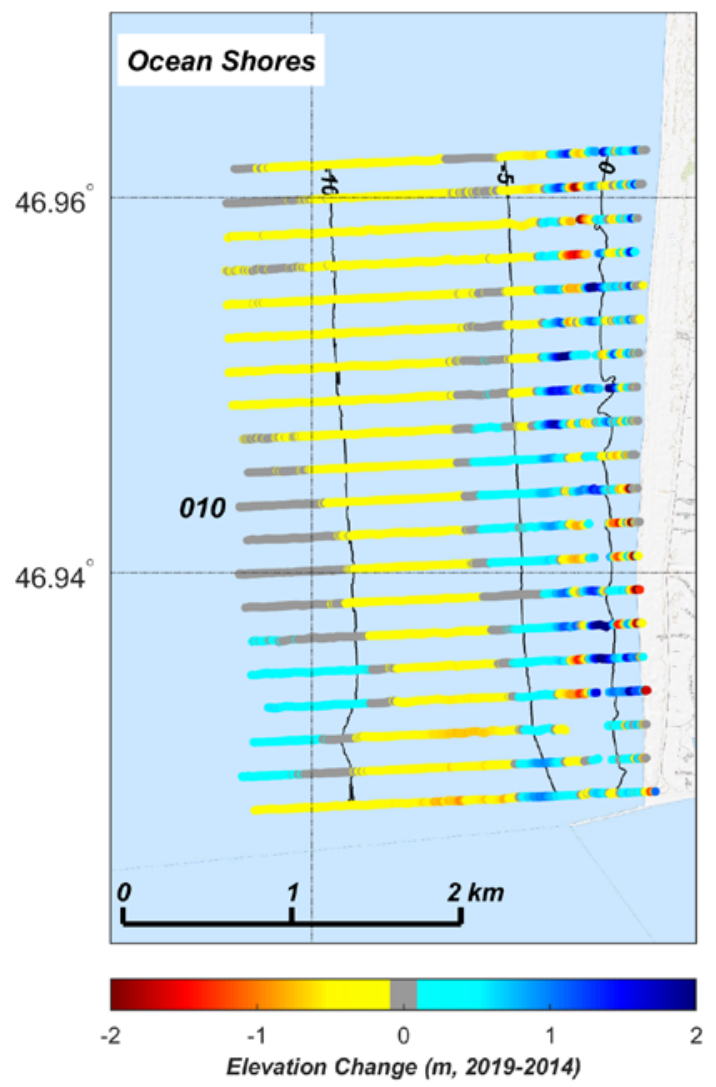

$B$

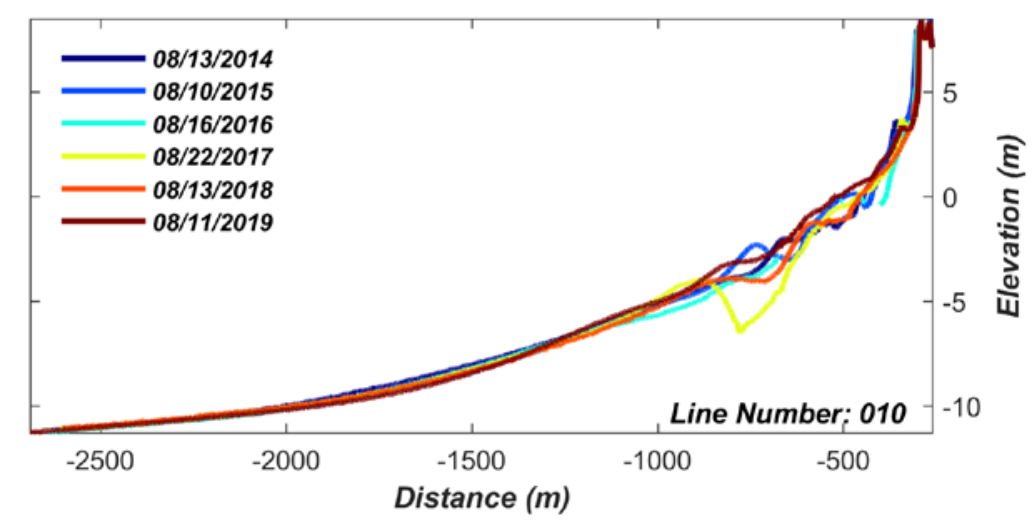

C

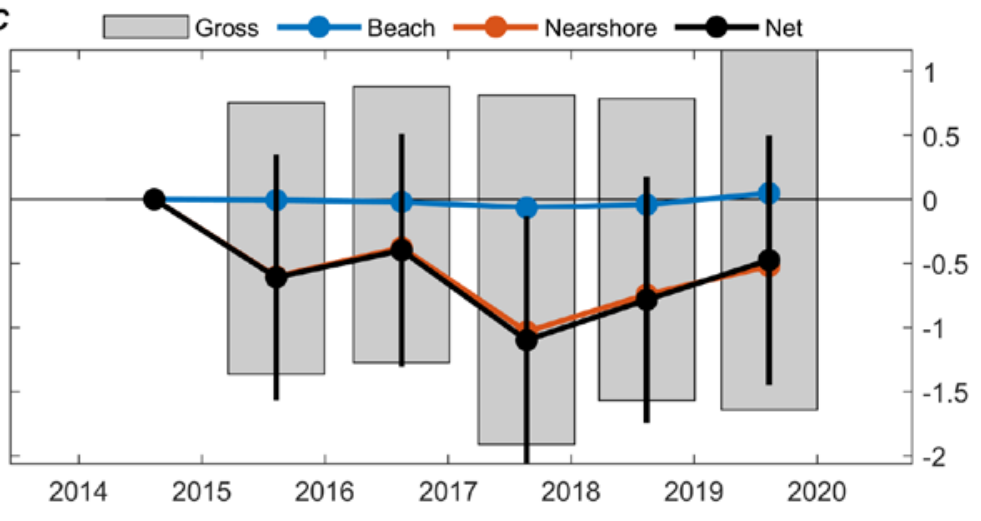

Figure 9. A, Map showing cumulative elevation changes between 2014 and 2019 for Ocean Shores region within North Beach subcell (see fig. 7 for location); depth contours (5-m interval between -10 and $0 \mathrm{~m}$ ) based on 2014 survey. $B$,Example profile showing changes in beach and nearshore morphology along survey line 010 (location shown in A). C, Time-series plot of volume changes calculated for Ocean Shores region; net volume changes are provided for beach and nearshore depth zones, as well as net volume changes integrated over entire region. Abbreviations: km, kilometer(s); m, meter(s); $\mathrm{Mm}^{3}$, million cubic meter(s). 

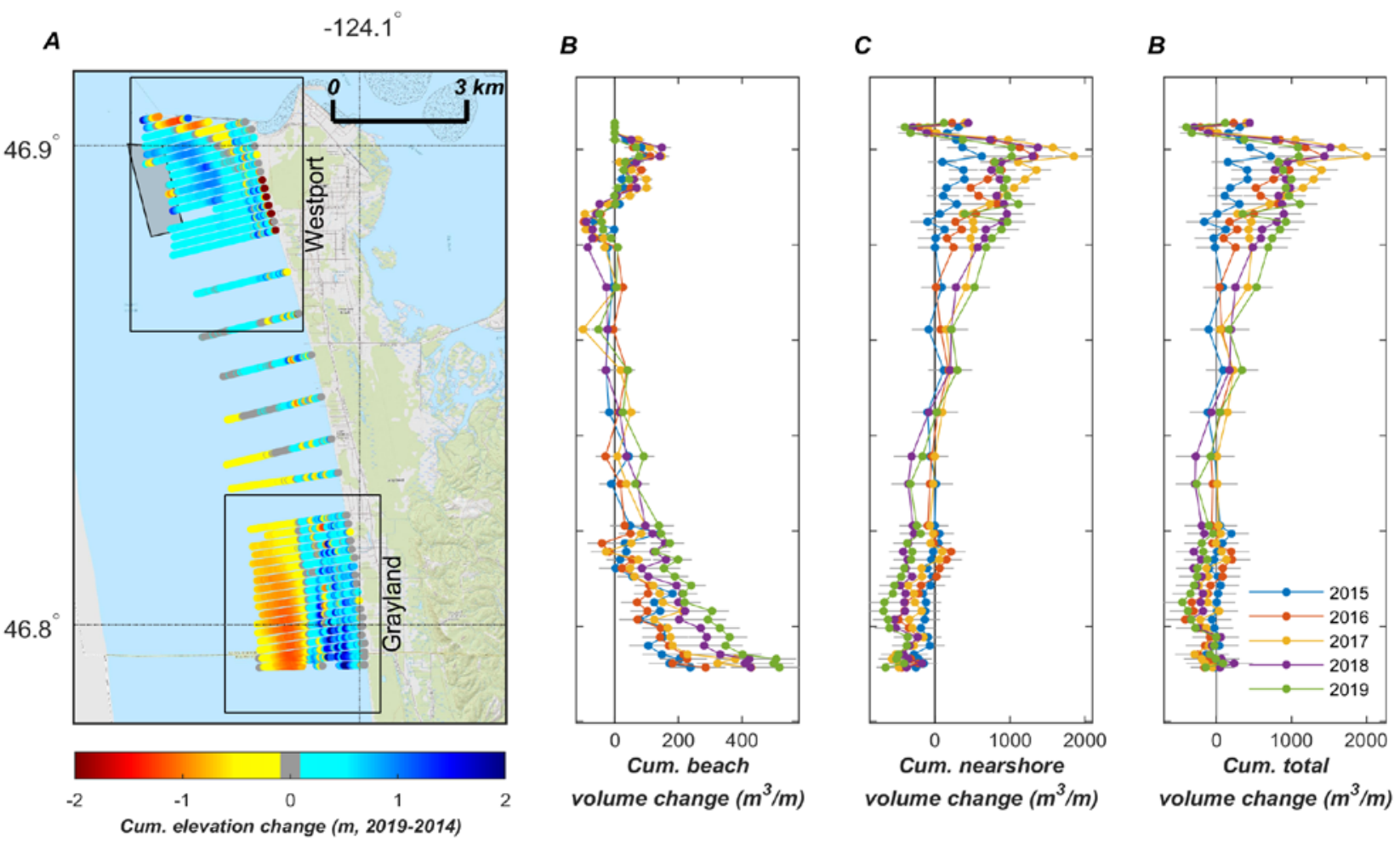

Figure 10. Map showing cumulative elevation changes $(A)$ along Grayland Plains subcell between 2014 and 2019; gray-filled box shows nearshore dredge-placement area offshore of Westport. Also shown are cumulative volume changes for beach $(B)$, nearshore $(C)$, and entire profiles $(D)$ during same time period. Abbreviations: km, kilometer(s); $\mathrm{m}$, meter(s).

volume. The net result was a measurable erosion signal along parts of the Grayland region, the cumulative profile integrated net erosion being as high as $450 \mathrm{~m}^{3} / \mathrm{m}$.

Most of the net volume gain in the Westport region of the Grayland Plains subcell is due to accumulation across the lower shoreface (fig. 11). Elevation change in excess of $1 \mathrm{~m}$ was observed across a broad depth zone between the end of the profile (at $-10 \mathrm{~m}$ depth) to approximately $-5 \mathrm{~m}$ depth. Accumulation in the lower shoreface appears to be enhanced onshore of the nearshore dredge-placement site, and unusual dynamics at the end of the profiles seem to capture areas of active dredge placement. The rate of sediment accumulation in the nearshore was steady between 2014 and 2017, after which no further net volume gain, or potentially a net volume loss (within the measurement uncertainty), was observed. The observed beach erosion at the south end of Westport occurred in the upper beach and dunes where cumulative elevation change in excess of $-3 \mathrm{~m}$ was observed. The dune crest retreated approximately $20 \mathrm{~m}$ landward, and its height reduced by approximately $1 \mathrm{~m}$. Despite volume losses to the dune, nearly no net volume changes to the beach compartment occurred within Westport during the measurement period (fig. 11C).

Throughout the Grayland region within the Grayland Plains subcell, rotation of the shoreface was observed around a pinch point at approximately $-5 \mathrm{~m}$ depth (fig. 12). The shoreface rotation, which has been relatively consistent throughout the monitoring period, has led to increased concavity and volume loss on the lower shoreface. Meanwhile, between the shoreline and dune toe across the wide beaches of Grayland region, a broad area of accumulation was observed. The average elevation of the beach increased by approximately $1 \mathrm{~m}$, and the location of the 3 -m elevation contour prograded seaward about $40 \mathrm{~m}$, resulting in net beach volume gain that about matched the loss in the nearshore. The combined effect of nearshore erosion and beach accumulation resulted in minimal cumulative net volume losses during the study period integrated across Grayland region. 
$A$

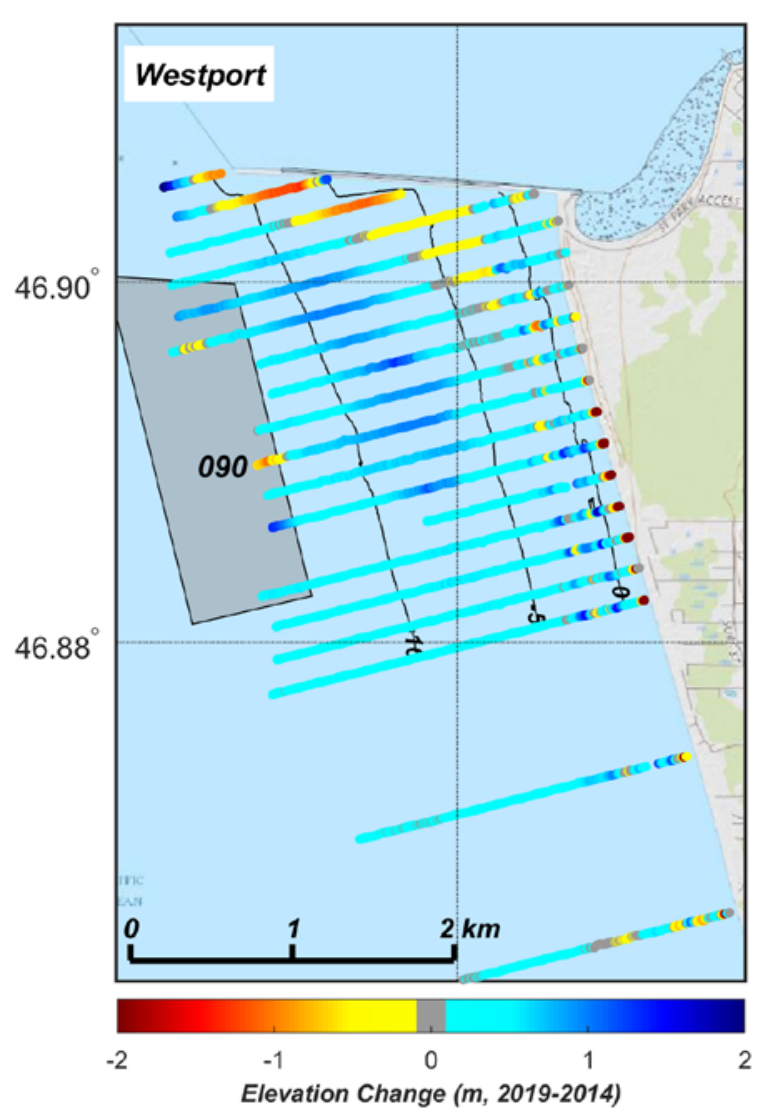

$B$
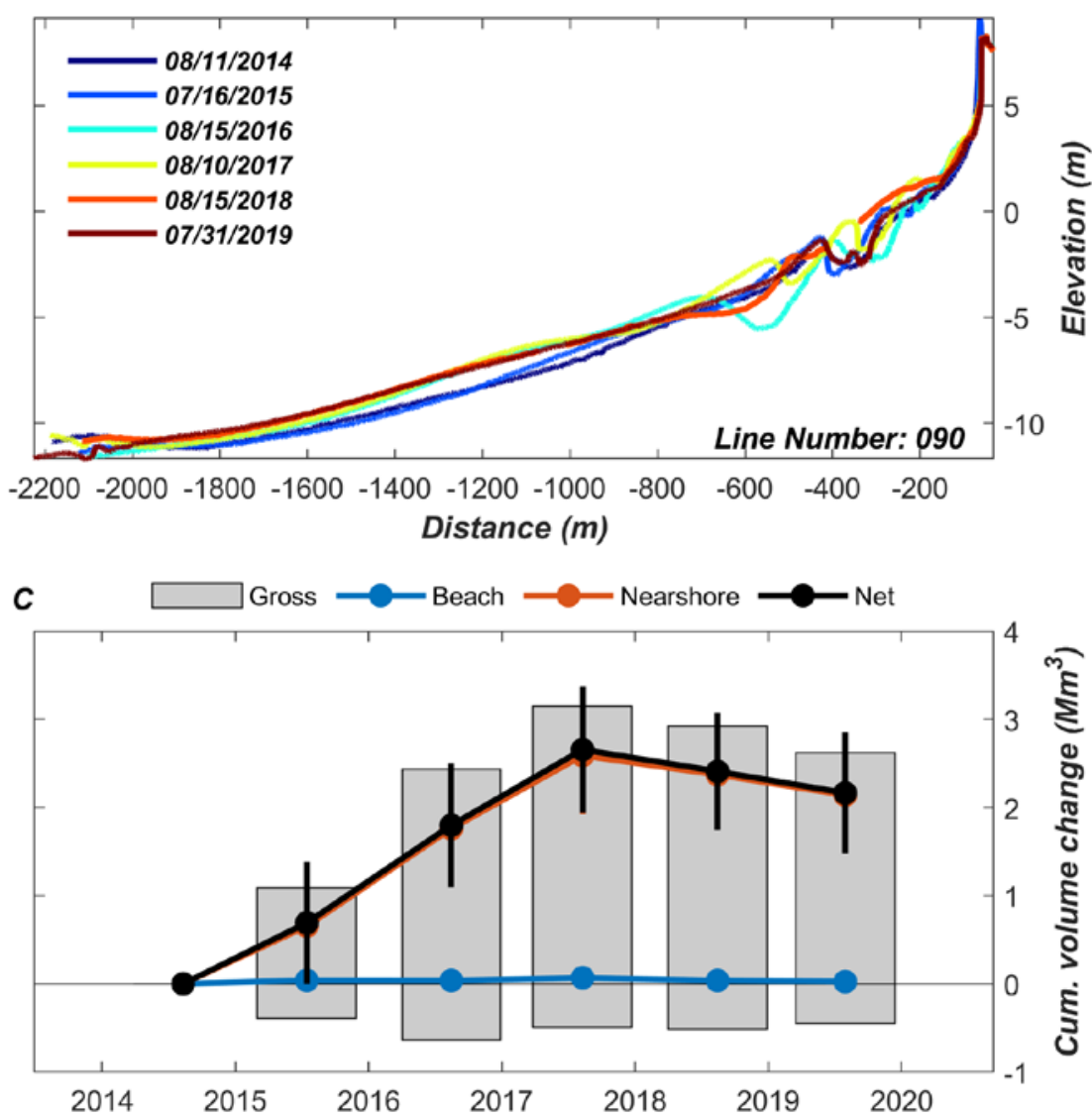

Figure 11. A, Map showing cumulative elevation changes between 2014 and 2019 for Westport region within Grayland Plains subcell (see fig. 10 for location); depth contours (5-m interval between -10 and $0 \mathrm{~m}$ ) based on 2014 survey. Gray-filled box shows nearshore dredge-placement area. $B$, Example profile showing changes in beach and nearshore morphology along survey line 090 (location shown in $A$ ). C, Time-series plot of volume changes calculated for Westport region; net volume changes are provided for beach and nearshore depth zones, as well as net volume changes integrated over entire region. Abbreviations: $\mathrm{km}$, kilometer(s); $\mathrm{m}$, meter(s); $\mathrm{Mm}^{3}$, million cubic meter(s). 
A

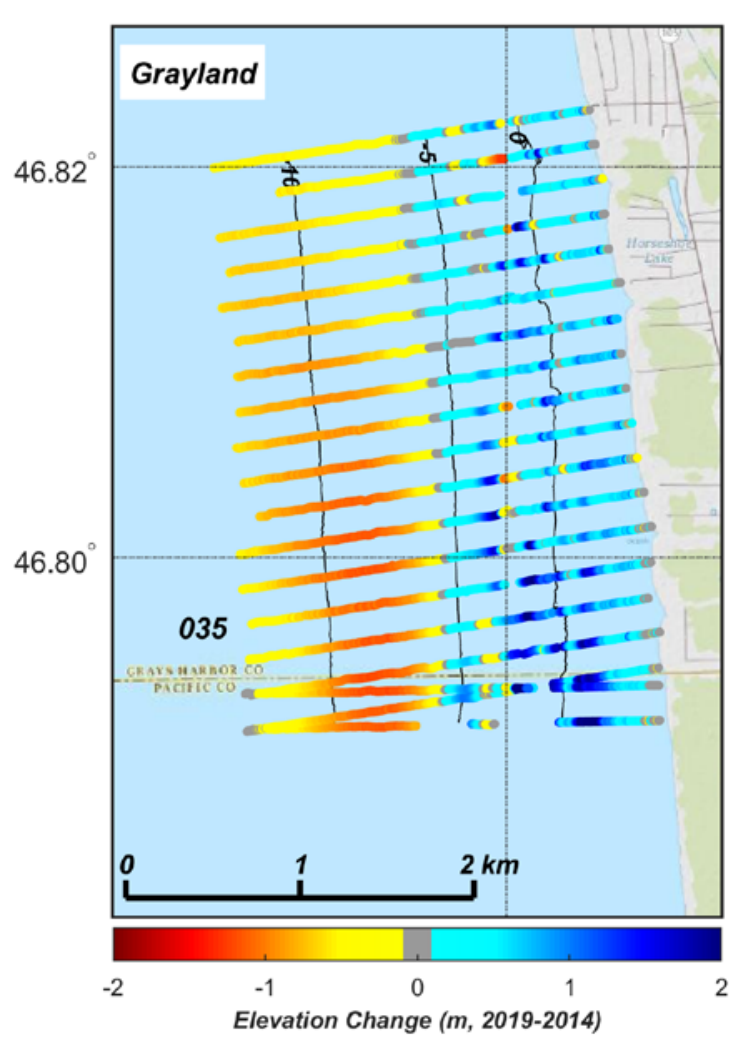

B

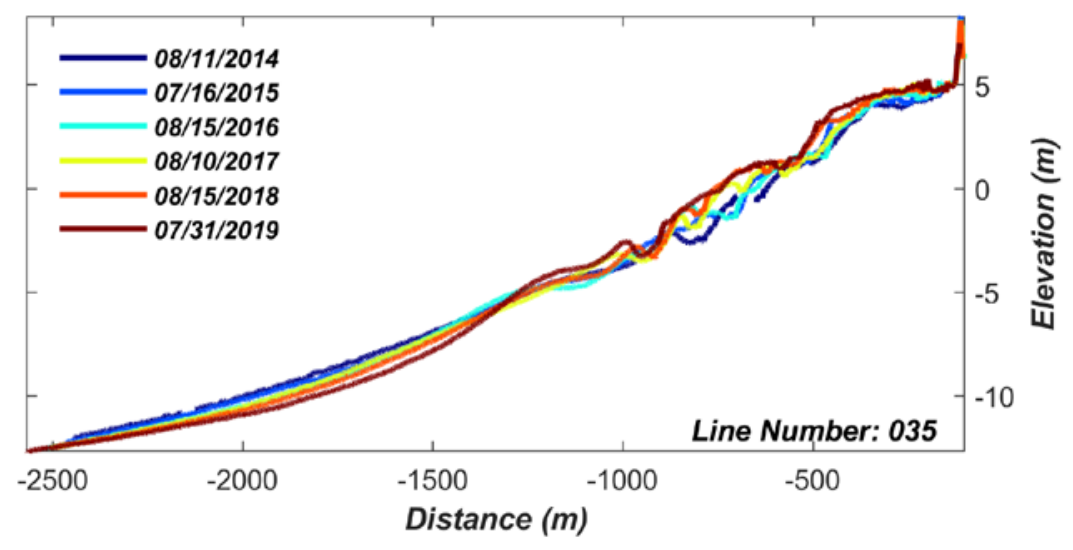

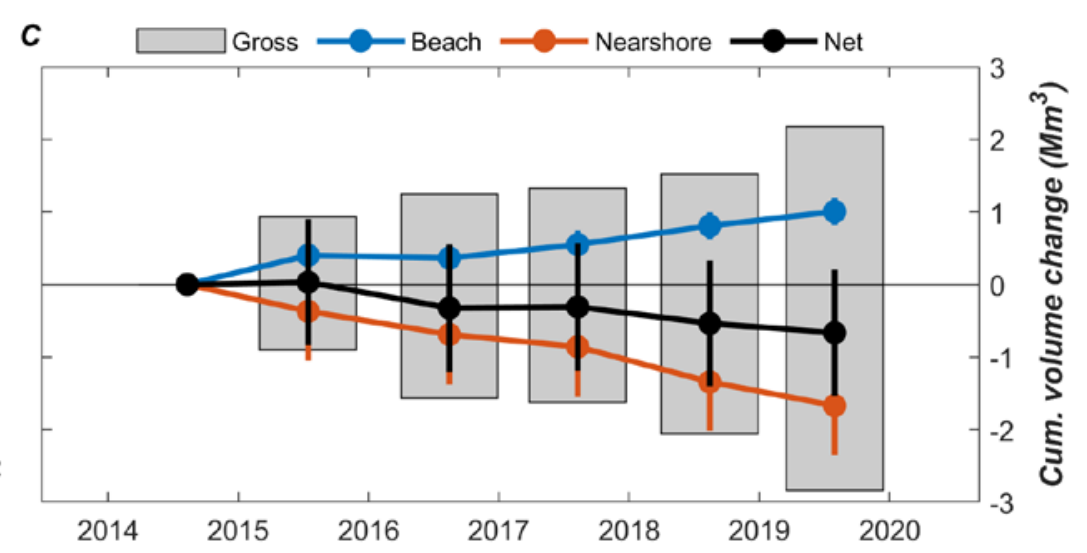

Figure 12. A, Map showing cumulative elevation changes between 2014 and 2019 for Grayland region within Grayland Plains subcell (see fig. 10 for location); depth contours (5-m interval between -10 and $0 \mathrm{~m}$ ) based on 2014 survey. $B$, Example profile showing changes in beach and nearshore morphology along survey line 035 (location shown in $A$ ). $C$, Time-series plot of volume changes calculated for Grayland region; net volume changes are provided for beach and nearshore depth zones, as well as net volume changes integrated over entire region. Abbreviations: km, kilometer(s); $\mathrm{m}$, meter(s); $\mathrm{Mm}^{3}$, million cubic meter(s). 


\section{Long Beach Subcell}

The most severe erosion throughout the study area was observed along the southern part of the Long Beach subcell (fig. 13) at Benson Beach. Beach erosion peaked in 2017 in the area between the Columbia River North Jetty and North Head. The extreme beach erosion was also accompanied by erosion in the nearshore, with profile-averaged net volume losses within Benson Beach as high as $1,600 \mathrm{~m}^{3} / \mathrm{m}$ during the 5 -year study period. However, at the southernmost part of Benson Beach (immediately adjacent to the Columbia River mouth where the survey profiles intersect the North Jetty), accumulation in the nearshore resulted in net accretion. North of Benson Beach, the beaches of the Long Beach peninsula accumulated sediment measurably, whereas volume changes in the nearshore were minimal.
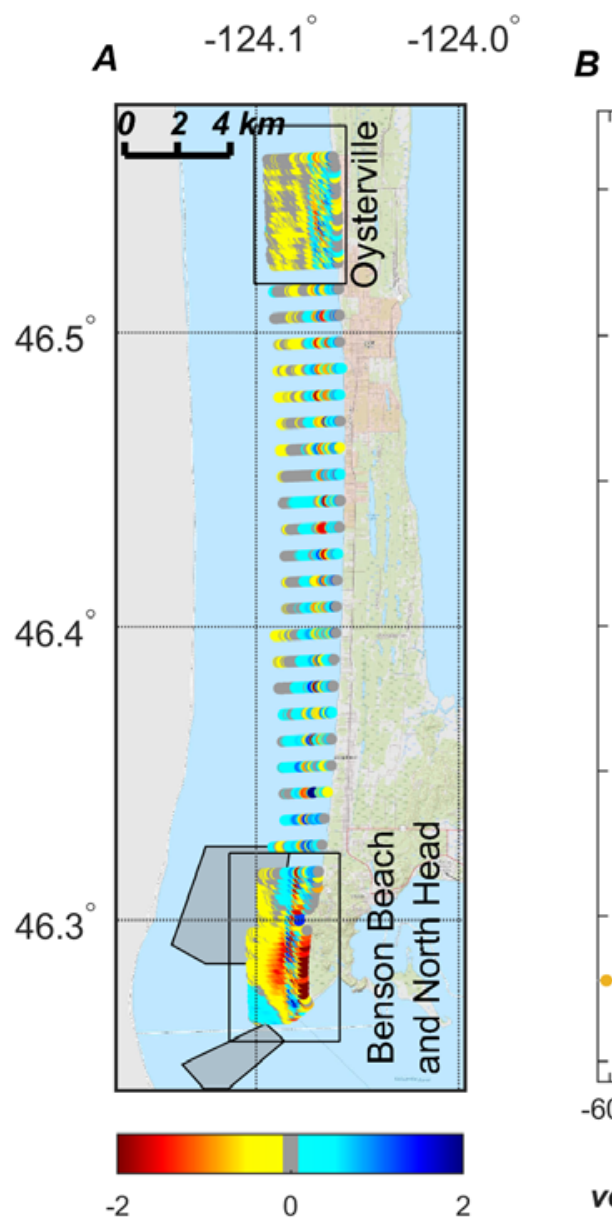

Cum. elevation change ( $m, 2019-2014)$
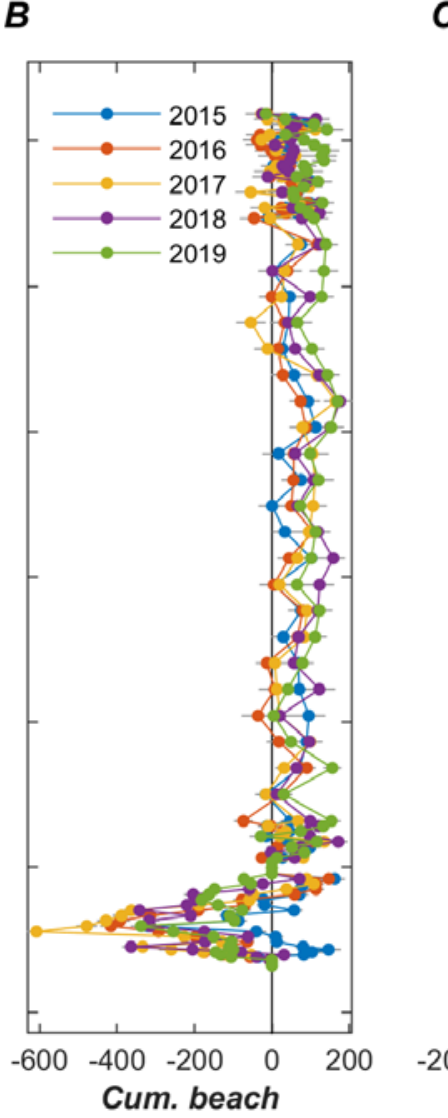

volume change $\left(\mathrm{m}^{3} / \mathrm{m}\right)$
C

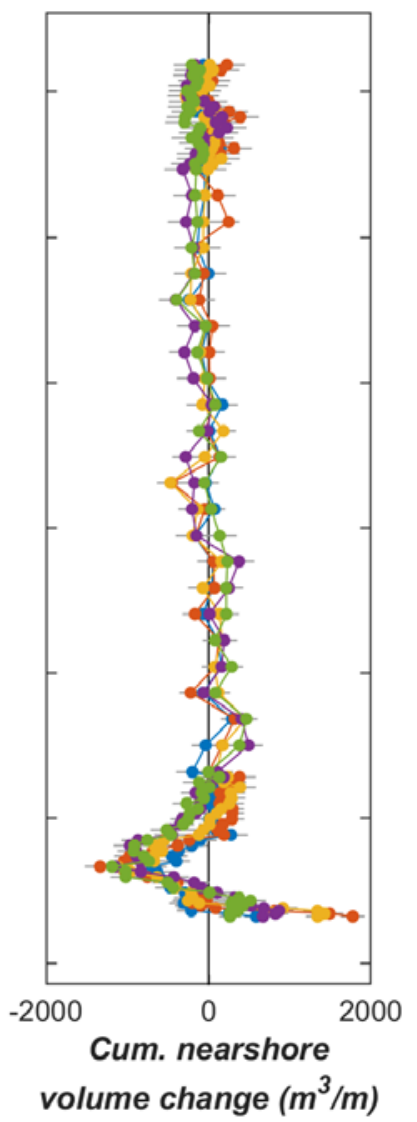

D

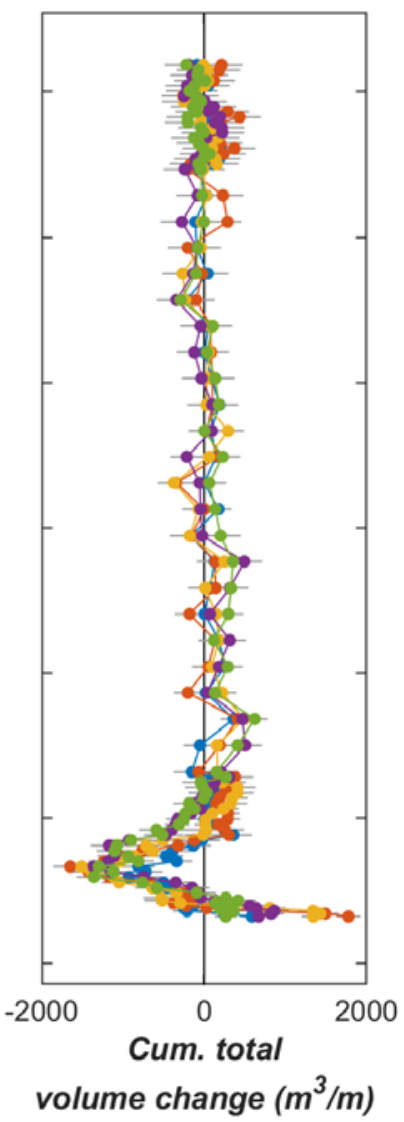

Figure 13. Map showing cumulative elevation changes $(A)$ along Long Beach subcell between 2014 and 2019; gray-filled boxes show nearshore dredge-placement areas offshore of Benson Beach and North Head. Also shown are cumulative volume changes for beach $(B)$, nearshore $(C)$, and entire profiles $(D)$ during same time period. Abbreviations: $\mathrm{km}$, kilometer(s); m, meter(s). 
A broad zone of small but measurable erosion was observed throughout the outer part of the nearshore zone in the Oysterville region (fig. 14), at the north end of the Long Beach subcell. Changes in the size and position of sandbars in the inner nearshore at depths between -5 and $-1 \mathrm{~m}$ resulted a complicated pattern of erosion and deposition. Cumulative net volume change in the nearshore did not generally exceed the measurement uncertainty over the monitoring time period.
Accumulation was observed on the beaches of the Oysterville region, with positive elevation changes occurring on the beach foreshore between 3- and 7-m elevations. Although little measurable elevation change occurred above $7 \mathrm{~m}$ and the position of the primary dune crest was stable, the 3-m elevation contour prograded seaward an average of about $25 \mathrm{~m}$.

Closely spaced topographic and bathymetric profiles were collected on both sides of North Head, including for the
$A$

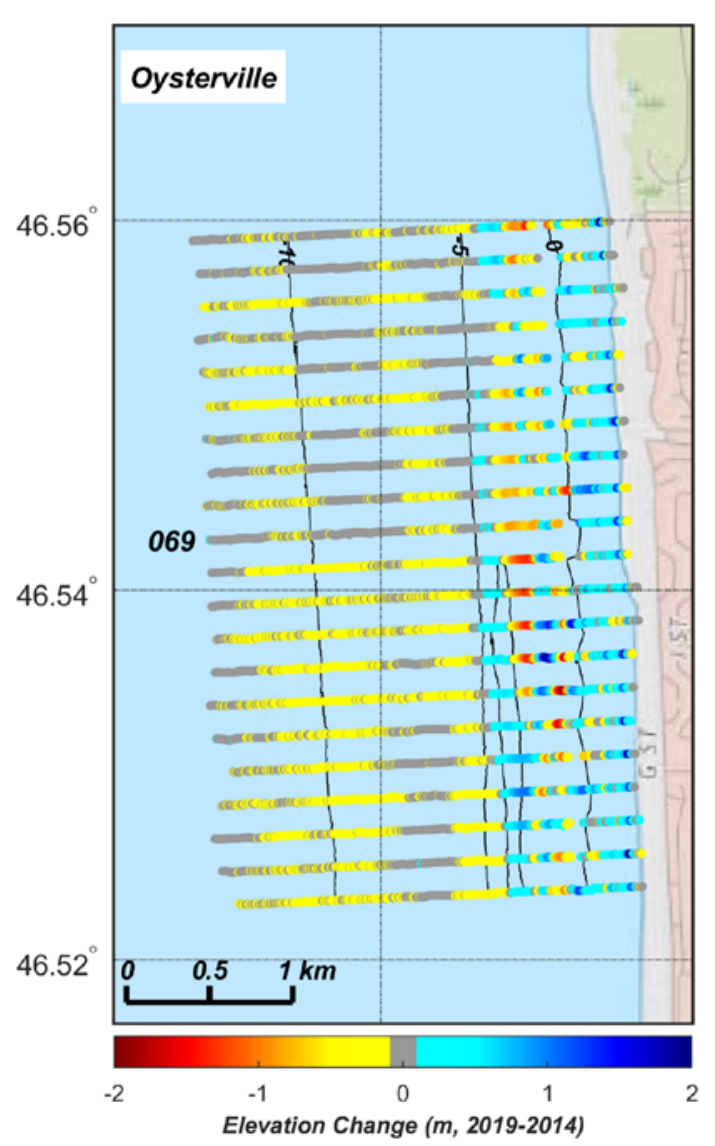

B

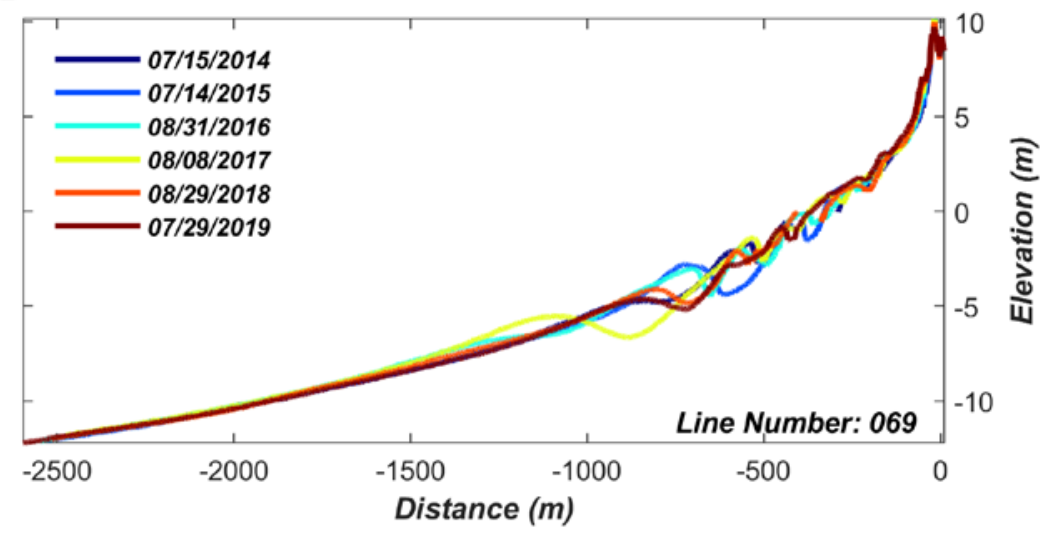

c

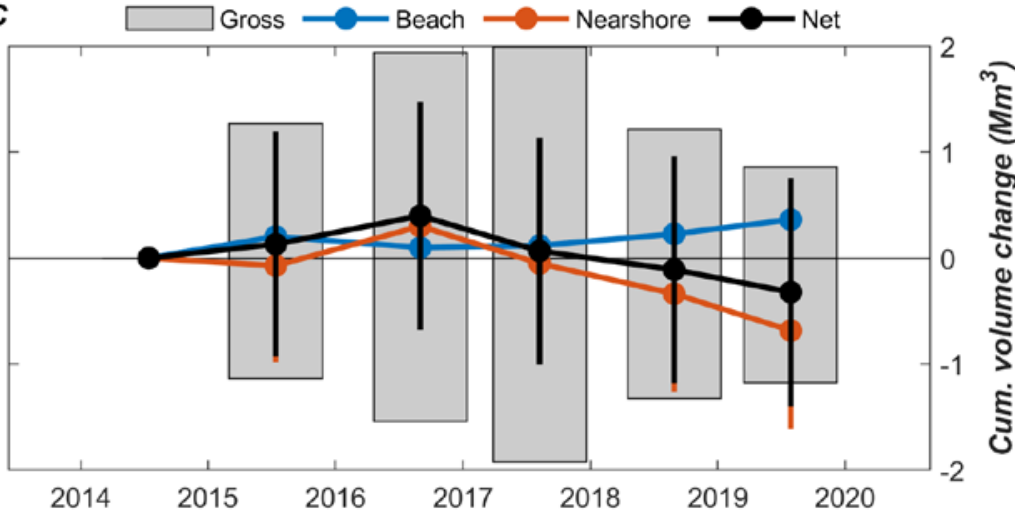

Figure 14. A, Map showing cumulative elevation changes between 2014 and 2019 for Oysterville region within Long Beach subcell (see fig. 13 for location); depth contours (5-m interval between -10 and $0 \mathrm{~m}$ ) based on 2014 survey. $B$, Example profile showing changes in beach and nearshore morphology along survey line 069 (location shown in $A$ ). $C$, Time-series plot of volume changes calculated for Oysterville region; net volume changes are provided for beach and nearshore depth zones, as well as net volume changes integrated over entire region. Abbreviations: km, kilometer(s); m, meter(s); $\mathrm{Mm}^{3}$, million cubic meter(s). 
erosional region of Benson Beach. North of North Head, the dynamics of a pronounced outer bar drove observed changes in elevation and sand volume in the nearshore (fig. 15). Alternating erosion and deposition across the nearshore reflected interannual variations in the position of the outer bar crest and trough. Measurable net accumulation in the nearshore peaked in 2017, after which erosion occurred, and no significant net change in nearshore sand volume could be detected by 2019. After 2016, the beaches north of North Head began to gain volume, and net deposition was significant $\left(111,000 \pm 35,000 \mathrm{~m}^{3}\right)$ by 2019 .

Central Benson Beach, south of North Head at the south end of the Long Beach peninsula, experienced net erosion across the entire shoreface (fig. 16). Measurable erosion

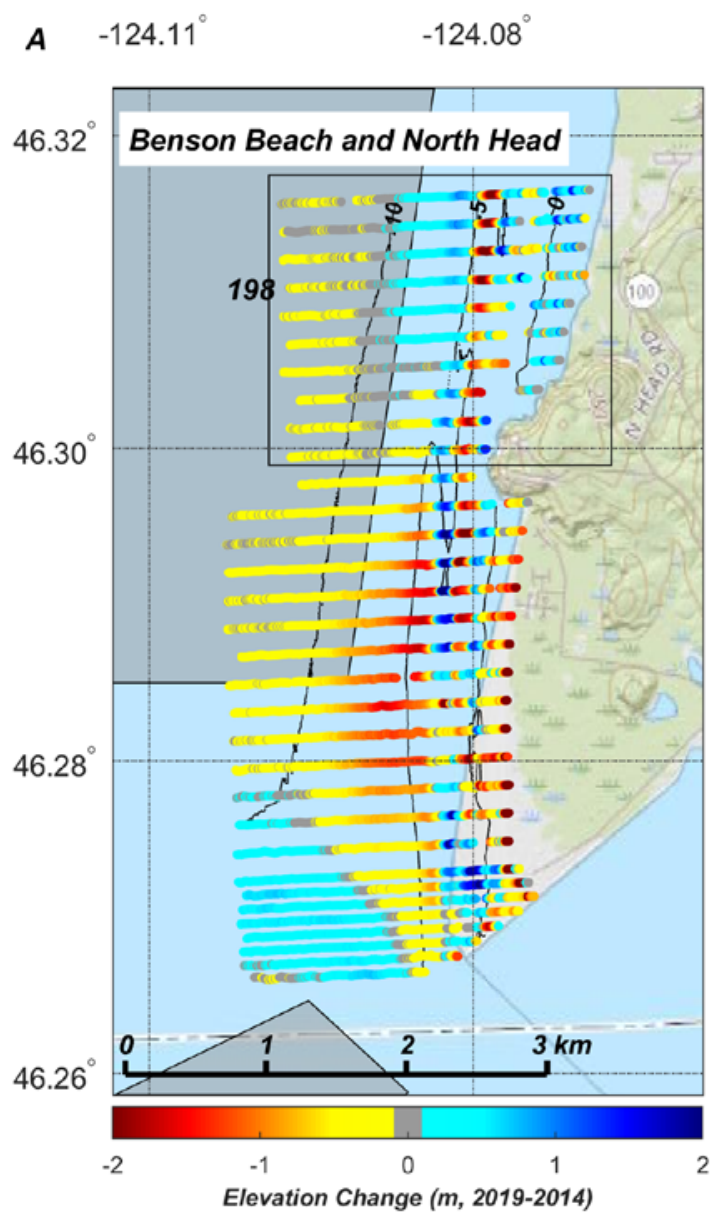

B
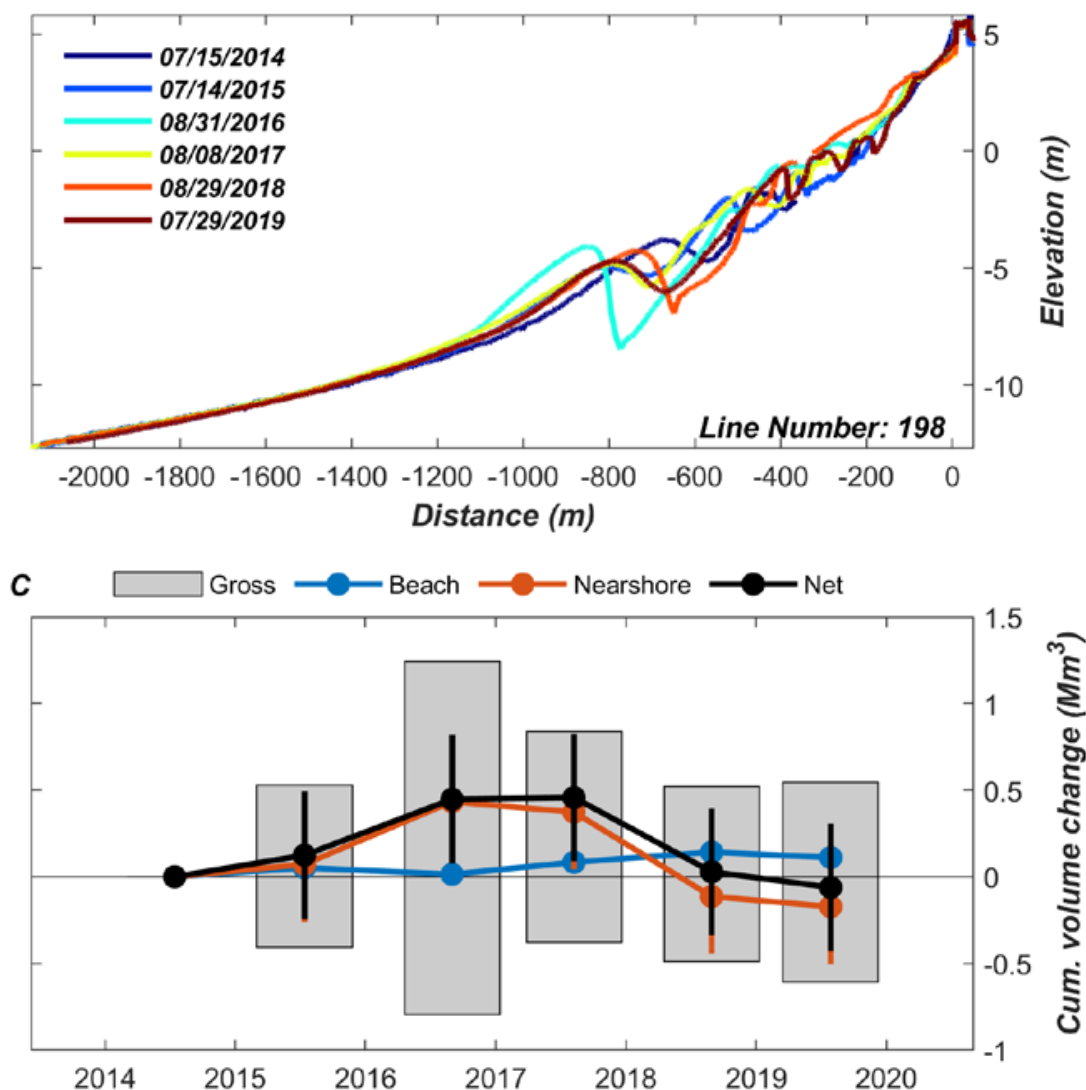

Figure 15. A, Map showing cumulative elevation changes between 2014 and 2019 for Benson Beach and North Head regions within Long Beach subcell (see fig. 13 for location); depth contours (5-m interval between -10 and $0 \mathrm{~m}$ ) based on 2014 survey. Black line outlines profiles used to calculate net volume changes in North Head region. Gray-filled boxes show North Head study area (northwest corner) and Columbia River Shallow Water Site (southwest corner) dredge-placement areas. $B$, Example profile showing changes in beach and nearshore morphology along survey line 198 (location shown in A). C, Time-series plot of volume changes calculated for North Head region; net volume changes are provided for beach and nearshore depth zones, as well as net volume changes integrated over entire region. Abbreviations: $\mathrm{km}$, kilometer(s); $\mathrm{m}$, meter(s); $\mathrm{Mm}^{3}$, million cubic meter(s). 
extended from the seaward extents of many of the profiles and continued across the shoreface to the beach, where the crest of the dune retreated landward roughly $50 \mathrm{~m}$, and the elevation of the dune crest lowered more than $1 \mathrm{~m}$ between 2014 and 2019. Accumulation on the beach alleviated some erosion in recent years, although net volume loss on the beach was ubiquitous throughout the Benson Beach region during the monitoring period. At the southernmost extent of Benson Beach, an area of net accumulation was observed in the nearshore from the seaward extent of the profile to a depth of about $-5 \mathrm{~m}$. The area of nearshore accumulation is immediately adjacent to the Columbia River Shallow Water Site, an active dredge-placement area.
A

$-124.11^{\circ}$

$-124.08^{\circ}$

$46.32^{\circ}$

$46.26^{\circ}$

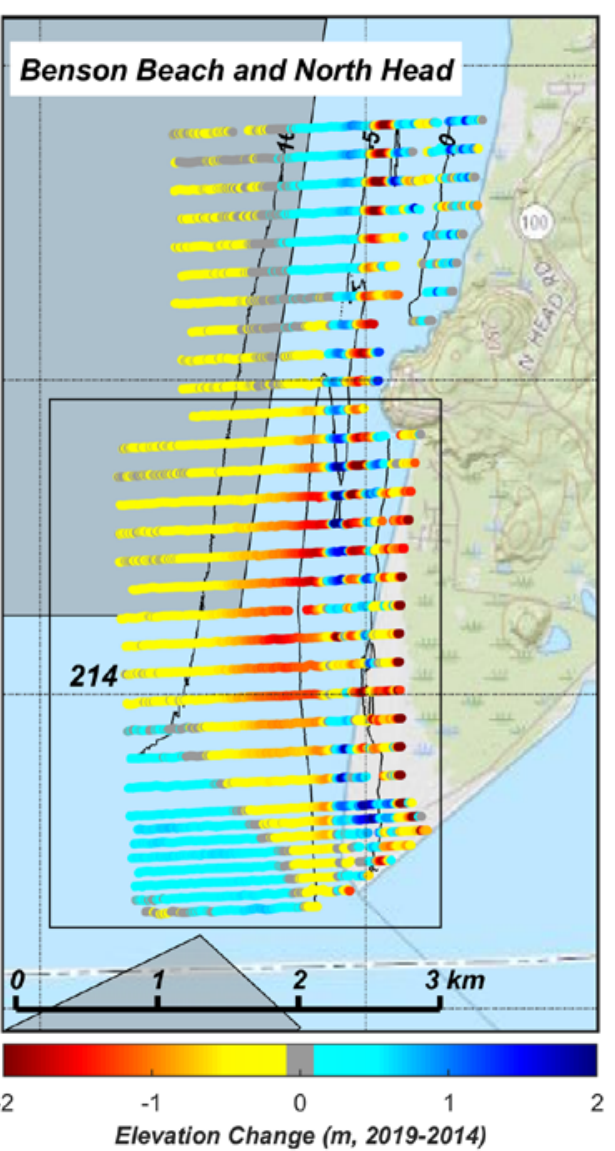

B

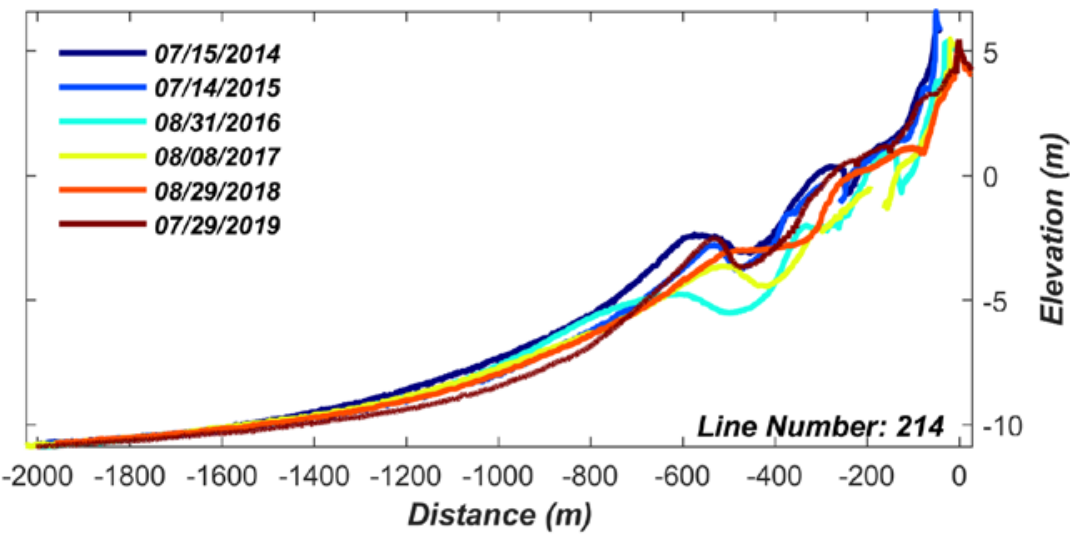

C

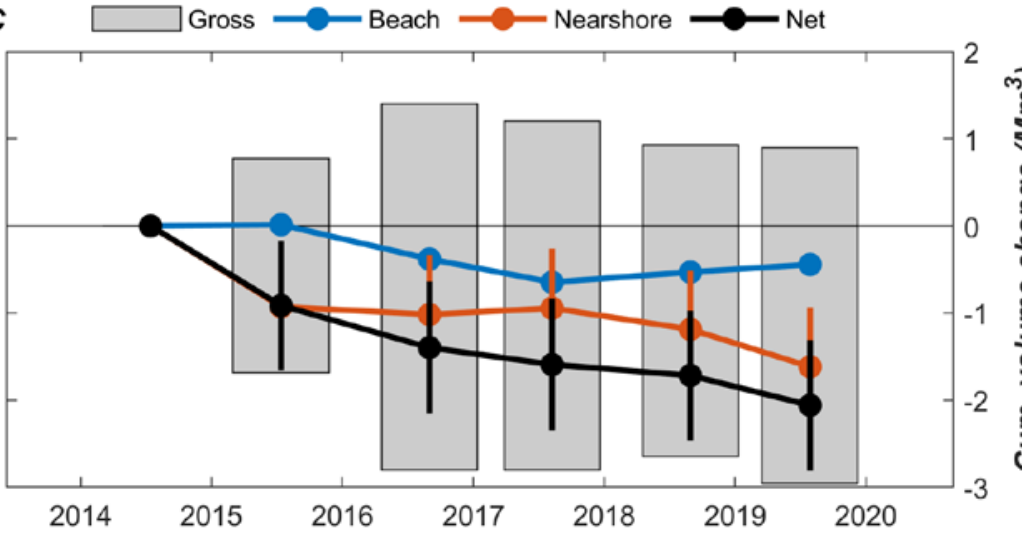

Figure 16. A, Map showing cumulative elevation changes between 2014 and 2019 for Benson Beach and North Head regions within Long Beach subcell (see fig. 13 for location); depth contours (5-m interval between -10 and $0 \mathrm{~m}$ ) based on 2014 survey. Black line outlines profiles used to calculate net volume changes in Benson Beach region. Gray-filled boxes show North Head study area (northwest corner) and Columbia River Shallow Water Site (southwest corner) dredgeplacement areas. $B$, Example profile showing changes in beach and nearshore morphology along survey line 214 (location shown in A). C, Time-series plot of volume changes calculated for Benson Beach region; net volume changes are provided for beach and nearshore depth zones, as well as net volume changes integrated over entire region. Abbreviations: $\mathrm{km}$, kilometer(s); m, meter(s); $\mathrm{Mm}^{3}$, million cubic meter(s). 


\section{Clatsop Plains Subcell}

Very little net erosion was observed along the Clatsop Plains subcell. Only one profile (out of the 48 surveyed and analyzed) in the Clatsop Plains subcell experienced cumulative net erosion above the measurement uncertainty between 2014 and 2019. At South Jetty, a large quantity of sediment deposited in the beach and nearshore (fig. 17).
Farther south in the Camp Rilea region, deposition was observed on the beach, whereas changes in the nearshore were within the measurement uncertainty. The net result was no net measurable change in sediment volume along the southern part of the Clatsop Plains subcell.

Most of the observed net volume change in the South Jetty region was due to a relatively thin $(<0.5 \mathrm{~m})$ layer of sediment accumulation that spread throughout the nearshore
$\boldsymbol{A}$

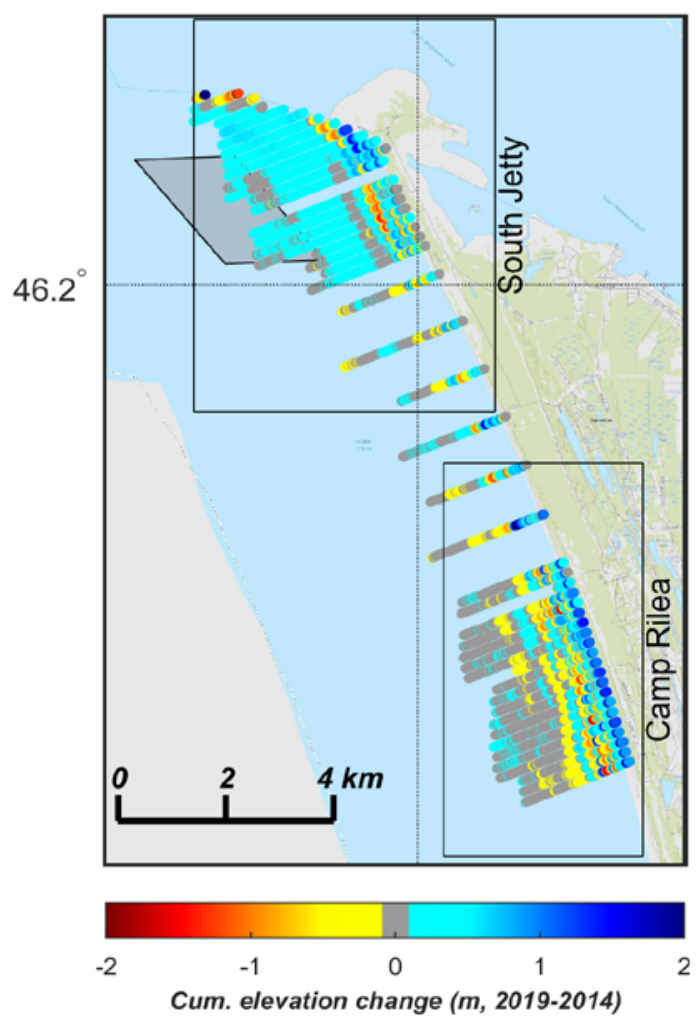

B

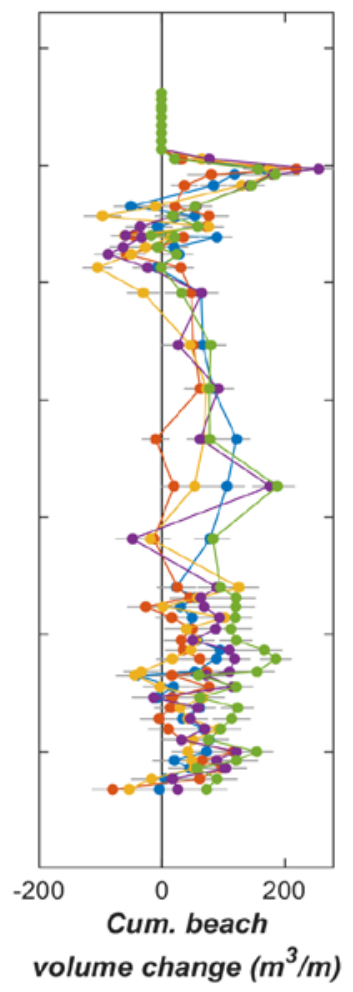

$C$

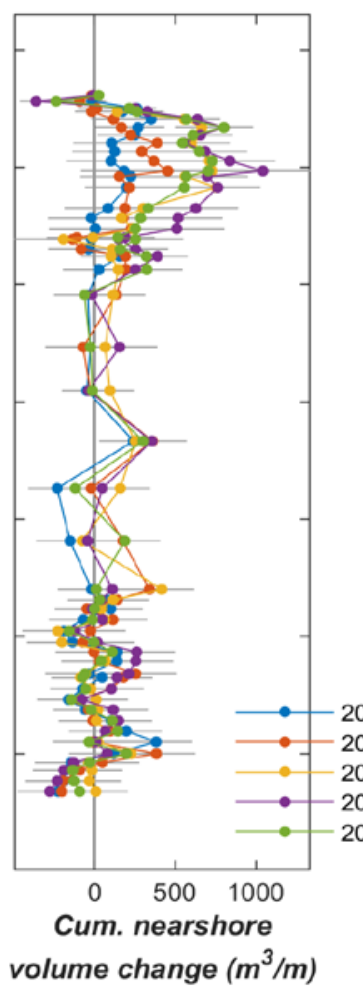

D

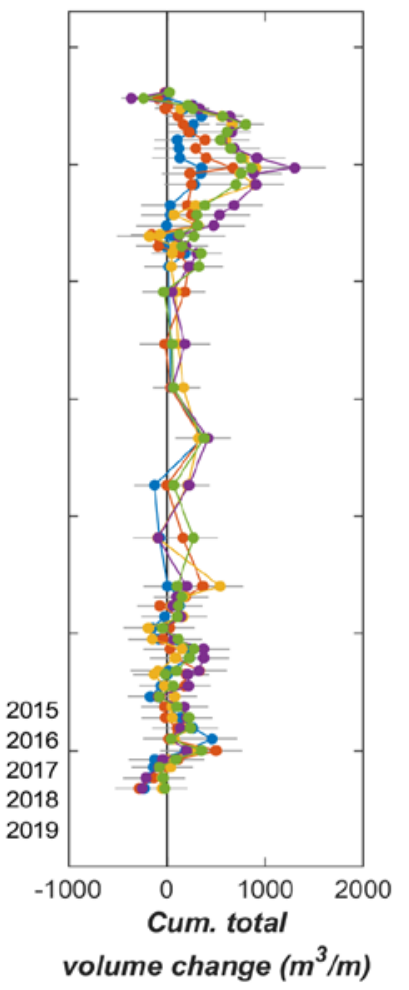

Figure 17. Map showing cumulative elevation changes $(A)$ along Clatsop Plains subcell between 2014 and 2019; gray-filled box shows nearshore dredge-placement area offshore of South Jetty. Also shown are cumulative volume changes for beach $(B)$, nearshore $(C)$, and entire profiles $(D)$ during same time period. Abbreviations: $\mathrm{km}$, kilometer(s); $\mathrm{m}$, meter(s). 
(fig. 18). Unlike the pattern observed in the Wesport region, sediment accumulation does not appear to be enhanced onshore of the South Jetty nearshore dredge-placement area. Some erosion was observed along the South Jetty, as well as in a narrow band along the inner nearshore zone at depths of between -5 and $-2 \mathrm{~m}$. The beaches also gained sediment volume in the South Jetty region, especially to the north, in close proximity to the base of South Jetty.

Bar dynamics in the Camp Rilea region of the Clatsop Plains subcell resulted in a complicated pattern of alternating erosion and deposition in the nearshore zone (fig. 19). A prominent outer bar was present in 2014 and again in 2019,

B
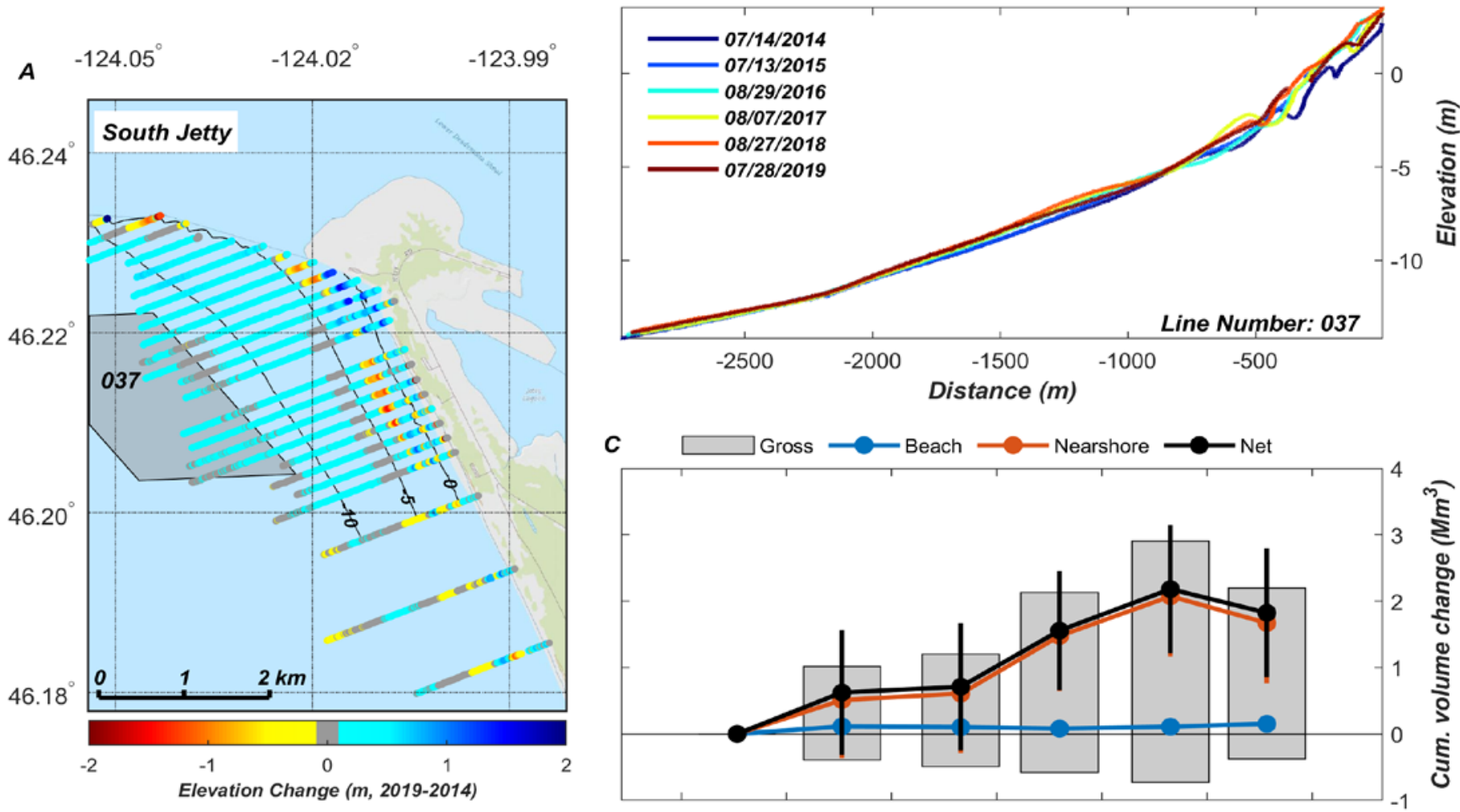

C

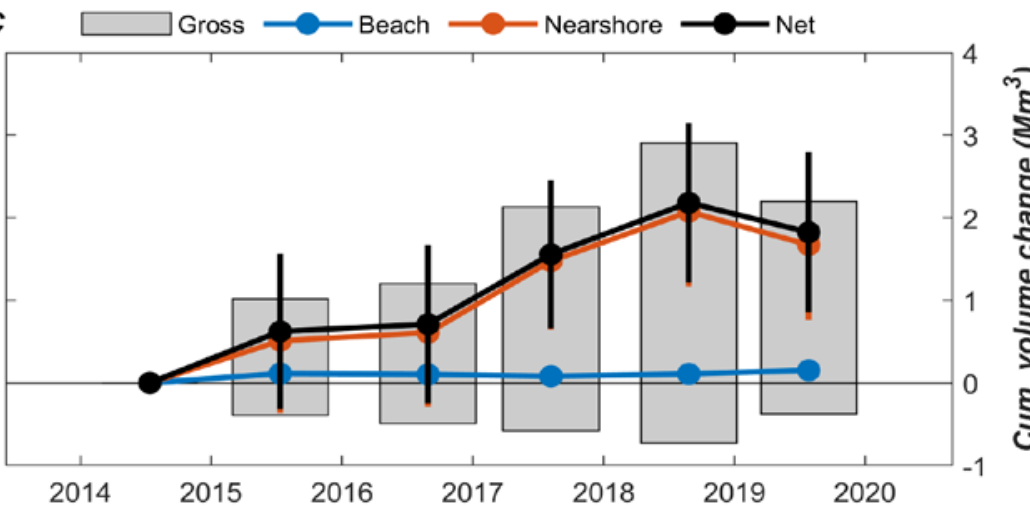

Figure 18. A, Map showing cumulative elevation changes between 2014 and 2019 for South Jetty region within Clatsop Plains subcell (see fig. 17 for location); depth contours (5-m interval between -10 and $0 \mathrm{~m}$ ) based on 2014 survey. Grayfilled box shows nearshore dredge-placement area. $B$, Example profile showing changes in beach and nearshore morphology along survey line 037 (location shown in A). C, Time-series plot of volume changes calculated for South Jetty region; net volume changes are provided for beach and nearshore depth zones, as well as net volume changes integrated over entire region. Abbreviations: km, kilometer(s); m, meter(s); $\mathrm{Mm}^{3}$, million cubic meter(s). 
A

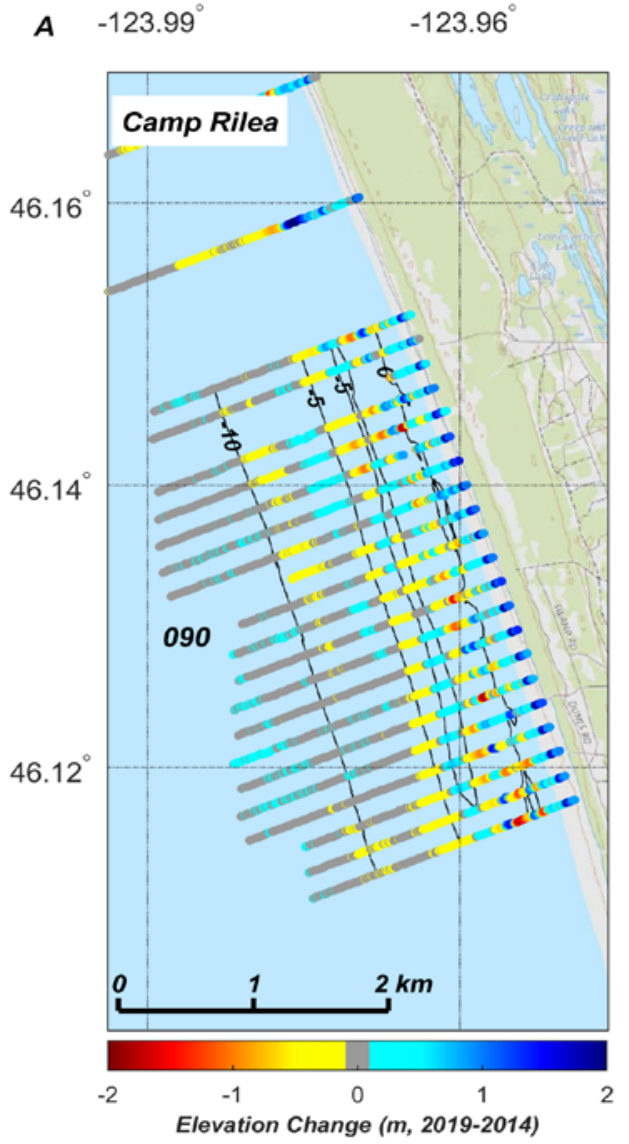

B

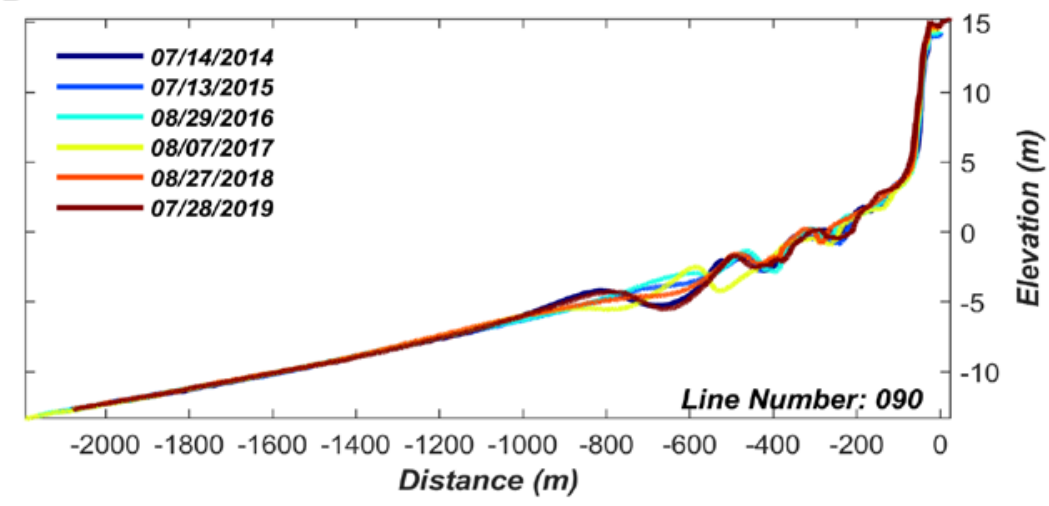

C

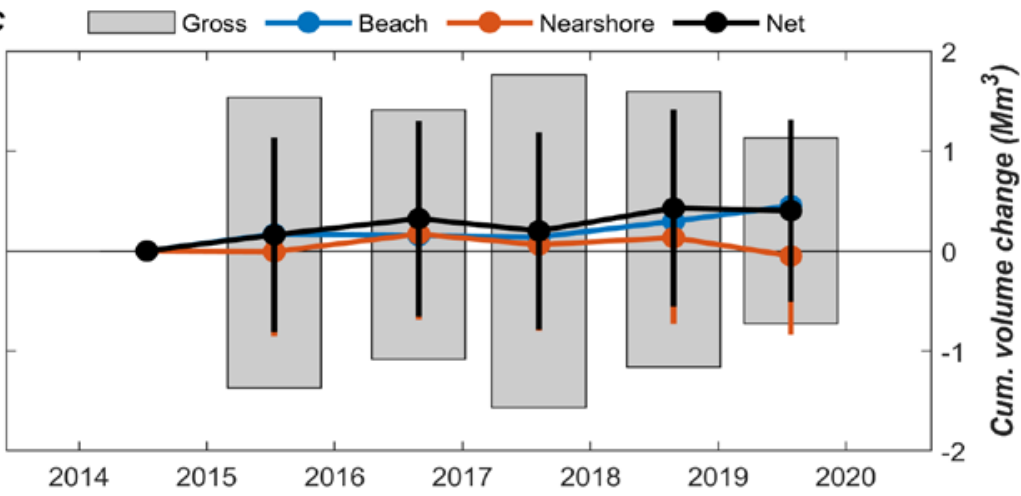

Figure 19. A, Map showing cumulative elevation changes between 2014 and 2019 for Camp Rilea region within Clatsop Plains subcell (see fig. 17 for location); depth contours (5-m interval between -10 and $0 \mathrm{~m}$ ) based on 2014 survey. $B$, Example profile showing changes in beach and nearshore morphology along survey line 090 (location shown in $A$ ). $C$, Time-series plot of volume changes calculated for Camp Rilea region; net volume changes are provided for beach and nearshore depth zones, as well as net volume changes integrated over entire region. Abbreviations: km, kilometer(s); m, meter(s); $\mathrm{Mm}^{3}$, million cubic meter(s).

although the position of the bar was slightly offset between these years. The changes in the positions and morphology of the bars in the Camp Rilea region did not lead to significant net volume change in the nearshore. Net accumulation observed along the beaches was primarily caused by seaward progradation of the dune. The position of the dune crest migrated seaward approximately $10 \mathrm{~m}$ during the study period, and the height of the dune crest increased by more than $1 \mathrm{~m}$.

\section{Integrated Net Volume Change}

Significant net volume change was observed at the regional scale (across several kilometers) for some regions within the CRLC (fig. 20; table 3). The largest regional changes were in the vicinity of the two maintained inlets of Grays Harbor and the mouth of the Columbia River. A total of $2.2 \pm 0.7 \mathrm{Mm}^{3}$ of sediment accumulated within the Westport region on the south side of Grays Harbor inlet between 2014 and $2019\left(440,000 \mathrm{~m}^{3} / \mathrm{yr}\right)$. Similarly, on the south side of the Columbia River inlet, $1.8 \pm 1.0 \mathrm{Mm}^{3}$ of sediment accumulation was observed $\left(360,000 \mathrm{~m}^{3} / \mathrm{yr}\right)$ within the South Jetty region. Erosion was observed on the north side of both of the maintained inlets, although net volume change in Ocean Shores (on the north side of Grays Harbor) was not above the uncertainty threshold $\left(-0.5 \pm 1.0 \mathrm{Mm}^{3}\right)$. Throughout the entire CRLC survey area, the only significant regional erosion pattern was observed at Benson Beach (on the north side of the Columbia River) (fig. 20). A total of $2.1 \pm 0.8 \mathrm{Mm}^{3}$ of sediment eroded from the Benson Beach region between 2014 and 2019 $\left(420,000 \mathrm{~m}^{3} / \mathrm{yr}\right)$. Farther from the inlets, no significant changes in regional sand volume were observed over the study period, although the trends are largely consistent over time. The trends may become significant during future monitoring or if our conservative approach to quantifying uncertainty is refined (for example, distinguishing between systematic and random errors in the datasets). 

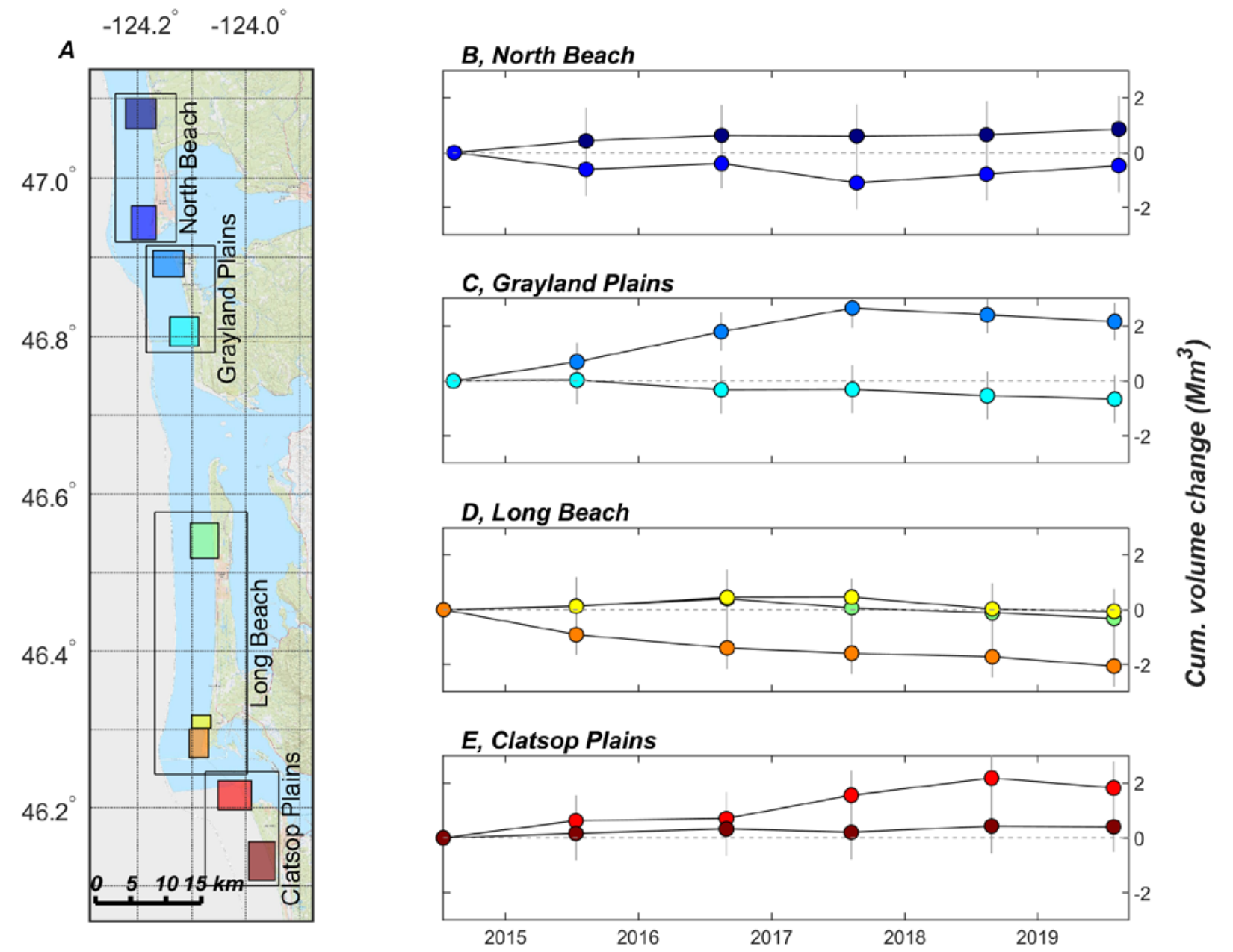

Figure 20. Integrated cumulative net volume changes in 2015, 2016, 2017, 2018, and 2019 for each region having intensive sampling (see table 3 for data). Map $(A)$ shows locations of intensive sampling regions within each subcell. Time-series plots show integrated net volume changes for regions within North Beach $(B)$, Grayland Plains $(C)$, Long Beach $(D)$, and Clatsop Plains $(E)$ subcells. Colors of rectangles in $A$ correspond to colors of dots in plots in $B-E$. Abbreviations: km, kilometer(s); $\mathrm{Mm}^{3}$, million cubic meter(s).

Table 3. Integrated cumulative net volume changes for each intensively sampled region between 2014 and 2019.

[Estimated uncertainty is in integrated net volume change values; yellow cells indicate erosion (that is, volume changes values are greater than uncertainty values); blue cells indicate deposition (that is, volume changes values are less than uncertainty values). Subcells: CP, Clatsop Plains; GP, Grayland Plains; LB, Long Beach; NB, North Beach. Other abbreviations: ha, hectare(s); $\mathrm{Mm}^{3}$, million cubic meters; N, number of profiles within each region. See fig. 20 for locations of each region and plots of values]

\begin{tabular}{|c|c|c|c|c|c|c|c|c|c|}
\hline \multirow{2}{*}{ Subcell } & \multirow{2}{*}{ Region } & \multirow{2}{*}{$\begin{array}{l}\text { Surface area } \\
\text { of region (ha) }\end{array}$} & \multirow{2}{*}{$\mathbf{N}$} & \multirow{2}{*}{$\begin{array}{c}\text { Uncertainty } \\
\left( \pm \mathrm{Mm}^{3}\right)\end{array}$} & \multicolumn{5}{|c|}{ Integrated net volume change $\left(\mathrm{Mm}^{3}\right)$} \\
\hline & & & & & 2015 & 2016 & 2017 & 2018 & 2019 \\
\hline NB & Ocean City & 0.40 & 21 & 1.19 & 0.43 & 0.63 & 0.61 & 0.65 & 0.86 \\
\hline $\mathrm{NB}$ & Ocean Shores & 0.38 & 20 & 0.95 & -0.61 & -0.40 & -1.10 & -0.78 & -0.47 \\
\hline GP & Westport & 0.32 & 17 & 0.69 & 0.69 & 1.80 & 2.66 & 2.41 & 2.16 \\
\hline GP & Grayland & 0.36 & 17 & 0.87 & 0.03 & -0.33 & -0.31 & -0.54 & -0.67 \\
\hline LB & Oysterville & 0.40 & 20 & 1.07 & 0.13 & 0.40 & 0.07 & -0.11 & -0.32 \\
\hline LB & North Head & 0.19 & 11 & 0.37 & 0.12 & 0.45 & 0.46 & 0.03 & -0.06 \\
\hline LB & Benson Beach & 0.37 & 24 & 0.75 & -0.91 & -1.40 & -1.59 & -1.72 & -2.06 \\
\hline $\mathrm{CP}$ & South Jetty & 0.40 & 21 & 0.95 & 0.62 & 0.71 & 1.56 & 2.18 & 1.82 \\
\hline $\mathrm{CP}$ & Camp Rilea & 0.40 & 21 & 0.97 & 0.16 & 0.32 & 0.20 & 0.43 & 0.40 \\
\hline
\end{tabular}




\section{Discussion}

\section{Environmental Forcing}

The Eastern North Pacific Ocean is well known for strong seasonal variations in environmental forcing caused by largescale fluctuations in the positions of high- and low-pressure systems over the Eastern Pacific Ocean and North American continent (Mass, 2008). In the winter, the position of the East Pacific Low shifts to the south, resulting in increased storm frequency and magnitude. Strong southerly winds during winter storms produce large waves and downwelling that is partly responsible for elevating mean water levels along the coast during the winter months (Jay and others, 2015). Rainfall associated with winter storms leads to higher river discharge and increased sediment flux from many smaller streams along the coast, although dams along the Columbia River have dramatically altered its natural hydrologic cycle. These seasonal variations in meteorological and oceanographic processes result in a predictable sediment exchange between the beach and nearshore (for example, Ruggiero and others, 2005). Less well understood are the effects of interannual changes in environmental conditions on beach and nearshore morphodynamics and sediment volume change. In this section, we examine the observed sediment volume change in relation to interannual variations in environmental forcing conditions (for example, fig. 3) to better understand the factors responsible for erosion and deposition along the coast.

The El Niño-Southern Oscillation (ENSO) is a primary factor responsible for large scale, interannual changes in sea-level pressure and atmospheric forcing across the equatorial Pacific. The monitoring period that encompasses this study included the 2015-16 ENSO event, one of the strongest in recorded history (Barnard and others, 2017). During the winter of the 2015-16 ENSO, wave energy was approximately 50 percent greater than average, and mean water levels were elevated by more than $10 \mathrm{~cm}$, resulting in widespread, enhanced seasonal erosion of beaches throughout the Pacific basin, including the CRLC (Barnard and others, 2017). However, our annual observations, which we collect during the summer, did not show that enhanced beach erosion occurred during the 2015-16 ENSO event (fig. 20). Instead, many of the beaches gained volume between the 2015 and 2016 surveys, suggesting that the sediment that eroded from beaches in the winter of 2015-16 during the erosive ENSO conditions remained in the littoral system and that the beaches had recovered before our survey in the summer of 2016. Furthermore, large-scale beach rotations (that is, oscillations in beach volume between the north and south ends of embayed beaches) commonly have been observed elsewhere during strong ENSO events (for example, Ranasinghe and others, 2004). Typical ENSO winters in the Pacific Northwest are characterized by larger, more northward directed waveenergy flux (Barnard and others, 2015) that result in gradients in longshore transport, causing erosion at the south end of the beach and accumulation at the north end (for example, Anderson and others, 2018). However, the 2015-16 ENSO was peculiar in that the direction of wave-energy flux was similar to the 20-yr mean in the Pacific Northwest (Barnard and others, 2017). The lack of a wave direction anomaly is consistent with our observations of beach and nearshore volume change that show no strong evidence for large-scale beach rotation after the 2015-16 ENSO winter.

\section{Sediment Supply}

Interannual variations in the supply of fluvial sediment may be an important factor that contributed to the erosion of Benson Beach, the only region in the study area that had net sediment erosion above the uncertainty threshold (fig. 20). Although the construction of dams on the Columbia River has drastically altered its natural hydrologic cycle and reduced sediment supply to the coast (Sherwood and others, 1990), model simulations presented in Task 2 suggest the system is capable of exporting sand-sized sediment during high discharge conditions. The rate of erosion at Benson Beach was highest between 2014 and 2016, a time period that coincides with drought conditions that affected much of the western United States. Although the drought in the Columbia River drainage basin was not as severe as that in California to the south, anomalously high temperatures throughout the western states led to record low snow pack (Mote and others, 2016), reduced river discharge in the lower Columbia River (fig. 3), and presumably lower sediment flux from the Columbia River to the coast. Owing to its proximity to the Columbia River mouth and connectivity to the fluvial source (see results from Task 2), Benson Beach would likely be most directly impacted by short-term changes in fluvial sediment delivery from the Columbia River.

\section{Dredging}

Although natural variations in wave forcing and fluvial sediment delivery may contribute to the observed net accretion at the south sides of Grays Harbor and the Columbia River, the presence of dredge-placement areas in both of these regions suggests that increasing the sediment supply by placing dredged material in the nearshore is an effective approach for regional sediment management. The effects of dredge placement are particularly apparent in the Westport region where net accumulation was enhanced directly onshore of the dredge-placement site (fig. 11). Both nearshore dredge-placement areas in proximity to the Westport and South Jetty regions are located offshore of our survey lines (with some minor overlap; see figs. 11, 18), suggesting that waves and tides effectively disperse sediment onshore from the placement areas into the nearshore zone (and into our survey area). Repeat surveys performed by the USACE between 2009 and 2017 have suggested that 70 percent of the $2.5 \mathrm{Mm}^{3}$ of sediment placed within the nearshore placement 
site at Westport was dispersed away from the placement area (David Michalsen, 2019, USACE, written commun.), thereby enhancing the coastal sediment budget by as much as 215,000 $\mathrm{m}^{3} / \mathrm{yr}$. Assuming similar volumes of sediment placed during the time period of this study, dredging can account for about 50 percent of the net accumulation $\left(440,000 \mathrm{~m}^{3} / \mathrm{yr}\right)$ that was observed in the Westport region. The connection between the enhanced sediment budget from nearshore dredge placements and the volume changes along intertidal and subaerial elevations is less clear, particularly at Westport where the southern part of the beach has continued to erode (fig. 11). More research is needed to identify the physical processes and time scales associated with transport between nearshore placement sites and adjacent beaches. There may be a lag time of several years between the time of sediment accumulation in the nearshore and that of shoreline progradation, as was observed for the massive increase in sediment supply to the coast following dam removals on the Elwha River (Warrick and others, 2019).

The placement of dredged material likely contributed to the observed net accumulation on the south side of the Columbia River in the South Jetty region $\left(1.8 \pm 1.0 \mathrm{Mm}^{3}\right)$ between 2014 and 2019. Approximately $1.2 \mathrm{Mm}^{3}$ of sediment was placed within the nearby South Jetty Site (SJS) dredgeplacement area over the same time period (USACE, 2019). Note that, owing to the timing between the nearshore surveys and dredge placements, the total volume of dredged material placed within the SJS was calculated using annual totals between 2014 and 2018. Repeat bathymetric surveys of the SJS by the USACE suggest that only a small percentage of the sediment placed within the SJS remained within the site boundaries (13 percent between 2012 and 2018). The sediment placed within the SJS likely was dispersed landward, enhancing the coastal sediment supply. This analysis suggests that about $1 \mathrm{Mm}^{3}$ of the $1.8 \pm 1.0 \mathrm{Mm}^{3}$ observed within the South Jetty region can be directly attributed to the beneficial use of sand dredged from the MCR.

In contrast to the accumulation observed on the south sides of Grays Harbor and Columbia River inlets, severe erosion was observed between 2014 and 2019 at Benson Beach on the north side of the Columbia River (fig. 16). During the same time period, approximately $6.3 \mathrm{Mm}^{3}$ of sediment was placed within nearshore sites on the north side of the Columbia River navigation channel during the monitoring period (USACE, 2019). Most (82 percent) of this sediment was placed within the Shallow Water Site (SWS) to enhance the coastal sediment budget north of the inlet. The SWS is much more dispersive than the SJS, with less than 2 percent of the approximately $33 \mathrm{Mm}^{3}$ of sediment placed within the SWS between 1997 and 2018 being retained (USACE, 2019). Despite the placement of large quantities of dredged material within the SWS and the efficient dispersal away from the placement area, nearby Benson Beach eroded $2.1 \pm 0.8 \mathrm{Mm}^{3}$ between 2014 and 2019. The enhanced sediment supply from dredge placement has not been sufficient to reverse the trend of erosion in that region. Our results suggest that additional nourishment is needed to mitigate the $420,000 \mathrm{~m}^{3} / \mathrm{yr}$ deficit in sediment supply to the Benson Beach region and reverse the steady erosional trend. The persistent erosion - even with enhanced sediment supply — highlights the need for efficient delivery of sediment from the nearshore dredge-placement sites to the eroding beach and nearshore areas. In Task 2 of this study, we present results of a hydrodynamic and sedimenttransport model that was constructed to identify sedimenttransport pathways in the vicinity of the MCR, to identify the most advantageous locations for nearshore nourishment.

\section{Task 2 - Hydrodynamic and Sediment- Transport Modeling}

In this section, we describe the application of a coupled Delft3D-SWAN hydrodynamic, wave, and sediment-transport model (fig. 21) to quantify the sediment linkages between the MCR and adjacent open coasts of the Long Beach peninsula and Clatsop Plains. Hydrodynamic and sedimenttransport modeling at the MCR is challenging owing to the interaction of strong tidal currents and highly variable density stratification, as well as the importance of waves and wavecurrent interaction, of tidal asymmetry and related mean flow in the system, and of wetting and drying of large tidal flats and wetlands in the lower estuary. Previous research has demonstrated that process-based models applied to the Columbia River system are able to accurately simulate important processes such as density stratification (for example,

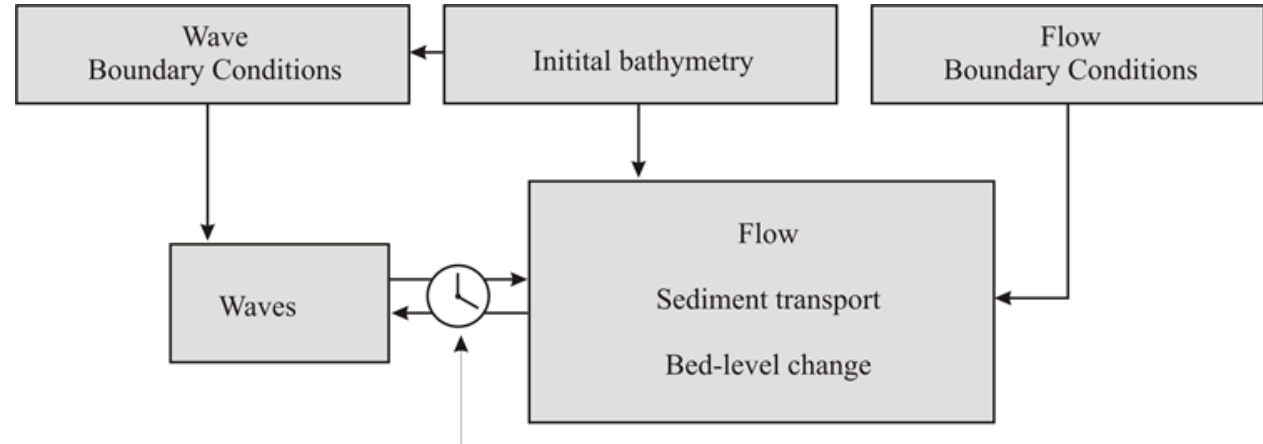

Periodic update wave field
Figure 21. Schematic representation of Delft3D modeling system. 
Karna and others, 2015) and wave-current interaction (Elias and others, 2012; Akan and others, 2017). For this study, the hydrodynamic-model application was adapted from Elias and others (2012). The model grid and boundary conditions were modified and the sediment-transport module was activated to simulate hydrodynamics and sediment transport. Additional analyses were performed on the calculated sediment-transport fields using the Sediment Pathway Interactive visualization Tool (SPIT) developed as part of this study to visualize sediment-transport pathways and to identify the linkages between the MCR, nearshore dredge-placement sites, the North Head study area, and adjacent coastlines.

The next sections describe the implementation of the Delft3D modeling system and SPIT postprocessing analysis. Additional information on the Delft3D modeling system, including testing and validation of the Delft3D Online Morphology system, was reported in Lesser and others (2004). Van Rijn (2007a, b, c) provided explicit descriptions of the sediment transport formulations.

\section{Model Application}

\section{Delft3D Flow}

The hydrodynamic- and sediment-transport-model domain consisted of a structured, orthogonal, curvilinear, 43,356-cell grid that covered the ocean, estuary, and river domain (fig. 22). The ocean domain had a maximum grid-size of $2 \mathrm{~km}^{2}$ along its seaward boundaries. The grid resolution between North Head and the MCR was variable (15 to 100 $\mathrm{m}$ ) in the along-shore direction and $50 \mathrm{~m}$ in the cross-shore direction. Ten equally spaced vertical sigma layers were used to simulate 3D effects within the model domain. The grid was aligned with coastal engineering structures, including the three primary jetties, as well as several training dikes in the vicinity of Baker Bay, Wash. Flow through the structures was limited in the model by using thin dams (no transmission) or dry points. The spatial extent of the grid extends from the MCR roughly 150 and $100 \mathrm{~km}$ to the north and south, respectively.
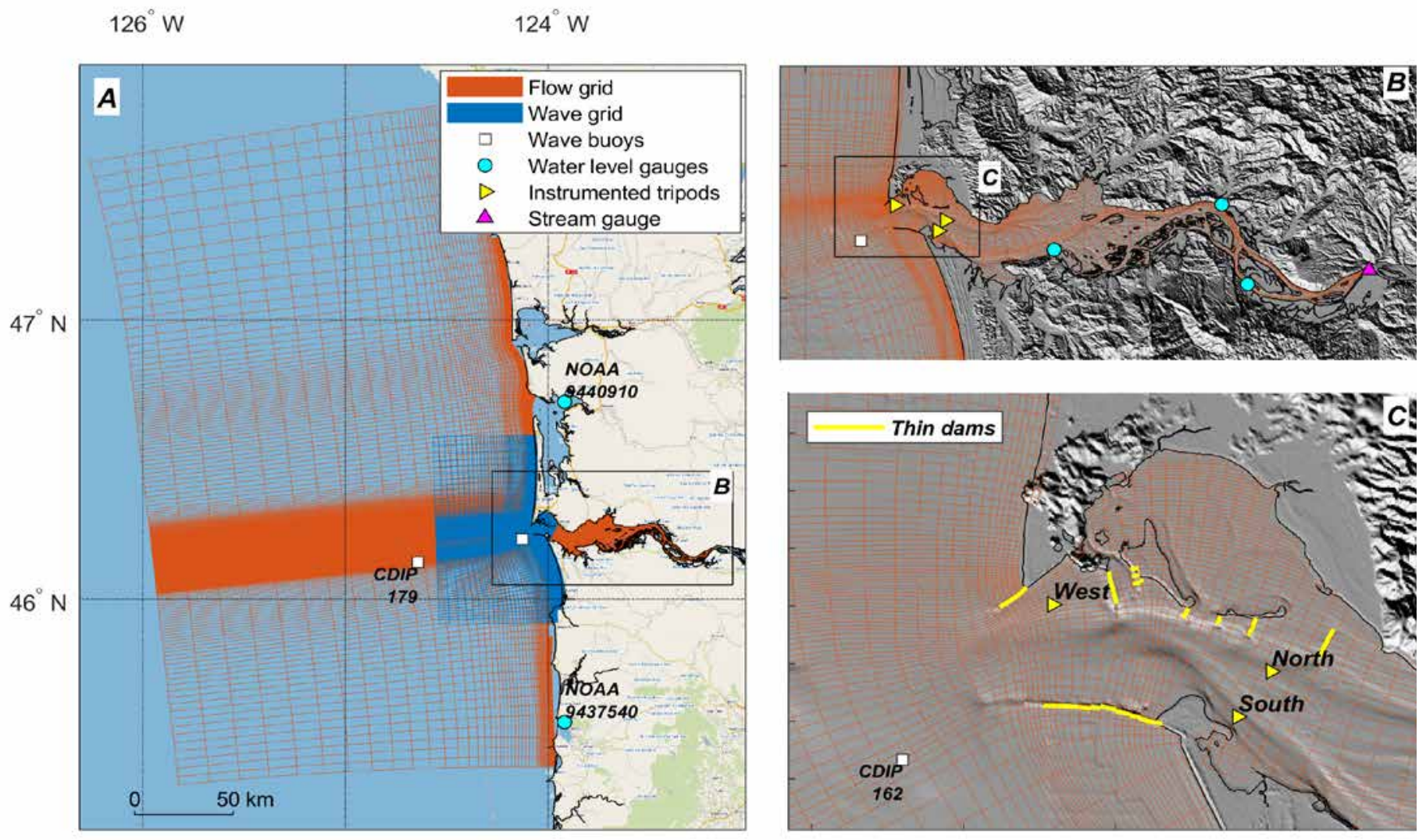

Figure 22. A, Map showing hydrodynamic (red lines) and wave (blue lines) model grids used to simulate sediment transport in Columbia River estuary and at mouth of Columbia River; also shown are detailed hydrodynamic model grids for Columbia River estuary $(B)$, and mouth of Columbia River $(C)$ (grid resolutions in $B$ and $C$ were reduced by factor of three for display). Abbreviations: CDIP, Coastal Data Information Program; km, kilometer(s); NOAA, National Oceanic and Atmospheric Administration. 
This large domain was needed to prevent instabilities at the ocean boundaries during high-discharge conditions. The hydrodynamic and sediment-transport model was run with a computational time step of 6 seconds (s).

The model bathymetry is derived from recent datasets, including the swath bathymetry collected by the U.S. Geological Survey (USGS) in 2013 (Gelfenbaum and others, 2015b). Additional bathymetric data used in the model include swath bathymetry collected by NOAA between 2007 and 2009 (available at https://maps.ngdc.noaa.gov/viewers/bathymetry/) and unpublished single-beam bathymetry collected in 2004 and 2012 by USACE. A previously published digital elevation model of the lower Columbia River (Lower Columbia Estuary Partnership, 2010) was used for the tidal river between the Astoria Bridge and the fluvial boundary. A regional digital terrain model (Love and others, 2012) was used in areas where more recent datasets were not available. The source bathymetric data were converted to a common horizontal datum (NAD83) and to the land-based North American Vertical Datum of 1988 (NAVD88), then it was projected into the Cartesian UTM Zone 10 coordinate system (meters). Deep areas associated with the Astoria submarine canyon were removed from the model bathymetry to improve stability along the oceanic boundaries.

Oceanic boundaries of the MCR model were forced using astronomic tidal constituents derived from the TPXO 7.2 global tide model (Egbert and Erofeeva, 2002). A vertical offset of $1.15 \mathrm{~m}$ (positive values are up) derived from NOAA VDatum (version 3.2; Xu and others, 2010) was applied at the oceanic boundary to account for the difference between local mean sea level and NAVD88. Water levels in the MCR and estuary are influenced by coastal processes such as regional upwelling and downwelling events that induce variations at subtidal frequencies (for example, Jay and others, 2015) and propagate upriver (MacMahan, 2016). Oceanic subtidal variations were imposed at the oceanic open boundary as a time-varying correction to the astronomic tides.

The subtidal time-series was derived from observations of water levels at NOAA stations 9440910 (Toke Point, Wash.) and 9437540 (Garibaldi, Ore.). Water-level timeseries from the two stations were low-pass-filtered using a 66-hour (hr) cutoff to remove fluctuations at tidal frequencies. The low-pass-filtered values from both stations were highly correlated, and an average for the two stations was applied to the oceanic model boundaries. The landward boundary was forced with a time-series of river discharge measured at 30-minute ( $\mathrm{min}$ ) intervals at USGS gauge 14246900 (http:// waterdata.usgs.gov/usa/nwis/uv?site_no=14246900), located at the Beaver Army Terminal near Quincy, Ore. The oceanic and fluvial boundaries were prescribed constant salinity values of 33 and 0 practical salinity units (psu), respectively. The effects of temperature variations on circulation were neglected in the present model application.

Accurate modeling of tidal propagation is essential to simulate water-level dynamics in the MCR and its surroundings. Tidal propagation into inlets such as the Columbia River is modified by bed friction, topographic funneling, and opposing river flow. Whereas river flow and topographic variability are well represented in the model by recent high-resolution inputs, bottom roughness is poorly constrained. Bottom roughness was schematized using the Manning formulation, which relates bed friction to water depth, and it was prescribed during the calibration process (described below). Simulated water levels were compared against time-series measurements of observed water levels during high river-discharge conditions from four locations throughout the study area for the time period between May 10, 2013, and June 16, 2013. The sensitivity of tidal propagation to bottom roughness was examined for a range of spatially uniform Manning roughness coefficients between 0.0202 and 0.0234 in a series of five otherwise identical simulations (fig. 23). We found that a Manning roughness coefficient of 0.0218 best represented mean water levels and variance throughout the domain. The final calibrated model accurately simulated water levels at each of the four observation stations, with a total RMS value less than $12 \mathrm{~cm}$ and an average value of $10 \mathrm{~cm}$ (table 4).

Using the calibrated model, predictions of currents and salinity were compared against time-series measurements at the West Tripod Site as part of the Office of Naval Research (ONR) sponsored Rivers and Inlets (RIVET) II field experiment that was focused on hydrodynamics processes at the MCR. Stevens and others (2017) provided data and associated metadata that describes the collection and processing of timeseries oceanographic data during the experiment. Qualitative comparisons of the current speeds and directions throughout the water column sampled with an Acoustic Doppler Current Profiler (ADCP) show reasonable agreement with the modeled currents at the West Tripod Site during spring tides (fig. 24). Additional comparisons between model predictions and field data were performed near the seabed at the West Tripod Site, where measurements of currents were acquired at $0.6 \mathrm{~m}$ above the bottom using an Acoustic Doppler Velocimeter (ADV) and also measurements of salinity were made at $1.8 \mathrm{~m}$ above the bottom using a Conductivity Temperature Depth (CTD) probe. Peak current speeds near the seafloor of more than 2 $\mathrm{m} / \mathrm{s}$, which were observed during ebb tides, were captured accurately in model simulations. The direction of near-bed currents was generally well represented by the model (fig. 25). A larger discrepancy between model and data was observed during the part of the tidal cycle that corresponds to the daily falling tide (between lower high water and higher low water). During this tidal phase, modeled current speeds are too high; currents are directed offshore for too long, and salinity remains high relative to the observations.

\section{Wave Model}

The spectral wave model SWAN (version 40.72ABCDE) was applied in stationary, third-generation mode to propagate waves from the continental shelf to the coastline. SWAN simulates the evolution of wave action density using the action balance equation (Booij and others, 1999). The wave 

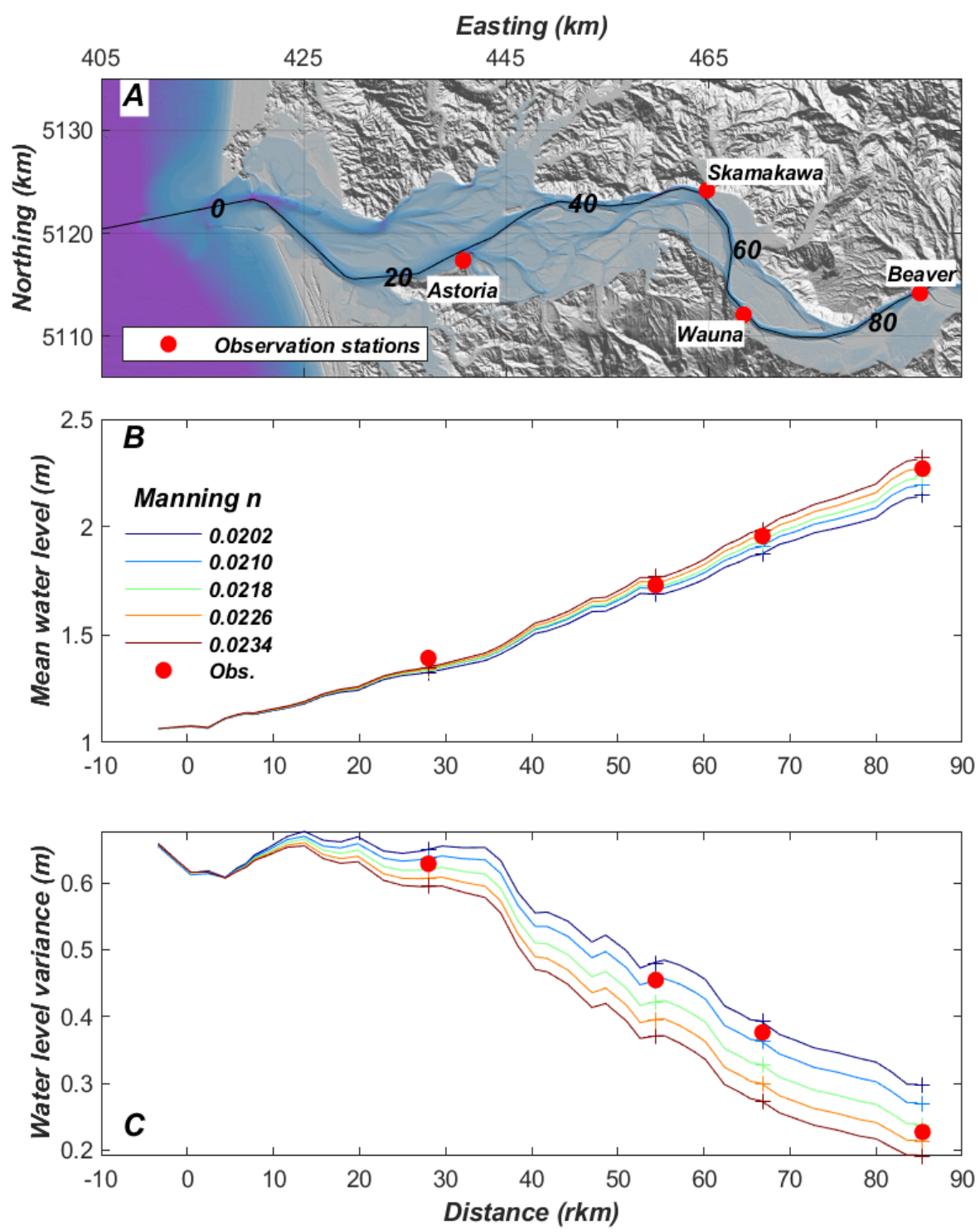

Figure 23. Modeled sensitivity of simulated water levels to variations in bed friction. $A$, Map showing center of main tidal channel (black line) and locations of observation stations (red dots) used for model calibration; black numbers along line correspond to river kilometers ( $\mathrm{rkm}$ ) in $B$ and $C$. $B$, Comparison of modeled and measured mean water levels during 1.5-month simulation for various values of bed friction; colored lines indicate Manning roughness coefficients used in model. $C$, Comparison of modeled and measured water level variance during same 1.5-month simulation as in $B$. Other abbreviations: CDIP, Coastal Data Information Program; km, kilometer(s); m, meter(s); n, coefficient; NOAA, National Oceanic and Atmospheric Administration. model takes into account propagation in geographical space, depth- and current-induced refraction, and shifting of the intrinsic frequency owing to variations in mean current and depth, as well as generation (by wind) and dissipation (by breaking) of waves. Waves were simulated on a grid that covered part of the flow grid (see fig. 22) to improve computational efficiency of the coupled model. The seaward open boundary approximately intersects the location of Coastal Data Information Program (CDIP) buoy 179. The 2D, spatially uniform, time-varying energy spectra derived from measurements at CDIP buoy 179 were used to force the wave model. Interaction between the wave model and flow model in the Delft3D modeling system involves a two-way coupling of a nonstationary hydrodynamic calculation, in combination with regular stationary-wave simulations. SWAN was activated every 30 min during the hydrodynamic simulation, and, using the water levels and depth-averaged currents passed from the flow model, performed a stationary wave simulation.
Wave-parameter settings were based on those reported in Elias and others (2012), who performed extensive calibration of the SWAN wave model in the MCR. The best agreement between modeled and observed wave conditions was found using the default JONSWAP bottom-friction value for swell propagation of $0.038 \mathrm{~m}^{2}$ and dissipation by whitecapping using the Westhuysen (2007) formulation; 37 frequency bins between 0.03 and $1 \mathrm{~Hz}$ were used, along with 72 directional bins that covered $360^{\circ}$. Convergence criteria were set to 99 percent of cells and a maximum of 50 iterations to obtain full convergence for all wave cases.

The influence of different wind-input forcings on modeled wave parameters was assessed as part of the SWAN model calibration. Three wind-input cases were examined, including (1) no wind, (2) time- and space-varying wind, based on the National Centers for Environmental Protection (NCEP) and National Center for Atmospheric Research (NCAR) reanalysis project (NNRP) (Kalnay and others, 
Table 4. Error metrics describing sensitivity of simulated water levels to variations in bed roughness at four observation stations; for each station and model simulation, mean bias, bias-corrected root mean square error, and total root mean square error are provided.

[Definitions of error metrics from Joliff and others (2009). See figure 23 for locations of tide stations. Abbreviations: cm, centimeter(s); RMS, root mean square]

\begin{tabular}{|c|c|c|c|c|c|}
\hline \multirow{2}{*}{ Error metric } & \multirow{2}{*}{$\begin{array}{c}\text { Manning roughness } \\
\text { coefficient }\end{array}$} & \multicolumn{4}{|c|}{ Total error $(\mathrm{cm})$} \\
\hline & & Astoria & Skamakawa & Wauna & Beaver \\
\hline \multirow{5}{*}{ Mean bias } & 0.0202 & 0.07 & 0.04 & 0.08 & 0.12 \\
\hline & 0.0210 & 0.06 & 0.01 & 0.05 & 0.07 \\
\hline & 0.0218 & 0.06 & 0.00 & 0.03 & 0.04 \\
\hline & 0.0226 & 0.05 & -0.02 & 0.00 & -0.01 \\
\hline & 0.0234 & 0.04 & -0.04 & -0.03 & -0.05 \\
\hline \multirow{5}{*}{$\begin{array}{l}\text { Bias-corrected } \\
\text { RMS error }\end{array}$} & 0.0202 & -0.10 & -0.09 & -0.10 & -0.14 \\
\hline & 0.0210 & -0.09 & 0.08 & 0.09 & -0.11 \\
\hline & 0.0218 & 0.09 & 0.09 & 0.11 & -0.09 \\
\hline & 0.0226 & 0.09 & 0.10 & 0.13 & 0.09 \\
\hline & 0.0234 & 0.10 & 0.12 & 0.15 & 0.11 \\
\hline \multirow{5}{*}{ Total RMS error } & 0.0202 & 0.12 & 0.10 & 0.13 & 0.19 \\
\hline & 0.0210 & 0.11 & 0.08 & 0.11 & 0.13 \\
\hline & 0.0218 & 0.11 & 0.09 & 0.11 & 0.10 \\
\hline & 0.0226 & 0.11 & 0.10 & 0.13 & 0.09 \\
\hline & 0.0234 & 0.11 & 0.12 & 0.15 & 0.12 \\
\hline
\end{tabular}
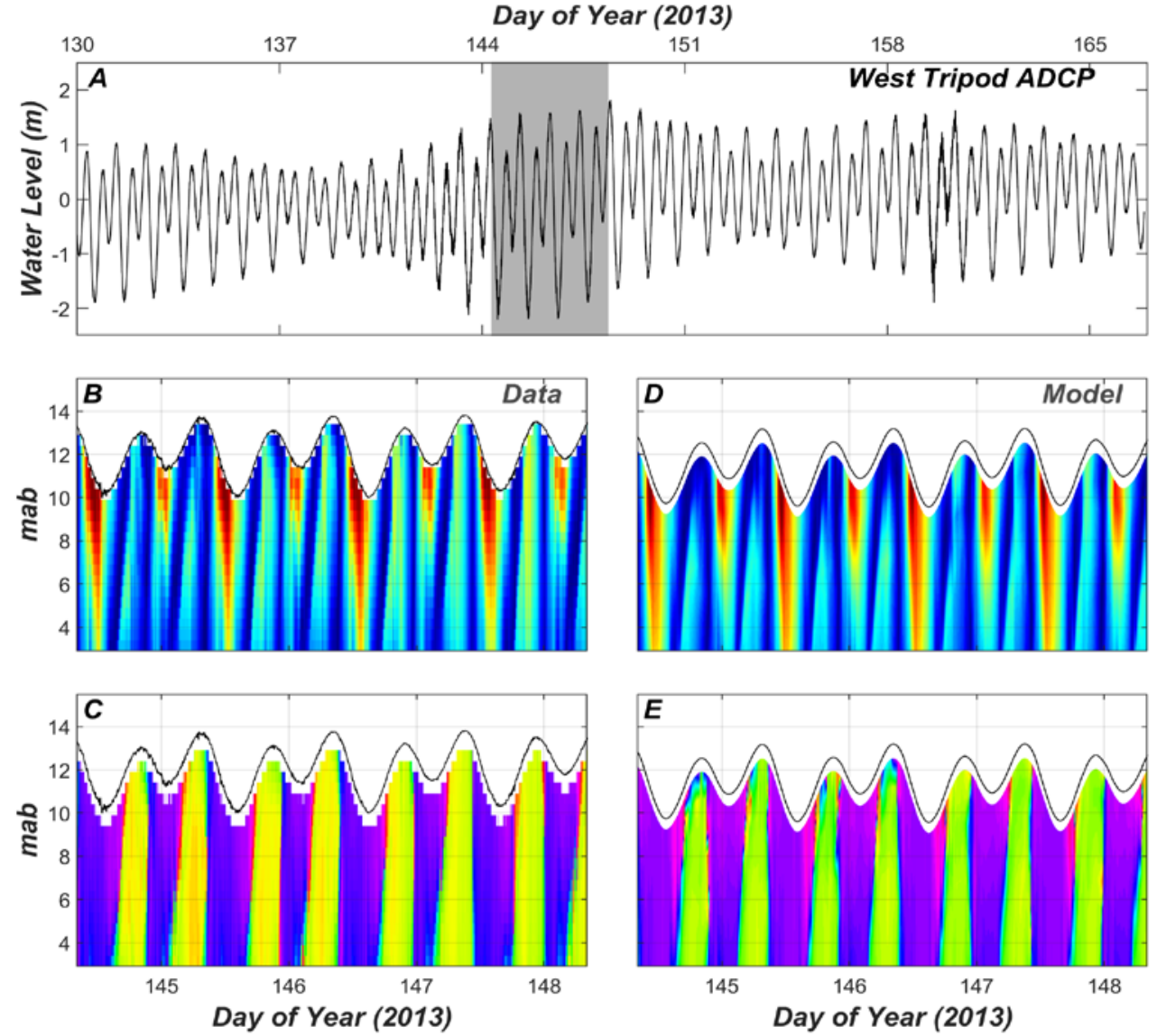

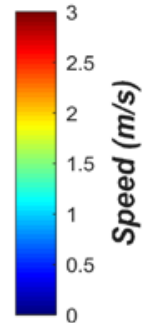

Figure 24. Comparison of measured ("data") and modeled current speeds and directions at West Tripod Site (see fig. 2 for location), in 4-day time period during spring tides. Speeds and directions measured between 2.9 meters above bottom (mab) and water surface, using Acoustic Doppler Current Profiler (ADCP). A, Water levels, as measured throughout entire Rivers and Inlets (RIVET) II field experiment; gray shading corresponds to time period depicted in $B-E$. $B$, Measured current

Direction

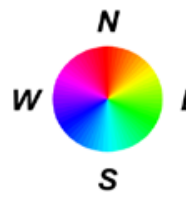

$E$ speeds. $C$, Measured current directions. $D$, Modeled current speeds. E, Modeled current directions. Other abbreviations: $\mathrm{m}$, meter(s); s, second. 

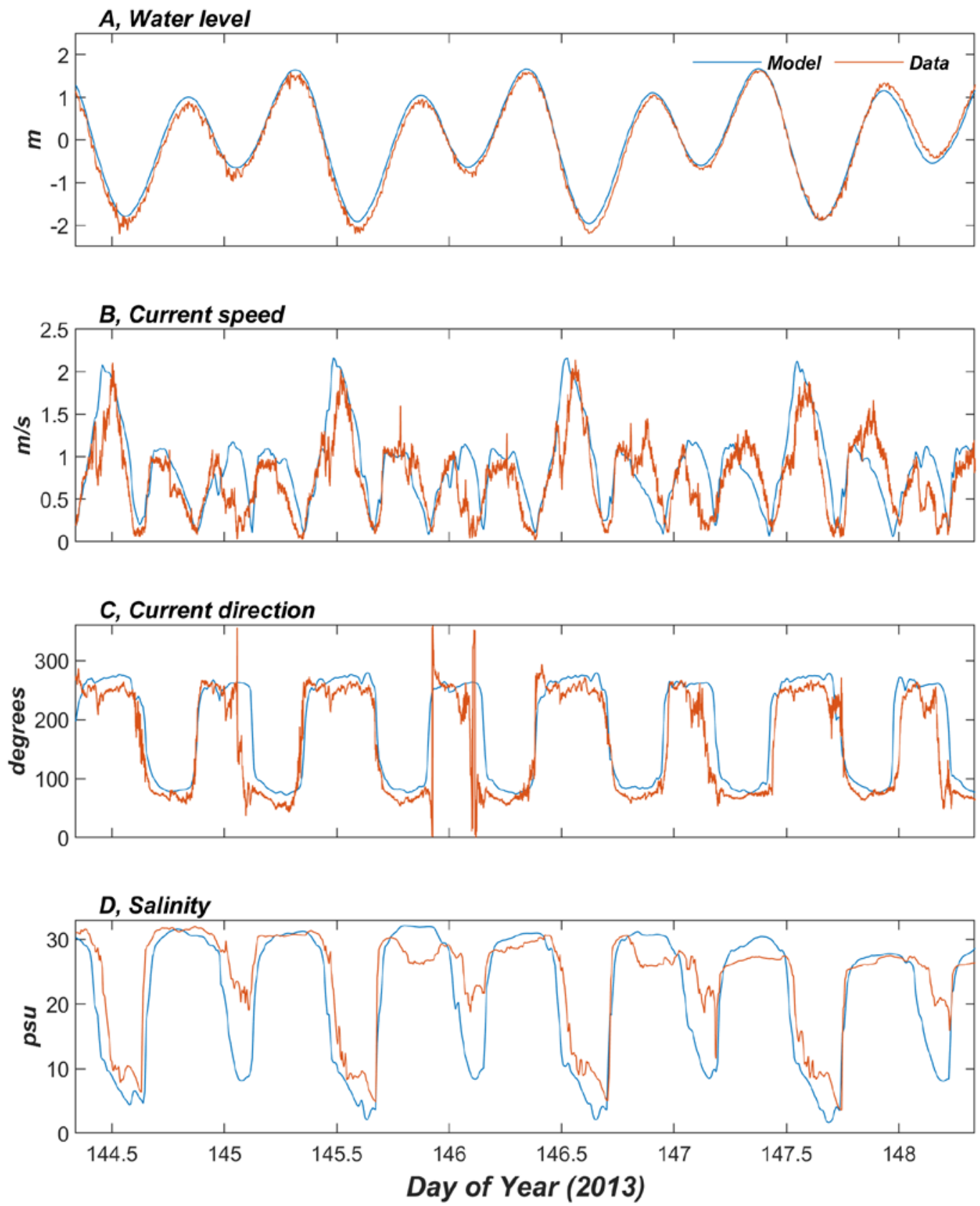

Figure 25. Comparison of modeled and measured ("data") water levels $(A)$, current speeds $(B)$, current directions $(C)$, and salinity $(D)$ near seabed at West Tripod Site (see fig. 2 for location), in same 4-day time period during spring tides as in figure 24. Abbreviations: $\mathrm{m}$, meter(s); psu, practical salinity unit(s); s, second. 
1996) and 12-km spatial resolution, and (3) time-varying but spatially uniform wind derived from measurements at National Data Buoy Center (NDBC) buoy 46029. The time period of October 18 to November 18, 2010, was selected for the sensitivity tests, on the basis of the relatively large wave-forcing conditions and availability of continuous wind data. The NNRP-modeled time-and-space-varying wind fields showed good agreement with wind measurements collected at NDBC buoy 46029 (fig. 26). Bulk wave parameters for three SWAN wind scenarios were compared to wave observations collected at CDIP wave buoy 162, located just offshore, and to the south, of the MCR (fig. 22). The model scenario that used time-and-space-varying wind fields improved the predictions of wave heights, reducing the bias by 20 cm compared to simulation without wind input (fig. 27). Differences in wave heights between the uniform-wind and the time-and-space-varying-wind scenarios were nominal. Other wave parameters (peak period, wave direction) were less sensitive to wind input. All three wind-model setups underestimate the energetic conditions observed on October 25, 2010, when the significant wave height at CDIP wave buoy 162 exceeded $9 \mathrm{~m}$. Additional sensitivity tests to
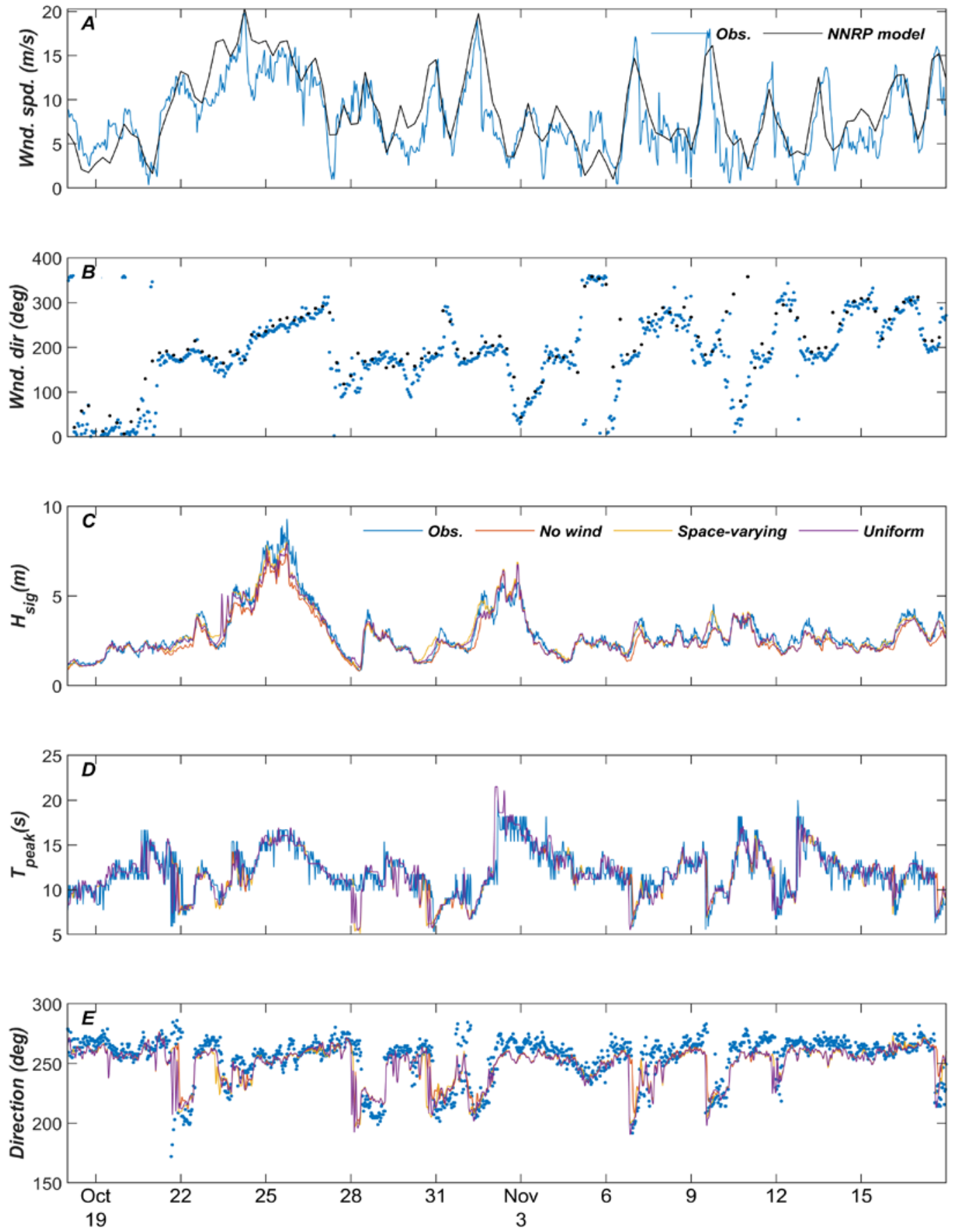

Figure 26. Time-series plots of modeled and measured ("Obs.") wind speed $(A)$, wind direction $(B)$, significant wave height $\left(\mathrm{H}_{\text {sig }}\right)$ $(C)$, peak wave period $\left(\mathrm{T}_{\text {peak }}\right)(D)$, and wave direction $(E)$ between October 18 and November 18, 2010. Model predictions from National Centers for Environmental Protection and National Center for Atmospheric Research reanalysis project (NNRP) shown in $A$ and $B$ were used force wave model for timeand-space-varying wind-input scenario. Comparisons between modeled and measured wave parameters in $C-E$ show three wind-input scenarios: no wind, time-and-space-varying wind ("Space-varying"), and timevarying but spatially uniform wind ("Uniform"). Other abbreviations: deg, degree(s); m, meter(s); s, second(s). 
A
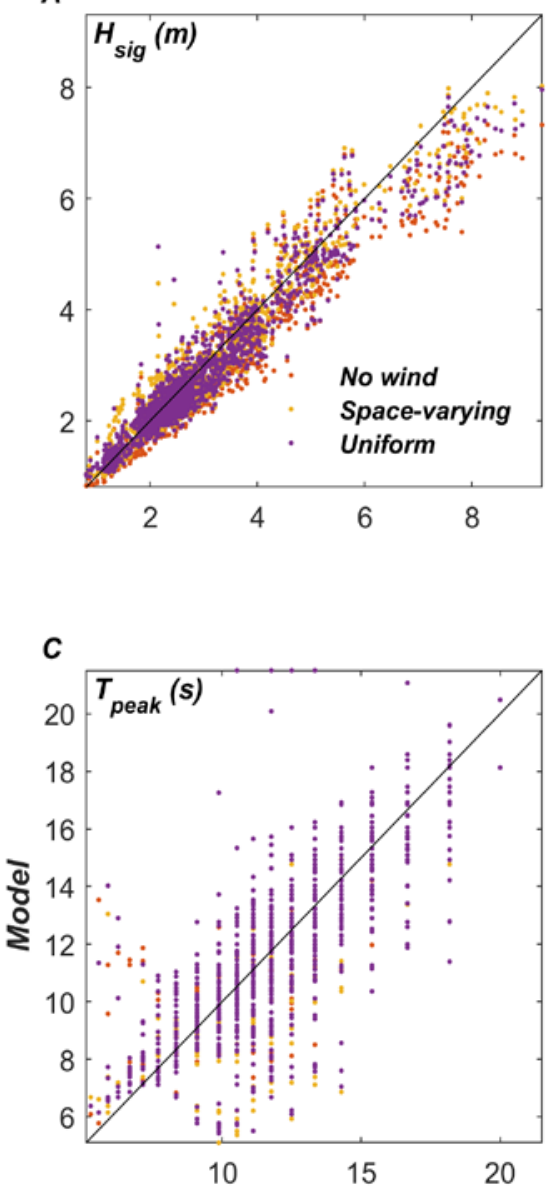

E

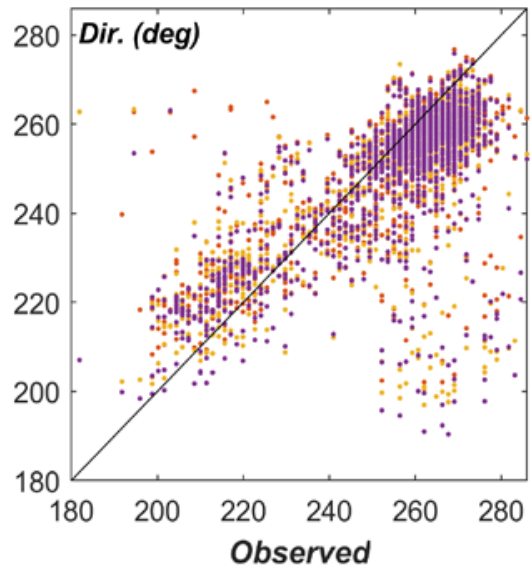

B

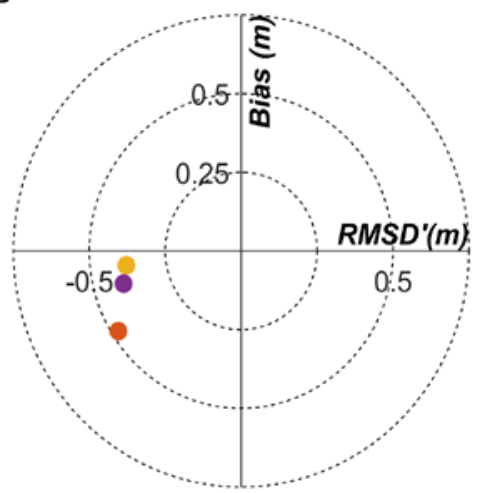

$D$

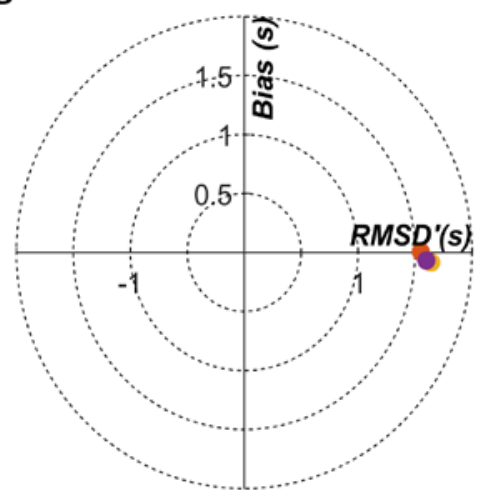

$\boldsymbol{F}$

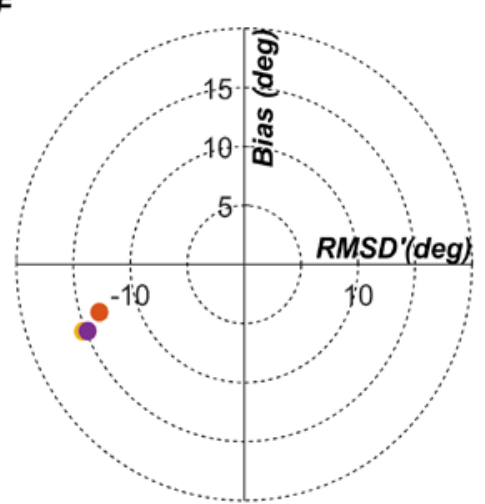

Figure 27. Comparison of modeled and measured wave parameters between October 18 and November 18,2010 . Scatter plots show three wave parameters: $A$, significant wave height $\left(\mathrm{H}_{\text {sig }}\right) ; C$, peak wave period $\left(\mathrm{T}_{\text {peak }}\right) ; E$, wave direction. Modeled wave parameters in scatter plots show three wind-input scenarios: no wind, time-and-space-varying wind ("Space-varying"), and time-varying but spatially uniform wind ("Uniform"). Target diagrams $(B, D, F)$ (for example, Joliff and others, 2009) are provided for each scatter plot. Other abbreviations: deg, degree(s); m, meter(s); RMSD', bias corrected root mean square deviation; s, second(s). 
model input parameters that dissipate wave energy, such as whitecapping, depth-induced breaking, and bottom friction, are needed to resolve the observed underestimation of wave heights during extreme wave events.

\section{Sediment-Transport Model}

The online morphology addition to Delft3D was used to simulate sediment transports in the flow domain at each computational time step (Lesser and others, 2004). The TRANSPOR2004 transport equations, which were used to model the movement of noncohesive sand fractions, are implemented in the Delft3D flow solver. The Delft3D implementation of this formulation follows the principle description of Van Rijn (2007a, b, c), which separates the sediment transport into suspended and bed-load components. Suspended-sediment transport, which is computed by the advection-diffusion equation, includes the effect on fluid density of sediment in suspension. Bed-load transports represent the transport of sand particles in the wave boundary layer in close contact with the bed surface, and they include an estimate of the effect of wave orbital-velocity asymmetry. The bed was schematized as a single sediment fraction, using a median diameter $(\mathrm{d} 50)$ of 200 micrometers $(\mu \mathrm{m})$ with unlimited supply. Holding the bed level constant in the model (to prevent feedback between the flow and changing bed level) was done to isolate the role of the changing flow on the sediment-transport patterns that result from the interaction with the observed morphologic features.

\section{Sediment Pathways Interactive Visualization Tool (SPIT)}

\section{Background}

The Sediment Pathways Interactive visualization Tool (SPIT) was developed to visualize, identify, and analyze the pathways along which sand-sized sediment was transported during the coupled hydrodynamic- and sediment-transportmodel simulations. The SPIT model computes the Lagrangian pathways that idealized particles travel as they pass through a changing vector field. SPIT was adapted from the $\mathrm{mDrift}$ particle-tracking model described in Storlazzi and others (2017) to simulate transport of sediment rather than coral larvae. Existing approaches to sediment-particle tracking (for example, Deltares, 2016) use velocity fields coupled with simple formulas to govern sediment entrainment and settling thresholds that are based on critical shear stresses. This often greatly simplifies the processes of sediment transport, as key behaviors such as particle settling may be neglected.

The main difference between SPIT and existing particletracking methodologies (for example, MacDonald and others, 2006; Soulsby and others, 2011) is that SPIT uses sedimenttransport vector fields derived from a transport formula that has been developed and rigorously tested for noncohesive (sandy) sediment transport (Van Rijn, 2007a, b, c) and computed at each computational time step in Delft3D. Mass fluxes of sediment calculated in a Delft3D simulation were converted to an equivalent volume flux by dividing by the bulk density of the sediment (Equation 1):

$$
S_{v}=\frac{S_{m}}{\rho_{b}}=\frac{\left[\frac{\mathrm{kg}}{\mathrm{m} \cdot \mathrm{s}}\right]}{\left[\frac{\mathrm{kg}}{\mathrm{m}^{3}}\right]}=\left[\frac{\mathrm{m}^{3}}{\mathrm{~m} \cdot \mathrm{s}}\right]=\left[\frac{\mathrm{m}^{2}}{\mathrm{~s}}\right],
$$

where

$$
\begin{array}{ll}
S_{m} & \text { is mass flux; } \\
S_{v} & \text { is volume flux; and } \\
\rho_{b} & \text { is bulk density. }
\end{array}
$$

The resulting flux is equivalent to that of sand volume per unit width of a given grid cell face or transect, passing that point per second (fig. 28). The volumetric flux is converted into an effective velocity for transporting particles by dividing by a length scale (Equation 2):

$$
u_{t r}=\frac{s_{v}}{h_{t r}}=\frac{\left[\frac{m^{2}}{s}\right]}{[m]}=\left[\frac{m}{s}\right],
$$

where

$u_{t r} \quad$ is effective velocity; and

$h_{t r}^{t r}$ is length scale.

For a realistic approximation of particle motion, the length scale should be related to a representative height in the water column over which material is transported and varies depending on the mode of transport. In the case that we are interested in, the maximum potential motion along a pathway for a particle in space, the time scale may be of secondary interest. In that case, for visualization purposes, this length scale factor can be adjusted to increase rate of particle motion because sediment-transport rates often are very small in magnitude. The length-scale factor can only be adjusted until the critical value where particle trajectories begin to diverge with changes in length scale; this critical value can be determined through sensitivity testing.

\section{Application of SPIT to the Mouth of the Columbia River}

To assess the sediment pathways at the MCR, we simulated particle trajectories from 500 initial locations (or sources) throughout the model domain. The initial source locations were determined using k-means cluster analysis (Davis, 2002) that was based on a weighted combination of XY-coordinates and depth below mean sea level. This methodology resulted in a set of sources that was distributed throughout the model domain but provided finer detail in areas that had greater bathymetric complexity (fig. 28). The total number of sources was chosen to deliver sufficient resolution in the areas of interest while also being computationally feasible. 

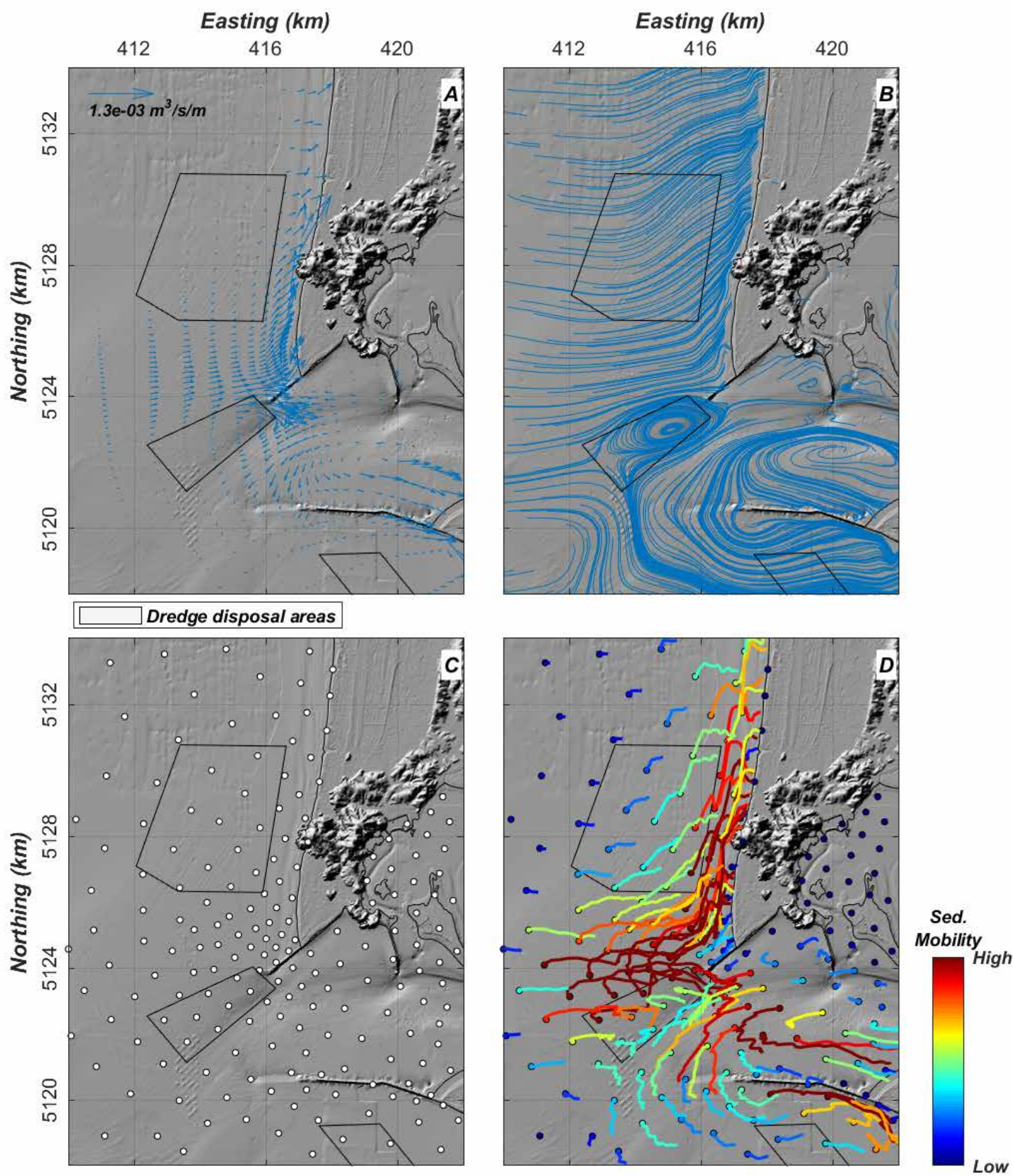

Figure 28. Maps showing Sediment Pathways Interactive visualization Tool (SPIT) visualizations of Lagrangian sediment-transport pathways showing $(A)$ sediment vector fields (blue arrows), $(B)$ streamlines representing vector fields (blue lines), $(C)$ initial positions of sediment sources (white dots), and $(D)$ sediment pathways (colored lines) derived from SPIT analysis. Lengths of vectors in $A$ are scaled to length of blue arrow $\left(1.3 \times 10^{-3}\right.$ $\mathrm{m}^{3} / \mathrm{s} / \mathrm{m}$ ) in upper left corner. Black dots in $D$ indicate initial position (same as white dots in $C$ ) of sediment source; color of sediment pathway indicates relative mobility of source). Here, we define relative mobility as relative distance each source particle travels during simulation. Black boxes show locations of dredge-placement sites. Other abbreviations: $\mathrm{km}$, kilometer(s); m, meter(s); s, second. 
To capture temporal variations in sediment transport (for example, over the course of a tidal cycle), the 10-min mean total (bed load plus suspended load) sediment transport was calculated from the cumulative mean total transport from Delft3D simulations. One particle was released at each source location in the initial timestep. Although particle-tracking models are often highly sensitive to the choice of initial timestep (for example, consider the release of a particle at the ebb versus flood stages of a tidal cycle), the effective particle velocities $\left(u_{t r}\right)$ in this case were sufficiently small such that the precise release time did not affect their ultimate trajectories.

Numerical accuracy was maintained using a 4th-order Runge-Kutta scheme and a computational timestep of $60 \mathrm{~s}$. Particle positions were stored every hour to enable the tracking of particle positions over tidal time scales. A transport height scale $\left(h_{t r}\right)$ value of $0.1 \mathrm{~m}$ was chosen to increase the rate of particle motion in a given timestep. Note that this $h_{t r}$ value basically converts the sediment-transport flux into a velocity that is 10 times the size of the flux. To account for the random motion of particles, a normally distributed perturbation with zero mean and a standard deviation of 0.1 was applied. This corresponds to a random motion equal to 10 percent of the particle's travel distance in a given timestep.

\section{Modeling Approach}

The modeling approach for this study involved two sets of model simulations, performed using the calibrated and validated MCR model (fig. 29). The first simulations (Method 1) were forced with time series of observed waves, wind, and discharge conditions over relatively short timeframes (1-2 months) to characterize detailed hydrodynamics and sediment transport at the event time scale. The results from these simulations provide synoptic, realistic estimates of wave heights, currents, and sediment transports that have high spatial and temporal resolution over the entire inlet domain. Analysis of these data can provide valuable information on governing flow and sediment-transport patterns in the areas that do not contain observation stations. Varying the forcing conditions and analyzing the response of the sediment

\section{Method 1 - Event Time Scales}
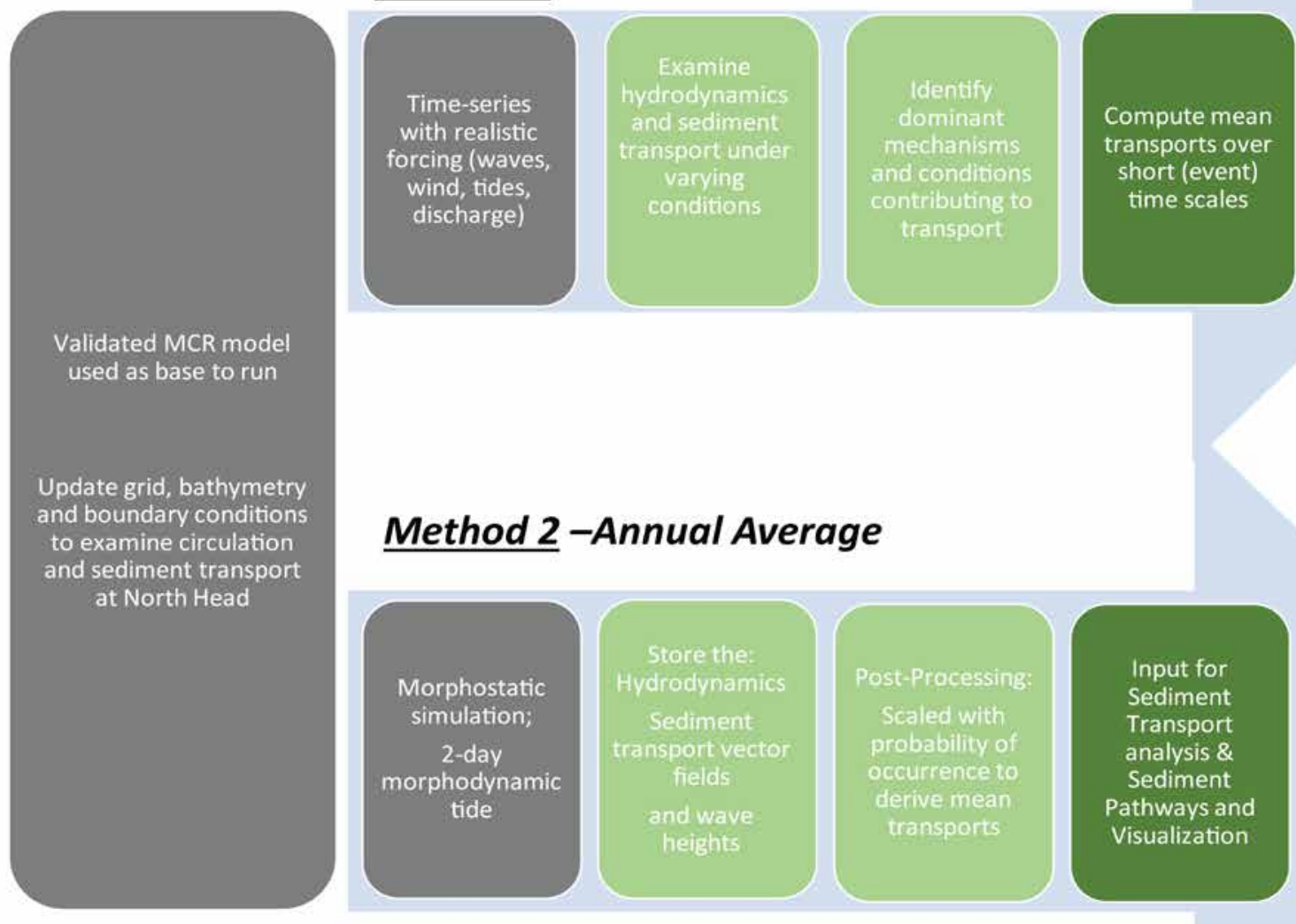

\section{Method 2-Annual Average}

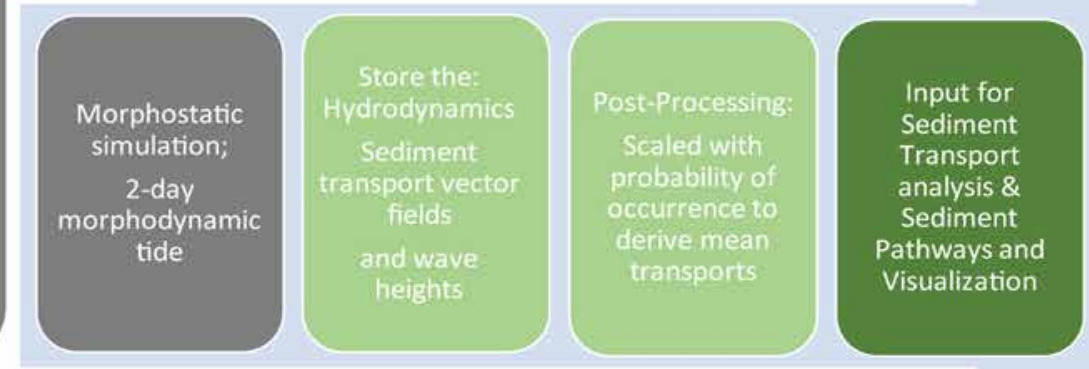

Figure 29. Flow chart showing modeling approaches (Methods 1 and 2) applied during this study (MCR, Columbia River mouth). 
transports in these model simulations allows for identification of the dominant processes responsible for sediment movement (for example, Elias and Gelfenbaum, 2009).

Two time periods were selected to analyze sediment transports using Method 1. The first time period-between October 18 to November 18, 2010 - was selected because it contained relatively large waves that had maximum wave heights of more than $9 \mathrm{~m}$. The second time period-between September 20 and December 1, 2018 — coincided with the pilot placement of dredged material at the North Head study area.

A second set of simulations (Method 2) was constructed to determine the annual exchange of sediment between the MCR, ebb-tidal delta, and adjacent coastal areas. Annually averaged predictions of the sediment budget require simulations that characterize the complete range of forcing conditions to create representative sediment-transport patterns. Such simulations are computationally unfeasible given the spatial extent of the model and the resolution required in the areas of interest. Therefore, input-reduction techniques (for example, Vriend and others, 1993; Lesser, 2009) were used to make such simulations feasible (fig. 29, Method 2).

Morphodynamic schematizations of boundary conditions were derived for wave, tidal, and fluvial forcing to reduce the number of conditions needed to represent annual sedimenttransport patterns and magnitudes. Lesser (2009) provided a comprehensive description of input-schematization techniques for the neighboring Willapa Bay inlet and demonstrated that schematized model inputs can be used for medium-term (3-5 yr) morphodynamic predictions. The wave-climate schematization described in Lesser (2009) was based on a 5-yr timeframe (1998-2003) in which the winter and summer seasons are grouped separately (table 5). A total of 19 wave classes were chosen to represent the morphological impact of all wave conditions that occur during the year. Winter-season waves are grouped into 12 discrete classes of wave heights and directions and their associated probabilities of occurrence; summerseason waves are grouped into seven such classes. Willapa Bay and Columbia River are exposed to a similar wave climate from the northeastern Pacific Ocean; therefore, we utilized the same wave climate schematization as described in Lesser (2009).

The objective of tidal-input schematization using a morphological tide is to replace the complex time-series of tidal water-level and current fluctuations occurring in nature with a simplified tide (or tides) (Lesser, 2009). Gelfenbaum and others (2017) described the construction of morphological tides for the Columbia River. To investigate the influence of

Table 5. Specifications of wave classes used in morphological wave-climate schematizations, subdivided into winter and summer conditions.

[Schematization from Lesser (2009). Abbreviations: deg, degree(s); m, meter(s); s, second(s)]

\begin{tabular}{|c|c|c|c|c|c|c|}
\hline Wave class & $\begin{array}{c}\text { Significant wave } \\
\text { height }(\mathrm{m})\end{array}$ & $\begin{array}{c}\text { Peak wave } \\
\operatorname{period}(\mathbf{s})\end{array}$ & $\begin{array}{c}\text { Wave direction } \\
\text { (deg) }\end{array}$ & Wind speed $(\mathrm{m} / \mathrm{s})$ & $\begin{array}{l}\text { Wind direction } \\
\text { (deg) }\end{array}$ & Probability (\%) \\
\hline \multicolumn{7}{|c|}{ Winter conditions } \\
\hline 1 & 1.00 & 10.2 & 279 & 4.2 & 196 & 5.0 \\
\hline 2 & 2.28 & 8.6 & 216 & 8.2 & 176 & 2.0 \\
\hline 3 & 2.29 & 10.0 & 241 & 6.0 & 176 & 2.0 \\
\hline 4 & 2.16 & 11.4 & 262 & 4.9 & 156 & 4.5 \\
\hline 5 & 2.16 & 13.0 & 278 & 3.6 & 155 & 9.9 \\
\hline 6 & 2.06 & 11.4 & 294 & 2.5 & 195 & 10.4 \\
\hline 7 & 3.88 & 10.1 & 224 & 10.3 & 201 & 3.0 \\
\hline 8 & 3.87 & 12.2 & 257 & 7.5 & 205 & 3.5 \\
\hline 9 & 3.79 & 13.9 & 278 & 5.5 & 199 & 4.5 \\
\hline 10 & 3.71 & 13.4 & 291 & 5.8 & 201 & 2.5 \\
\hline 11 & 5.76 & 12.9 & 241 & 12.0 & 207 & 1.0 \\
\hline 12 & 5.9 & 15.1 & 281 & 8.7 & 216 & 1.0 \\
\hline \multicolumn{7}{|c|}{ Summer conditions } \\
\hline 13 & 0.7 & 9.8 & 271 & 2.94 & 343 & 3.0 \\
\hline 14 & 1.67 & 8.4 & 221 & 5.8 & 198 & 2.5 \\
\hline 15 & 1.58 & 9.9 & 259 & 2.88 & 284 & 6.0 \\
\hline 16 & 1.64 & 10.4 & 281 & 3.66 & 329 & 14.1 \\
\hline 17 & 1.53 & 8.6 & 300 & 5.02 & 334 & 16.6 \\
\hline 18 & 3.5 & 10.7 & 241 & 8.56 & 190 & 3.5 \\
\hline 19 & 3.38 & 13.2 & 284 & 4.06 & 267 & 5.0 \\
\hline
\end{tabular}


river discharge on morphological tide selection, Gelfenbaum and others (2017) selected two time periods representing highand low-discharge conditions when extensive field campaigns were performed. Average discharge during the 2005 USACE Mega-transect experiment (Elias and others, 2012) was $4,000 \mathrm{~m}^{3} / \mathrm{s}$ and, during the 2013 ONR RIVET II experiment (Stevens and others, 2017), was $8,000 \mathrm{~m}^{3} / \mathrm{s}$. For each time period, a Delft3D model simulation forced by tides on the open-ocean boundary, and the measured discharge at the Beaver Army Terminal was performed over an approximately 6-week timeframe. All other parameter settings and boundary conditions between the high- and low-discharge scenarios. The results of a spatially explicit correlation analysis showed that a single representative tide can be selected to accurately model sediment transport over a full spring-neap cycle during both low and high river flow. However, no clear correspondence in the characteristics of the two selected tides (for example, asymmetry, phasing in the spring-neap) was observed. We therefore simulated both the high- and low-discharge scenarios and associated morphological tides identified by Gelfenbaum and others (2017) and investigated the sediment transports and pathways separately.

A total of 38 simulations were performed to calculate the average annual sediment fluxes for high- and low-discharge scenarios. For each discharge scenario (2) and wave class (19) in the wave schematization, a 50-hr simulation was performed. The transports from each wave class were scaled by their probability of occurrence (table 5) and summed to yield the average annual sediment flux. Additional scenarios that have no wave forcing and no salinity variations were also simulated to investigate sediment-transport potential from tides alone and the influence of density stratification on sediment transport. Sediment-transport pathways from each simulation were computed over a time period of 365 days using SPIT and total-transport vector fields saved at 10 -min intervals. Output from the 50-hr Delft3D simulations were looped cyclically over the 365-day duration of the SPIT timeframe.

\section{Results and Discussion}

\section{Method 1-Event Time Scales}

Variations in wave conditions and tidal forcing during the time period of October 18 to November 18, 2010, resulted in complex spatial patterns and magnitudes of sediment transport in the MCR, its ebb-tidal delta, and along its adjacent shorelines (fig. 30). Note that this time period was used to validate the model predictions of wave parameters as shown in figures 26 and 27. Large waves from the west-southwest (fig. 30A) resulted in onshore and northward transport of sand-sized sediment at locations north of the inlet, including the North Head study area. At the same time, strong ebbtidal currents within the inlet, combined with enhanced shear stress from waves, produced a large flux of sediment from the MCR to the ebb-tidal delta. Neap tides and lower wave energy originating from the southwest resulted in northward transport along the beaches north and south of the inlet but little transport within the MCR (fig. 30B). Despite relatively weak tidal forcing, larger waves from the west were capable of causing sediment export from the inlet during ebb tide (fig. 30C). Transport directions reverse from offshore to onshore within the Shallow Water Site dredge-placement area. Waves approaching the inlet from the west refract around the complex bathymetry of the ebb-tidal delta, resulting in northward sediment flux along Benson Beach and the Long Beach peninsula. Smaller waves from the northwest move sediment southward along the beaches, but relatively weak tidal forcing is insufficient to transport much sediment within the inlet (fig. 30D). The results of this simulation suggest that waves are the dominant process at the North Head study area, and they influence sediment transports in the MCR by increasing bed-shear stresses and enhancing sediment export onto the ebb-tidal delta.

Approximately $40,000 \mathrm{~m}^{3}$ of sand dredged from the MCR was placed within the North Head study area during a pilot program between September 19 and 21, 2018 (USACE, 2019). The dredged sand was placed in the southern part of the study area along a northwest-southeast-oriented transect in water depths between about 10 and $15 \mathrm{~m}$ (fig. 31). The linear feature created by the placement was about $75 \mathrm{~m}$ wide and about $60 \mathrm{~cm}$ tall. A simulation was performed to characterize the conditions and evaluate the transport of sand-sized sediment for 72 days after the pilot placement. Transport fluxes during this time period were generally low relative to the highly energetic conditions examined in 2010. The model simulation suggests that tidal currents alone were not capable of resuspending and transporting sand-sized sediment placed during the pilot program. Offshore wave heights did not exceed $4 \mathrm{~m}$ for more than a month after the pilot placement, and little sediment mobility and transport occurred during this time (fig. 32) relative to the 2010 time period. Wave energy increased in late October 2018, enhancing bed-shear stresses and causing sediment to be mobilized throughout the pilot-placement area, according to the model simulations. Additional wave events in November 2018 resuspended sediment at both the shallower (southeastern) and deeper (northwestern) extents (fig. 32) of the pilot-placement transect. During these transport events, sediment fluxes were 3 to 10 times higher at the shallower (southeastern) end of the pilot placement compared to the deeper (northwestern) end.

\section{Method 2-Schematized Simulations}

In this section, we present an analysis of the governing processes that dominate the patterns and relative magnitudes of sediment transport during an average year at the lower parts of the CRE and MCR, as well as their adjacent shorelines. This analysis is based on the schematized model simulations for years that had low (2005) and high (2013) river discharge. In addition to the simulations that use full forcing conditions 


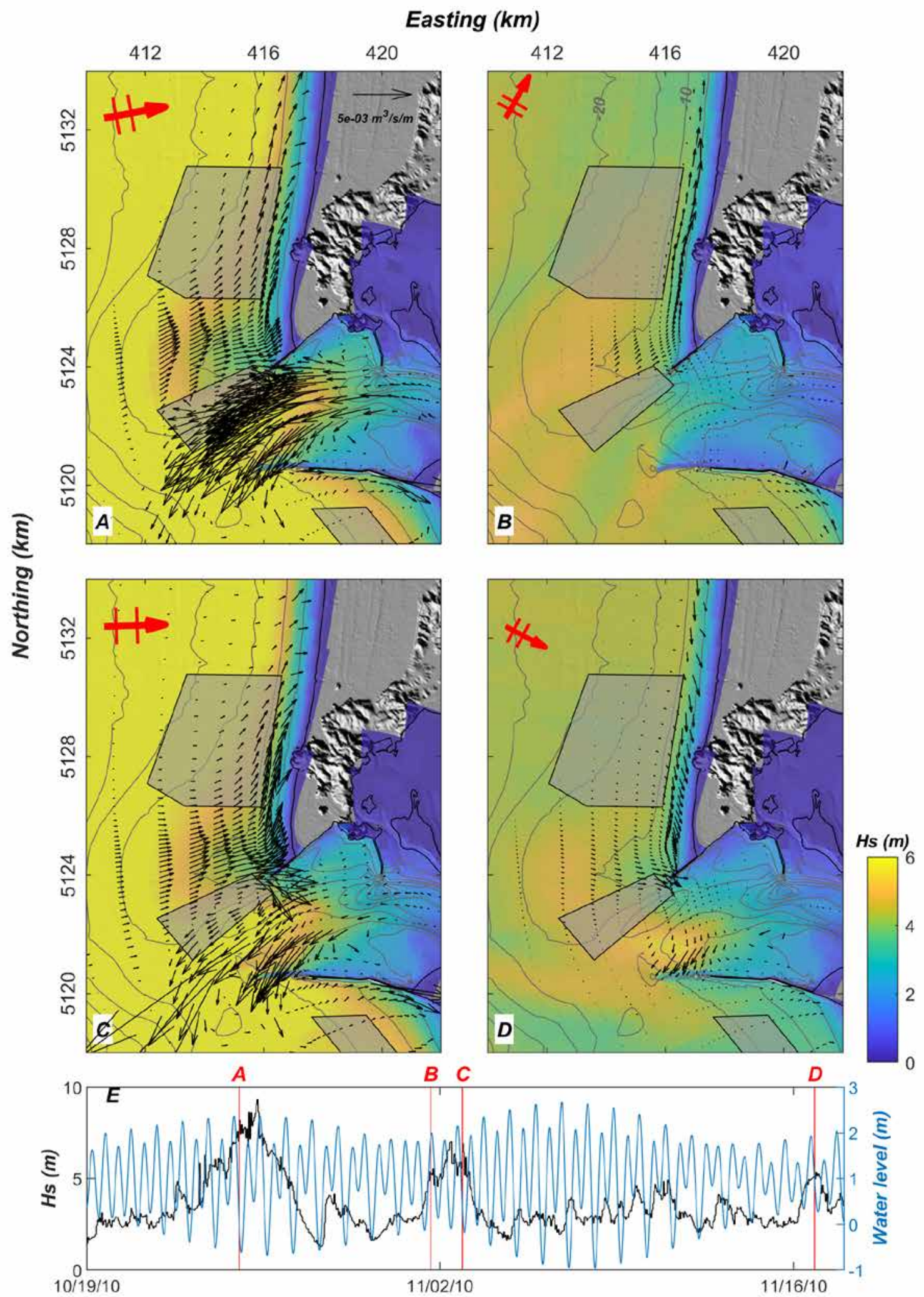

Figure 30. Sediment-transport dynamics under varying wave- and tide-forcing conditions. $A-D$, Maps showing modeled wave heights $(\mathrm{Hs})$ and sediment-transport vectors (black arrows) at selected times (see $E$ ) between October 18 and November 18, 2010. Red arrows in upper left corner denote incident wave direction at offshore location. Lengths of vectors are scaled to length $\left(5 \times 10^{-3} \mathrm{~m}^{3} / \mathrm{s} / \mathrm{m}\right)$ of black arrow in upper right corner of $A$. Gray-filled boxes show locations of dredge-placement sites. $E$, Time-series plot of significant wave heights (black lines) and water levels (blue lines) throughout model simulation; red lines show times of maps in $A-D$. Other abbreviations: km, kilometer(s); m, meter(s); s, second. 


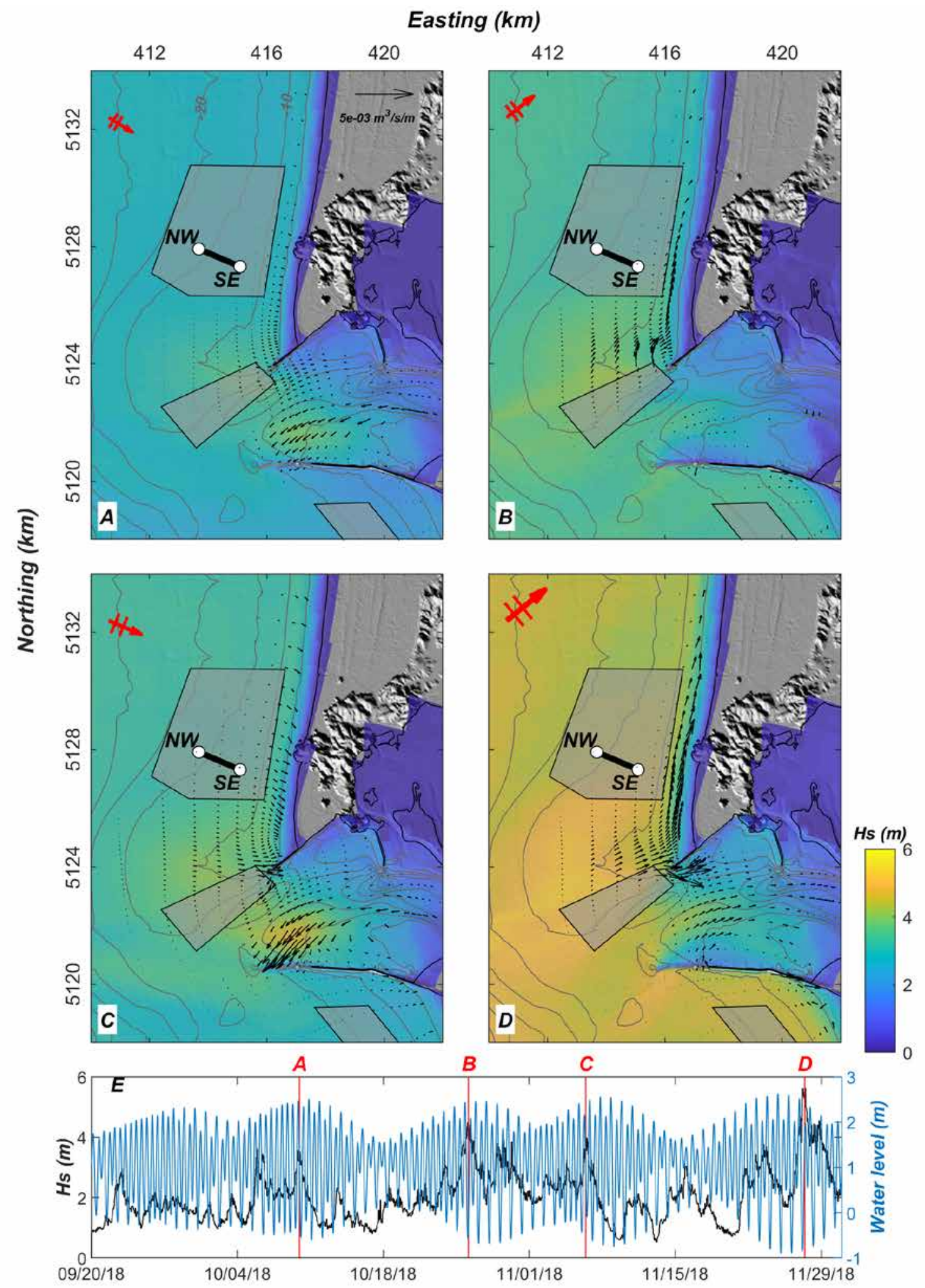

Figure 31. Sediment-transport dynamics under varying wave- and tide-forcing conditions after pilot placement of dredged material within North Head study area. $A-D$, Maps showing modeled wave heights (Hs) and sediment-transport vectors (black arrows) at selected times (see $E$ ) between September 20 and December 1, 2018. Thick black line shows approximate location of pilot placement; white dots mark deeper (northwest [NW]) and shallower (southeast [SE]) ends. Red arrows in upper left corner denote incident wave direction at offshore location. Lengths of vectors are scaled to length $\left(5 \times 10^{-3} \mathrm{~m}^{3} / \mathrm{s} / \mathrm{m}\right)$ of black arrow in upper right corner of $A$. Gray-filled boxes show locations of dredge-placement sites. $E$, Time-series plot of significant wave heights (black lines) and water levels (blue lines) throughout model simulation; red lines show times of maps in $A-D$. Other abbreviations: km, kilometer(s); m, meter(s); s, second. 

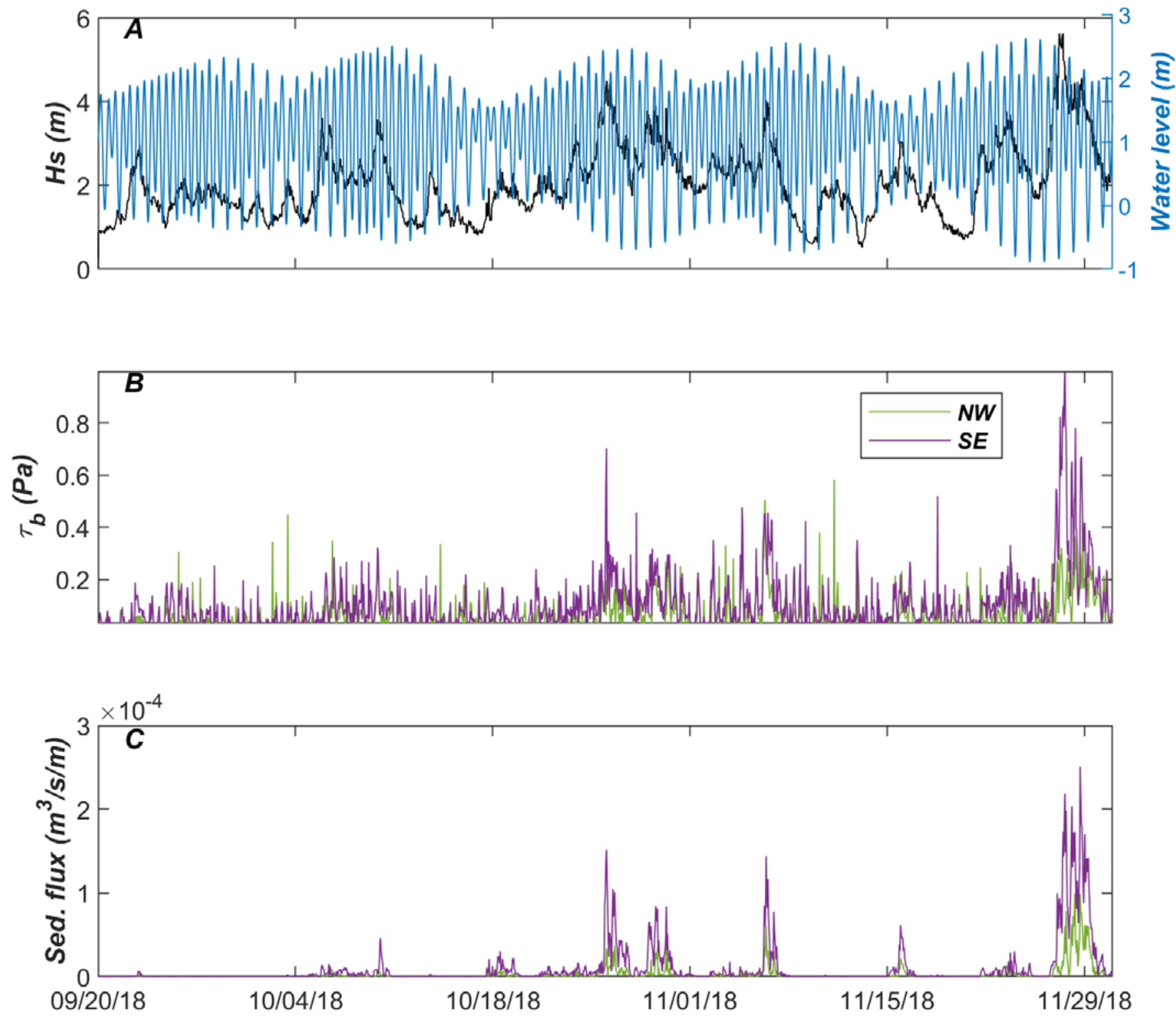

Figure 32. Time-series plots of $(A)$ water levels (blue lines) and significant wave heights (Hs; black lines), $(B)$ bed-shear stress $\left(\tau_{b}\right)$, and $(C)$ sediment-transport flux for 72 days (between September 20 and December 1, 2018) after pilot placement of dredged material within North Head study area. Time-series plot in $A$ depicts same offshore location and conditions as in figure 31 (see fig. 31E); time-series plots in $B$ and $C$ show model output at same two locations (shallower northwest [NW] and deeper southeast [SE] ends of pilot placement) shown in figs. 31A-D. 0ther abbreviations: $\mathrm{m}$, meter(s); $\mathrm{Pa}$, pascal(s); s, second. 
(for example, tides, waves, river discharge), simulations also were performed with no waves and with no fresh-water discharge. These simulations allowed us to understand how the different forcing mechanisms (waves, tides, river flow, and baroclinic circulation) affect sediment transport at the study site. However, we caution that the calculated magnitudes of sediment transport presented in this analysis cannot be directly related to observed erosion and deposition volumes, owing to the assumptions used in the modeling (for example, single grain size, unlimited sand supply, no morphodynamic feedback). The results from selected simulations are described below; in addition, maps showing wave heights, mean total-sediment-transport values, and visualizations of sediment-transport pathways for all simulations are provided in appendix B.

\section{Low-River-Discharge Conditions}

Figure 33 summarizes the sediment-transport fluxes averaged over a year during low-flow conditions for simulations forced with tides alone (left panels [figs. 33A, $C]$ ) and including wave forcing (right panels [figs. 33B, $D]$ ). The year-averaged transport rates are calculated from the 19 individual wave simulations and are scaled with their probabilities of occurrence (see table 5). Tides only introduce a small $\left(1,960 \mathrm{~m}^{3} /\right.$ tide $)$ net sediment export from the Columbia River to the Pacific Ocean. Transport rates decrease in the MCR (between the jetties), suggesting that transports from tide-averaged circulation contribute to sediment accumulation in this area. The patterns of tide-averaged circulation are related, in part, to the effect of density stratification, as well as to the presence of the deep channel at the MCR. The model predictions of sediment accumulation in the MCR are consistent with the extensive dredging efforts that are needed to maintain the navigation channel. Net sediment-transport rates from tides alone are negligible outside of the inlet, north and south of the jetties. Tidal transports alone are, therefore, unlikely to transport sand-sized sediment in the North Head study area.

Sediment-transport rates at the MCR and along its adjacent coastlines increased when wave forcing was imposed during the model simulations (figs. $33 B, D$ ). Although the sediment export from the estuary remained unchanged $\left(2,500 \mathrm{~m}^{3} /\right.$ tide $)$, the inclusion of waves induced a reversal (relative to the tide-only scenario) in the sediment exchange at the MCR $\left(3,730 \mathrm{~m}^{3} /\right.$ tide $)$. The reversal can likely be explained by waves breaking on the ebb-tidal delta. Waves enhanced shear stresses and sediment resuspension, increasing the amount of sediment that is available for advection by tidal currents. This process is more important on the shallow ebb-tidal delta, where flood currents dominate and transport is directed towards the MCR. Wave-enhanced resuspension is limited in the deeper areas inside the MCR, where ebb currents are dominant. This introduces a larger asymmetry in ebb- and flood-tidal transports, changing the near-balanced transports to landward-directed transports. Convergence of the transports landward of the deepest part of the navigation channel indicates that waves enhance sediment accumulation in this part of the channel.

Over an average year of wave conditions, littoral processes in surf zones along the shorelines adjacent to the MCR disperse sediment northward and southward, away from the inlet (figs. 33B, D). On the north side of the inlet, model simulations indicate net northward-directed alongshore transport. The magnitude of the northward transport increases between the North Jetty and North Head, whereas farther north, the magnitude of net along-shore transports decreases, and it is negligible along this part of the Long Beach peninsula. South of the inlet, net along-shore transport is relatively weak and is directed southward. The gradients in along-shore transport are related to wave-sheltering and wave-refraction by the ebb-tidal delta and by the North and South Jetties. As a result of the convergences and divergences in along-shore transports, a large net northward-directed sediment flux along Benson Beach is predicted that exceeds the net landward-directed transports. This observation is consistent with the observed erosion of Benson Beach. Conversely, the model predicts a convergence of sediment transport and accumulation north of North Head. The model does not predict strong gradients in along-shore transport south of the inlet over an average year.

\section{High-River-Discharge Conditions}

Overall, the tide- and annual wave-averaged transport patterns during high-discharge conditions (fig. 34) are similar to the low-flow conditions described above. Net sediment delivery to the MCR from the estuary increases during highflow conditions (figs. $34 A, C$ ). In both the high- and low-flow cases, residual tide-averaged transport exports sediment from the mouth of the river to the ebb-tidal delta offshore. However, during low-flow conditions, most of this material deposits in front of the MCR, whereas, during high-flow conditions, approximately 20 percent of the sediment bypasses the river mouth towards the north. During high-flow conditions, transports to the north of the jetties are still small, but these transports are larger compared to those during the low-flow conditions. High river discharge alters estuarine circulation and residual tidal currents, resulting in a seaward shift in the area where sediment accumulation is predicted. During high river discharge, we can still observe a decrease in transport rates towards Jetty A, but a reversal in transport direction seaward of Jetty A does not occur. Wave-driven littoraltransport patterns outside the inlet are largely unchanged between high- and low-flow conditions.

On the ebb-tidal delta (represented by the transect adjacent to the North Jetty), a relatively large $\left(3,160 \mathrm{~m}^{3} /\right.$ tide $)$ net landward-directed sediment transport occurs, which indicates an active sediment transport from the ebb-tidal delta towards Benson Beach. At this location, large waves dissipate on the shallow ebb-tidal delta, enhancihng bed-shear stresses and generating wave-driven currents that transport sediment 
landward. Transport rates here exceed the landward transport rates that occur to the north. At the North Head study area, landward transport rates are about 80 percent smaller.

\section{Analysis of Sediment Pathways}

Sediment-transport vectors provide valuable information on the processes that contribute to sediment dynamics and the relative magnitudes of potential transport of sand-sized sediment at the MCR. Through the analysis of the sedimenttransport pathways described below, we aim to understand the connectivity and linkages between the lower estuary, ebb-tidal delta, and shorelines adjacent to the MCR under variable wave, tide, and discharge conditions. As noted above (see Methods section), sediment-transport pathways were identified with SPIT to provide a Lagrangian visualization of the transportvector fields. Note that the computations performed with SPIT are not tracer simulations, as the rate of sediment movement is not calibrated to represent the actual particle velocity. The length of the pathway can, therefore, only be used qualitatively, and it must be interpreted as relative sediment mobility between source locations. Longer pathways indicate higher sediment mobility compared to shorter pathways.

The sediment pathways for the 19 individual wave conditions were calculated similarly for both high- and lowriver-discharge conditions, and examples of such sedimenttransport pathways for four wave conditions are shown in figures 35 and 36, respectively. During low-wave conditions, the dominant sediment movement occurred in the estuary and mouth (fig. 35A), and sediment pathways were predominantly directed offshore through the navigation channel and MCR. Some pathways along the northern part of the channel indicated landward transport during low-discharge conditions. Sediment mobility in the estuary increased during high-flow conditions, and all transport pathways directed offshore (fig. 36A).

Enhanced shear stress owing to waves generally increased the length of the pathways observed along the coasts under both high- and low-discharge scenarios. For moderate wave energy directed from the southwest and a significant wave height of $3.5 \mathrm{~m}$ and peak period of $10.7 \mathrm{~s}$, northwarddirected pathways were observed along narrow surf zones both north and south of the inlet (figs. 35B, 36B). The relative mobility of sediment transported in the surf zone was much higher for sources on the north side of the inlet relative to that of the south. In addition, sediment sources originating within the MCR and ebb-tidal delta on the north side of the navigation channel, including several originating within the Shallow Water Site dredge-placement area, were directed to the north and ultimately were incorporated into the surf-zone pathways, suggesting that a direct connection between MCR sediment and beaches to the north exists under these wave conditions. On the other hand, sediment-transport pathways that originate from sources to the south of the navigation channel within the MCR either terminated along the South Jetty or were directed onshore towards Clatsop Spit, suggesting that no connection exists between the MCR and adjacent beaches to the south under these conditions.

Southward-directed littoral transport was observed for wave energy from the northwest, a wave height of $3.71 \mathrm{~m}$, and a peak wave period of $13.4 \mathrm{~s}$ (figs. $35 C, 36 C$ ). Under low-discharge conditions, sediment-transport pathways from sources that originate in shallow areas north of the inlet, including the North Head study area, were directed onshore and incorporated into the surf zone. However, higher discharge conditions resulted in more complicated pathways north of the inlet, and some pathways originating within the North Head study area were directed offshore. The North Jetty clearly separates the inlet from shallow sources to the north by interrupting southward-directed littoral-transport pathways, under both high- and low-discharge conditions. Although most pathways that originate from within the inlet were directed offshore and terminated on the ebb-tidal-delta front, the moderate northwestward-directed wave energy resulted in some connectivity between the MCR and adjacent beaches. For instance, sediment-transport pathways that originate from sources within the MCR on the south side of the navigation channel were directed offshore and southward and were incorporated into the littoral transport along Clatsop Plains beaches.

Large waves from the southwest resulted in high sediment mobility and northward-directed transport pathways along a large part of the ebb-tidal delta, including the North Head study area and Shallow Water Site dredge-placement areas (figs. 35D, 36D). Surprisingly, dispersal pathways in both northward and southward directions were enhanced with high wave energy from the southwest. Whereas the sources that originate on the north side of the inlet followed the dominant wave direction, pathways that originate within the inlet and on the south side of the ebb-tidal delta took a circuitous route, and they were somewhat sensitive to discharge conditions along paths that ultimately were mostly directed to the south. Although the sediment mobility was relatively low, offshore-directed pathways were observed for sources that had relatively deep initial locations.

A total of 19,000 source pathways were computed with SPIT, using 19 wave classes, two discharge scenarios, and 500 sediment sources per simulation. Interpretation and synthesis of the raw results were challenging owing to the density of the sediment-transport pathways and the number of scenarios examined (fig. 37A). Results were simplified by examining sediment-source regions within several polygons of interest, including the North Head study area, Benson Beach, and the maintained navigational channel. The pathways for high- and low-discharge scenarios were generally similar, and so only the results from the low-discharge scenarios are described here. Sediment-transport pathways from sources that originate from within the North Head study area were directed onshore and northward for wave classes from western and southwestern directions (fig. 37B). Waves from the northwest resulted in limited southward-directed pathways from sources within the North Head study area towards Benson Beach. No pathways 

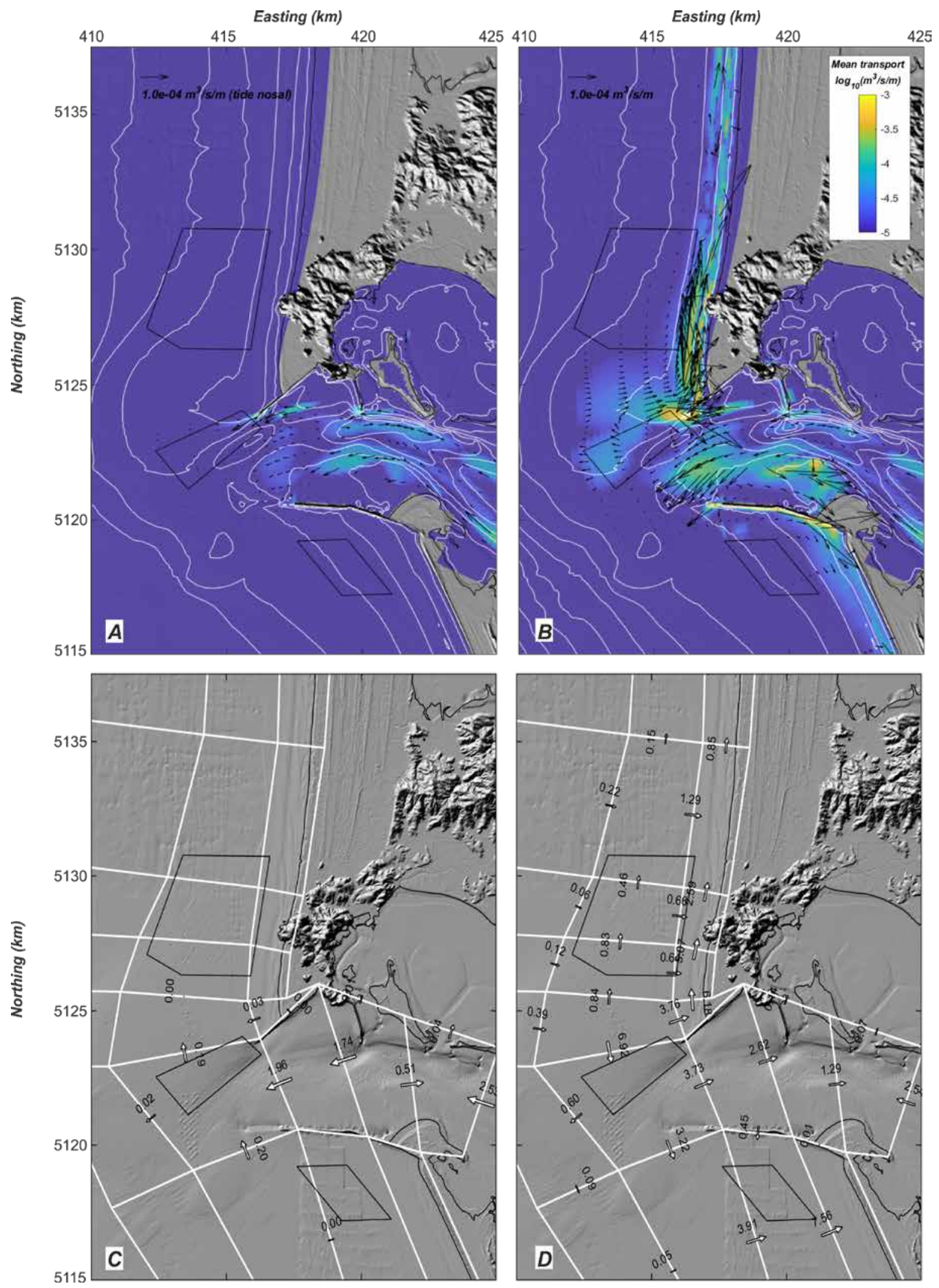

Figure 33. Maps showing annually averaged sediment-transport fluxes that are based on schematized model simulations during low $\left(4,000 \mathrm{~m}^{3} / \mathrm{s}\right)$ fluvial-discharge scenarios. Sediment-transport vectors (black arrows) are provided for simulations forced $(A)$ with tides and fluvial discharge alone and $(B)$ with tides, fluvial discharge, and waves; lengths of vectors are scaled to length $\left(1.0 \times 10^{-4} \mathrm{~m}^{3} / \mathrm{s} / \mathrm{m}\right)$ of black arrow in upper right corner of $A$. Transect-averaged sediment fluxes (white-filled arrows) are shown for simulations forced $(C)$ with tides and fluvial discharge alone and $(D)$ with tides, fluvial discharge, and waves; white boxes show locations of transects; numeric values next to arrows in $C$ and $D$ represent transect-averaged sediment-transport fluxes, in thousands of $\mathrm{m}^{3}$ per tide. Black boxes show locations of dredge-placement sites. Other abbreviations: km, kilometer(s); m, meter(s); s, second. 

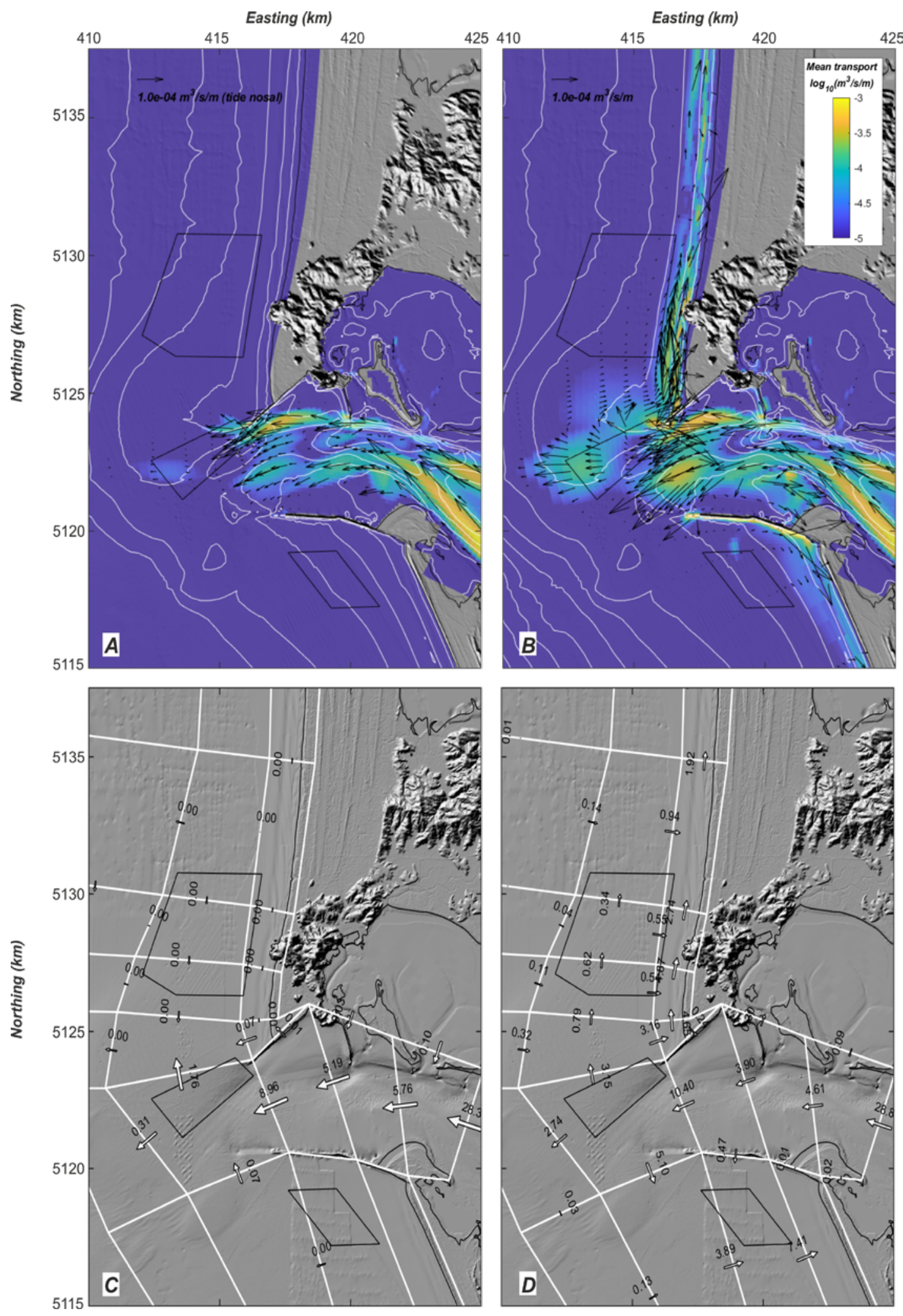

Figure 34. Maps showing annually averaged sediment-transport fluxes that are based on schematized model simulations during high $\left(8,000 \mathrm{~m}^{3} / \mathrm{s}\right)$ fluvial-discharge scenarios. Sediment-transport vectors (black arrows) are provided for simulations forced $(A)$ with tides and fluvial discharge alone and $(B)$ with tides, fluvial discharge, and waves; lengths of vectors are scaled to length $\left(1.0 \times 10^{-4} \mathrm{~m}^{3} / \mathrm{s} / \mathrm{m}\right)$ of black arrow in upper right corner of $A$. Transect-averaged sediment fluxes (white-filled arrows) are shown for simulations forced $(C)$ with tides and fluvial discharge alone and $(D)$ with tides, fluvial discharge, and waves; white boxes show locations of transects; numeric values next to arrows in $C$ and $D$ represent transect-averaged sediment-transport fluxes, in thousands of $\mathrm{m}^{3}$ per tide. Black boxes show locations of dredge-placement sites. Other abbreviations: km, kilometer(s); m, meter(s); s, second. 


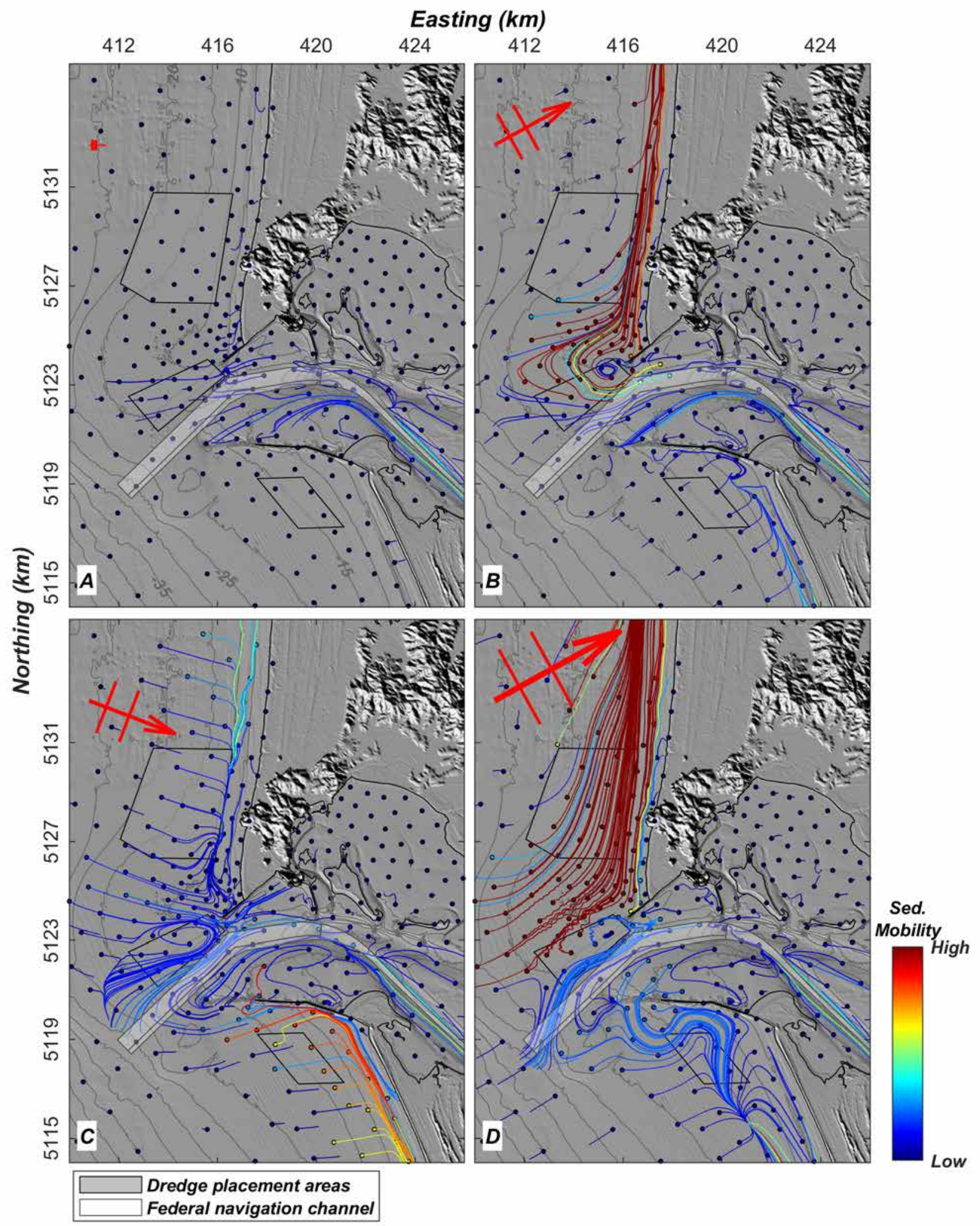

Figure 35. Maps showing sediment-transport pathways (colored lines) derived from application of Sediment Pathways Interactive visualization Tool (SPIT) to schematized model simulations using low-river-discharge conditions and constant wave forcing. Maps $A-D$ show wave classes 13,18,10, and 11, respectively (see table 5 for specifications of wave classes). Black dots indicate initial positions of sediment sources; colors of sediment pathways indicate relative mobility of sources. Red arrows in upper left corners denote incident wave directions at offshore locations modeled in scenario. Abbreviation: km, kilometer(s). 


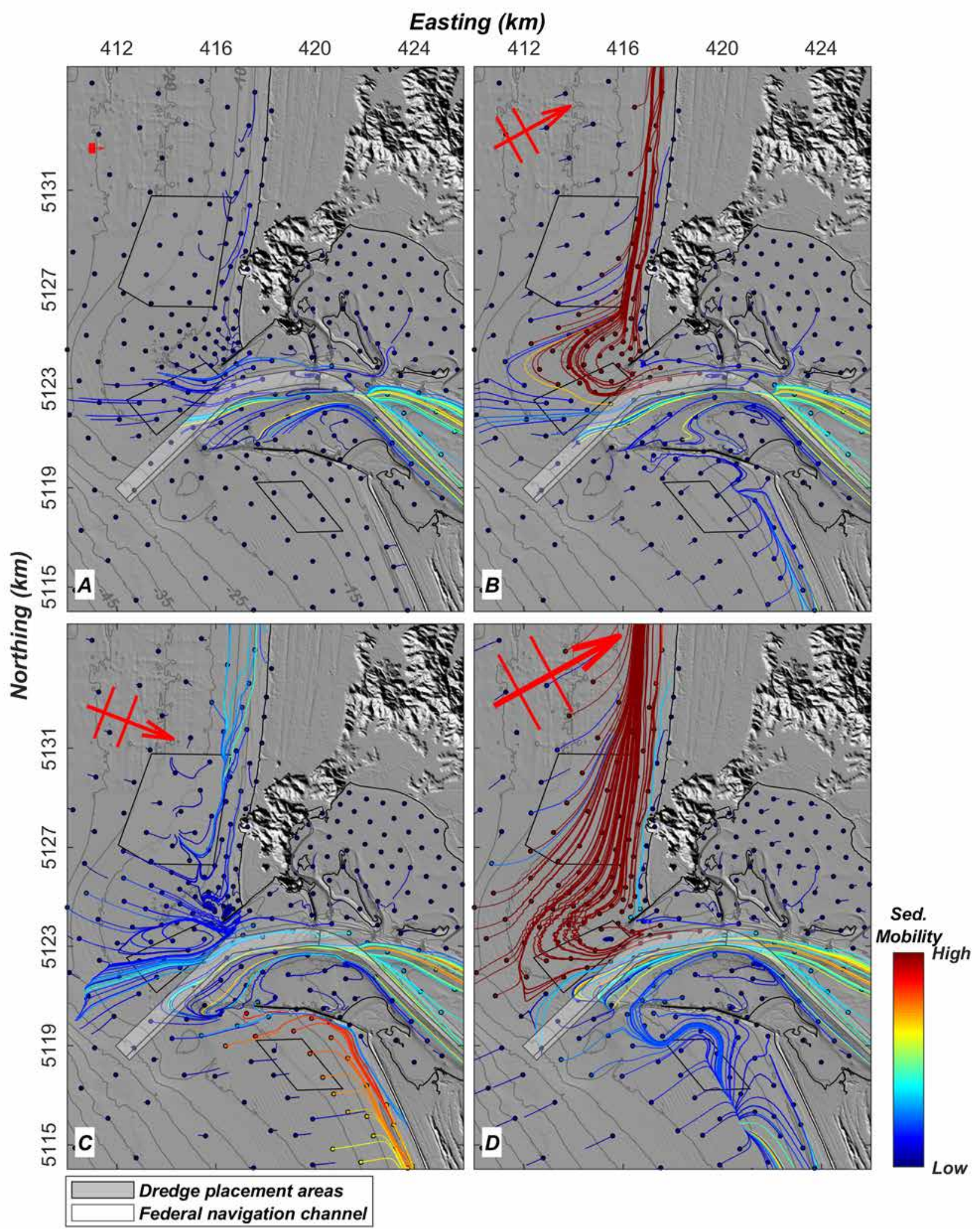

Figure 36. Maps showing sediment-transport pathways (colored lines) derived from application of Sediment Pathways Interactive visualization Tool (SPIT) to schematized model simulations using highriver-discharge conditions and constant wave forcing. Maps $A-D$ show wave classes $13,18,10$, and 11 , respectively (see table 5 for specifications of wave classes). Black dots indicate initial positions of sediment sources; colors of sediment pathways indicate relative mobility of sources. Red arrows in upper left corners denote incident wave directions at offshore locations modeled in scenario. Abbreviation: $\mathrm{km}$, kilometer(s). 
that originate from within the North Head study area interact with the inlet, regardless of wave direction, suggesting that dredged material placed within the North Head study area is unlikely to contribute to shoaling in the navigational channel.

A primary objective of the placement of dredged material in the nearshore is to supplement the sediment budget and mitigate erosion of beaches and associated coastal change hazards in proximity to the inlet. According to baseline monitoring of beach nearshore morphology as described in Task 1, Benson Beach eroded approximately $2.1 \mathrm{Mm}^{3}$ $\left(420,000 \mathrm{~m}^{3} / \mathrm{yr}\right)$ between 2014 and 2019 (table 3). Analysis of sediment-transport pathways was performed to identify source regions that can supply sediment to Benson Beach. Sources that have pathways that intersect Benson Beach were

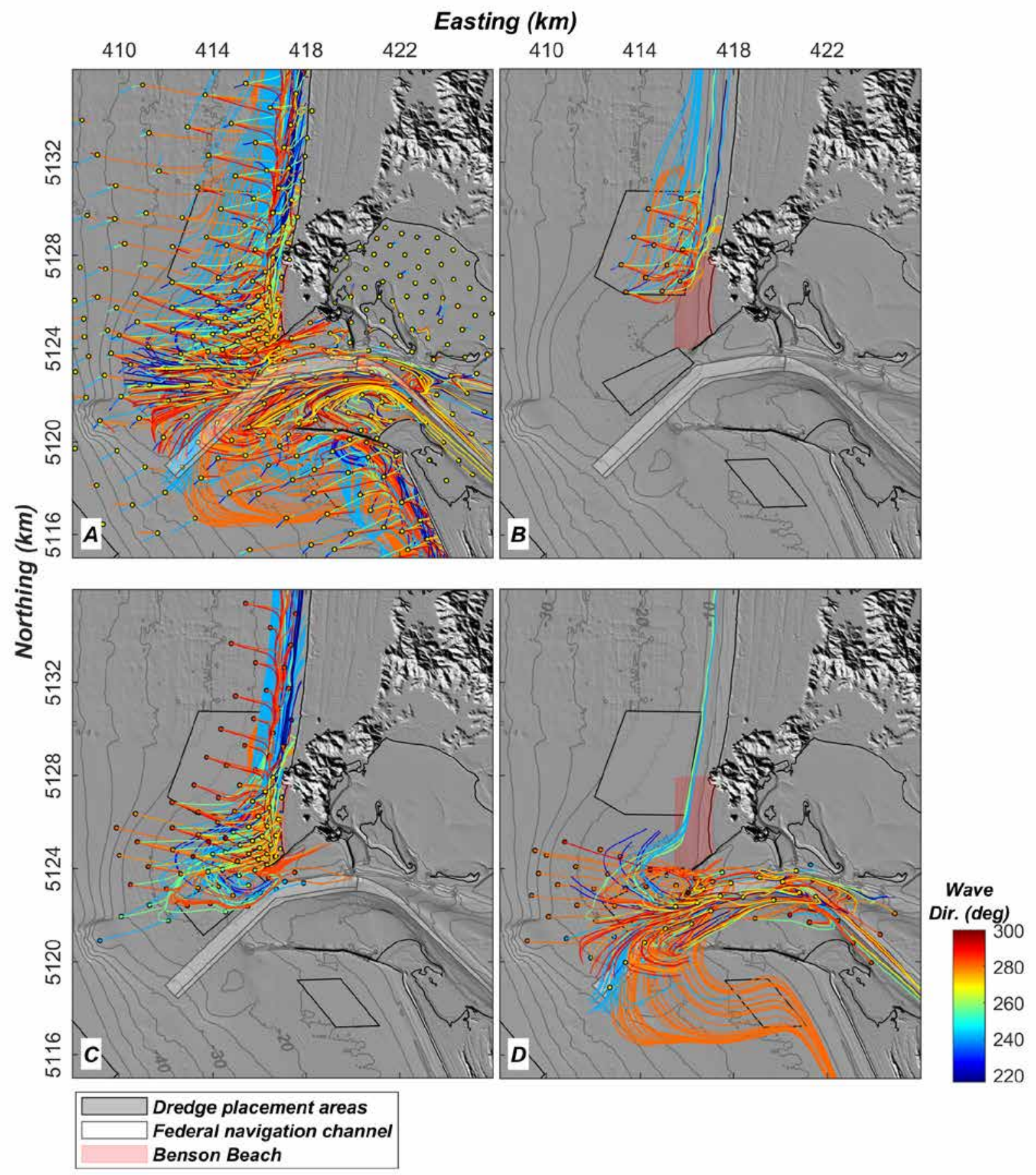

Figure 37. Maps showing sediment-transport pathways (colored lines) calculated for various sediment-source locations (white dots) and polygons of interest for low-river-discharge scenario. $A$, All 500 sources and 19 wave classes. $B$, Sources from all wave classes originating from within North Head study area. $C$, Sources and wave classes for pathways that interact with Benson Beach. $D$, Sources and wave classes for pathways that interact with navigational channel. Black dots indicate initial positions of sediment sources; colors of sediment pathways indicate direction from which waves were directed. Abbreviations: deg, degree(s); km, kilometer(s). 
located on the north side of the MCR, as well as throughout the northern ebb-tidal delta, including both the Shallow Water Site dredge-placement area and the North Head study area (fig. 37C). However, only wave conditions from the northwest produced sediment-transport pathways between the North Head study area and Benson Beach, suggesting that limited connectivity between the two exists. On the other hand, sediment-transport pathways from sources that originate within the Shallow Water Site, as well as from the ebb-tidal delta between the Shallow Water Site and North Head study area, intersected Benson Beach under a variety of wave conditions. The total probability, or percent of time, that sedimenttransport pathways from each source location interacted with
Benson Beach (fig. 38) suggests that areas along the ebb-tidal delta between the inlet and North Head study area are more often connected to Benson Beach. The total probability of interaction for each source was calculated by summing the number of wave classes that have pathways that intersect Benson Beach multiplied by the wave class probability of occurrence (table 5). This analysis suggests that placement of dredged material in the region between the Shallow Water Site and North Head study area would more directly and efficiently enhance the sediment budget of Benson Beach.

Some sediment transport pathways from source regions originating along the ebb delta, including those within the Shallow Water Site dredge placement area, interacted with the

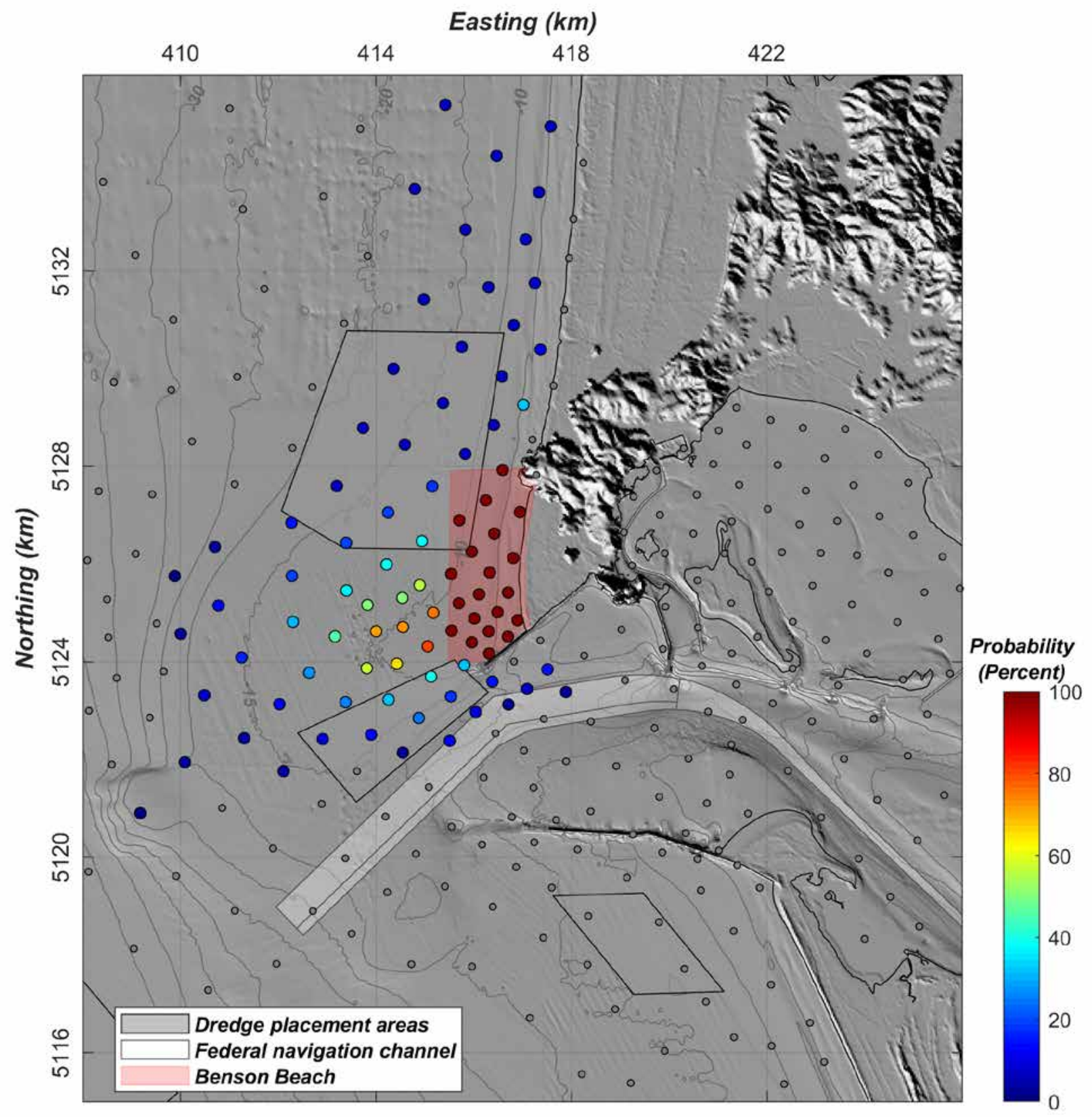

Figure 38. Probabilities (colored dots) of sediment-transport-pathway interactions between each source region and Benson Beach during low-river-discharge conditions. Gray dots indicate sediment-source locations with that have zero probability of occurrence. Abbreviation: km, kilometer(s). 
navigation channel (fig. 37D). This suggests the possibility that dredged sediment placed in these regions may be transported back into the navigation channel. However, the total probability that sediment transport pathways between sources located within the Shallow Water Site and other locations on the ebb delta was generally low (fig. 39). As noted above, none of the pathways with sources originating within the North Head study area interacted with the navigation channel under any of the wave conditions that were simulated.

\section{Concluding Remarks}

A total of 2,560 km of nearshore bathymetric survey lines and 2,837 km of topographic survey lines were collected during the six surveys performed between 2014 and 2019. Throughout the entire CRLC survey area, the only significant regional erosion pattern was observed at Benson Beach, on the north side of the Columbia River. Despite the placement of approximately $6.3 \mathrm{Mm}^{3}$ of sand dredged from the Columbia

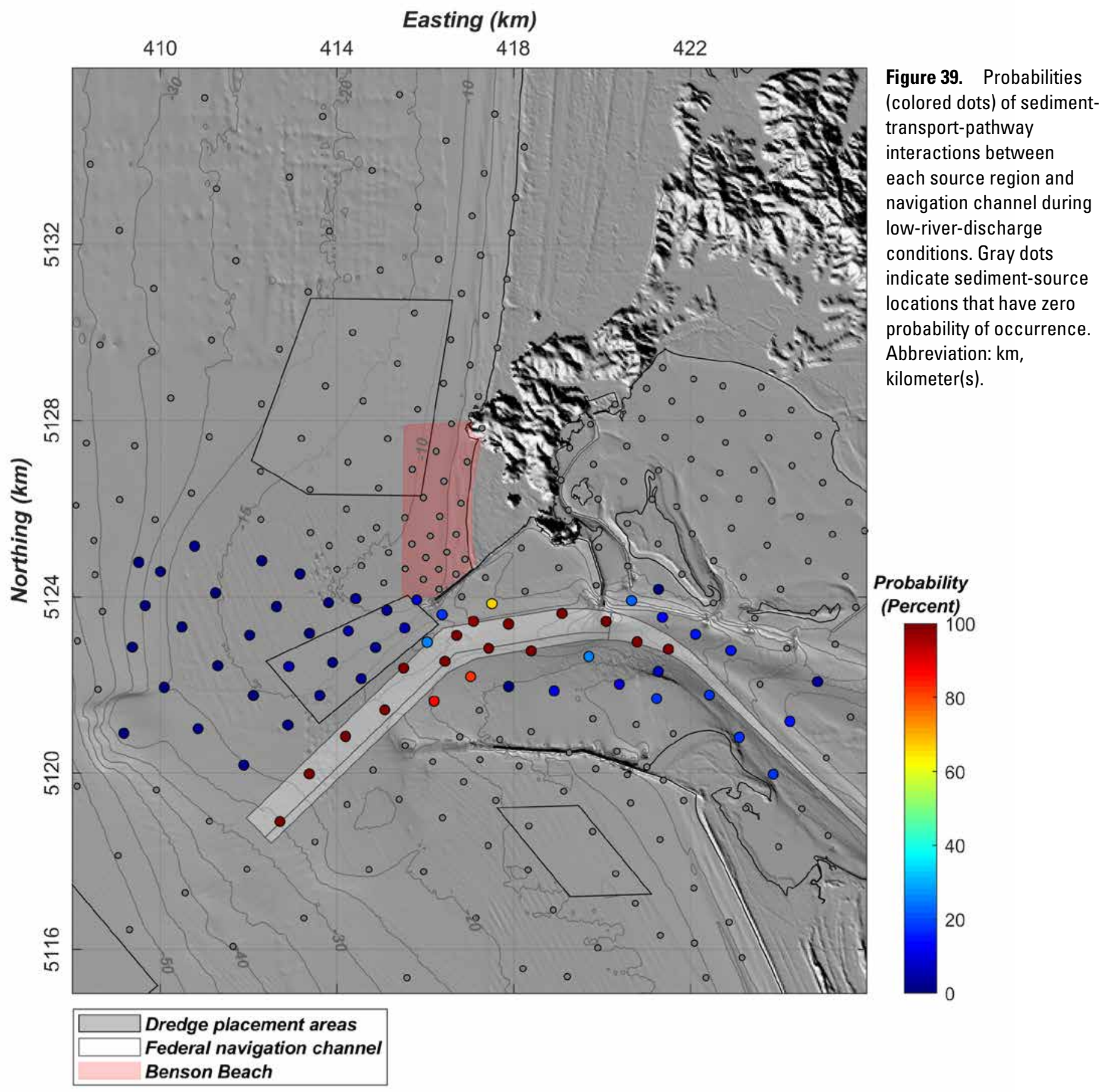


River navigational channel at nearshore dredge-placement sites located nearby, Benson Beach eroded $2.1 \pm 0.8 \mathrm{Mm}^{3}$ $\left(420,000 \mathrm{~m}^{3} / \mathrm{yr}\right)$ during the monitoring time period. The dredged material placed within the Shallow Water Site likely contributed to accumulation that was observed in the nearshore at the south end of the Benson Beach region. However, our results suggest that additional nourishment is needed to mitigate the $420,000 \mathrm{~m}^{3} / \mathrm{yr}$ deficit in sediment supply to the Benson Beach region and reverse the steady erosional trend of the nearshore and beach.

The persistent erosion-despite the enhanced sediment supply-observed at Benson Beach highlights the need for efficient delivery of sediment from the nearshore dredgeplacement sites to the eroding beach and nearshore areas. In this study, an innovative, new numerical modeling method was developed to simulate sediment-transport fluxes and evaluate the linkages between nearshore dredge-placement areas and adjacent coastlines. The core of this model consisted of a coupled Delft3D-SWAN hydrodynamic, wave, and sedimenttransport model that was validated with extensive field measurements. Sediment-transport pathways were visualized and linkages were quantified using the Sediment Pathway Interactive visualization Tool (SPIT).

Model results indicate the dominant importance of wave processes on sediment-transport patterns outside of the inlet and also that the North Head study area is not well situated to efficiently enhance the sediment budget of Benson Beach as currently configured. Sediment-transport pathways from sources that originate within the North Head study area were primarily directed onshore and northward, suggesting that sediment placed within the North Head study area will bypass Benson Beach and be transported toward the Long Beach peninsula. Sediment-transport pathways that originate from the northeastern part of the Shallow Water Site interacted with Benson Beach during a wider range of wave conditions, and yet these sediment-source locations also interacted with the navigation channel. Our analysis suggests that the region along the ebb-tidal delta between the Shallow Water Site and North Head study area would be best situated to enhance the sediment budget of Benson Beach without a high probability of sediment placed in this area being transported back into the navigation channel.

\section{Data Availability}

Data files - including all of the bathymetric and topographic data and associated metadata described in this report-are provided in Stevens and others (2019). In addition, Stevens and others (2017) provided data files and associated metadata that describe the collection and processing of timeseries oceanographic data used to validate the hydrodynamic model applied in this study.

\section{References Cited}

Akan, C., Moghimi, S., Ozkan-Haller, H.T., Osborne, J., and Kurapov, A., 2017, On the dynamics of the Mouth of the Columbia River-Results from a three-dimensional fully coupled wave-current interaction model: Journal of Geophysical Research Oceans, v. 122, p. 5218-5236.

Anderson, D., Ruggiero, P., Antolínez, J.A.A., Méndez, F.J., and Allan, J., 2018, A climate index optimized for longshore sediment transport reveals interannual and multidecadal littoral cell rotations: Journal of Geophysical Research Earth Surface, v. 123, p. 1958-1981.

Anderson, S.W., 2019, Uncertainty in quantitative analyses of topographic change-Error propagation and the role of thresholding: Earth Surface Processes and Landforms, v. 44, p. 1015-1033.

Atwater, B.F., 1996, Coastal evidence for great earthquakes in western Washington, in Rogers, A.M., Walsh, T.J., Kockelman, W.J., and Priest, G.R., eds., Assessing earthquake hazards and reducing risk in the Pacific Northwest, volume 1: U.S. Geological Survey Professional Paper 1560, v. 1, p. 77-90, https://doi.org/10.3133/pp1560 voll.

Barnard, P.L., Hoover, D., Hubbard, D.M., Snyder, A., Ludka, B.C., Allan, J., Kaminsky, G.M., Ruggiero, P., Gallien, T.W., Gabel, L., McCandless, D., Weiner, H.M., Cohn, N., Anderson, D.L., and Serafin, K.A., 2017, Extreme oceanographic forcing and coastal response due to the 20152016 El Niño: Nature Communications, v. 8, p. 1-8.

Barnard, P.L., Short, A.D., Harley, M.D., Splinter, K.D., Vitousek, S., Turner, I.L., Allen, J., Banno, M., Bryan, K.R., Doria, A., Hansen, J.E., Kato, S., Kuriyama, Y., Randal-Goodwin, E., Ruggiero, P., Walker, I.J., and Heathfield, D.K., 2015, Coastal vulnerability across the Pacific dominated by El Nino/Southern Oscillation: Nature Geoscience, v. 8, p. 801-807.

Booij, N., Ris, R.C., and Holthuijsen, L.H., 1999, A thirdgeneration wave model for coastal regions, Part I-Model description and validation: Journal of Geophysical Research, v. 104, p. 7649-7666.

Cohn, N., and Ruggiero, P.R., 2016, The influence of seasonal to interannual nearshore profile variability on extreme water levels-Modeling wave runup on dissipative beaches: Coastal Engineering, v. 115, p. 79-92.

Daniels, R.C., Ruggiero, P., and Weber, L.E., 1999, Washington coastal geodetic control network - Report and station index: Washington Department of Ecology, Coastal Monitoring \& Analysis Program, Publication \#99-103, 268 p. 
Davis, J.C., 2002, Statistics and data analysis in geology (3d ed.): New York, Wiley \& Sons, 638 p.

Deltares, 2016, D-Waq PART User Manual-Simulation of mid-field water quality and oil spills, using particle tracking: Delft, The Netherlands, Deltares Technical Report, 144 p.

Egbert, G.D., and Erofeeva, S.Y., 2002, Efficient inverse modeling of barotropic ocean tides: Journal of Atmospheric and Oceanic Technology, v. 19, p. 183-204.

Elias, E., and Gelfenbaum, G., 2009, Modeling processes controlling sediment transport at the mouth of the Columbia River: Proceedings of Coastal Dynamics 2009, Paper No. 68, https://doi.org/10.1142/9789814282475_0070.

Elias, E.P.L., Gelfenbaum, G., and Westhuysen, van der A.J., 2012, Validation of a coupled wave-flow model in a highenergy setting - The mouth of the Columbia River: Journal of Geophysical Research, v. 117, p. C09011.

Gelfenbaum, G., Elias, E., and Stevens, A.W., 2017, Investigation of input reduction techniques for morphodynamic modeling of complex inlets with baroclinic forcing: Proceedings of Coastal Dynamics 2017, Paper No. $260,13 \mathrm{p}$.

Gelfenbaum, G., Stevens, A.W., Miller, I., Warrick, J.A., Ogston, A.S., and Eidam, E., 2015a, Large-scale dam removal on the Elwha River, Washington, USA - Coastal geomorphic change: Geomorphology, v. 246, p. 649-668.

Gelfenbaum, G.R., Finlayson, D.P., Dartnell, P., Carlson, E., and Stevens, A.W., 2015b, Bathymetry and backscatter from 2013 interferometric swath bathymetry systems survey of Columbia River Mouth, Oregon and Washington: U.S. Geological Survey data release, https://doi.org/10.5066/ F7T72FHB.

Jay, D.A., Leffler, K.L., Diefenderfer, H.L., and Borde, A.B., 2015, Tidal-fluvial and estuarine processes in the lower Columbia River-I. Along-channel water level variation, Pacific Ocean to Bonneville Dam: Estuaries and Coasts, v. 38, p. 415-433.

Joliff, J.K., Kindle, J.C., Shulman, I., Penta, B., Friedrichs, M.A.M., Helber, R., and Arnone, R.A., 2009, Summary diagrams for coupled hydrodynamic-ecosystem model skill assessment: Journal of Marine Systems, v. 76, p. 64-82.

Kalnay, E., Kanmitsu, M., Kistler, R., Collins, W., Deaven, D., Gandin, L., Iredell, M., Saha, S., White, G., Woollen, J., Zhu, Y., Chelliah, M., Ebisuzaki, W., Higgens, W., Janowiak, J., Mo, K.C., Ropelewski, C., Wang, J., Leetmaa, A., Reynolds, R., Jenne, R., and Joseph, D., 1996, The NCEP/NCAR 40-Year reanalysis project: Bulletin of the American Meteorological Society, v. 77, p. 437-471.

Kaminsky, G.M., Ruggiero, P., Buijsman, M.C., McCandless, D., and Gelfenbaum, G., 2010, Historical evolution of the Columbia River littoral cell: Marine Geology, v. 273, p. 96-126.
Karna, T., Baptista, A.M., Lopez, J.E., Turner, P.J., McNeil, C., and Sanford, T.B., 2015, Numerical modeling of circulation in high-energy estuaries - A Columbia River estuary benchmark: Ocean Modeling, v. 88, p. 54-71.

Lesser, G.R., 2009, An approach to medium term coastal morphological modelling: Delft, Netherlands, Delft Technical University, Ph.D. Dissertation, 239 p.

Lesser, G.R., Roelvink, J.A., van Kester, T.M., and Stelling, G.S., 2004, Development and validation of a threedimensional morphological model: Coastal Engineering, v. 51, p. 883-915.

Love, M.R., Friday, D.Z., Grothe, P.R., Carignan, K.S., Eakins, B.W., and Taylor, L.A., 2012, Digital elevation model of Astoria, Oregon-Procedures, data sources and analysis: National Oceanic and Atmospheric Administration, National Geophysical Data Center, 30 p.

Lower Columbia Estuary Partnership, 2010, Lower Columbia River digital terrain model: Lower Columbia Estuary Partnership website, https://www.estuarypartnership.org/ lower-columbia-digital-terrain-model.

MacDonald, N.J., Davies, M.H., Zundel, A.K., Howlett, J.D., Demirbilek, Z., Gailani, J.Z., Lackey, T.C., and Smith, J., 2006, PTM-Particle tracking model, Report 1Model theory, implementation, and example applications: U.S. Army Corps of Engineers Engineer Research and Development Center Technical Report ERDC/CHL TR-0620, 169 p.

MacMahan, J., 2016, Observations of oceanic-forced subtidal elevations in a convergent estuary: Estuarine, Coastal and Shelf Science, v. 181, p. 319-324.

Mass, C., 2008, The weather of the Pacific Northwest: Seattle, University of Washington Press, 280 p.

Mote, P.W., Rupp, D.E., Li, S., Sharp, D.J., Otto, F., Uhe, P.F., Xiao, M., Lettenmaier, D.P., Cullen, H., and Allen, M.R., 2016, Perspectives on the causes of exceptionally low 2015 snowpack in the western United States: Geophysical Research Letters, v. 43, p. 10,980-10,988.

Peterson, C.D., Vanderburgh, S., Roberts, M.C., Jol, H.M., Phipps, J., and Twichell, D.C., 2010, Composition, age, and depositional rates of shoreface deposits under barriers and beach plains of the Columbia River littoral cell, USA: Marine Geology, v. 273, p. 62-82.

Ranasinghe, R., McLoughlin, R., Short, A., and Symonds, G., 2004, The Southern Oscillation Index, wave climate, and beach rotation: Marine Geology, v. 204, p. 273-287.

Ruggiero, P., Kaminsky, G.M., Gelfenbaum, G., and Cohn, N., 2016, Morphodynamics of prograding beaches - A synthesis of seasonal- to century-scale observations of the Columbia River littoral cell: Marine Geology, v. 376, p. 51-68. 
Ruggiero, P., Kaminsky, G.M., Gelfenbaum, G., and Voigt, B., 2005, Seasonal to interannual morphodynamics along a high-energy dissipative littoral cell: Journal of Coastal Research, v. 21, p. 553-578.

Ruggiero, P., Komar, P.D., and Allan, J.C., 2010, Increasing wave heights and extreme value projections - The wave climate of the U.S. Pacific Northwest: Coastal Engineering, v. 57, p. 539-552.

Sherwood, C.R., and Creager, J.S., 1990, Sedimentary geology of the Columbia River estuary: Progress in Oceanography, v. 25, p. 15-79.

Sherwood, C.R., Jay, D.A., Harvey, R.B., Hamilton, P., and Simenstad, C.A., 1990, Historical changes in the Columbia River Estuary: Progress in Oceanography, v. 25, p. 299-352.

Snyder, A.G., Lacy, J.R., Stevens, A.W., and Carlson, E.M., 2016, Bathymetric survey and digital elevation model of Little Holland Tract, Sacramento-San Joaquin Delta, California: U.S. Geological Survey Open-File Report 2016-1093, 14 p., https://doi.org/10.3133/ofr20161093.

Soulsby, R.L., Mead, C.T., Wild, B.R., and Wood, M.J., 2011, Lagrangian model for simulating the dispersal of sandsized particles in coastal waters: Journal of Waterway, Port, Coastal and Ocean Engineering, v. 137, no. 3, p. 123-131.

Stevens, A.W., Gelfenbaum, G., MacMahan, J., Reniers, A.J.H.M., Elias, E.P., Sherwood, C.R., and Carlson, E.M., 2017, Oceanographic measurements and hydrodynamic modeling of the mouth of the Columbia River, Oregon and Washington, 2013: U.S. Geological Survey data release, https://doi.org/10.5066/F7NG4NS1.

Stevens, A.W., Gelfenbaum, G., Ruggiero, P., and Kaminsky, G.M, 2012, Southwest Washington littoral drift restoration-Beach and nearshore morphological monitoring: U.S. Geological Survey Open-File Report 2012-1175, 67 p., https://pubs.usgs.gov/of/2012/1175/.

Stevens, A.W., Weiner, H.M., Ruggiero, P., Kaminsky, G.M., and Gelfenbaum G.R., 2019, Beach topography and nearshore bathymetry of the Columbia River littoral cell, Washington and Oregon (ver. 2.0, November 2019): U.S. Geological Survey data release, https://doi.org/10.5066/ P9W15JX8.
Storlazzi, C.D., van Ormondt, M., Chen, Y-L., and Elias, E.P.L., 2017, Modeling fine-scale coral larval dispersal and interisland connectivity to help designate mutuallysupporting coral reef Marine Protected Areas-Insights from Maui Nui, Hawaii: Frontiers in Marine Science, v. 4, p. 1-14.

Taylor, J.R., 1997, An introduction to error analysis (2d ed.): Sausalito, Calif., University Science Books.

U.S. Army Corps of Engineers (USACE), 2019, Management of open water dredged material placement/disposal sites, Mouth of the Columbia River, OR and WA: 2019 Annual Use Plan, $97 \mathrm{p}$.

Vriend, de H.J., Capobianco, M., Chesher, T., de Swart, H.E., Latteux, B., and Stive, M.J.F., 1993, Approaches to longterm modelling of coastal morphology-A review: Coastal Engineering, v. 21, p. 225-269.

Van Rijn, L.C., 2007a, Unified view of sediment transport by currents and waves - I. Initiation of motion, bed roughness, and bed-load transport: Journal of Hydraulic Engineering, $\mathrm{v}$. 133 , p. 19.

Van Rijn, L.C., 2007b, Unified view of sediment transport by currents and waves-II. Suspended transport: Journal of Hydraulic Engineering, v. 133, p. 22.

Van Rijn, L.C., 2007c, Unified view of sediment transport by currents and waves-III. Graded beds: Journal of Hydraulic Engineering, v. 133, p. 15.

Warrick, J.A., Stevens, A.W., Miller, I.M., Harrison, S.R., and Gelfenbaum, G., 2019, World's largest dam removal reverses coastal erosion: Scientific Reports, v. 9, no. 13968, 12 p., https://doi.org/10.1038/s41598-019-50387-7.

Westhuysen, van der A.J., 2007, Advances in the spectral modeling of wind waves in the nearshore: Delft, Netherlands, Delft University of Technology, Ph.D. dissertation, $209 \mathrm{p}$.

Xu, J., Myers, E., and White, S., 2010, VDatum for the coastal waters of North/Central California, Oregon and Western Washington-Tidal datums and sea surface topography: National Oceanic and Atmospheric Administration Technical Memorandum NOS CS 22, 68 p. 



\section{Appendix 1. Coverage Maps, Environmental Conditions, and Water-Column Properties During Bathymetric and Topographic Surveys}

In this appendix, we provide maps that show survey lines, time-series plots that show tide heights and wave conditions during data acquisition, and water-column properties derived from Conductivity Temperature Depth (CTD) casts collected during bathymetric and topographic surveys performed along the Columbia River littoral cell (CRLC) between 2014 and 2019.

$-124.2^{\circ}$

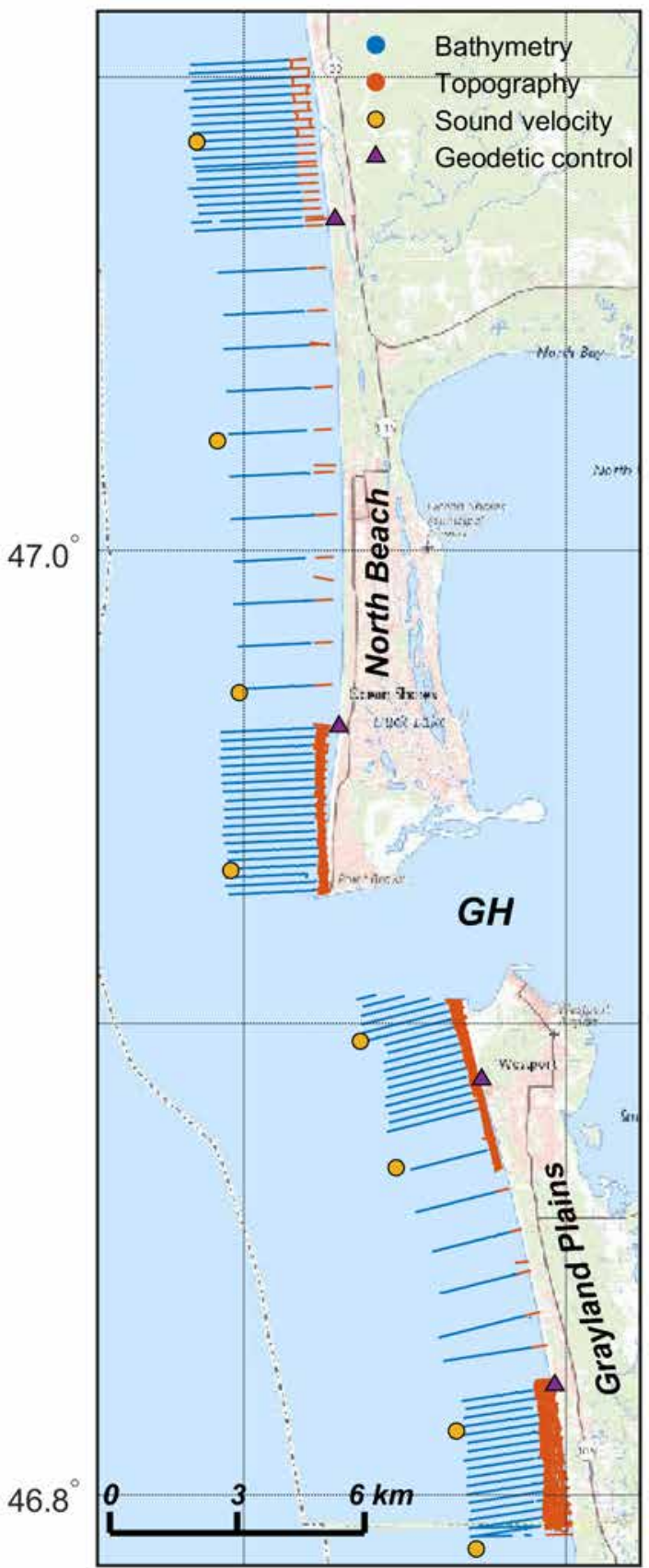

$-124.0^{\circ}$

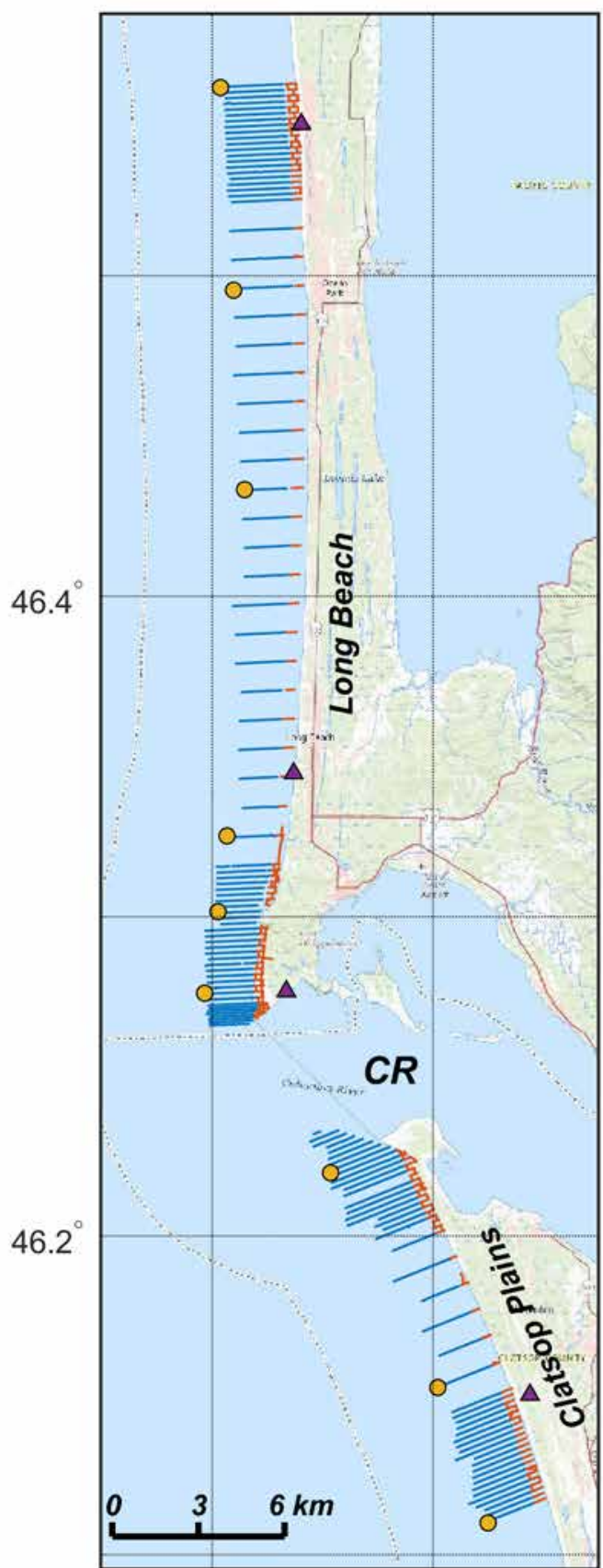

Figure A1. Maps showing locations of bathymetric- and topographic-survey lines (blue and red lines, respectively), sound-velocity measurements derived from Conductivity Temperature Depth casts, and benchmarks used for geodetic control from 2014 surveys along Columbia River littoral cell; left and right panels show data coverage for northern and southern parts of study area, respectively. Abbreviations: CR, Columbia River; GH, Grays Harbor; km, kilometer(s). 

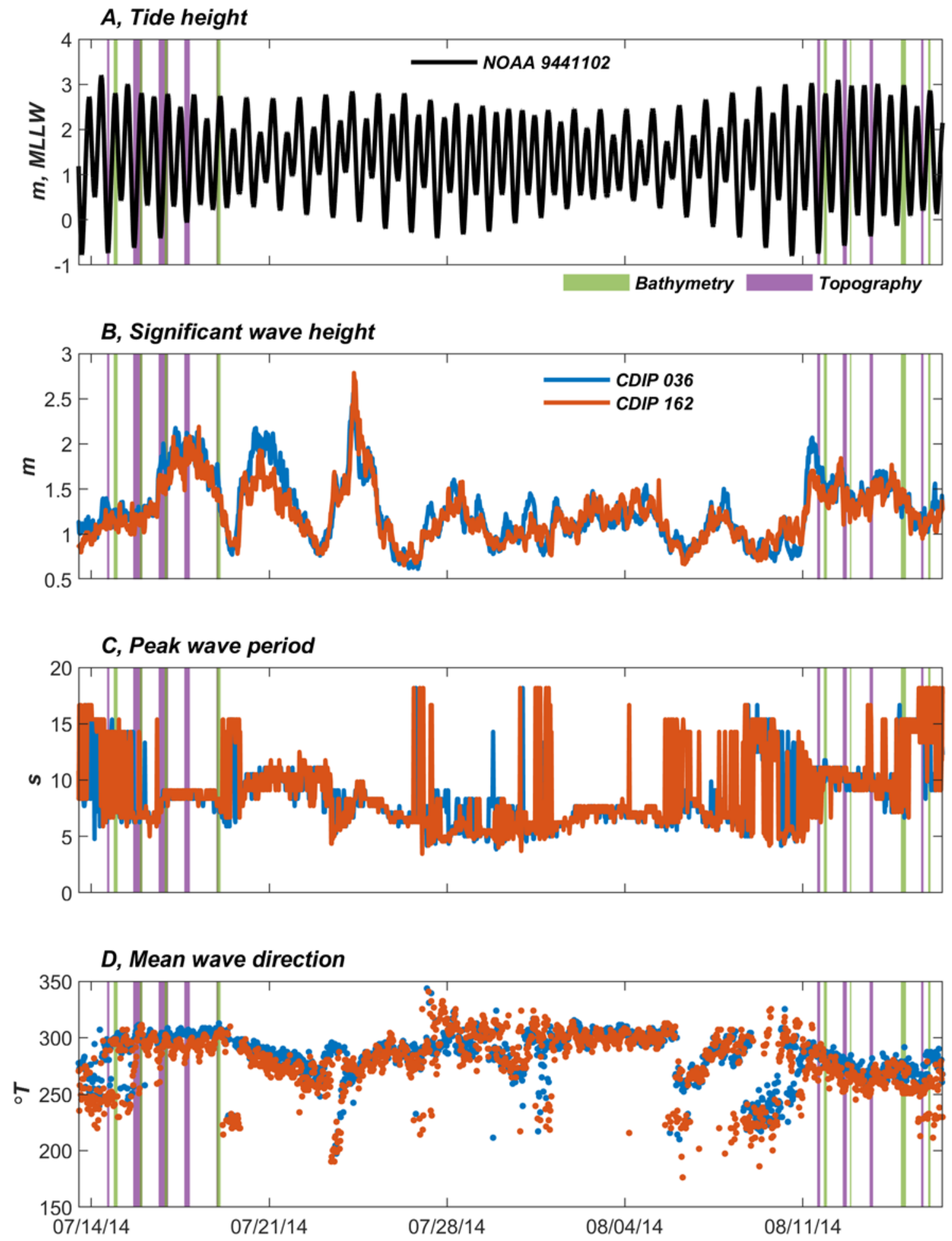

Figure A2. Time-series plots of $(A)$ water levels, $(B)$ wave heights, $(C)$ wave periods, and $(D)$ wave directions during 2014 bathymetric and topographic surveys of Columbia River littoral cell; green and purple shading shows timing of bathymetric- and topographic-data collections, respectively. Abbreviations: CDIP, Coastal Data Information Program; km, kilometer(s); m, meter(s); MLLW, mean lower low water; NOAA, National Oceanic and Atmospheric Administration; s, second(s); ${ }^{\circ} T$, degree(s) true north. 
$A$

$-124.2^{\circ}-124.0^{\circ}$

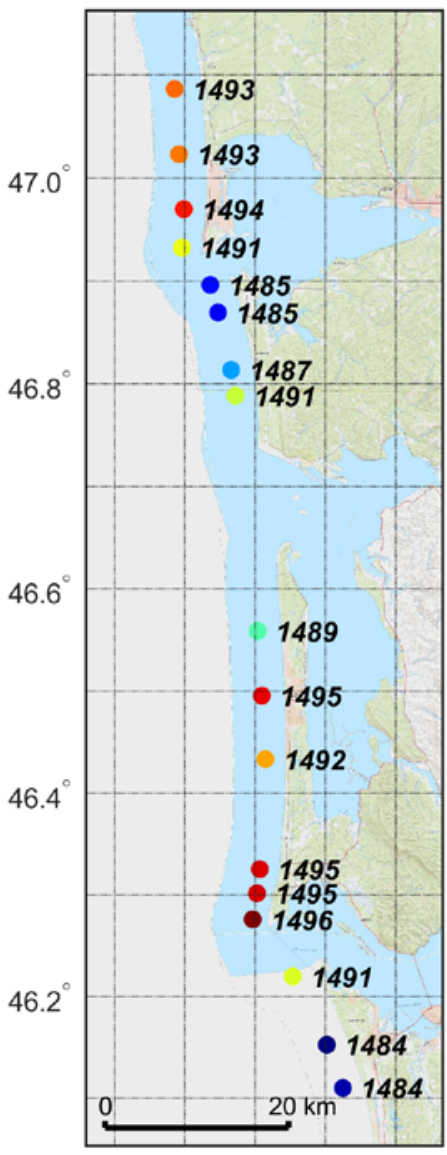

\section{B}

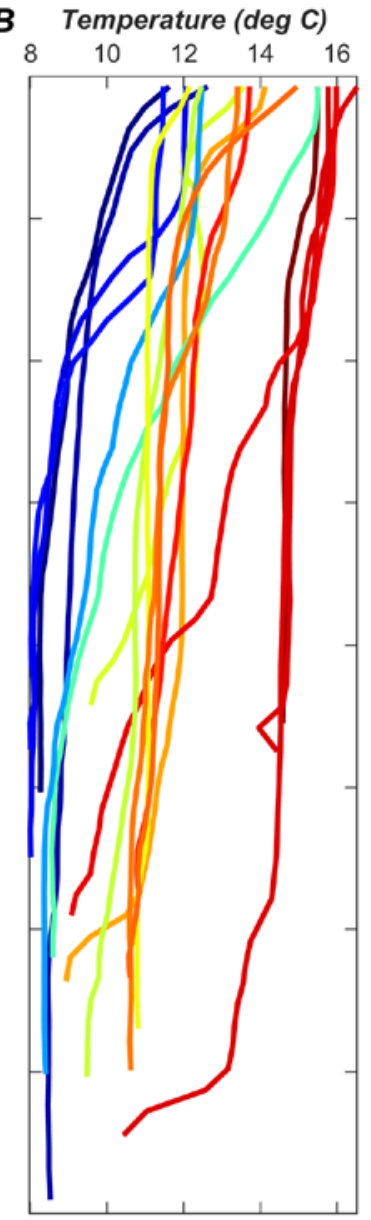

$c$

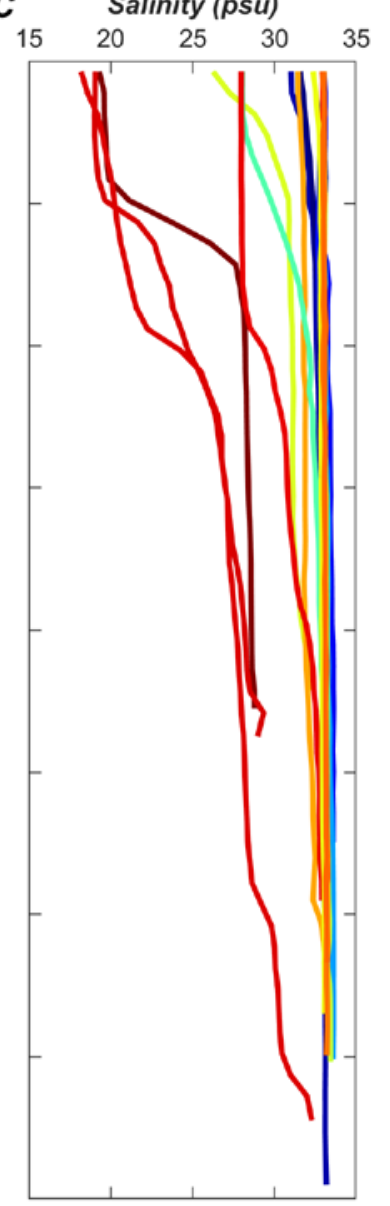

D Sound Velocity $(\mathrm{m} / \mathrm{s})$

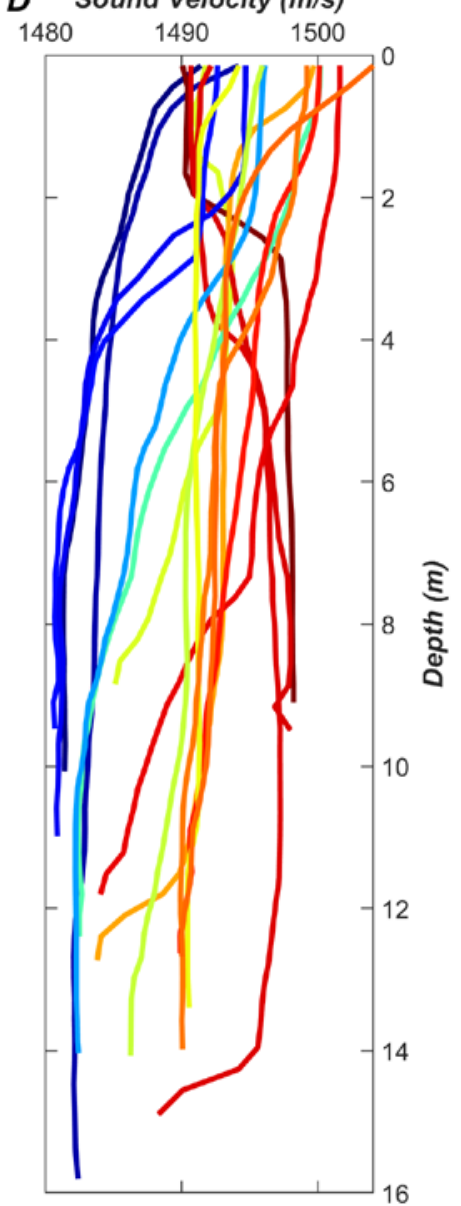

Figure A3. A, Map showing locations (colored dots) of Conductivity Temperature Depth casts collected during 2014 bathymetric surveys; numbers represent depth-averaged sound velocities. Depth profiles of water-column properties were measured during each cast, including $(B)$ temperature, $(C)$ salinity, and $(D)$ sound velocity. Abbreviations: deg $C$, degrees Celsius; km, kilometer(s); m, meter(s); psu, practical salinity unit(s); s, second. 

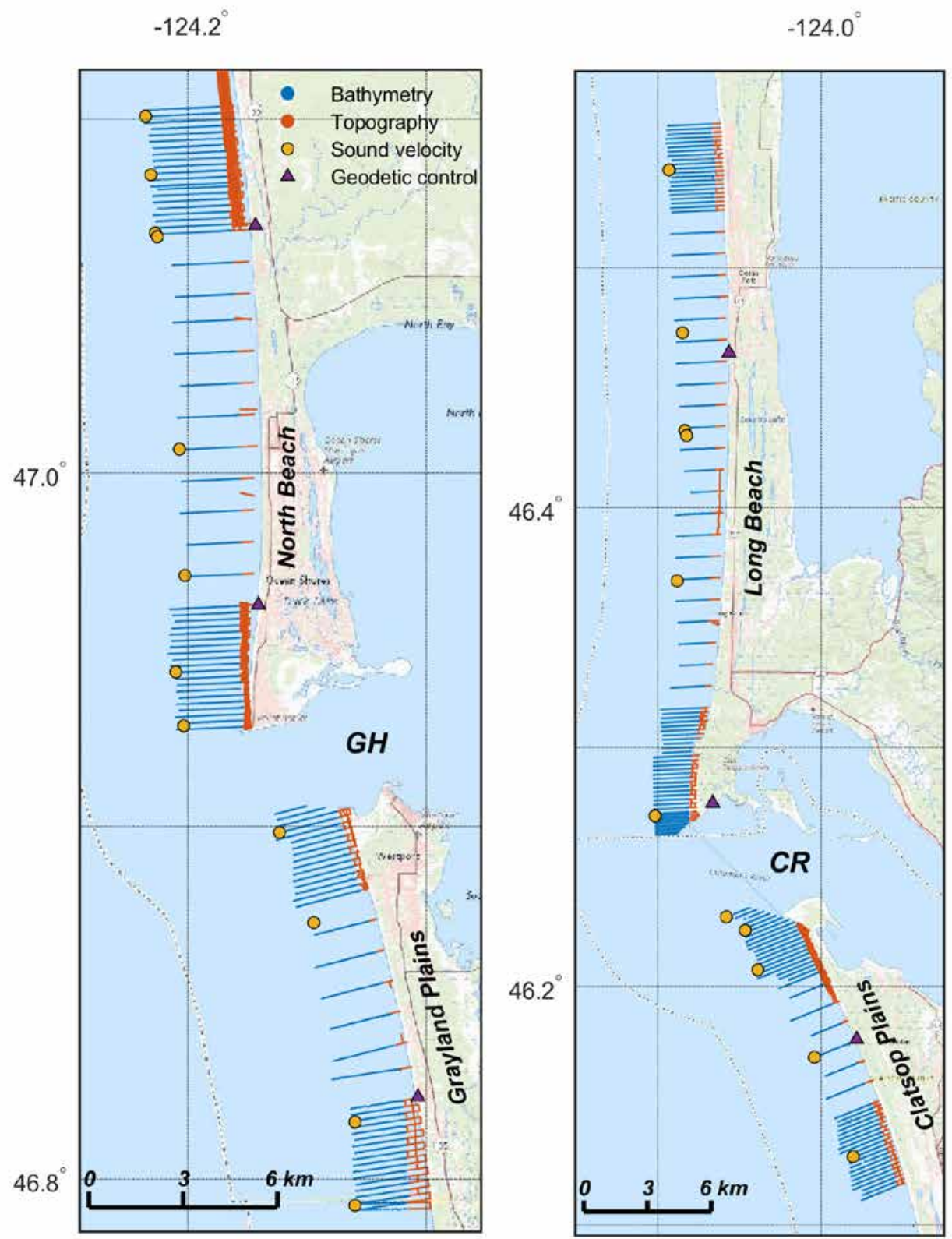

Figure A4. Maps showing locations of bathymetric- and topographic-survey lines (blue and red lines, respectively), sound-velocity measurements derived from Conductivity Temperature Depth casts, and benchmarks used for geodetic control from 2015 surveys along Columbia River littoral cell; left and right panels show data coverage for northern and southern parts of study area, respectively. Abbreviations: CR, Columbia River; GH, Grays Harbor; km, kilometer(s). 


\section{A, Tide height}

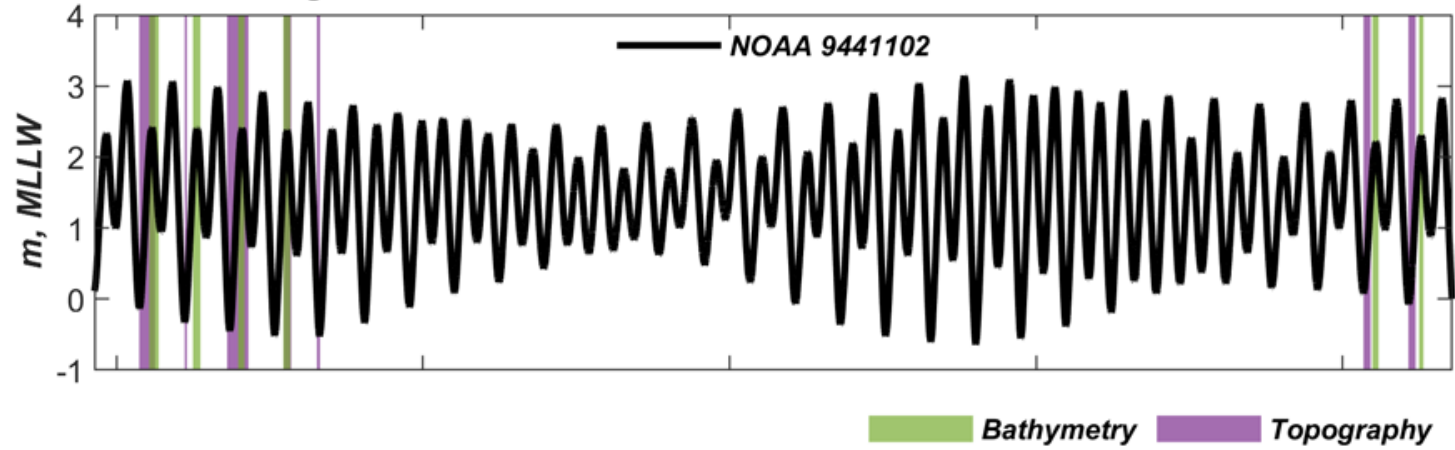

B, Significant wave height

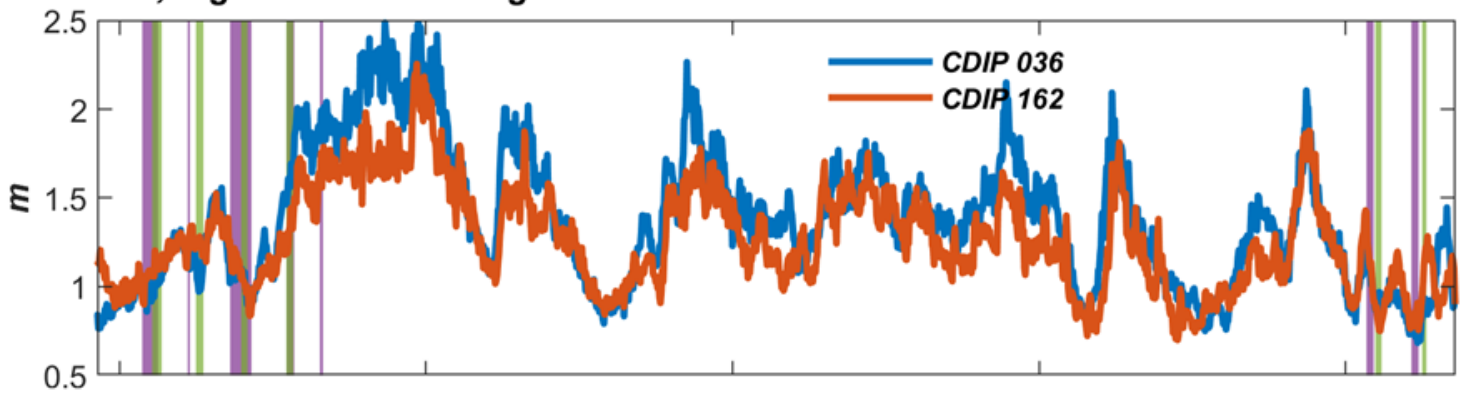

C, Peak wave period

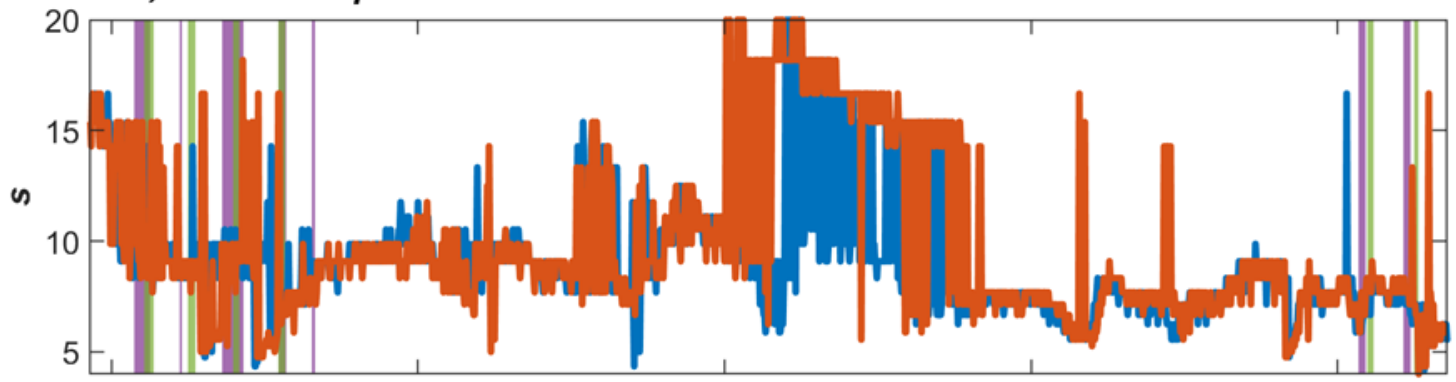

\section{$D$, Mean wave direction}

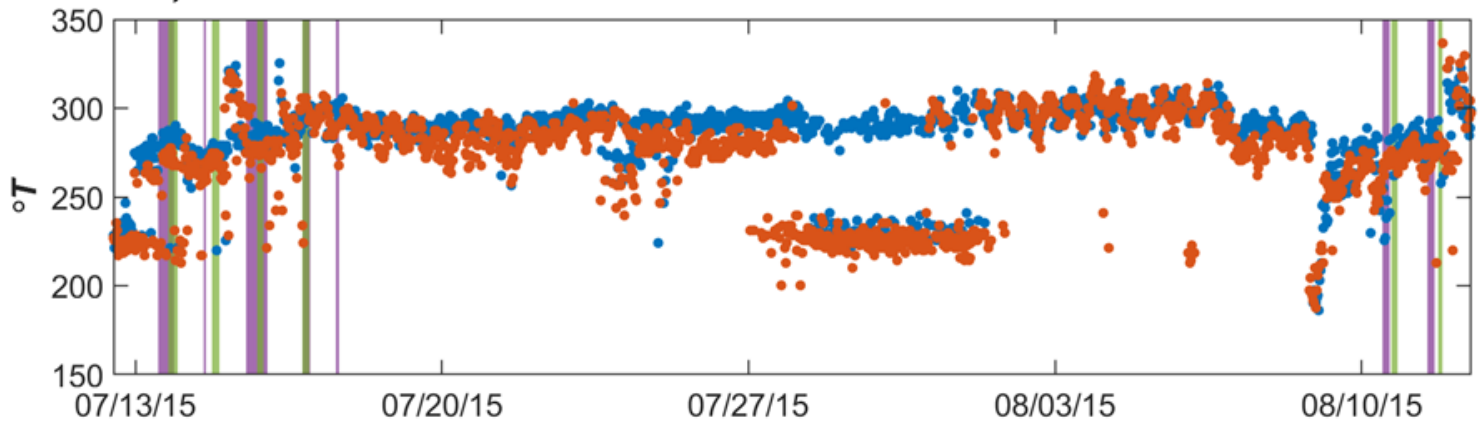

Figure A5. Time-series plots of $(A)$ water levels, $(B)$ wave heights, $(C)$ wave periods, and $(D)$ wave directions during 2015 bathymetric and topographic surveys of Columbia River littoral cell; green and purple shading shows timing of bathymetric- and topographic-data collections, respectively. Abbreviations: CDIP, Coastal Data Information Program; km, kilometer(s); m, meter(s); MLLW, mean lower low water; NOAA, National Oceanic and Atmospheric Administration; s, second(s); ${ }^{\circ} T$, degree(s) true north. 
A

$-124.2^{\circ}-124.0^{\circ}$

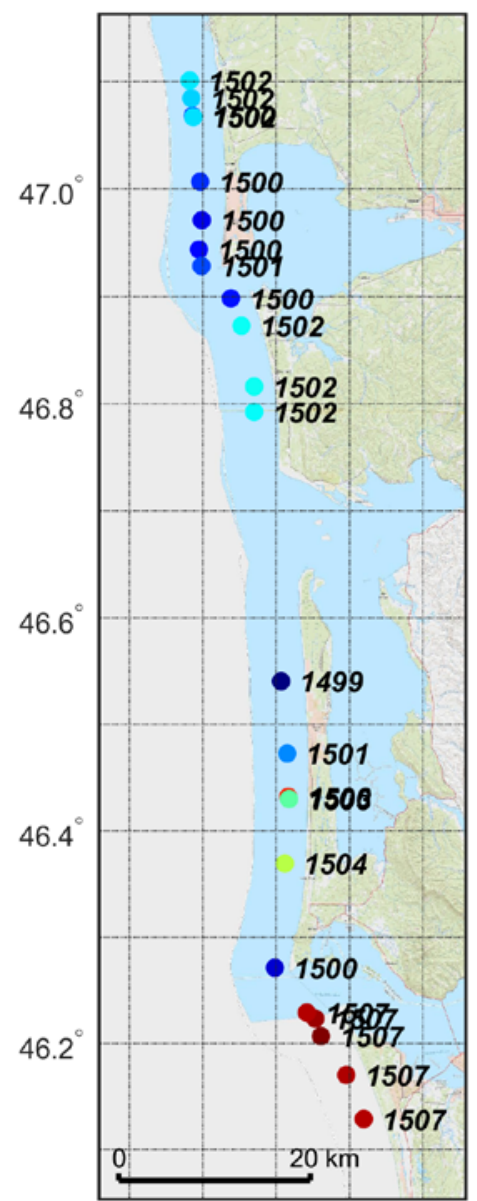

B Temperature $(\operatorname{deg} C)$

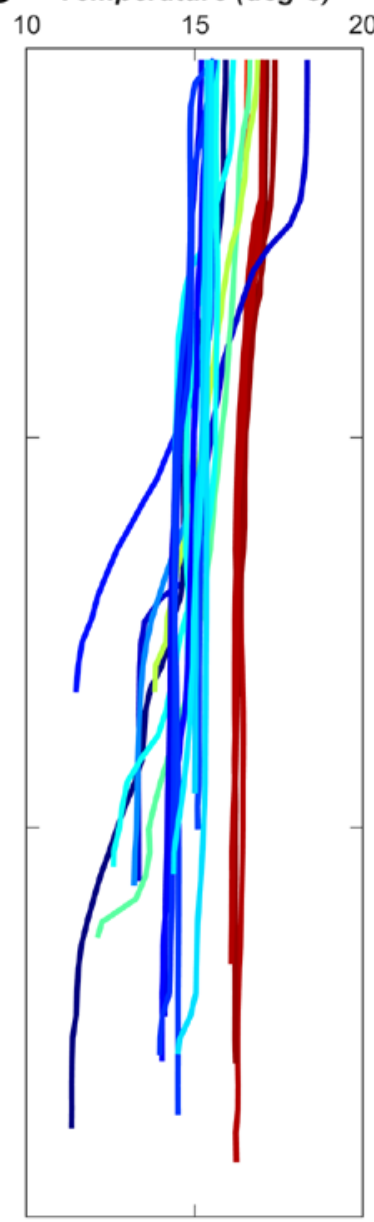

C

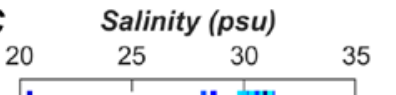

D Sound Velocity $(\mathrm{m} / \mathrm{s})$

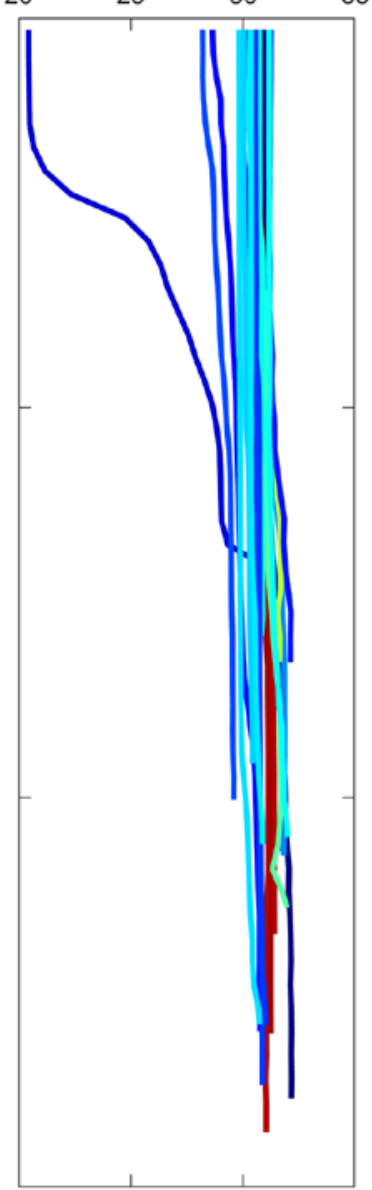

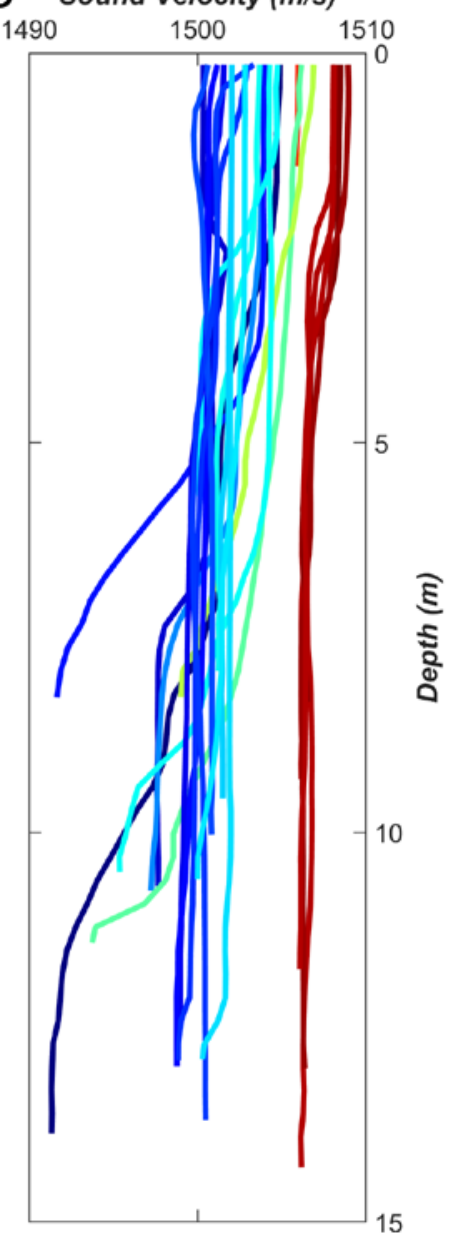

Figure A6. A, Map showing locations (colored dots) of Conductivity Temperature Depth casts collected during 2015 bathymetric surveys; numbers represent depth-averaged sound velocities. Depth profiles of water-column properties were measured during each cast, including $(B)$ temperature, $(C)$ salinity, and $(D)$ sound velocity. Abbreviations: deg $C$, degrees Celsius; km, kilometer(s); m, meter(s); psu, practical salinity unit(s); s, second. 

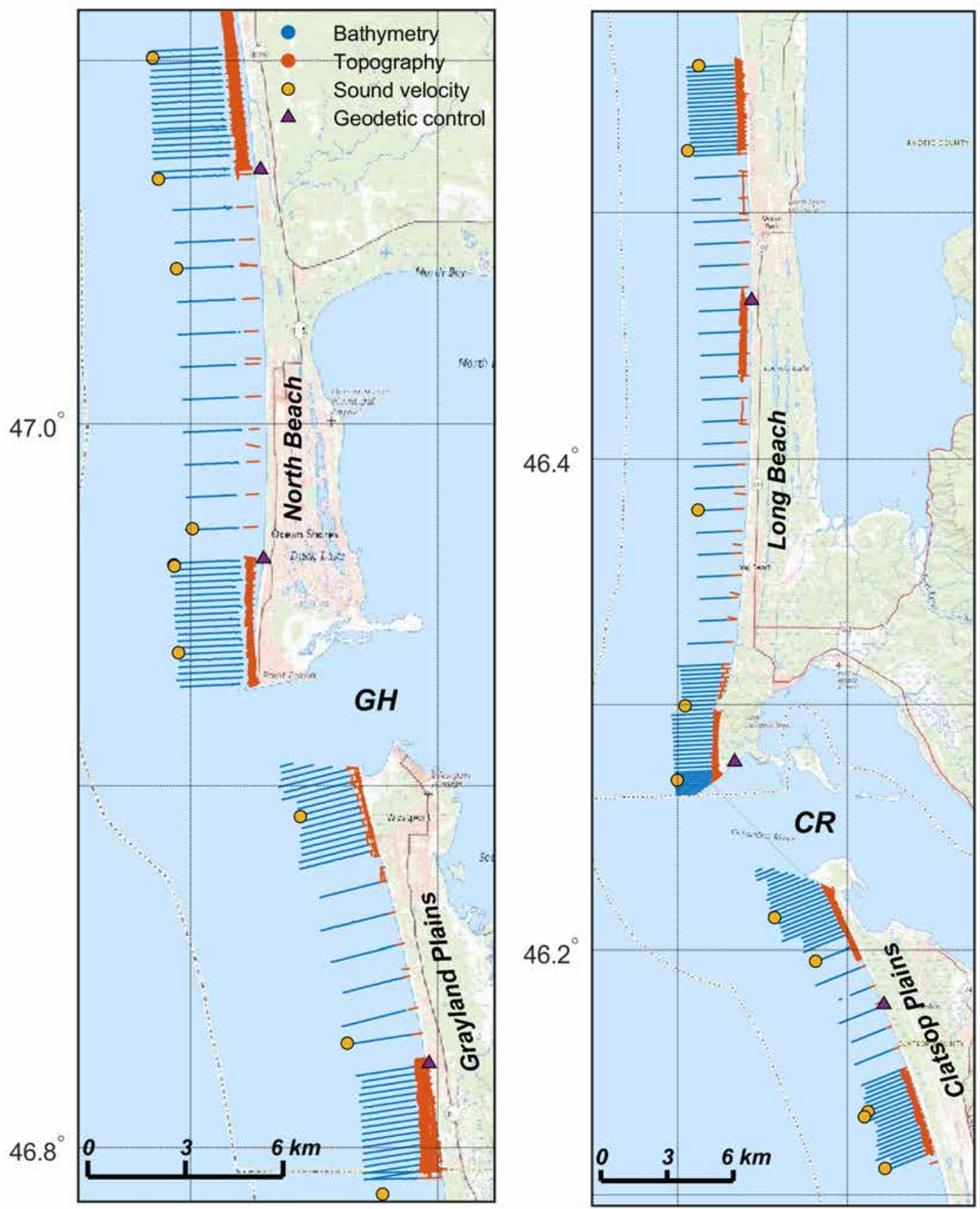

Figure A7. Maps showing locations of bathymetric- and topographic-survey lines (blue and red lines, respectively), sound-velocity measurements derived from Conductivity Temperature Depth casts, and benchmarks used for geodetic control from 2016 surveys along Columbia River littoral cell; left and right panels show data coverage for northern and southern parts of study area, respectively. Abbreviations: CR, Columbia River; GH, Grays Harbor; km, kilometer(s). 


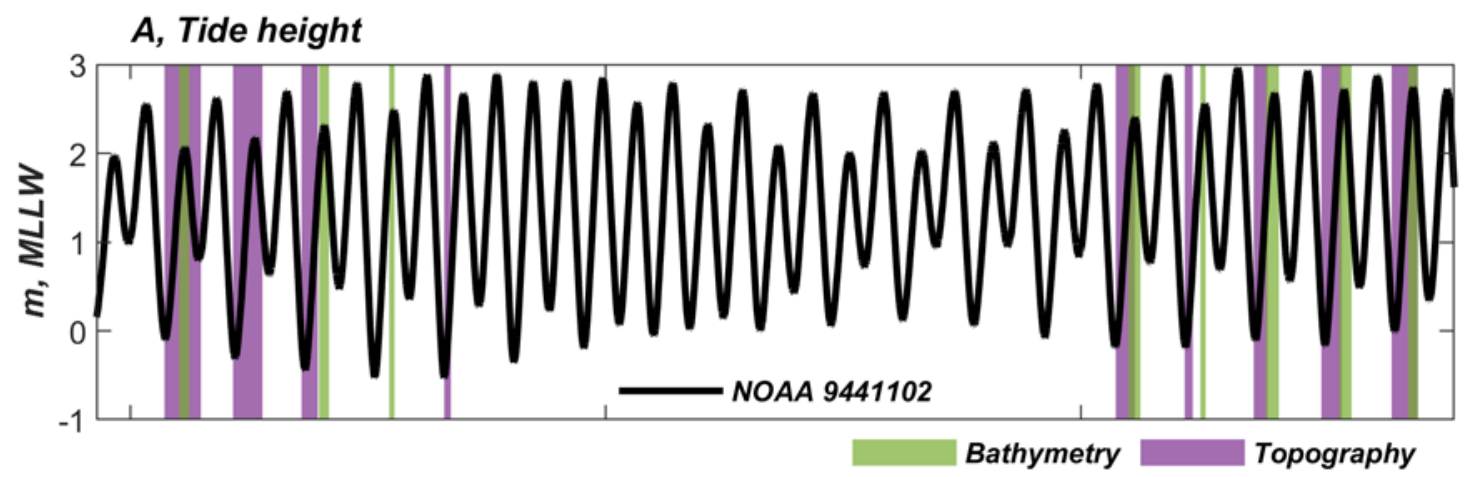

\section{B, Significant wave height}

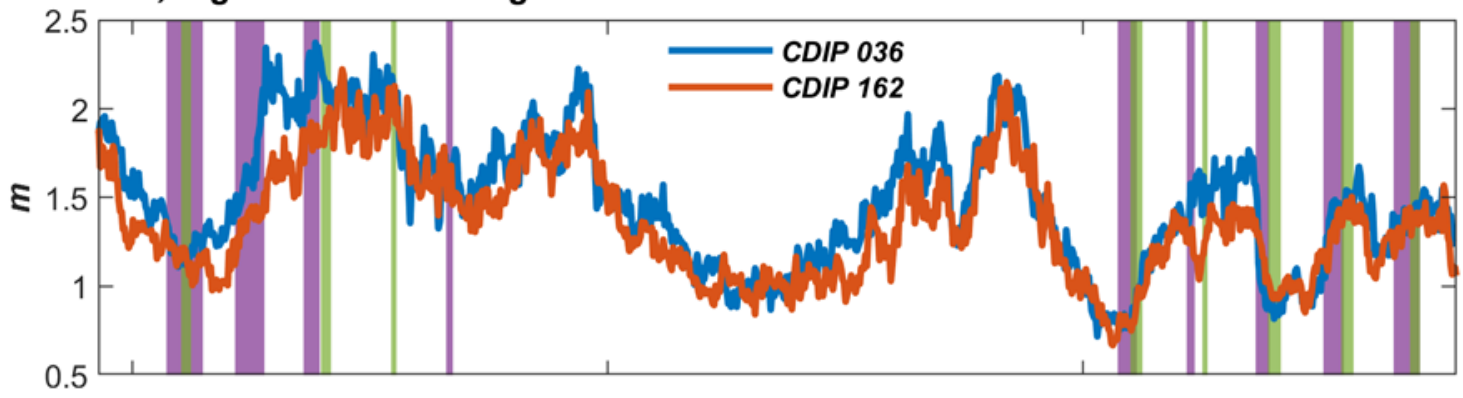

C, Peak wave period
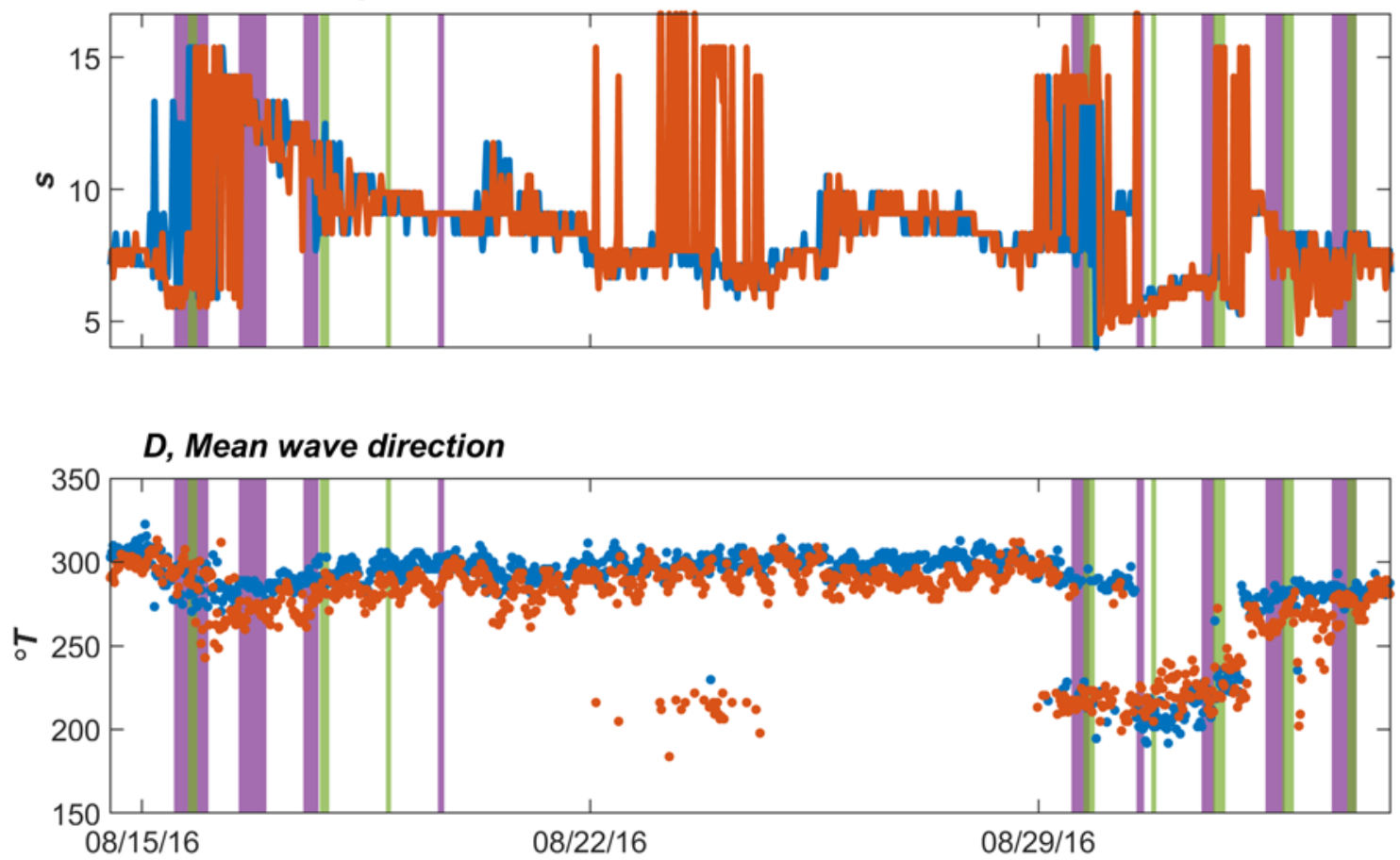

Figure A8. Time-series plots of $(A)$ water levels, $(B)$ wave heights, $(C)$ wave periods, and $(D)$ wave directions during 2016 bathymetric and topographic surveys of Columbia River littoral cell; green and purple shading shows timing of bathymetric and topographic-data collections, respectively. Abbreviations: CDIP, Coastal Data Information Program; km, kilometer(s); m, meter(s); MLLW, mean lower low water; NOAA, National Oceanic and Atmospheric Administration; s, second(s); ${ }^{\circ} \mathrm{T}$, degree(s) true north. 
A

$-124.2^{\circ}-124.0^{\circ}$

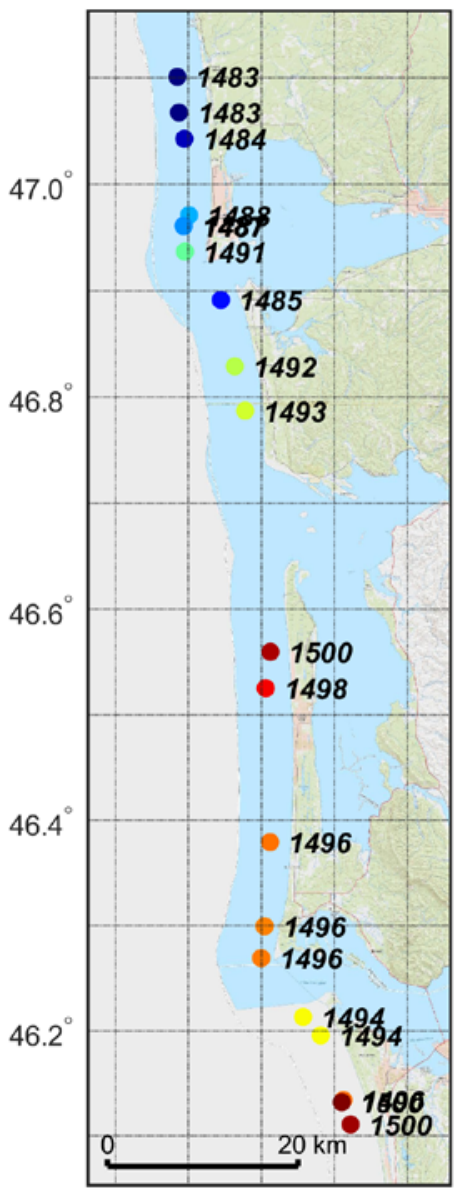

B

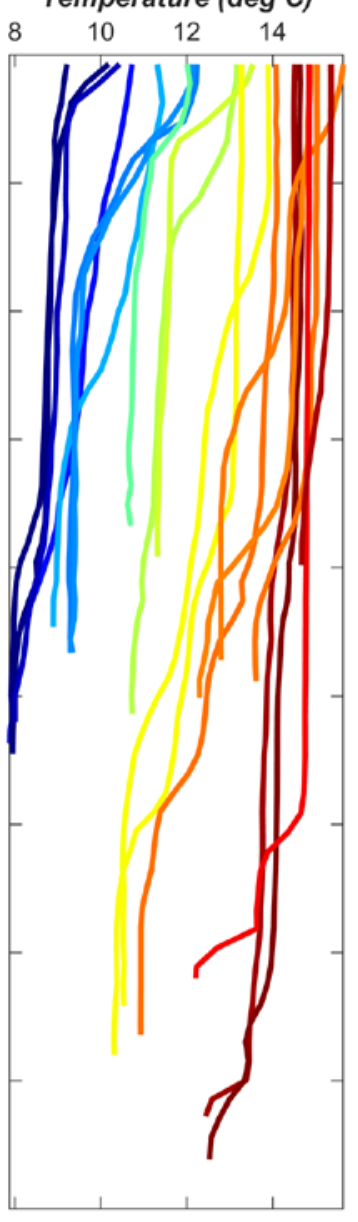

C

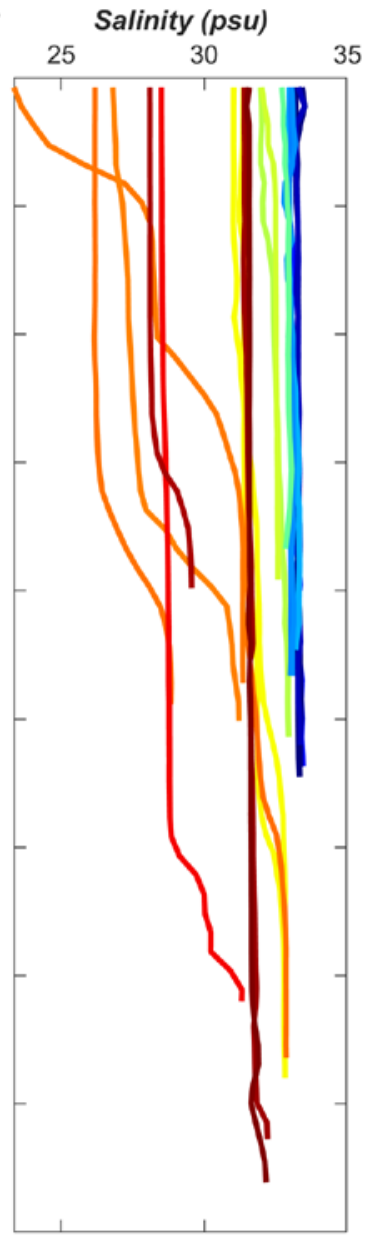

D Sound Velocity $(\mathrm{m} / \mathrm{s})$

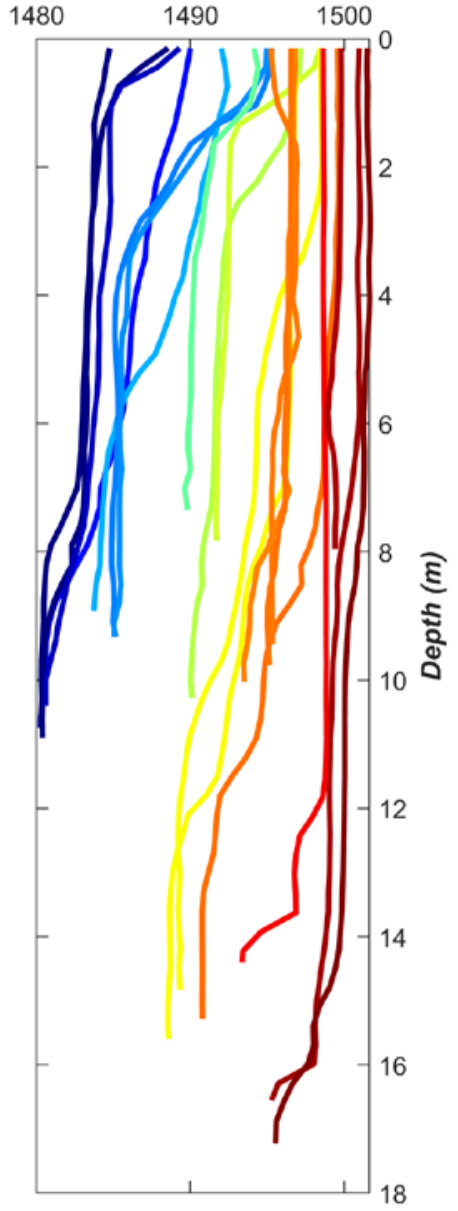

Figure A9. A, Map showing locations (colored dots) of Conductivity Temperature Depth casts collected during 2016 bathymetric surveys; numbers represent depth-averaged sound velocities. Depth profiles of water-column properties were measured during each cast, including $(B)$ temperature, $(C)$ salinity, and $(D)$ sound velocity. Abbreviations: $\operatorname{deg} C$, degrees Celsius; km, kilometer(s); m, meter(s); psu, practical salinity unit(s); s, second. 
$-124.2^{\circ}$

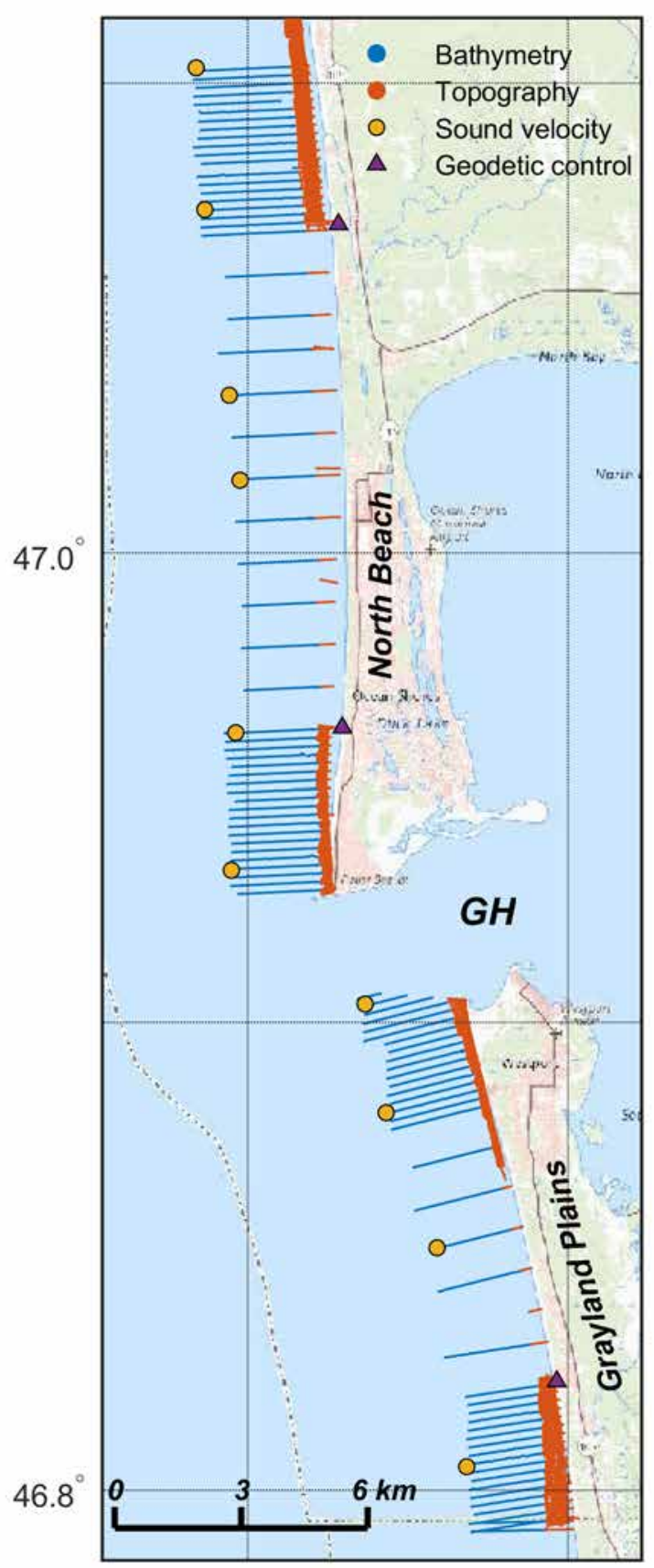

46.4

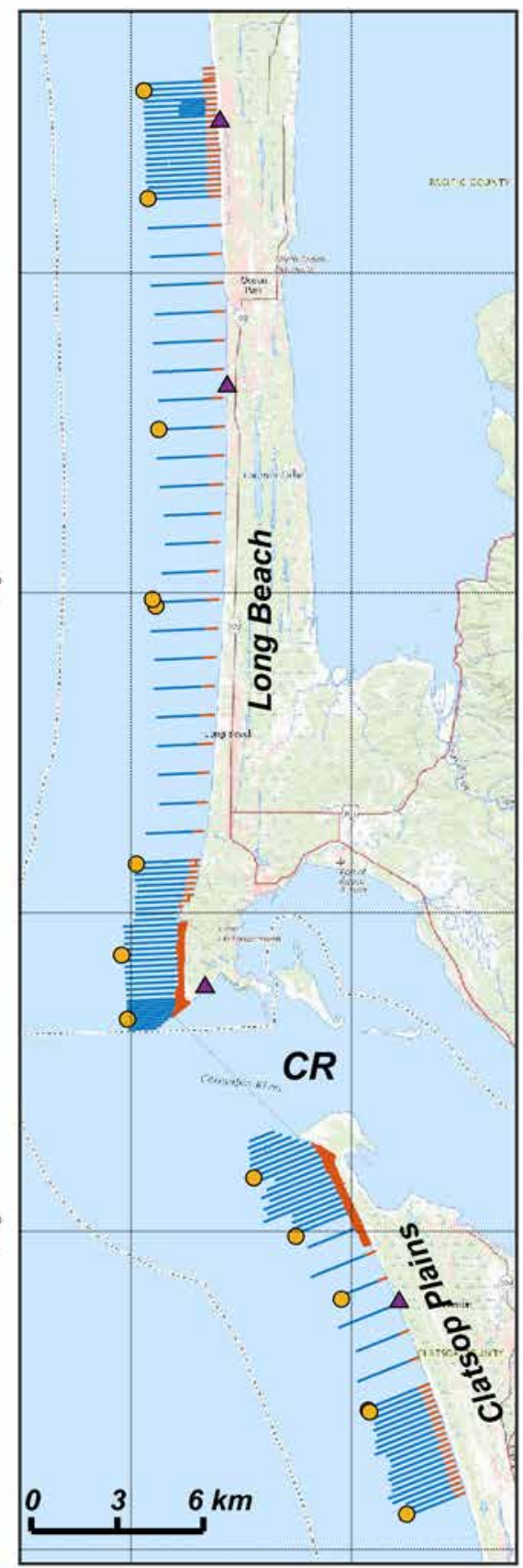

Figure A10. Maps showing locations of bathymetric- and topographic-survey lines (blue and red lines, respectively), sound-velocity measurements derived from Conductivity Temperature Depth casts, and benchmarks used for geodetic control from 2017 surveys along Columbia River littoral cell; left and right panels show data coverage for northern and southern parts of study area, respectively. Abbreviations: CR, Columbia River; GH, Grays Harbor; km, kilometer(s). 

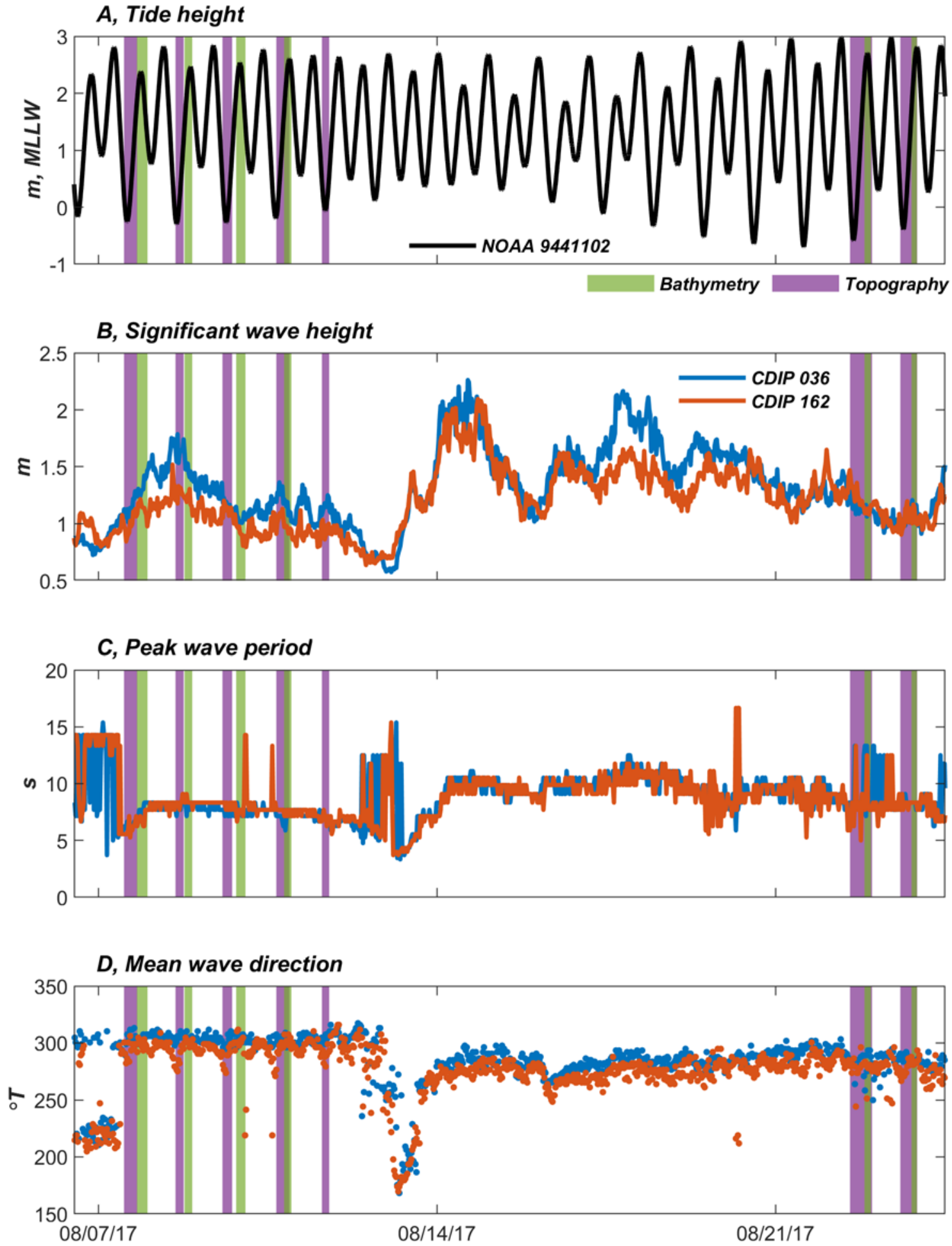

Figure A11. Time-series plots of $(A)$ water levels, $(B)$ wave heights, $(C)$ wave periods, and $(D)$ wave directions during 2017 bathymetric and topographic surveys of Columbia River littoral cell; green and purple shading shows timing of bathymetric- and topographic-data collections, respectively. Abbreviations: CDIP, Coastal Data Information Program; km, kilometer(s); m, meter(s); MLLW, mean lower low water; NOAA, National Oceanic and Atmospheric Administration; s, second(s); ${ }^{\circ} T$, degree(s) true north. 

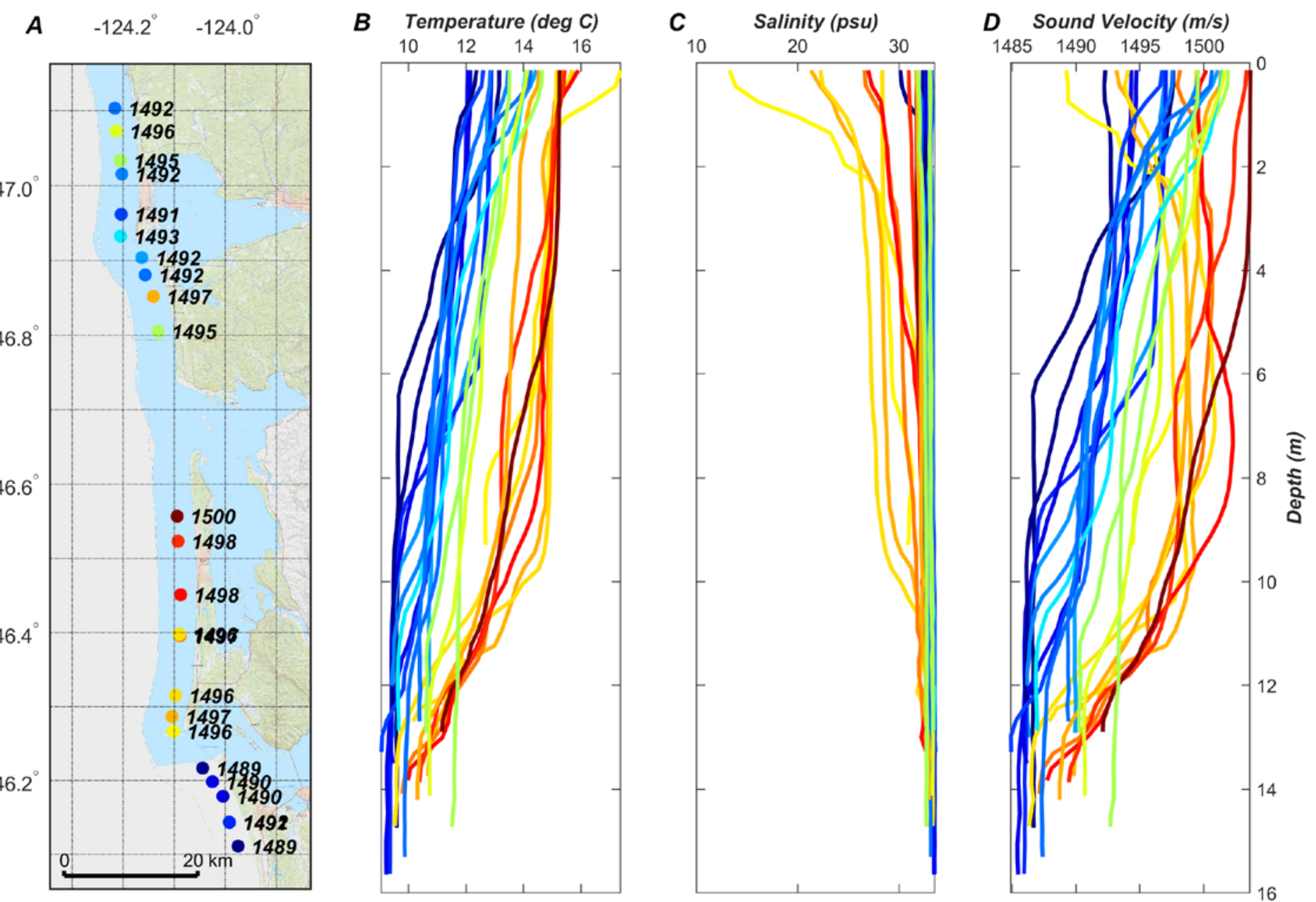

Figure A12. A, Map showing locations (colored dots) of Conductivity Temperature Depth casts collected during 2017 bathymetric surveys; numbers represent depth-averaged sound velocities. Depth profiles of water-column properties were measured during each cast, including $(B)$ temperature, $(C)$ salinity, and $(D)$ sound velocity. Abbreviations: deg $C$, degrees Celsius; km, kilometer(s); m, meter(s); psu, practical salinity unit(s); s, second. 

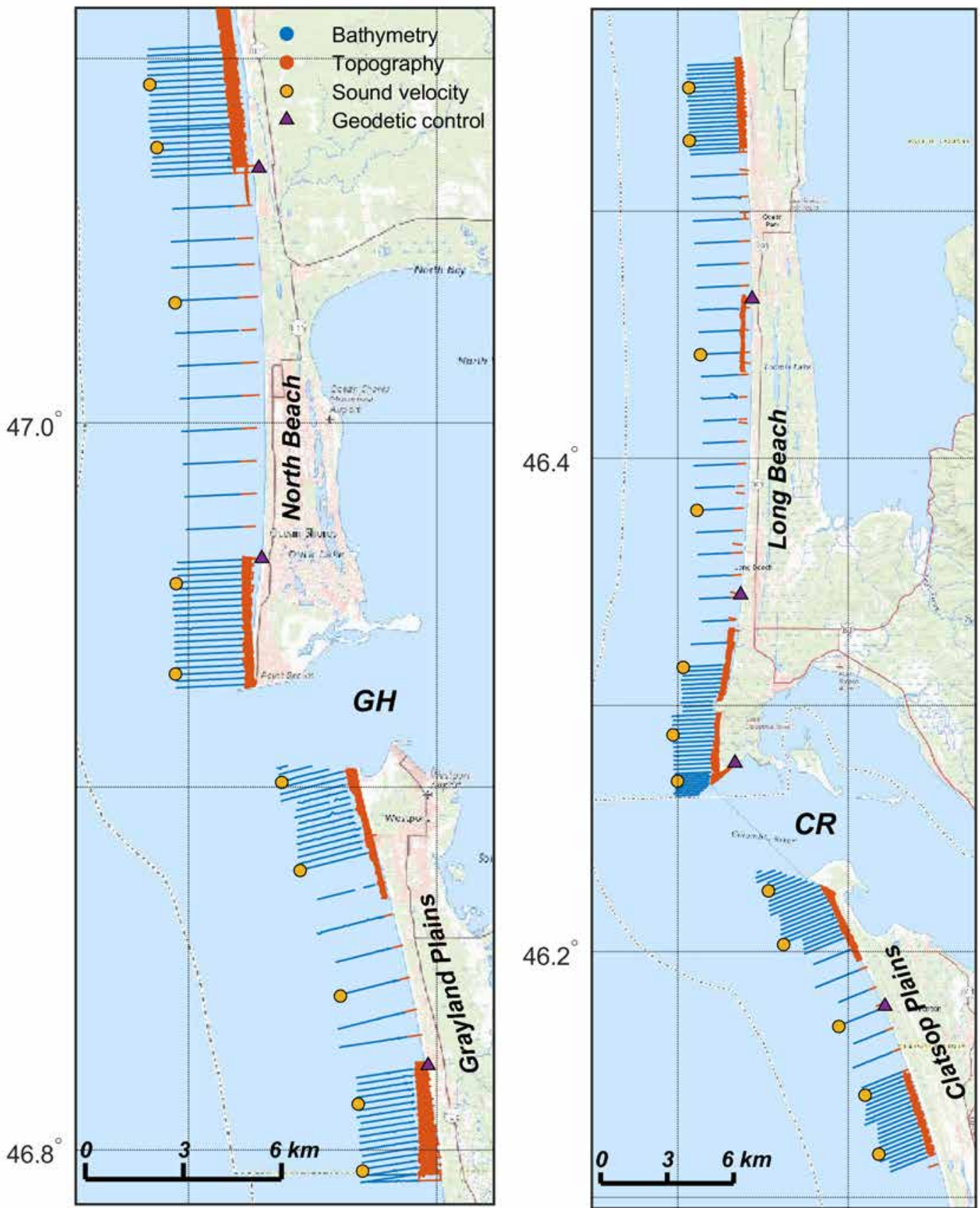

Figure A13. Maps showing locations of bathymetric- and topographic-survey lines (blue and red lines, respectively), sound-velocity measurements derived from Conductivity Temperature Depth casts, and benchmarks used for geodetic control from 2018 surveys along Columbia River littoral cell; left and right panels show data coverage for northern and southern parts of study area, respectively. Abbreviations: CR, Columbia River; GH, Grays Harbor; km, kilometer(s). 

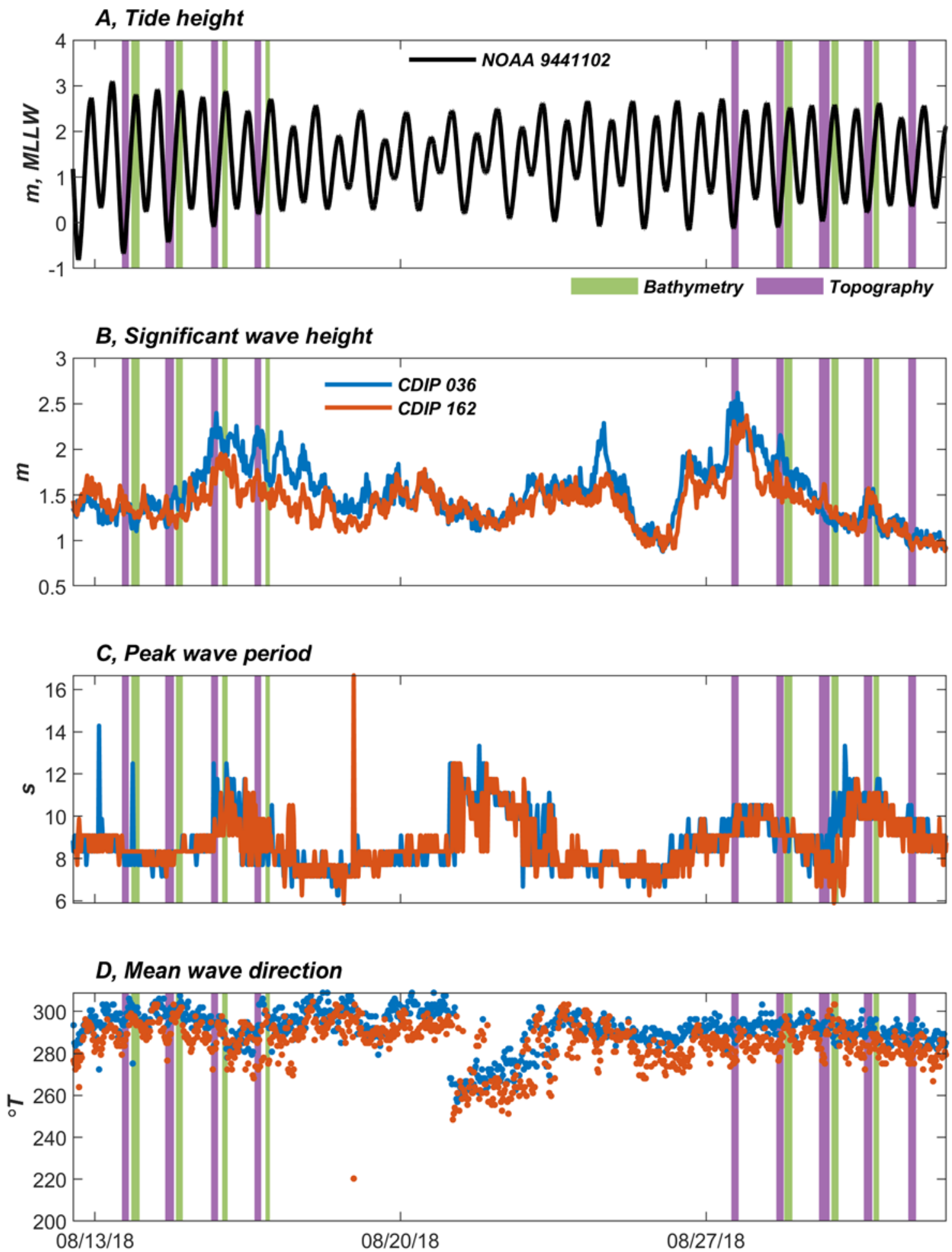

Figure A14. Time-series plots of $(A)$ water levels, $(B)$ wave heights, $(C)$ wave periods, and $(D)$ wave directions during 2018 bathymetric and topographic surveys of Columbia River littoral cell; green and purple shading shows timing of bathymetric and topographic-data collections, respectively. Abbreviations: CDIP, Coastal Data Information Program; km, kilometer(s); m, meter(s); MLLW, mean lower low water; NOAA, National Oceanic and Atmospheric Administration; s, second(s); ${ }^{\circ} T$, degree(s) true north. 
$\boldsymbol{A}$

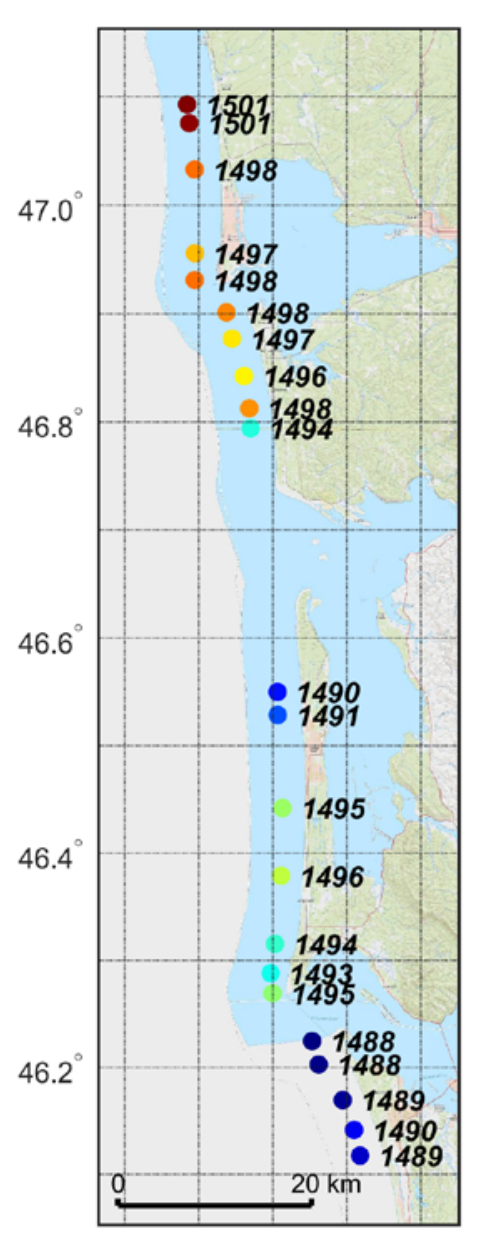

B Temperature $(\operatorname{deg} C)$

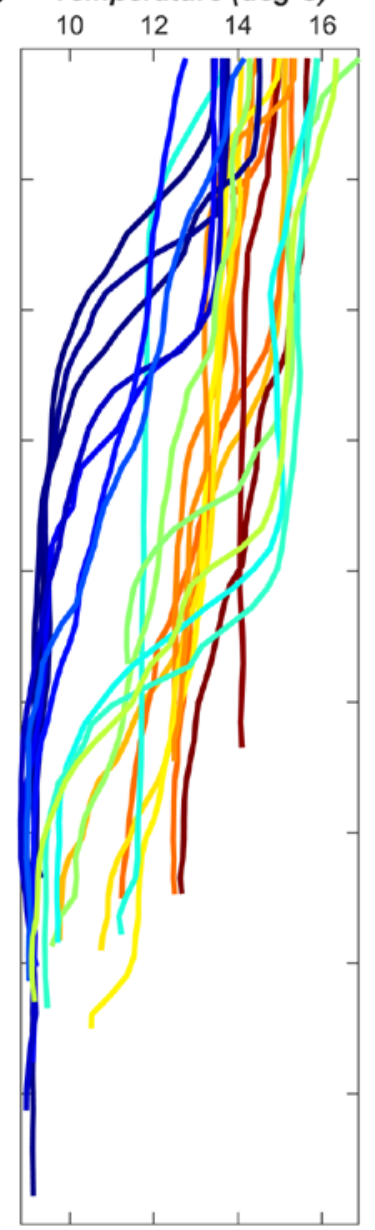

C

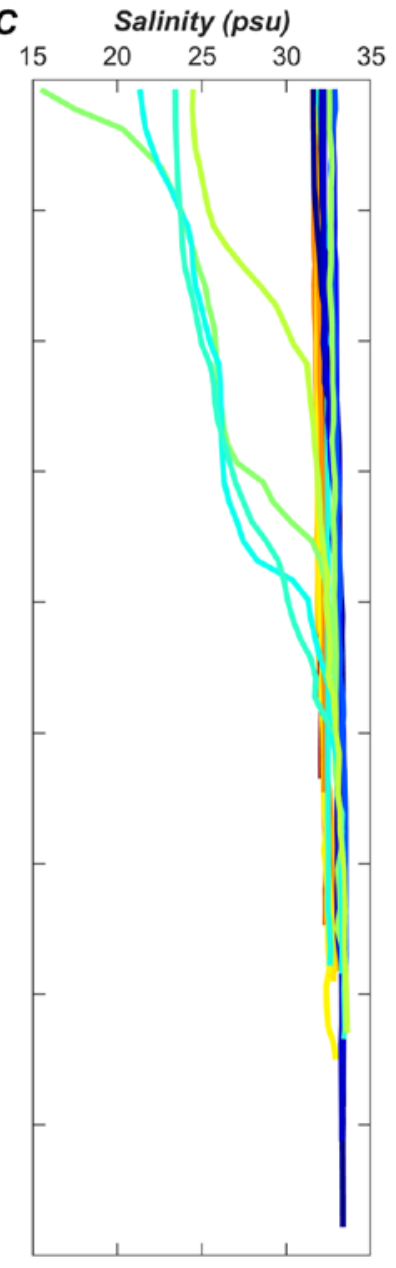

D Sound Velocity $(\mathrm{m} / \mathrm{s})$

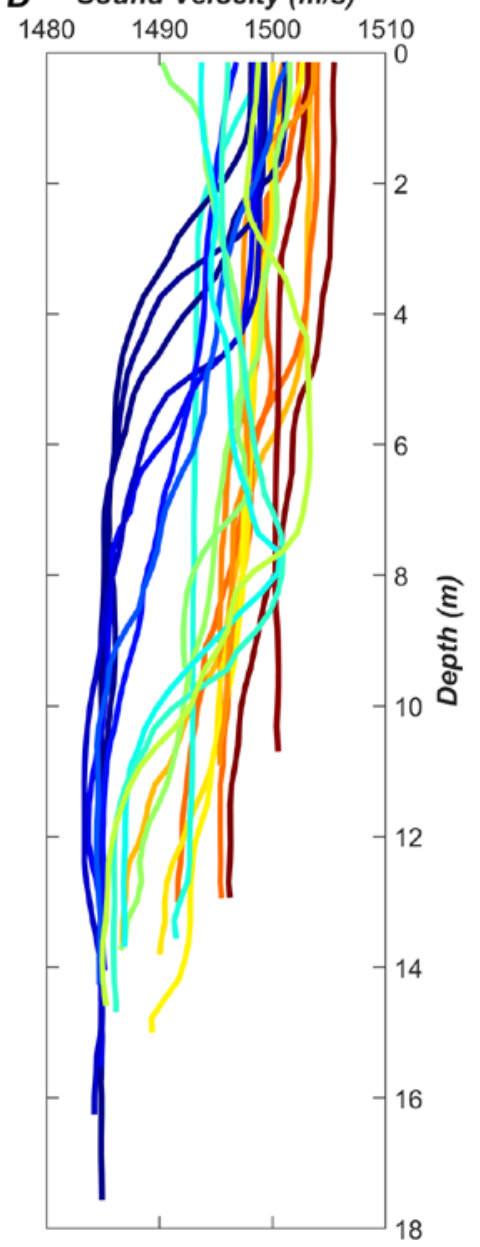

Figure A15. A, Map showing locations (colored dots) of Conductivity Temperature Depth casts collected during 2018 bathymetric surveys; numbers represent depth-averaged sound velocities. Depth profiles of water-column properties were measured during each cast, including $(B)$ temperature, $(C)$ salinity, and $(D)$ sound velocity. Abbreviations: deg $C$, degrees Celsius; $\mathrm{km}$, kilometer $(\mathrm{s}) ; \mathrm{m}$, meter(s); psu, practical salinity unit(s); s, second. 
$-124.2^{\circ}$

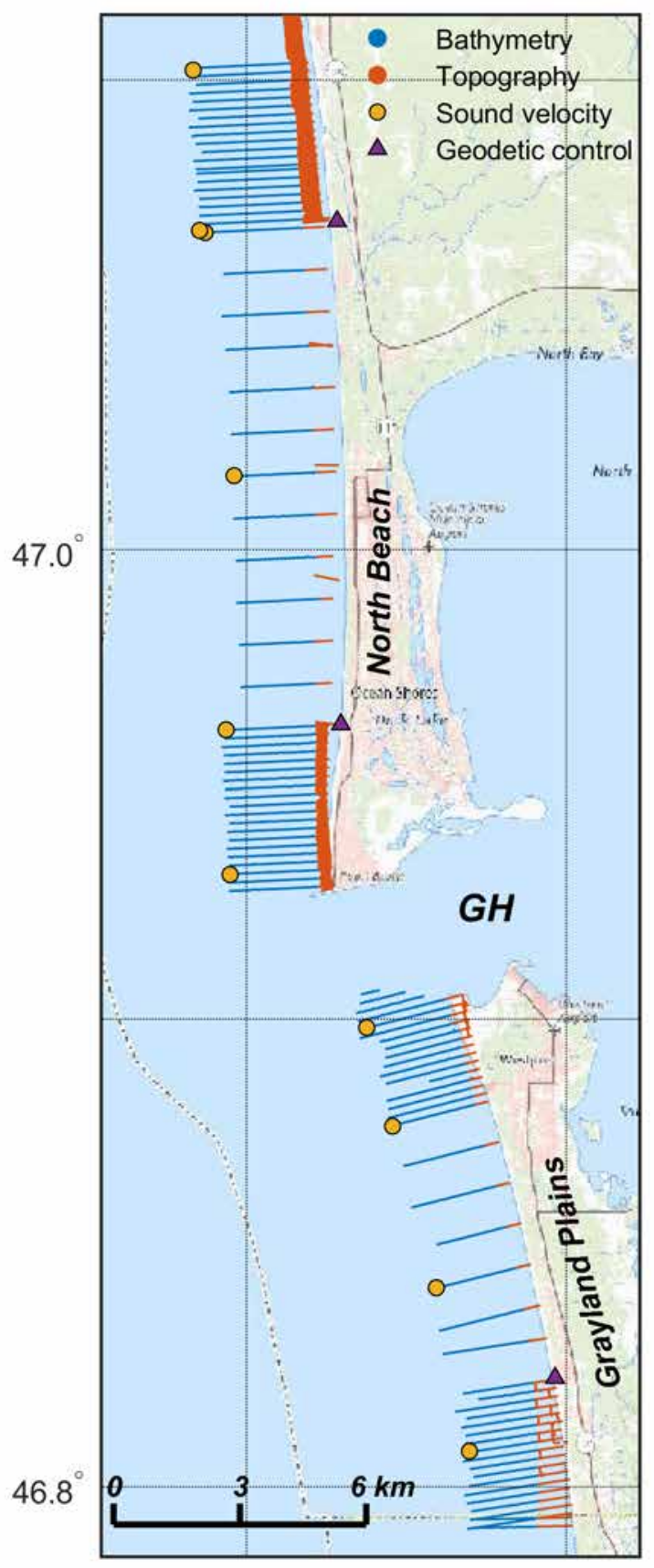

$-124.0^{\circ}$

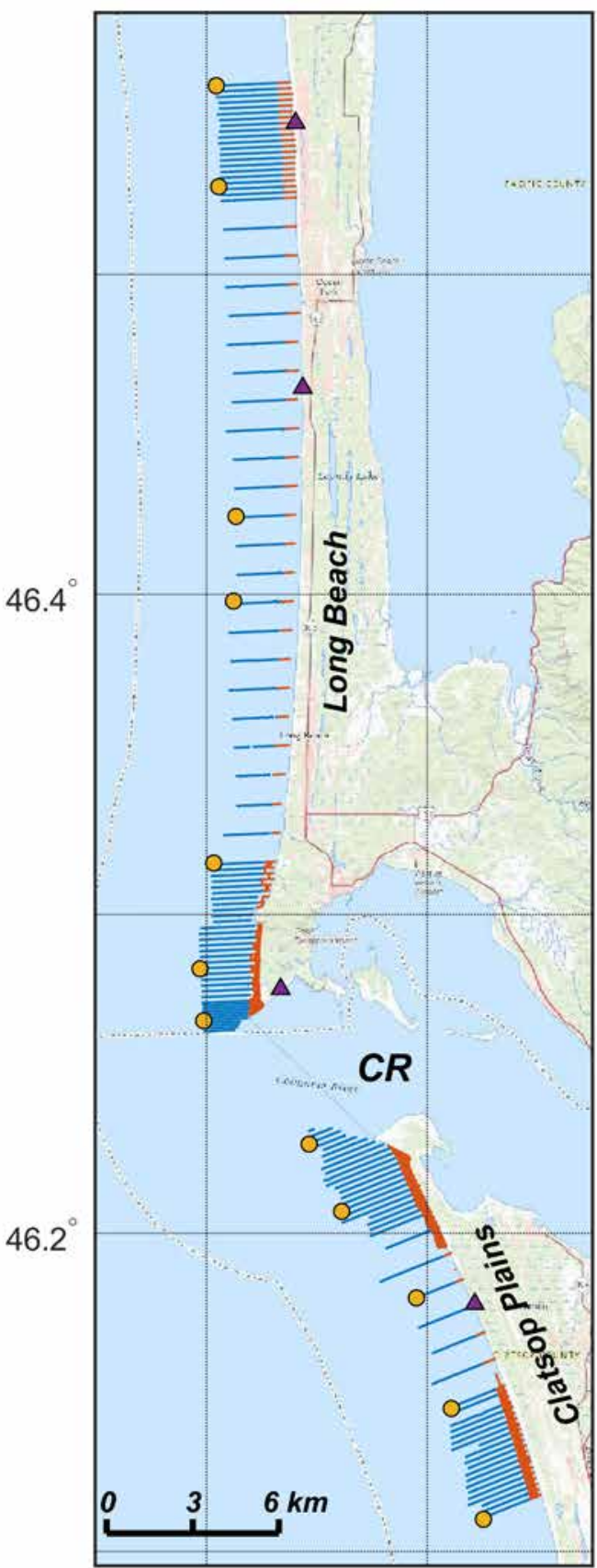

Figure A16. Maps showing locations of bathymetric- and topographic-survey lines (blue and red lines, respectively), sound-velocity measurements derived from Conductivity Temperature Depth casts, and benchmarks used for geodetic control from 2019 surveys along Columbia River littoral cell; left and right panels show data coverage for northern and southern parts of study area, respectively. Abbreviations: CR, Columbia River; GH, Grays Harbor; km, kilometer(s). 

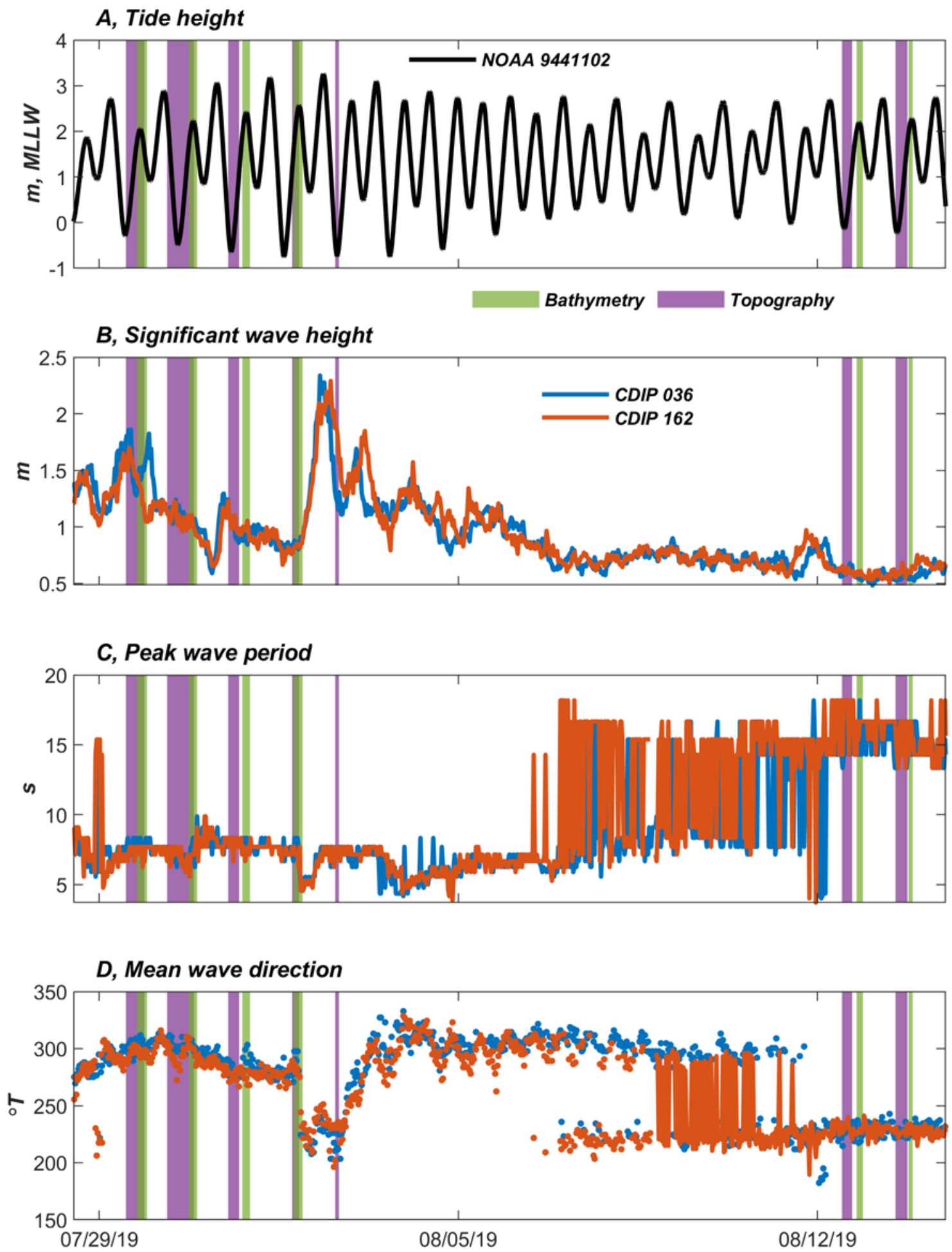

Figure A17. Time-series plots of $(A)$ water levels, $(B)$ wave heights, $(C)$ wave periods, and $(D)$ wave directions during 2019 bathymetric and topographic surveys of Columbia River littoral cell; green and purple shading shows timing of bathymetric-and topographic-data collections, respectively. Abbreviations: CDIP, Coastal Data Information Program; km, kilometer(s); m, meter(s); MLLW, mean lower low water; NOAA, National Oceanic and Atmospheric Administration; s, second(s); ${ }^{\circ} T$, degree(s) true north. 
$\boldsymbol{A} \quad-124.2^{\circ}-124.0^{\circ}$

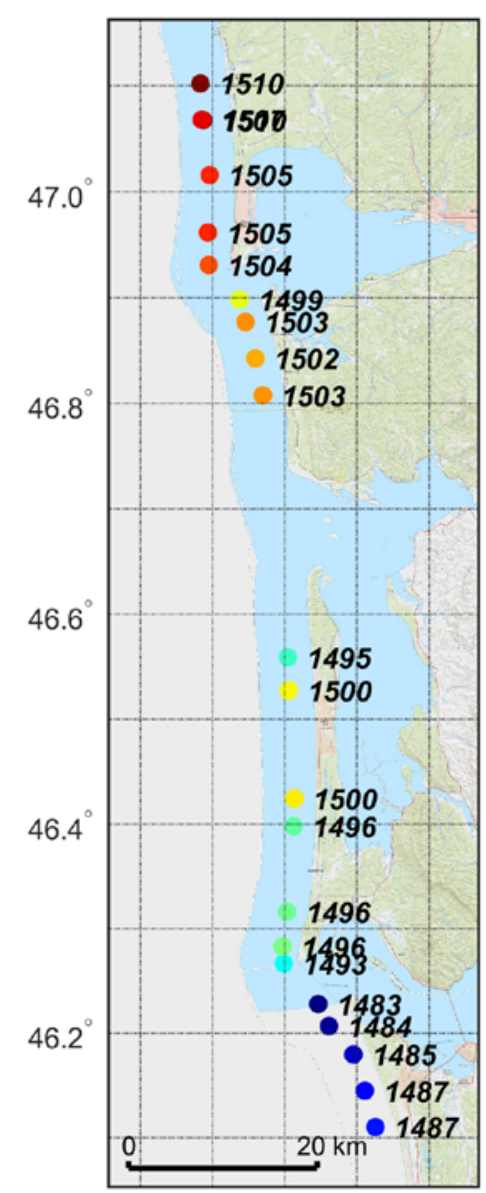

B

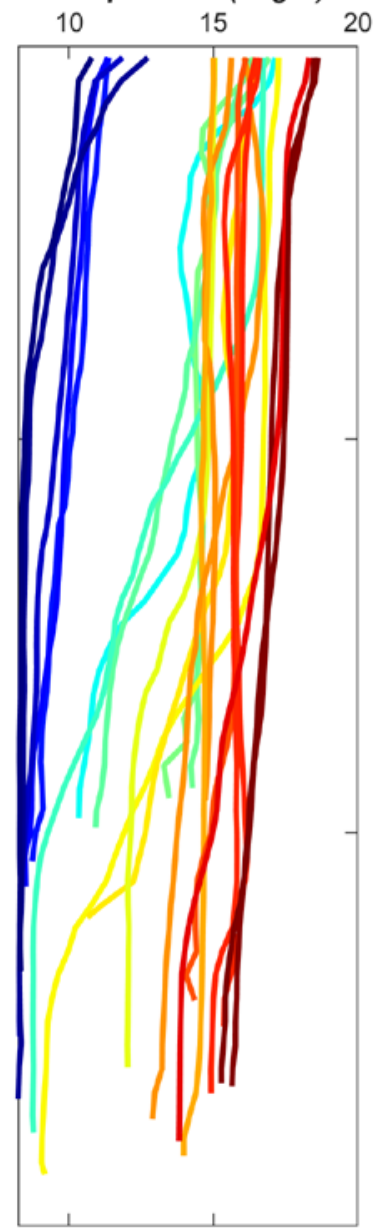

C Salinity (psu)

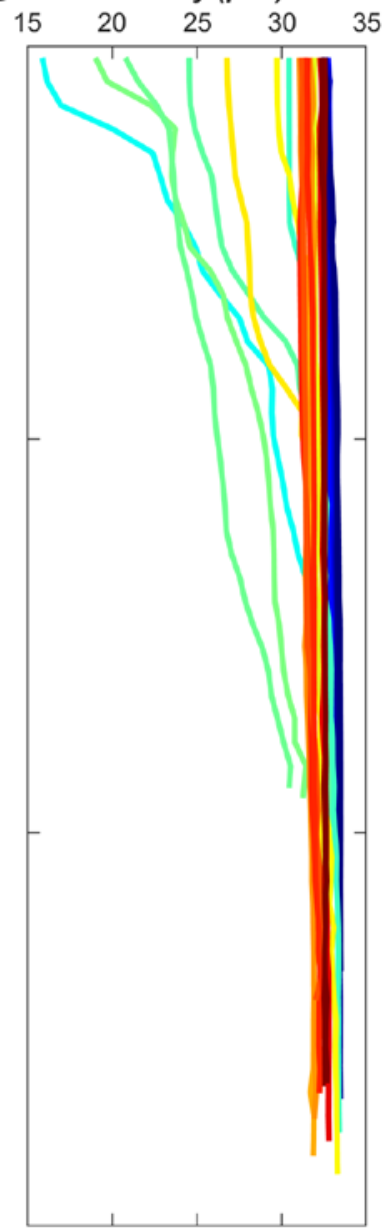

D Sound Velocity $(\mathrm{m} / \mathrm{s})$

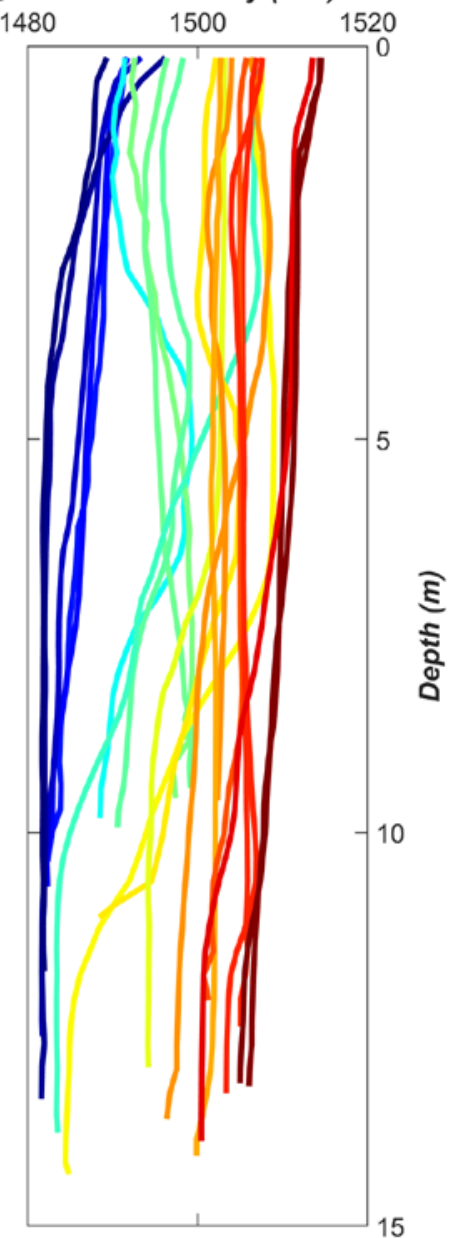

Figure A18. A, Map showing locations (colored dots) of Conductivity Temperature Depth casts collected during 2019 bathymetric surveys; numbers represent depth-averaged sound velocities. Depth profiles of water-column properties were measured during each cast, including $(B)$ temperature, $(C)$ salinity, and $(D)$ sound velocity. Abbreviations: deg $C$, degrees Celsius; km, kilometer(s); m, meter(s); psu, practical salinity unit(s); s, second. 


\section{Appendix 2. Wave Heights, Mean Sediment-Transport Fluxes, and Sediment- Transport Pathways for Schematized Wave-Climate Simulations}

In this appendix, we provide maps that show simulated wave heights, mean sediment-transport fluxes, and visualizations of sediment-transport pathways for 19 wave classes in schematized wave climates and for both high- and low-discharge scenarios (see table 5 for wave-parameter specifications and probabilities of occurrence for all wave classes).

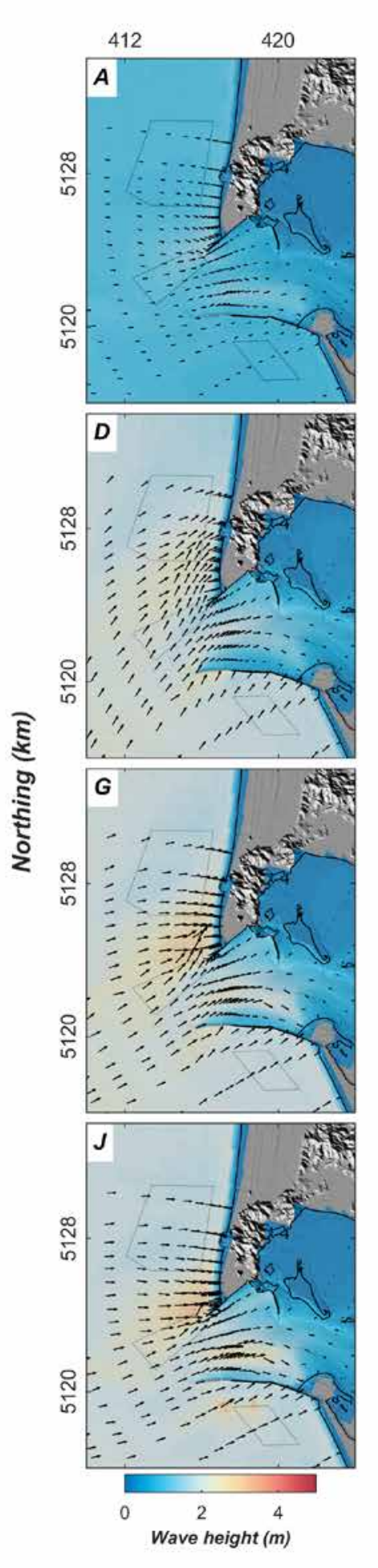

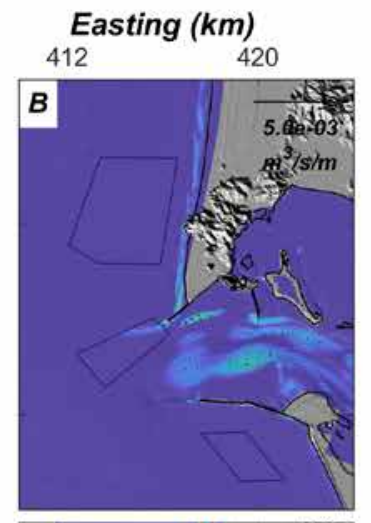
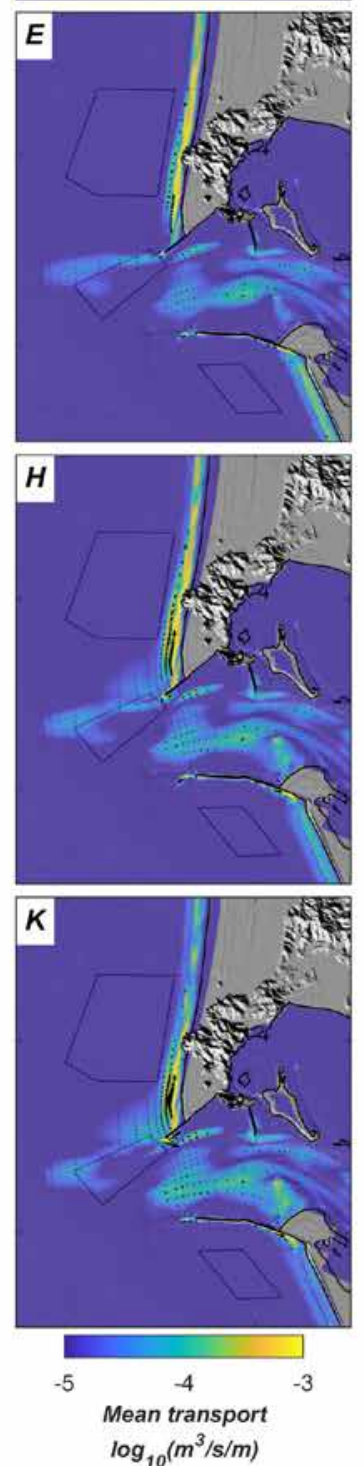
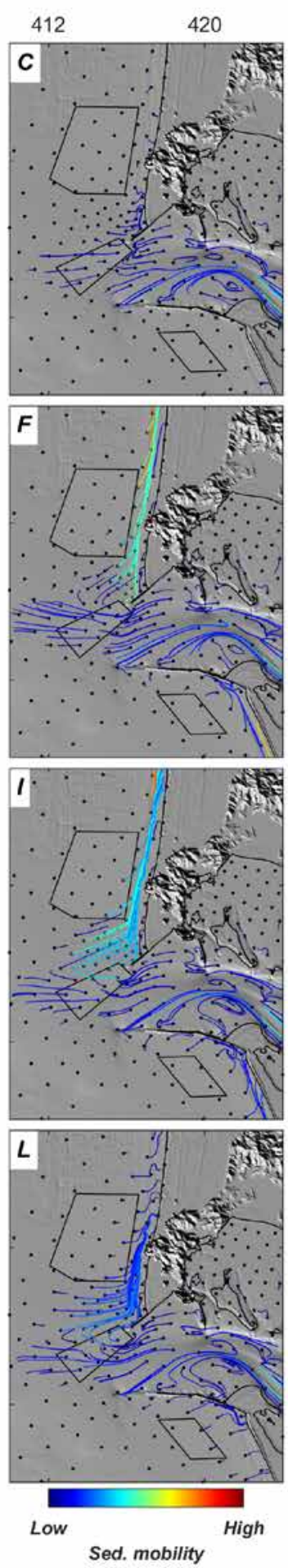

Figure B1. Maps showing modeled wave parameters for wave classes $1(A-C), 2(D-F), 3(G-I)$, and $4(J-L)$ during low-river-discharge scenarios (wave classes 1-4 depict winter conditions; see table 5 for wave parameters and probabilities of occurrence for each wave class). Black boxes show locations of dredge-placement sites. $A, D, G$, $J$ (left panels), significant wave heights; arrows show significant wave height magnitude and peak wave direction. $B, E, H, K$ (middle panels), mean total sediment transport; arrows show magnitude and direction of mean total sediment transport (lengths are scaled to length $\left[5 \times 10^{-3} \mathrm{~m}^{3} / \mathrm{s} / \mathrm{m}\right]$ of black arrow in upper right corner of B). $C, F, I, L$ (right panels), sedimenttransport pathways (colored lines); black dots indicate initial positions of modeled sediment sources; colors of sediment pathways indicate relative mobility of sources. Abbreviations: km, kilometer(s); m, meter(s); s, second. 

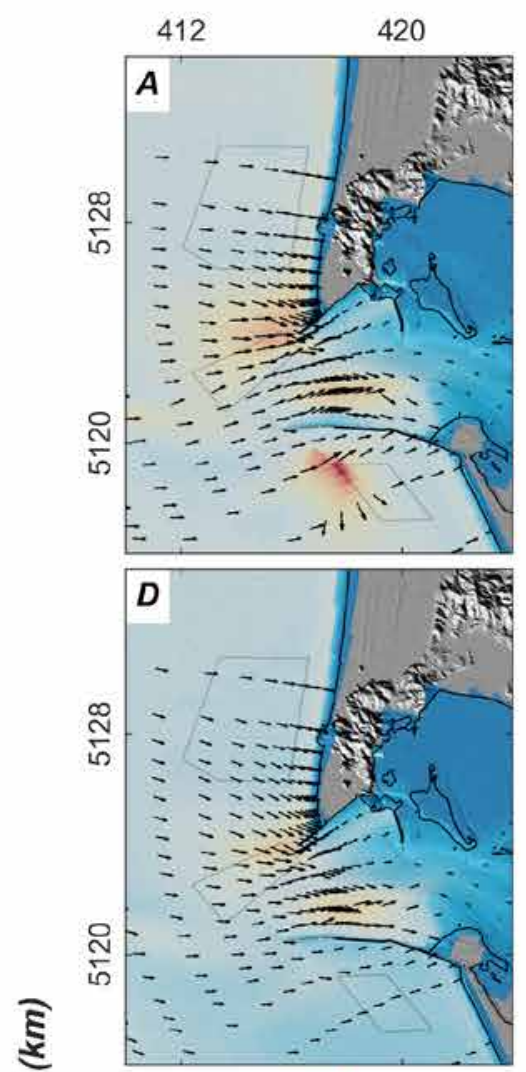

ํㅗㄹ
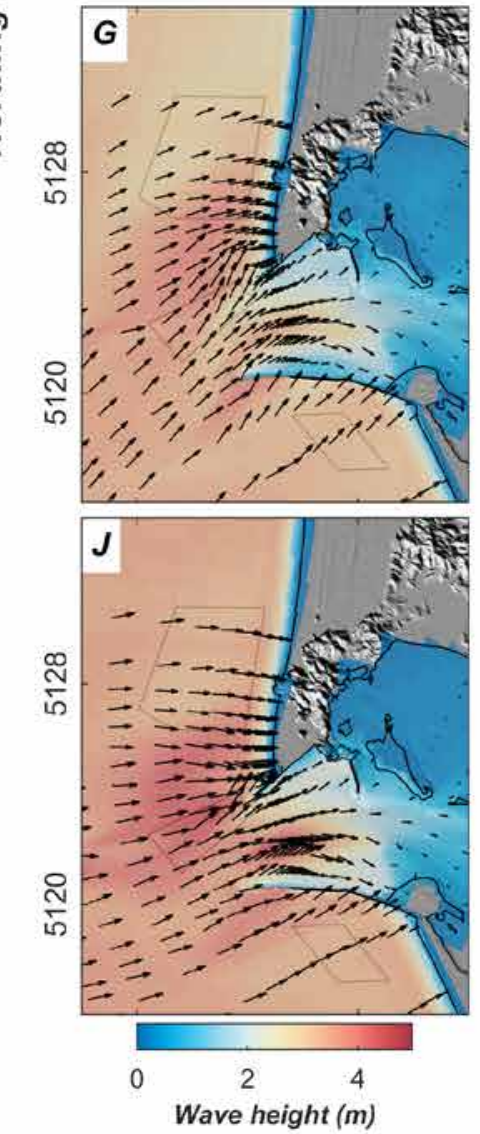

\section{Easting (km)}
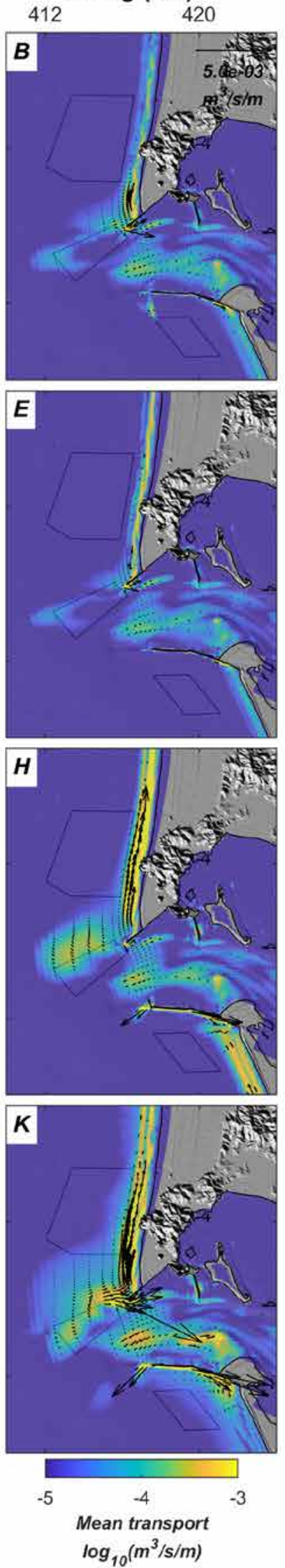
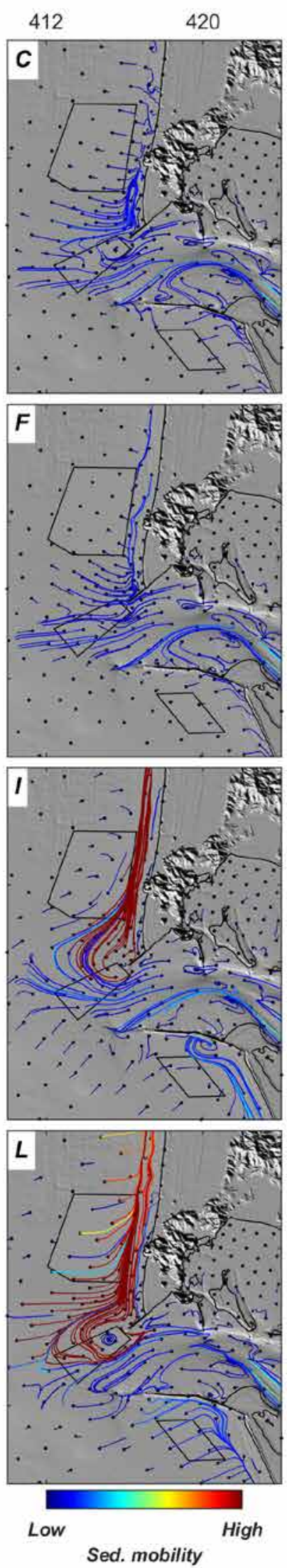

Figure B2. Maps showing modeled wave parameters for wave classes $5(A-C), 6(D-F)$, $7(G-I)$, and $8(J-L)$ during low-river-discharge scenarios (wave classes 5-8 depict winter conditions; see table 5 for wave parameters and probabilities of occurrence for each wave class). Black boxes show locations of dredge-placement sites. $A, D, G, J$ (left panels), signific ant wave heights; arrows show significant wave height magnitude and peak wave direction. $B, E, H, K$ (middle panels), mean total sediment transport; arrows show magnitude and direction of mean total sediment transport (lengths are scaled to length $\left[5 \times 10^{-3} \mathrm{~m}^{3} / \mathrm{s} / \mathrm{m}\right]$ of black arrow in upper right corner of $B$ ). $C, F, I, L$ (right panels), sediment-transport pathways (colored lines); black dots indicate initial positions of modeled sediment sources; colors of sediment pathways indicate relative mobility of sources. Abbreviations: km, kilometer(s); m, meter(s); s, second. 


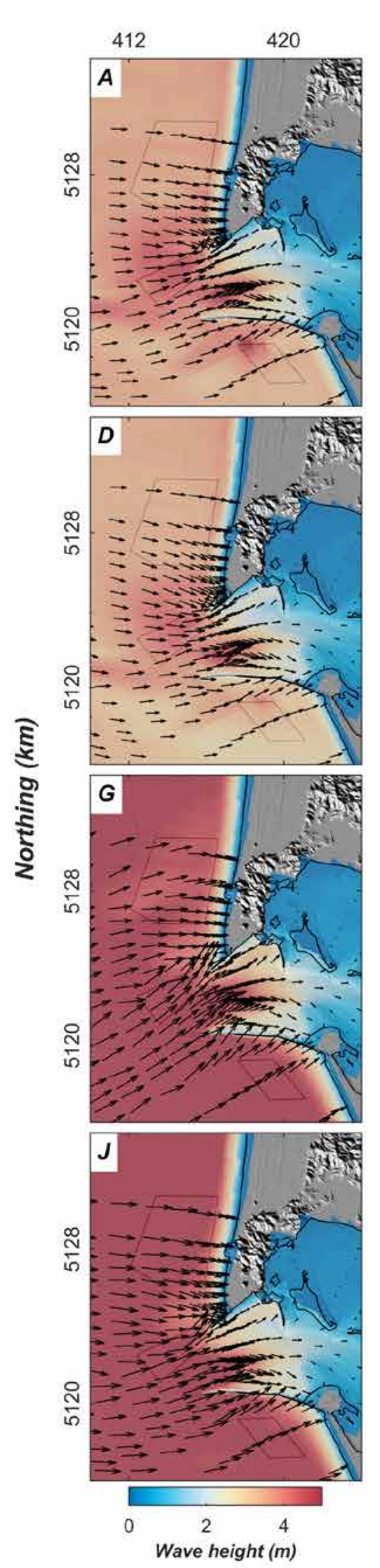

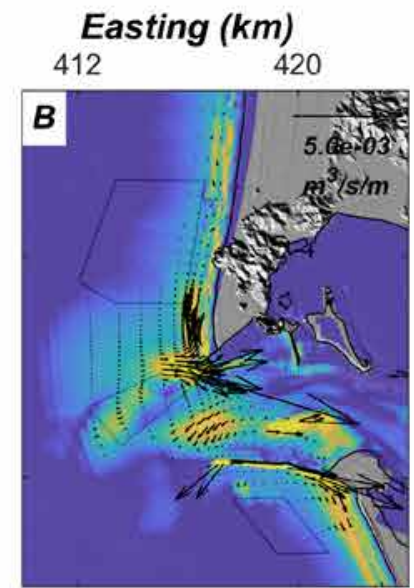
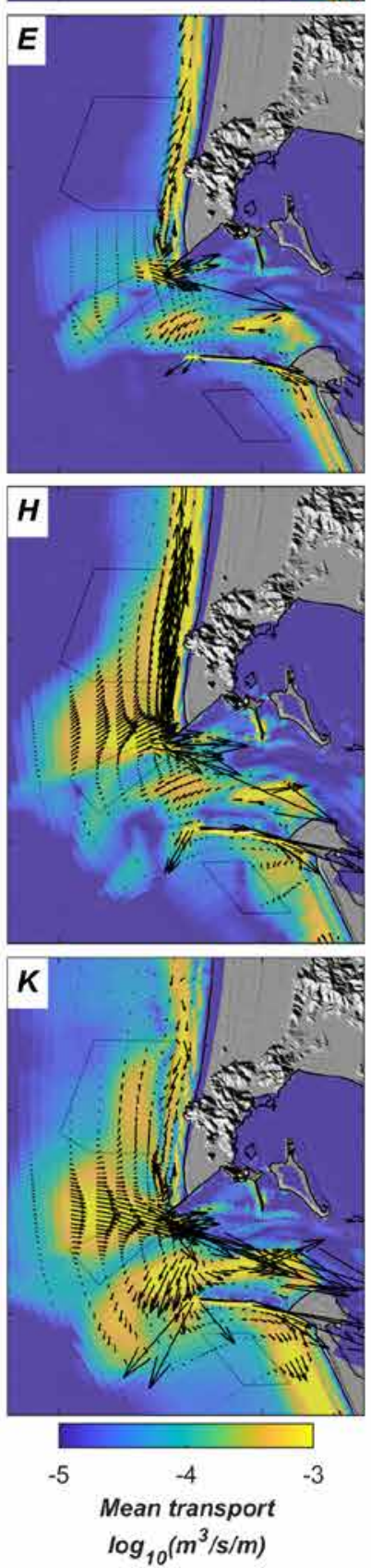
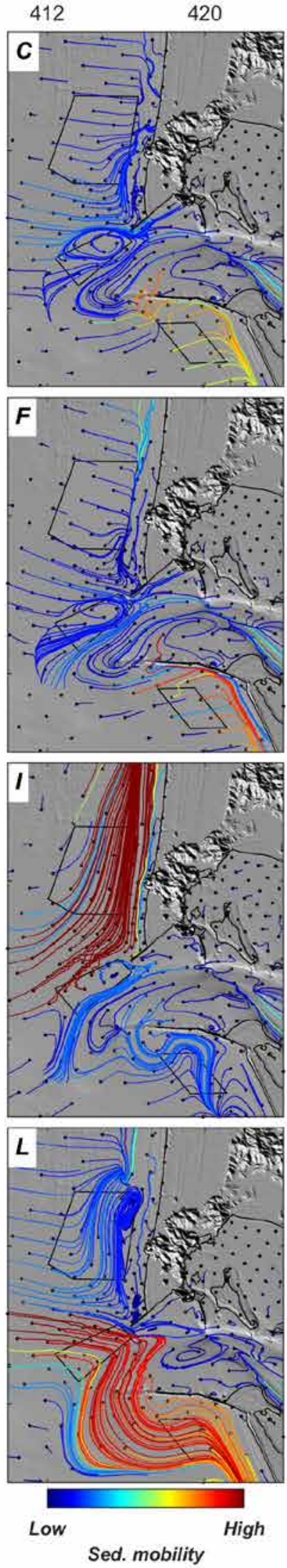

Figure B3. Maps showing modeled wave parameters for wave classes $9(A-C)$, $10(D-F), 11(G-I)$, and 12 $(J-L)$ during low-riverdischarge scenarios (wave classes 9-12 depict winter conditions; see table 5 for wave parameters and probabilities of occurrence for each wave class). Black boxes show locations of dredge-placement sites. $A, D, G, J$ (left panels), significant wave heights; arrows show significant wave height magnitude and peak wave direction. $B, E$, $H, K$ (middle panels), mean total sediment transport; arrows show magnitude and direction of mean total sediment transport (lengths are scaled to length $\left[5 \times 10^{-3}\right.$ $\left.\mathrm{m}^{3} / \mathrm{s} / \mathrm{m}\right]$ of black arrow in upper right corner of $B) . C, F$, $I, L$ (right panels), sedimenttransport pathways (colored lines); black dots indicate initial positions of modeled sediment sources; colors of sediment pathways indicate relative mobility of sources. Abbreviations: km, kilometer(s); m, meter(s); s, second. 


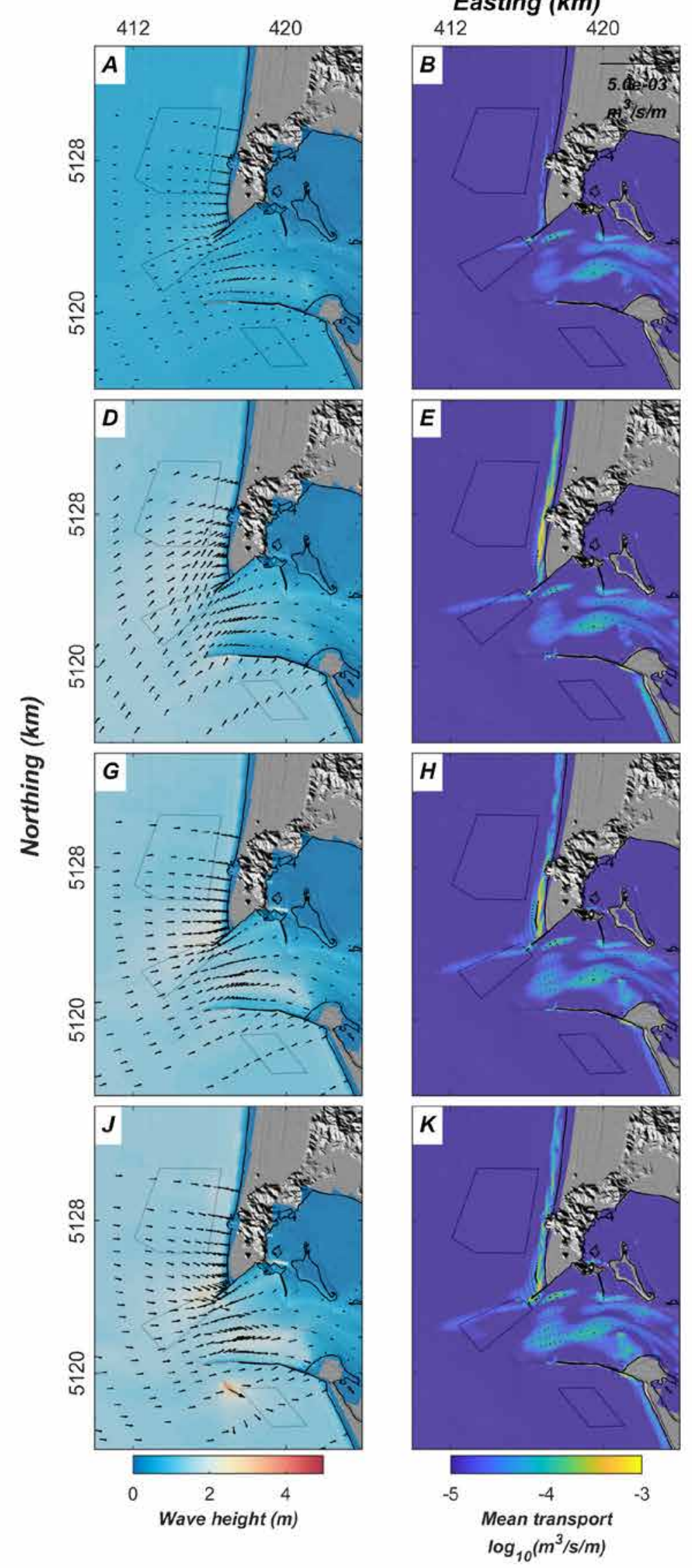

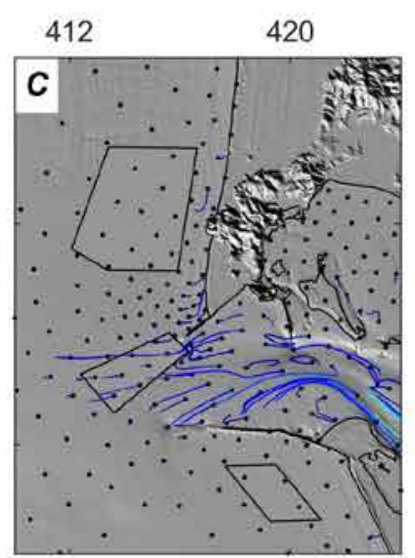
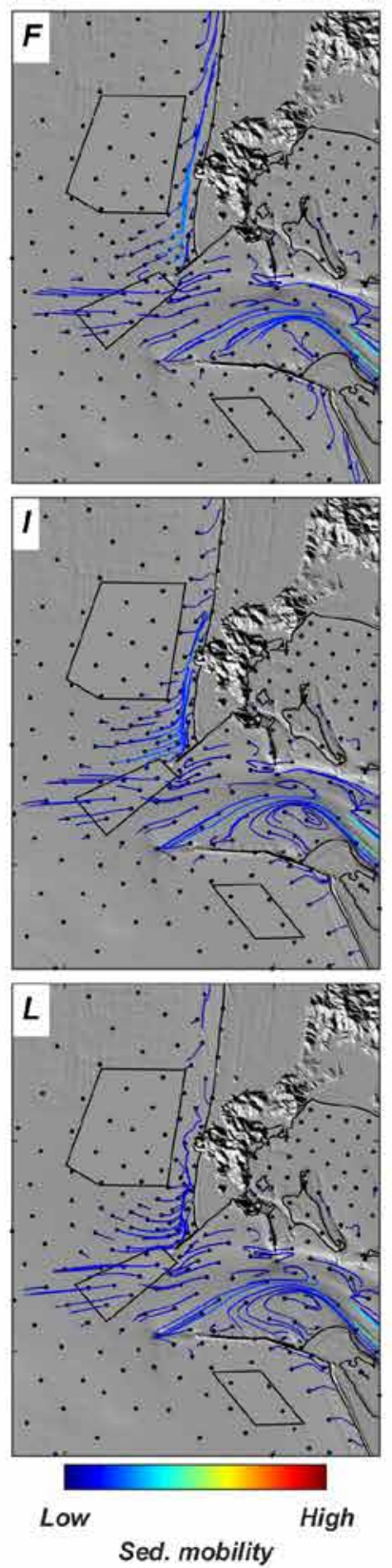

Figure B4. Maps showing modeled wave parameters for wave classes $13(A-C), 14(D-F)$, $15(G-l)$, and $16(J-L)$ during low-river-discharge scenarios (wave classes 13-16 depict summer conditions; see table 5 for wave parameters and probabilities of occurrence for each wave class). Black boxes show locations of dredgeplacement sites. $A, D, G, J$ (left panels), significant wave heights; arrows show significant wave height magnitude and peak wave direction. $B, E, H$, $K$ (middle panels), mean total sediment transport; arrows show magnitude and direction of mean total sediment transport (lengths are scaled to length $\left[5 \times 10^{-3} \mathrm{~m}^{3} / \mathrm{s} / \mathrm{m}\right]$ of black arrow in upper right corner of $B) . C$, $F$, I, L (right panels), sedimenttransport pathways (colored lines); black dots indicate initial positions of modeled sediment sources; colors of sediment pathways indicate relative mobility of sources. Abbreviations: km, kilometer(s); $\mathrm{m}$, meter(s); s, second. 

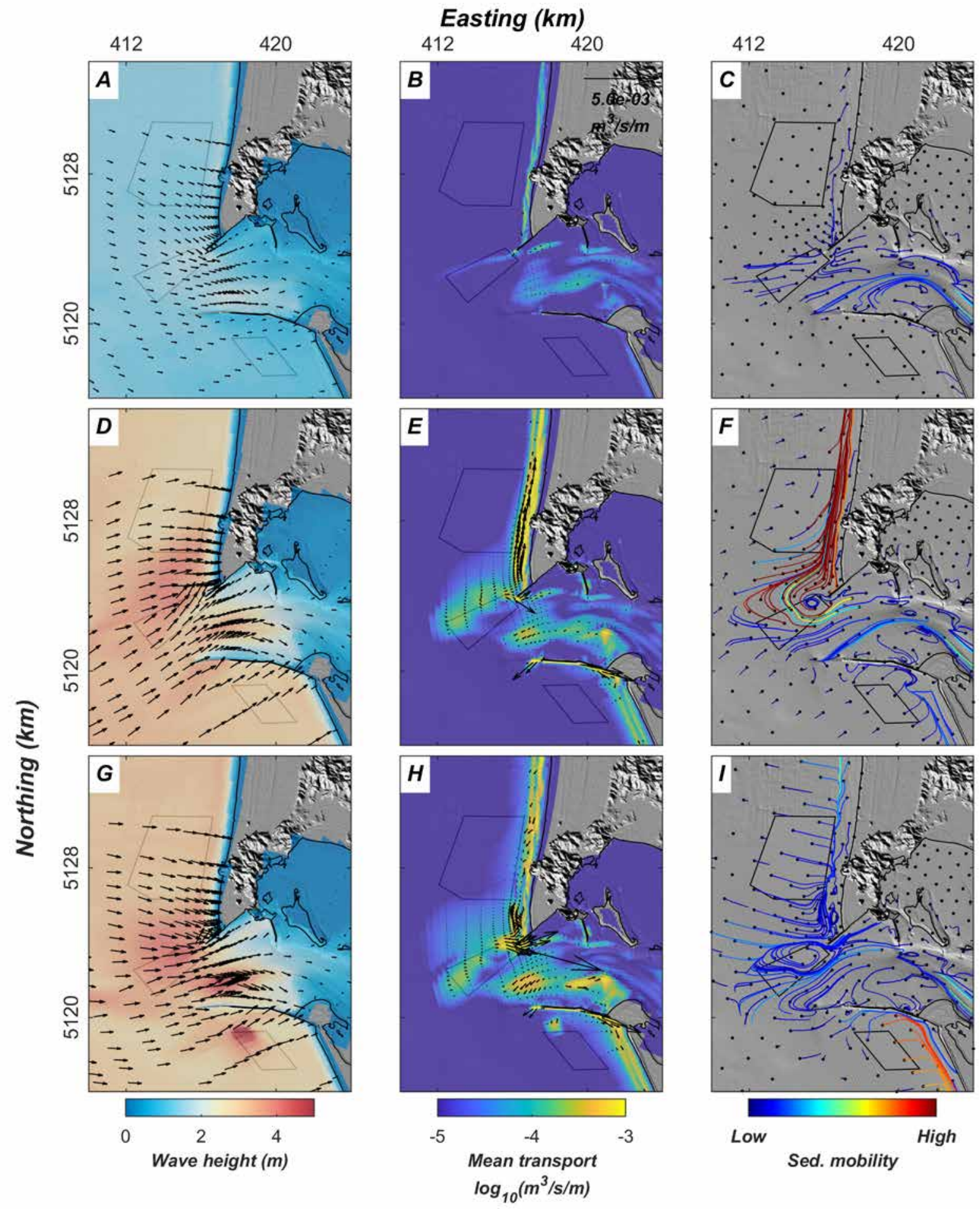

Figure B5. Maps showing modeled wave parameters for wave classes $17(A-C), 18(D-F)$, and $19(G-I)$ during low-river-discharge scenarios (wave classes 17-19 depict summer conditions; see table 5 for wave parameters and probabilities of occurrence for each wave class). Black boxes show locations of dredgeplacement sites. $A, D, G$ (left panels), significant wave heights; arrows show significant wave height magnitude and peak wave direction. $B, E, H$ (middle panels), mean total sediment transport; arrows show magnitude and direction of mean total sediment transport (lengths are scaled to length $\left[5 \times 10^{-3} \mathrm{~m}^{3} / \mathrm{s} / \mathrm{m}\right]$ of black arrow in upper right corner of $B$ ). $C, F, I$ (right panels), sediment-transport pathways (colored lines); black dots indicate initial positions of modeled sediment sources; colors of sediment pathways indicate relative mobility of sources. Abbreviations: km, kilometer(s); m, meter(s); s, second. 


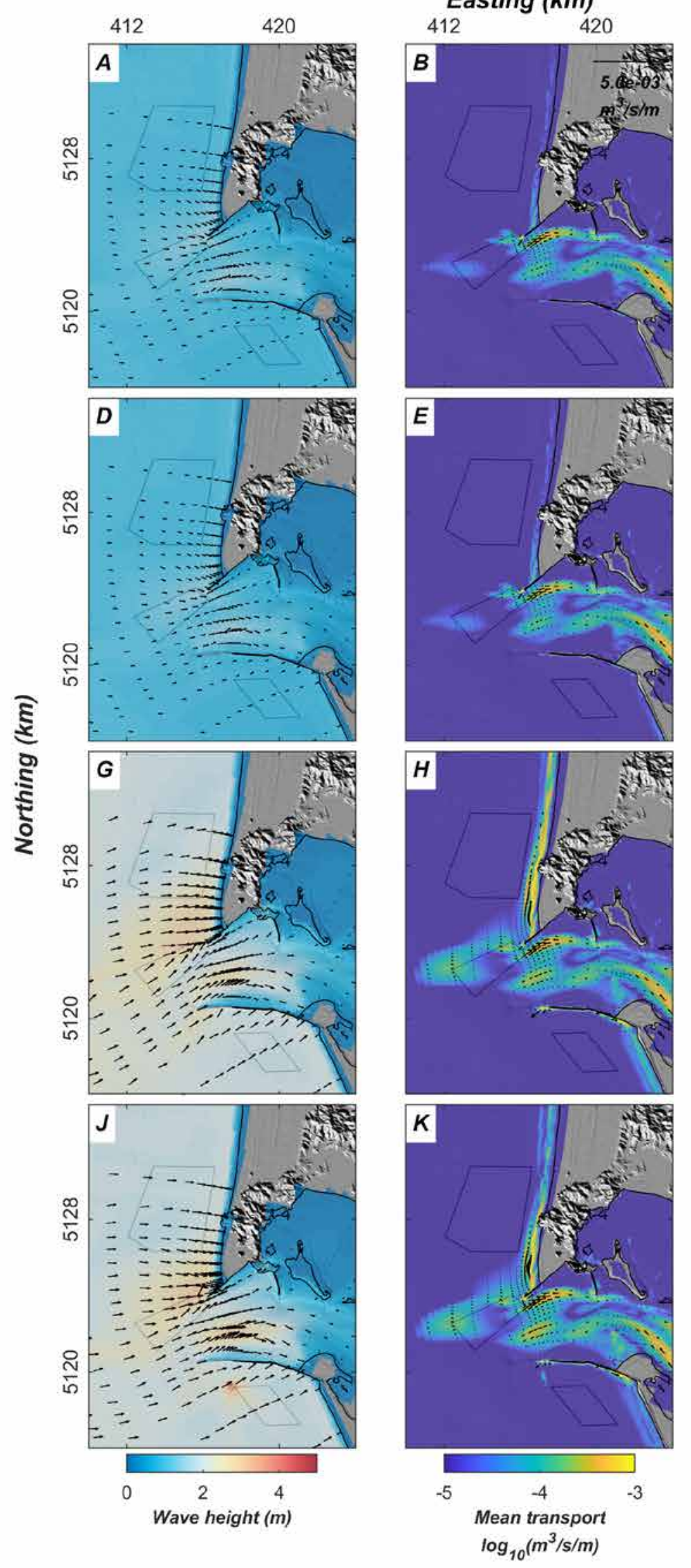

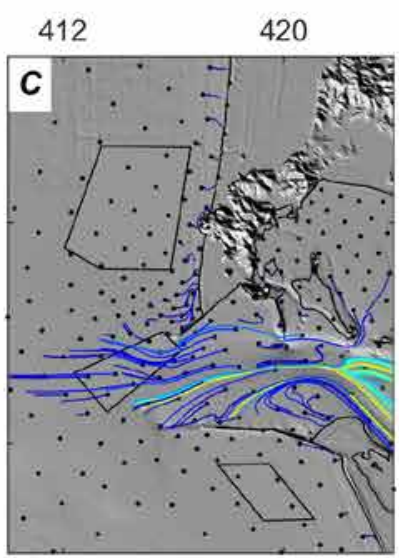
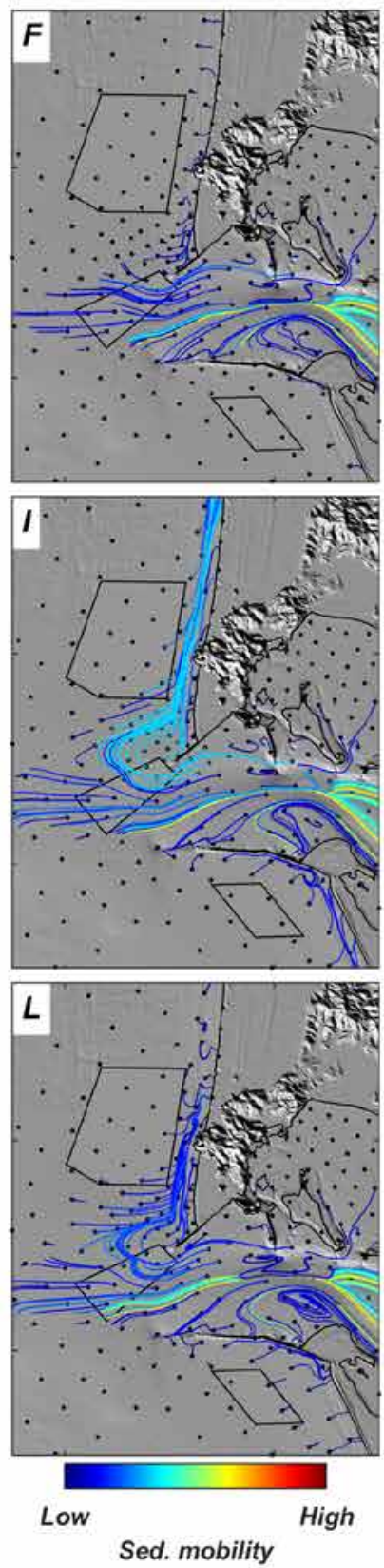

Figure B6. Maps showing modeled wave parameters for wave classes $1(A-C), 2(D-F)$, $3(G-I)$, and $4(J-L)$ during high-river-discharge scenarios (wave classes 1-4 depict winter conditions; see table 5 for wave parameters and probabilities of occurrence for each wave class). Black boxes show locations of dredge-placement sites. $A, D, G$, $J$ (left panels), significant wave heights; arrows show significant wave height magnitude and peak wave direction. $B, E, H$, $K$ (middle panels), mean total sediment transport; arrows show magnitude and direction of mean total sediment transport (lengths are scaled to length $\left[5 \times 10^{-3} \mathrm{~m}^{3} / \mathrm{s} / \mathrm{m}\right]$ of black arrow in upper right corner of $B) . C, F, I, L$ (right panels), sediment-transport pathways (colored lines); black dots indicate initial positions of modeled sediment sources; colors of sediment pathways indicate relative mobility of sources. Abbreviations: km, kilometer(s); m, meter(s); s, second. 

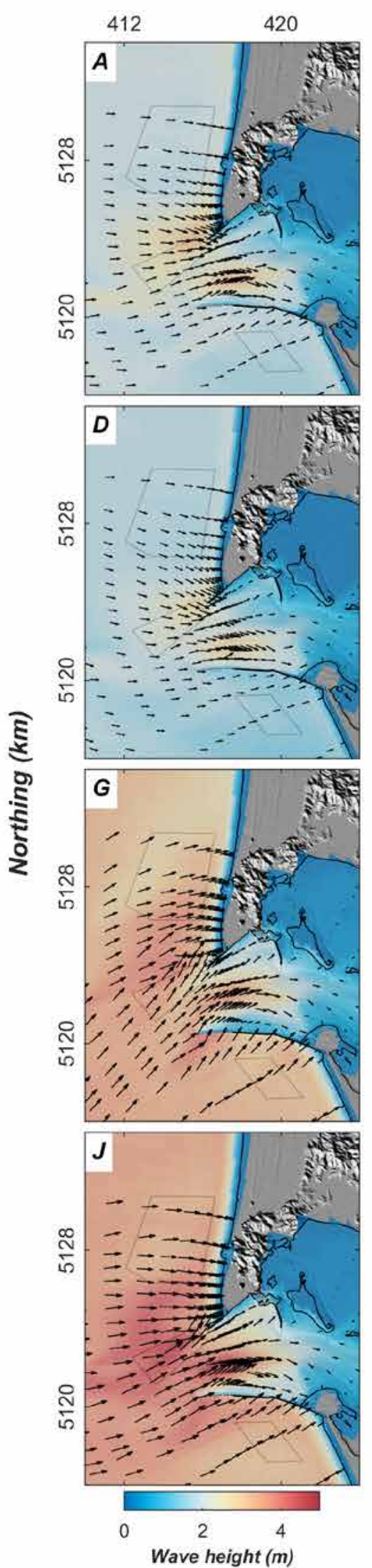
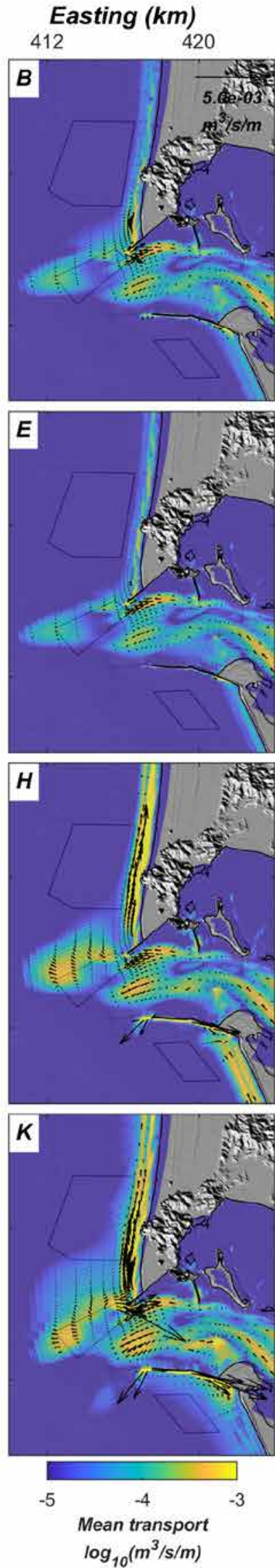
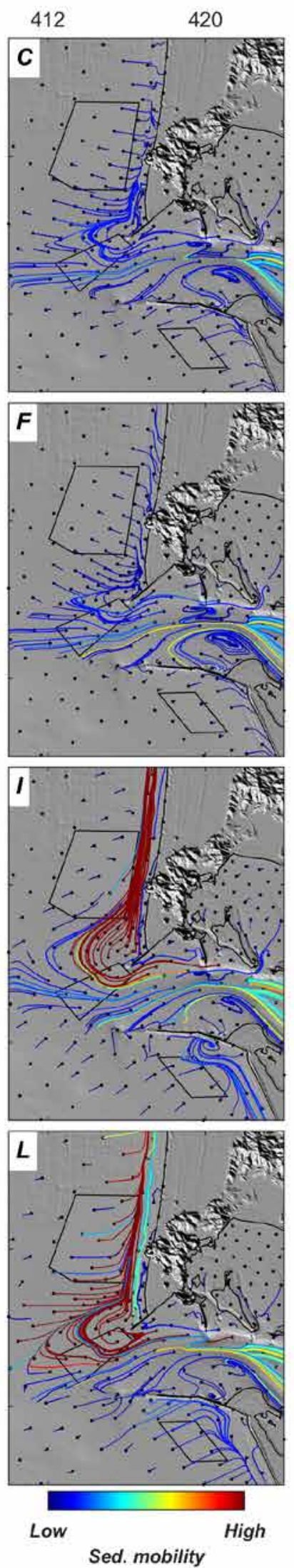

Figure B7. Maps showing modeled wave parameters for wave classes $5(A-C), 6(D-F)$, $7(G-I)$, and $8(J-L)$ during high-river-discharge scenarios (wave classes 5-8 depict winter conditions; see table 5 for wave parameters and probabilities of occurrence for each wave class). Black boxes show locations of dredge-placement sites. $A, D, G, J$ (left panels), significant wave heights; arrows show significant wave height magnitude and peak wave direction. $B, E, H, K$ (middle panels), mean total sediment transport; arrows show magnitude and direction of mean total sediment transport (lengths are scaled to length $\left[5 \times 10^{-3}\right.$ $\left.\mathrm{m}^{3} / \mathrm{s} / \mathrm{m}\right]$ of black arrow in upper right corner of $B$ ). $C, F, I, L$ (right panels), sediment-transport pathways (colored lines); black dots indicate initial positions of modeled sediment sources; colors of sediment pathways indicate relative mobility of sources. Abbreviations km, kilometer(s); m, meter(s); s, second. 


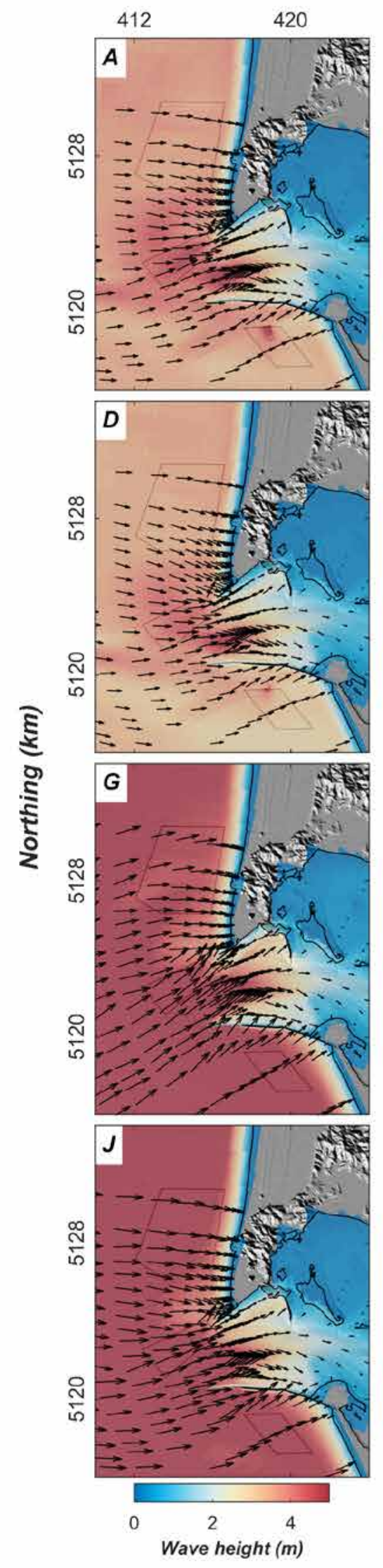

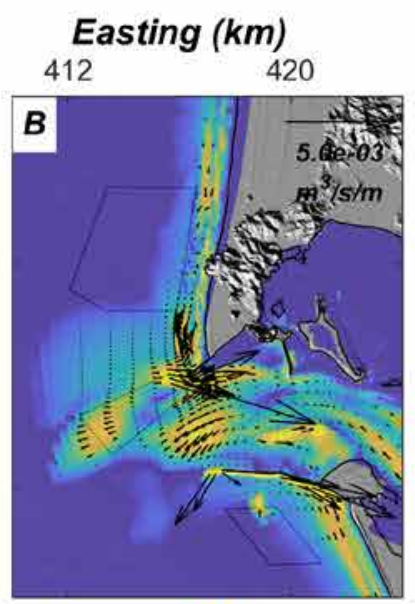
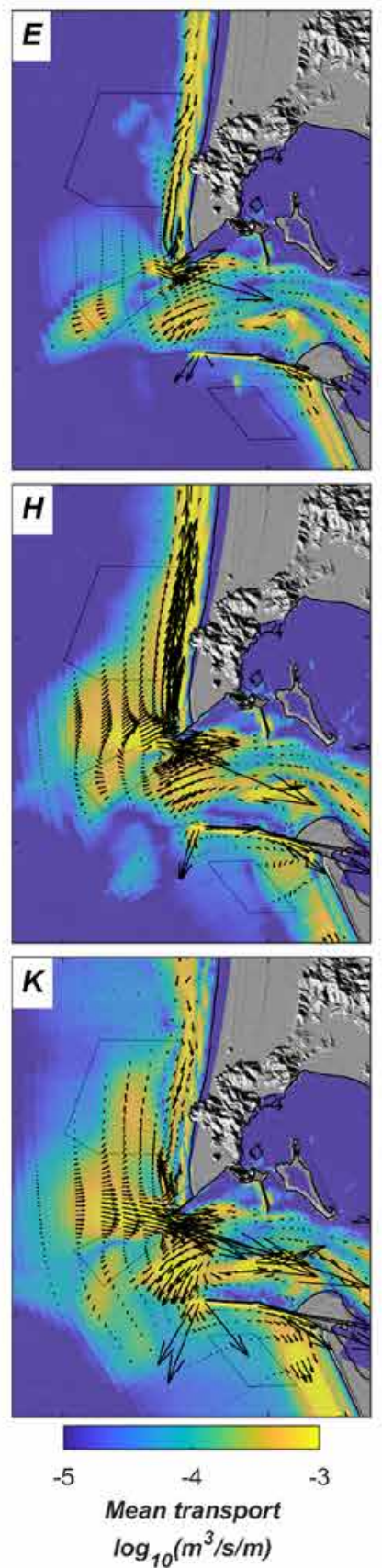
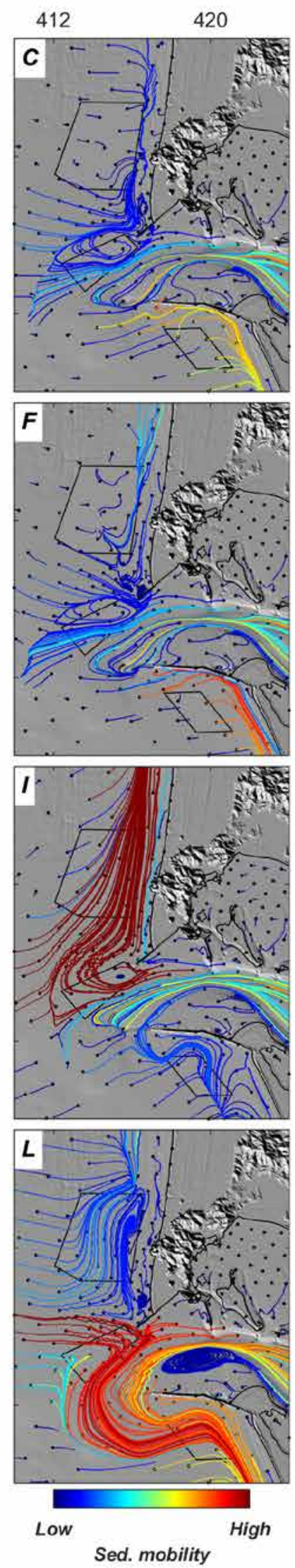

Figure B8. Maps showing modeled wave parameters for wave classes $9(A-C), 10(D-F)$, $11(G-I)$, and 12$)(J-L)$ during high-river-discharge scenarios (wave classes 9-12 depict winter conditions; see table 5 for wave parameters and probabilities of occurrence for each wave class). Black boxes show locations of dredge-placement sites. $A, D$, $G, J$ (left panels), significant wave heights; arrows show significant wave height magnitude and peak wave direction. $B, E, H, K$ (middle panels), mean total sediment transport; arrows show magnitude and direction of mean total sediment transport (lengths are scaled to length $\left[5 \times 10^{-3} \mathrm{~m}^{3} / \mathrm{s} / \mathrm{m}\right]$ of black arrow in upper right corner of $B$ ). $C, F, I, L$ (right panels), sediment-transport pathways (colored lines); black dots indicate initial positions of modeled sediment sources; colors of sediment pathways indicate relative mobility of sources. Abbreviations: km, kilometer(s); m, meter(s); s, second. 

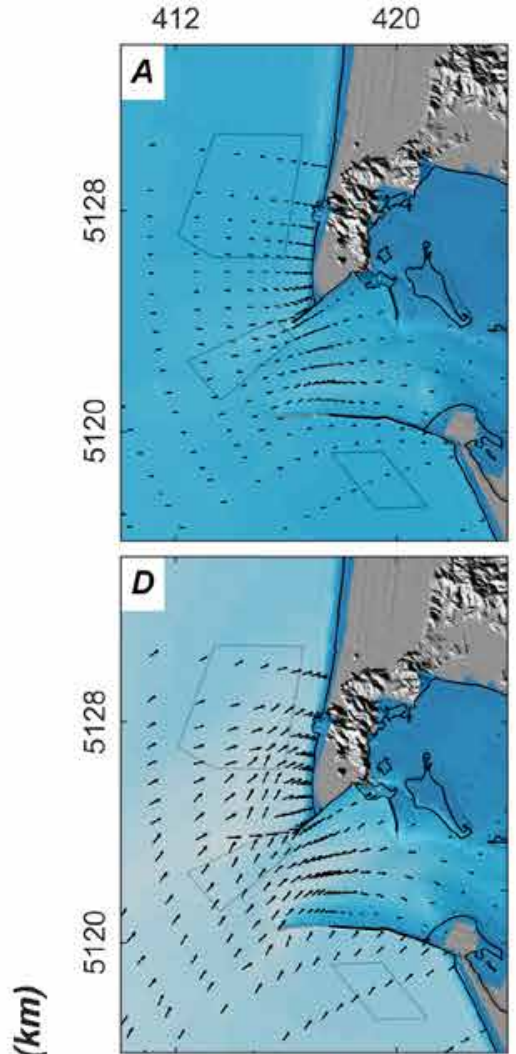

$\frac{5}{2}$
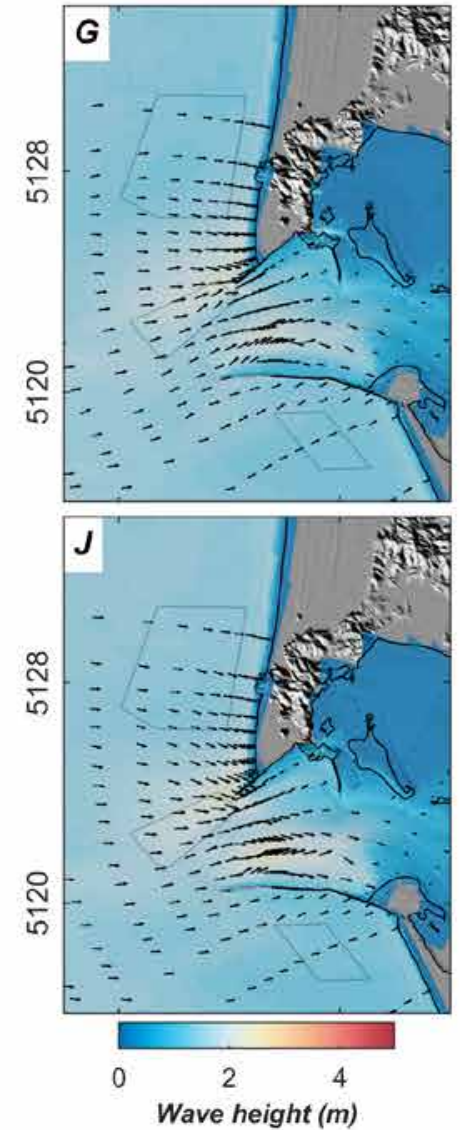

\section{Easting $(\mathrm{km})$}
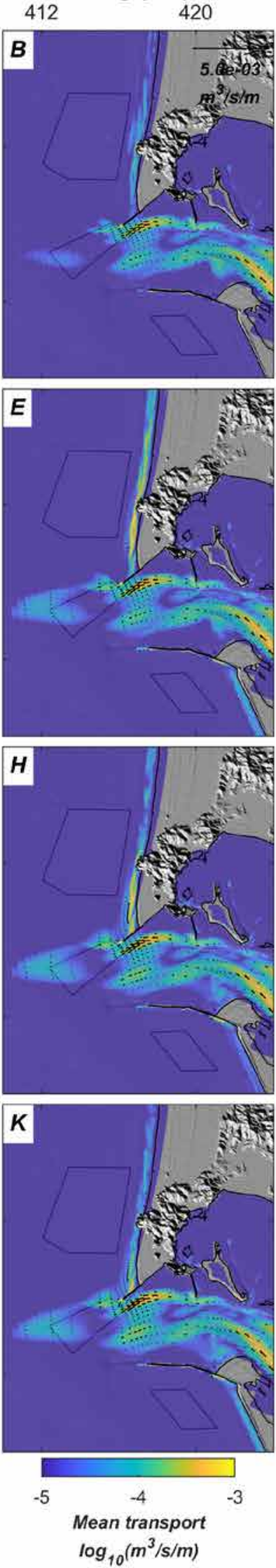
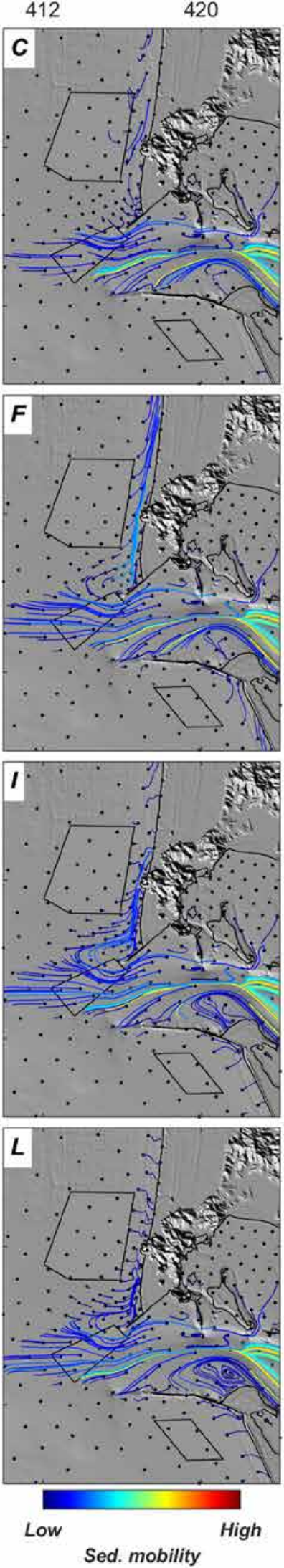

Figure B9. Maps showing modeled wave parameters for wave classes $13(A-C), 14(D-F), 15$ $(G-I)$, and $16(J-L)$ during highriver-discharge scenarios (wave classes 13-16 depict summer conditions; see table 5 for wave parameters and probabilities of occurrence for each wave class). Black boxes show locations of dredge-placement sites. $A, D, G$, $J$ (left panels), significant wave heights; arrows show significant wave height magnitude and peak wave direction. $B, E, H$, $K$ (middle panels), mean total sediment transport; arrows show magnitude and direction of mean total sediment transport (lengths are scaled to length $\left[5 \times 10^{-3} \mathrm{~m}^{3} / \mathrm{s} / \mathrm{m}\right]$ of black arrow in upper right corner of $B) . C, F, I, L$ (right panels), sediment-transport pathways (colored lines); black dots indicate initial positions of modeled sediment sources; colors of sediment pathways indicate relative mobility of sources. Abbreviations: km, kilometer(s); m, meter(s); s, second. 

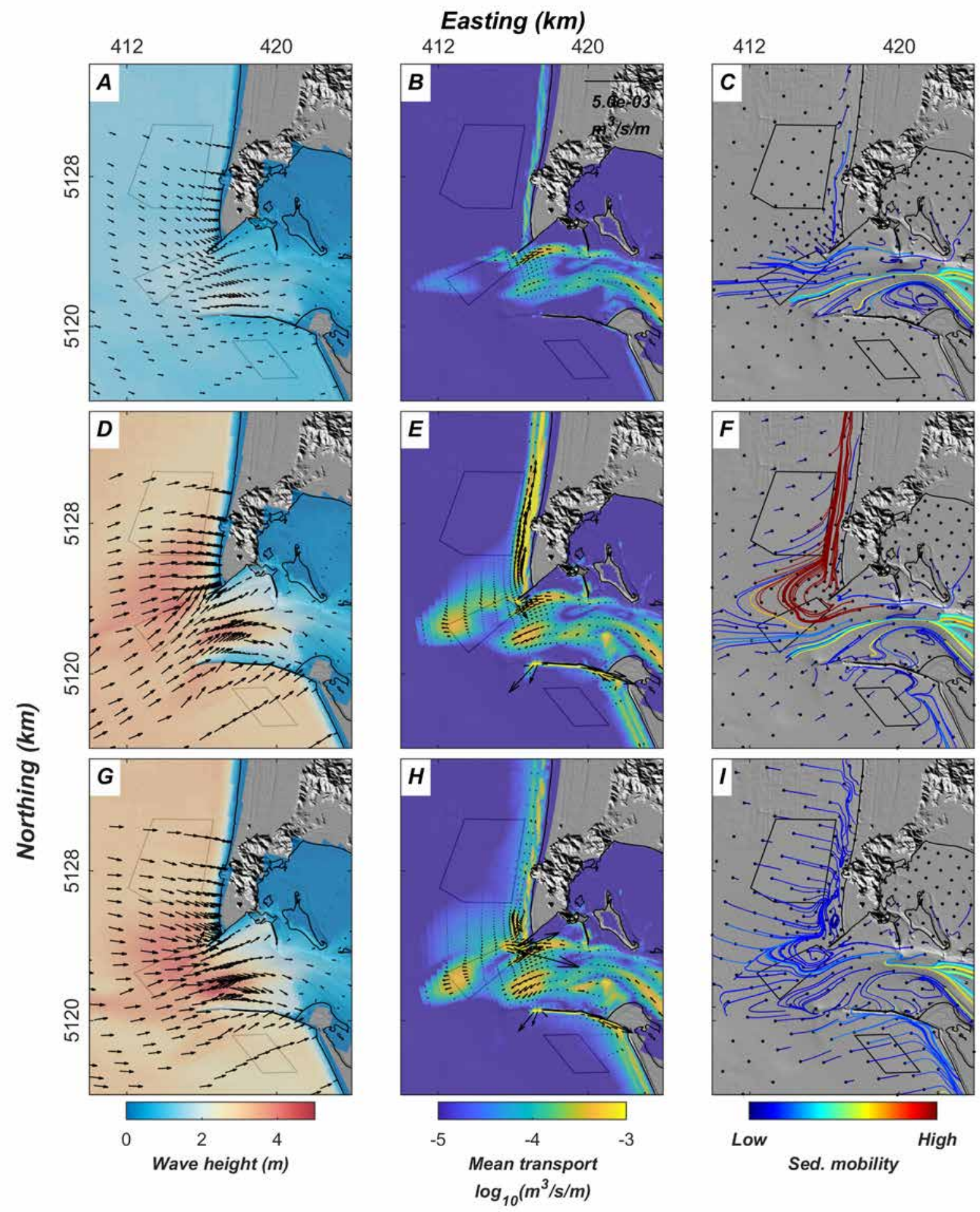

Figure B10. Maps showing modeled wave parameters for wave classes $17(A-C), 18(D-F)$, and $19(G-I)$ during high-river-discharge scenarios (wave classes 17-19 depict summer conditions; see table 5 for wave parameters and probabilities of occurrence for each wave class). Black boxes show locations of dredge-placement sites. $A, D, G$ (left panels), significant wave heights; arrows show significant wave height magnitude and peak wave direction. $B, E, H$ (middle panels), mean total sediment transport; arrows show magnitude and direction of mean total sediment transport (lengths are scaled to length $\left[5 \times 10^{-3} \mathrm{~m}^{3} / \mathrm{s} / \mathrm{m}\right]$ of black arrow in upper right corner of $B$ ). $C, F$, I (right panels), sediment-transport pathways (colored lines); black dots indicate initial positions of modeled sediment sources; colors of sediment pathways indicate relative mobility of sources. Abbreviations: km, kilometer(s); m, meter(s); s, second. 
Menlo Park Publishing Service Center, California

Manuscript approved for publication May 1, 2020

Edited by Taryn A. Lindquist

Layout and design by Kimber Petersen 


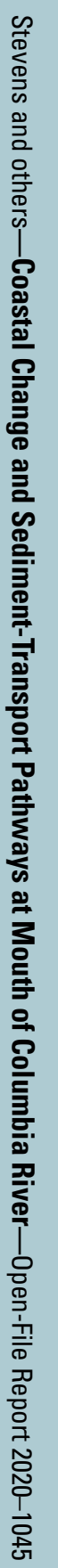

